\title{
WestVirginiaUniversity
}

THE RESEARCH REPOSITORY @ WVU

Graduate Theses, Dissertations, and Problem Reports

2018

\section{Unequal Influence: The Impact of Inequality on Trade Policy}

\author{
Brian William Fitzpatrick \\ West Virginia University, bwfitzpatrick@mix.wvu.edu
}

Follow this and additional works at: https://researchrepository.wvu.edu/etd

Part of the Comparative Politics Commons, and the International Relations Commons

\section{Recommended Citation}

Fitzpatrick, Brian William, "Unequal Influence: The Impact of Inequality on Trade Policy" (2018). Graduate Theses, Dissertations, and Problem Reports. 3738.

https://researchrepository.wvu.edu/etd/3738

This Dissertation is protected by copyright and/or related rights. It has been brought to you by the The Research Repository @ WVU with permission from the rights-holder(s). You are free to use this Dissertation in any way that is permitted by the copyright and related rights legislation that applies to your use. For other uses you must obtain permission from the rights-holder(s) directly, unless additional rights are indicated by a Creative Commons license in the record and/ or on the work itself. This Dissertation has been accepted for inclusion in WVU Graduate Theses, Dissertations, and Problem Reports collection by an authorized administrator of The Research Repository @ WVU.

For more information, please contact researchrepository@mail.wvu.edu. 
Unequal Influence: The Impact of Inequality on Trade Policy

\title{
Brian Fitzpatrick
}

Dissertation submitted to the Eberly College of Arts and Sciences at West Virginia University in partial fulfillment of the requirements for the degree of Doctorate of Philosophy in Political Science

\author{
Christina Fattore, Ph.D., Chair \\ Robert D. Duval, Ph.D. \\ David M. Hauser, Ph.D. \\ Matthew Jacobsmeier, Ph.D. \\ Philip A. Michelbach, Ph.D.
}

Morgantown, West Virginia 2018

Keywords: Representation, Trade, Inequality, Interest Groups, International Political Economy, Class, United States, Latin America

Copyright 2018 Brian Fitzpatrick 


\title{
ABSTRACT \\ Unequal Influence: The Impact of Inequality on Trade Policy
}

\author{
Brian Fitzpatrick
}

Trade was a central issue in the 2016 US presidential election, with both major party candidates debating how trade impacts American workers. However, the current literature on trade policy outcomes and inequality has insufficient measures of public opinion on trade. I examine the varying roles the public and interest groups play in the trade policy formation process as inequality changes in democratic societies. I expect, as inequality increases, the public and mass based interest groups will have less resources to expend on influencing policymakers. Also, as inequality increases economic elites' and business interest groups' resources will increase, and they will use these increased resources to take advantage of this gap in influence left by the public and mass based interest groups, to increasingly control policy. To test this theory, I examine the influence public opinion and interest groups have on trade agreement support among US senators and trade openness in Latin American States. The results are mixed, interest groups in favor of trade and against trade have influence over trade policy in the United States at all levels of inequality, while in Latin America the public views groups in favor of trade as becoming more powerful as inequality increases, and groups against trade becoming less powerful. In both cases, the results for the public point to the middle class, and not the upper class, having the most influence over policy, while those at the bottom have no influence. 


\section{Acknowledgements}

Not one is able to complete a $\mathrm{PhD}$ on their own, I wish to thank the following people for their support and assistance. First my parents, Karin and Martin Fitzpatrick, for their support throughout this process and for giving me the tools needed to be successful in my career. My advisor and dissertation chair, Christina Fattore, provided constant assistance and help, and always provided the gentle nudges needed to make sure I would finish. I would also like to thank the members of my dissertation committee, David M. Hauser, Matthew Jacobsmeier, Philip A. Michelbach, and Robert D. Duval, whose feedback and comments significantly improved the quality of this document. My graduate student colleges at WVU were also a great source of help and support, particularly Coty Martin and Michael Thunberg who provided comments on early drafts of chapters, and my writing group friends and colleges Franchesca Nestor and Lauren Santoro who provided useful feedback and constant support throughout this process. I would also like to thank Lauren Reed who assisted with late stage edits, greatly improving the overall quality of writing. I wish to express my sincerest appreciation to my undergraduate advisor, Linda Cornett, who was the person who originally sparked my interest in political economy. Also, thank you to my colleagues at West Liberty University who were very supportive as I finished writing my dissertation and prepared for my defense. Finally, I would like to thank Maude. 


\section{Table of Contents}

Chapter 1 Introduction: Rising Inequality and the Public Feeling Unrepresented...............1

Chapter 2 Literature Review: The Relationship of Inequality, Class, Interest Groups, and

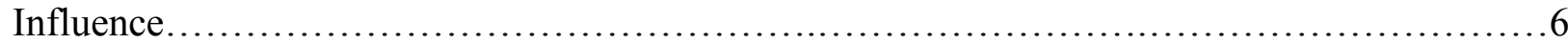

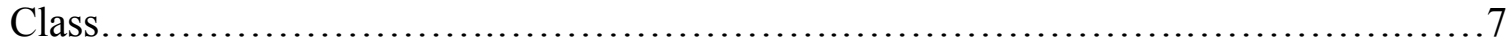

Social Networks and Class...................................................... 7

Income, Skill, Political Participation, and Inequality in Representation..................15

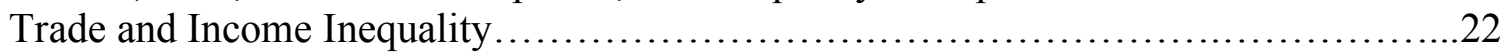

Trade Policy: Individual Preferences Disconnected from Policy Outcomes..............23

Variation in Interest Groups.................................................... 27

Interest Group Influence on Trade Policy....................................... 35

Chapter 3 A Theory of Inequality and the Unequal Influence of the Public and Interest

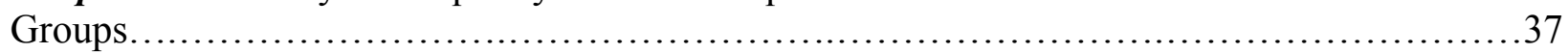

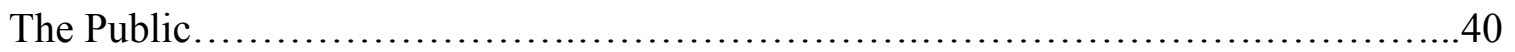

Determining Who is in What Category......................................... 41

Capabilities that Determine Class.......................................43

Income and Preferences...................................................46

Economic Elites......................................................47

Mass Public: Low-Income, Middle-Income, and High-Middle Income..........49

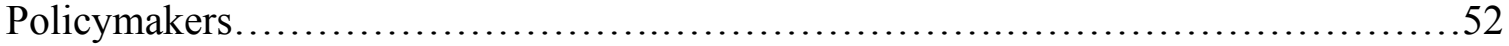

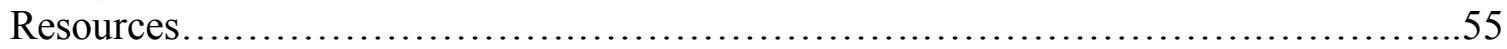

Resources Changing with Inequality........................................57

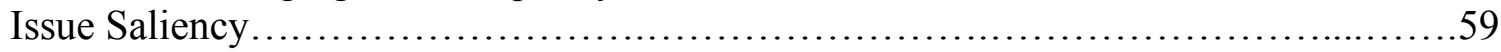

Trade Policy Saliency................................................62

State Level Variation........................................................... 63

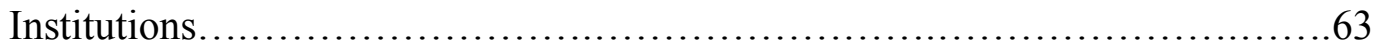

Mature versus Transitional Democracies.................................66 65

Inequality and Regional Variation: Case Selection................................67

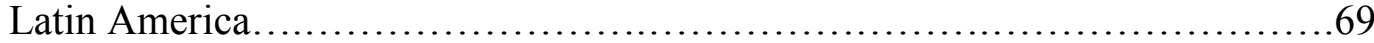

United States.......................................................... 72

Chapter 4 The Impact of Inequality on Support for Preferential Trading Agreements in the

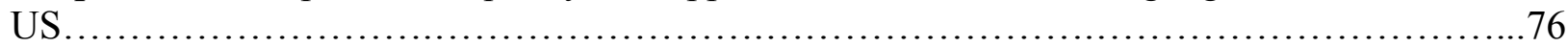

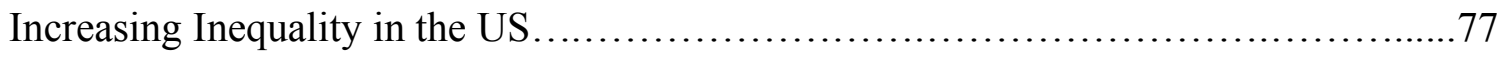

Hypotheses................................................................... 78

Research Design........................................................... 84

Dependent Variable................................................. 85

Independent Variables.................................................. 86

Control Variables....................................................93

Results....................................................................... 95

Discussion and Conclusion...105

Chapter 5 The Influence of the Public and Interest Groups on Latin American Trade

Openness....................................................................... 137

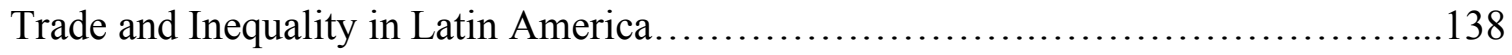

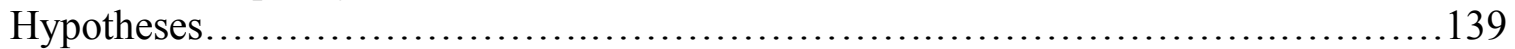

Data and Methods............................................................... 140 
Dependent Variable: Trade Openness.................................. 141

Independent Variables................................................. 142

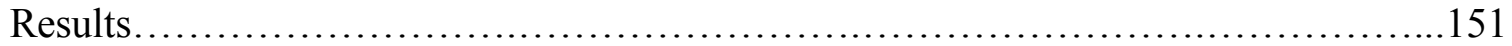

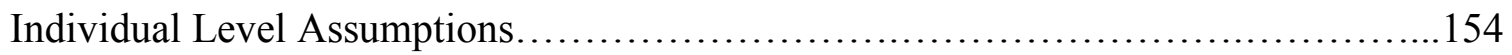

Discussion and Conclusion.................................................... 165

Chapter 6 Conclusion: Expanding the Scope....................................... 198 


\section{Chapter 1}

\section{Introduction: Rising Inequality and the Public Feeling Unrepresented}

With the refrain of, "drain the swamp" during the 2016 US presidential election, then candidate Donald Trump was able to tap into the feelings of many American's that the government does not represent their interests. On the left, candidate Bernie Sanders was able to draw on similar sentiments, making the idea that the US is governed for the wealthy and special interests a central theme of his campaign. Most Americans, 69 percent, say the majority of members of Congress are focused on the needs of special interests, while 25 percent say Congress is focused on the needs of their constituents (Dugan 2015). This is similar to the sentiments of Latin Americans: across Latin American countries 77.2 percent say their country is governed for the benefit of a few powerful groups, while only 22.8 percent say their country is governed for the benefit of everyone. ${ }^{1}$ Assuming that the people want everyone to benefit from the government's policies, the public does not feel like the government is passing policies that represent what the people want.

Not only do people view government as much more responsive to special interests, and largely ignoring the needs of their constituents, but the majority also believe the wealth distribution is unfair. In the United States only 31 percent of Americans see the wealth distribution as fair (Newport 2015), while only 21.6 percent of those across Latin American countries say the income distribution is fair or very fair. ${ }^{2}$ These numbers are no surprise given that inequality in most regions of the world has increased in the past few decades (Alvaredo, et

\footnotetext{
${ }^{1}$ From the 2016 Latinobarometer, responding to the questions, "Generally speaking, would you say that (country) is governed for a few powerful groups in their own interests? Or is it governed for the good of all?" The 2016 Latinobarometer includes respondents from Argentina, Bolivia, Brazil, Chile, Colombia, Costa Rica, Dominican Republic, Ecuador, El Salvador, Guatemala, Honduras, Mexico, Nicaragua, Panama, Paraguay, Peru, Uruguay, Venezuela.

${ }^{2}$ From the 2016 Latinobarometer, responding to the question, "How fair do you think the income distribution is in (country)?"
} 
al. 2018). It follows that if people believe the wealth or income distribution in their country is not fair, they would feel the government is not representing them and is instead representing the interests of already privileged groups. How accurate would these feelings be? Are people's feeling about politicians not representing their constituents' interests and instead representing the concerns of special interest groups accurate? Are politicians representing the interests of some constituents while ignoring the interests of the majority, making the majority of the population believe constituents are not represented? This dissertation explores the connection between inequality and representation, both representation of the public and representation of interest groups.

Solt (2008) finds that as inequality increases political participation declines, except among the wealthiest citizens. Politicians need financial resources to run their campaigns, therefore as economic inequality increases, they will increasingly focus their attention on the interests of the wealthy who are politically engaged and have resources to expend supporting their chosen candidate. At the same time, the poor and middle class will become less engaged, lowering their influence over policy outcomes. This is because politicians have little incentive to adopt the preferences of voters who are not engaged. Overall, this means constituents will become less engaged in politics. With constituents less engaged, politicians have more leeway to adopt the preferences of interest groups who are able to provide resources to politicians to help with their reelection. When there is low economic inequality, the public will be more engaged, and therefore will have greater influence over policy, while interest groups will have less influence.

To test this theory, I examine how the public's and interest groups' preferences are expressed through trade policy. While I expect this theory to apply beyond trade policy to other 
issues, I use trade policy to explore this theory for two reasons. First, the effects of trade policy are wide spread. Businesses, workers, and consumers are all affected by trade policy, from the price of raw materials for manufacturers, to workers facing increased competition, to the availability and price of products to consumers. This gives business interest groups, labor groups, and the public a stake in trade policy and therefore an incentive to want to influence trade policy. Second, trade policy has both positive and negative impacts, and importantly, these impacts will vary across skill levels within a society. This gives individuals within a country at different skill levels varied opinions on trade because they are affected differently by trade. As will be explained in the substantive chapters, high-skilled and low-skilled workers will have different incentives to be for and against trade. This helps to ensure that workers at different skill levels and, in turn, different income levels, will have varying opinions on trade. These varying opinions on trade are important in determining what impact the opinion of each group within the public has on trade. If the opinion of all classes in society varied in a similar way on trade policy, then who had what impact on trade would be much more difficult to determine.

Previous work has examined the effect of inequality on trade policy, as well as predicting individuals' trade opinions. ${ }^{3}$ However, such work failed to examine the connection between actual public opinion on trade policy and how this affects trade policy outcomes in the light of inequality. The focus of this project is to determine what influence public preferences have on trade policy, what influence interest groups have on trade policy, and to determine how the public's and interest groups' influence is affected by inequality. Specifically, I ask the question, what role does economic inequality play in the level of influence the public and interest groups have on trade policy outcomes?

\footnotetext{
${ }^{3}$ See Dutt and Mitra (2002), and Mayda and Rodrik (2005).
} 
I expect my theory to apply across democratic states; the two cases I use to examine my theory are the US and Latin America. The US and Latin America were chosen for several reasons. The US is a democracy, as are Latin American countries, with some exceptions. Next, I wanted to examine trade policy formation within a country as well as across a group of countries. The internal workings of a country are examined to determine the effects of inequality on legislators' actions, and multiple countries are examined in the same analysis to determine how the theory applies across states. Since the US Senate must ratify trade agreements, this allowed for me to determine what impact inequality within US states has on trade policy. Importantly, the US case also provides a case where the interest group system is highly developed. Latin America allows me to look at trade policy formation across several countries, and across time. Latin America also offers an example where the interest group system is still developing. This provides some methodological challenges, but also lets me examine how my theory applies across different interest group systems. Additionally, data at the individual level is available for Latin America, which allows me to explore the individual level assumptions of my theory.

For both the US case and the Latin American case I find evidence that, contrary to my expectations, it seems to be the opinion of the middle class that has the most influence on trade policy. This appears to be the case at all levels of inequality. Interestingly, the US case points to business interest groups having less influence at higher levels of inequality, the opposite from what was expected, and unions having more influence at higher levels of inequality, again the opposite from what was expected. Business interest groups were expected to have greater influence at higher levels of inequality, while unions were expected to have less. These results are consistent with the individual level findings from the Latin American chapter that examine 
how participation changes with inequality. While, as expected, political participation across several categories declines with inequality, for those in the lowest SES group in Latin America relative participation in unions actually increases. This could point to those at the bottom actually participating more in some ways as inequality increases, possibly as a way to mitigate the effects of increased inequality.

This project is a start to investigating the interaction between inequality and the influence of the public's and interest groups' preferences on policy outcomes and leaves much work to be done. As will be discussed in the conclusion, how the saliency of policy effects influence by different socioeconomic groups and how my theory applies across issues are future avenues of research. 


\section{Chapter 2}

\section{Literature Review: The Relationship of Inequality, Class, Interest Groups, and Influence}

As Moravcsik (1997) explains, representative institutions are the way the preferences of individuals and groups within society influence policy and, "Government policy is therefore constrained by the underlying identities, interest, and power of individuals and groups (inside and outside the state apparatus) who constantly pressure the central decision makers to pursue policies consistent with their preferences" (518). Those in society with power will be the ones policy makers have an incentive to represent.

I argue economic inequality leads to inequality in representation. When I am discussing inequality, I am talking about economic inequality, that is, the distribution of wealth among individuals within a given area. That an unequal society leads to unequal representation is not a novel idea, several authors (Bartels 2008; Gilens 2005; Gilens and Page 2014; Hacker and Pierson 2010; Winters and Page 2009) have examined how economic inequality leads to inequality in representation. I build on their work by adding in the interaction between the public, interest groups, and inequality, adding a more nuanced view of how class stratification in the public contributes to inequality in representation, and examining what influence public opinion has on policy formation at different levels of inequality.

Changing inequality is fundamentally linked to changing class, and class is related to more than just wealth, making it necessary to explore how class impacts representation. Therefore, first an exploration of how class is defined is necessary in order to determine how class impacts representation. 


\section{Class}

The concept of class is often vague and too reliant on economic situation. As Eisenhauer (2008) says when discussing how to define the middle class, there is a poverty line in the US but there is no line that defines the middle class despite politicians constantly discussing and making appeals to the "middle class." Other countries also have poverty lines, and organizations such as the World Bank have definitions of poverty and extreme poverty, but not one of middle class, or upper class for that matter. Eisenhauer goes on to give an income-based definition of the middle class and the wealthy, as other authors have done (see Burkhauser 1996; Cashell 2007; Kapsos and Bourmpoula 2013). These measures are income-based, which are useful in some cases, but ultimately fall short when trying to determine the class-based political capabilities of an individual. When measuring the ability to influence politics, a much more expansive definition of class and what it means to be in a given class is needed. When thinking about class as it relates to influencing political outcomes, everything from income, education, and, importantly, social networks become relevant. I begin by examining the literature on how social networks effect class to determine individual capabilities and willingness to influence policy, and the responsiveness of policy makers to their preferences. Then I examine how other factors, particularly income and wealth, effect a person's ability to participate.

\section{Social Networks and Class}

Lax and Phillips (2012) find that state-level policy in the US only follows the preferences of the majority about half the time. They argue when an issue is salient to voters that policymakers are more responsive to public opinion, but policy makers are also overresponsive to ideological concerns. While Broockman and Skovron (2014) find politicians generally have misperceptions of what their constituents' policy preferences actually are, believing constituents 
hold more conservative views than they actually do on salient issues such as healthcare and same-sex marriage. This conservative bias could be explained by the social networks that politicians belong to; if a politician is constantly hearing from those around them support for a more conservative position it is likely that they will adopt this more conservative position, or whatever the dominant position is of the network they belong to. As Carnes (2012) finds, politicians tend to represent the interests of the class they come from, therefore policy outcomes are likely biased towards the preferences of the class where politicians predominantly come from, the upper class. Elected officials at the national level are political elites and therefore, as will be discussed, tend to belong to networks with other elites, both political elites and elites in the private sector.

Khan (2012) writes there are two schools of thought on what elites are, "a kind of Weberian definition of class, generally think of elites relative to the power and resources they possess, and others who, following a more Marxist line of thought, think of elites as those who occupy a dominant position in social relations" (362). Kahn draws from both of these definitions to define elites as, "those who have vastly disproportionate control over or access to a resource" (362). When I am talking about economic elites, who are not necessarily political elites, I am talking about those who have disproportionate access to representation; they are able to have outsized influence over policy, but how does this outsized policy influence occur? A partial answer comes from networks formed among political elites and elites within society.

Class starts to form at an early age simply by who one's parents are. Lareau (1987) finds that parents who are poorly educated and earn a low income are less likely to be involved in their children's school activities or help them at home with schoolwork. These parents feel their lack of education makes them less able to help their children, and therefore they leave education up to 
the school. Meanwhile, parents who are more affluent and college educated become more involved with activities at their children's school and help them more at home with schoolwork, viewing their children's education as a partnership between themselves and the school.

Furthermore, more affluent middle and upper class parents network and socialize with other parents at school, building networks that give them information about how well their children are performing, while low-income parents tend not to do this (Lareau 1987). Therefore, the children of middle and upper parents have a ready built network that can help them later on, for example with employment. This is reflected by individuals who come from an upper class background having more success climbing the corporate ladder because of the social capital they have through a ready network of friends and relatives who are in high-status positions, giving them a leg up (Useem and Karabel 1986). Social capital is a resource that is gained through interaction with others and is the relationships between actors that can be used to influence the actions of others (Coleman 1988). As with other forums of capital, social capital is used for production, in this case to get someone to do something. For example, someone could use their social capital to help find them a job. Fundamentally, social capital is the social relationships we have that can be exploited to benefit our own interests (Putnam 2000).

Education also plays a role in class, but not all institutions are equal. A degree from a top ranked university helps with career advancement more than a degree that is not from a top school, however, those who attend top ranked institutions and are from the upper class are the most successful (Useem and Karabel 1986). Therefore, even if a person obtains a degree from a top university, if they do not have the elite background they are not as likely to join an elite network. These elite networks are important because once people are in management they tend to form similar political opinions. By examining the ties between those on corporate boards and 
their political behavior, Burris (2005) finds being on corporate boards helps to form political cohesion among elites. This interaction also occurs beyond corporate boards in other public and private institutions, helping to create a shared political view among elites (Heinz et al. 1990).

There is evidence these networks stretch across the public and private spheres.

Moore (1979) found evidence of the existence of a national elite network in the United States made up of elites in the public and private sectors. Moore questioned people in top positions in various governmental and nongovernmental institutions and found those within these institutions regularly interacted with others in top positions in other institutions, forming a network spanning the public and private sector. ${ }^{4}$ Individuals within this network also identified others within the network as influencing the decisions of those within this elite network, those in the top positions in the private and public sector were regularly interacting with one another and asserting influence on one another. ${ }^{5}$ There is also a racial aspect to elite networks. Minorities in managerial positions tend to form fewer ties with others in managerial positions; additionally, the ties minorities form are not as strong, and the ties minorities form are seen by themselves as less useful for career advancement (Ibarra 1995). If elite networks influence the policy preferences of politicians, this can help to explain why minorities have a harder time climbing the class ladder and therefore why they will have less chance to intermingle with and influence political elites.

Above I discuss evidence supporting that those in elite networks form similar opinions, as well as the formation and existence of these elite networks. Next, I discuss non-elite networks.

\footnotetext{
${ }^{4}$ Moore questioned people in the top positions in ten different US institutions, Congress, Federal Administration Political Appointees, Civil Service, Industrial Corporations, Nonindustrial Corporations, Holders of Large Fortunes, Labor Unions, Political Parties, Voluntary Organizations, and the Media.

${ }^{5}$ These Elite Networks are not limited to the US or the national level. Edling, Farkas, and Rydgren (2015) find networks exist between the political elite and the elite in the public sector in Swedish towns.
} 
People in different classes interact somewhat differently, as was briefly discussed regarding parent participation in their children's education (Khan 2012). People in high and low-socioeconomic groups are as likely to exchange social favors with one another, but a typical exchange for those in the low SES category consist of exchanges of meals between parents and childcare, and are generally between neighbors or relatives (Muir and Weinstein 1962). Exchanges between those in high SES groups involve things like transportation, meals in the form of dining out or dinner parties, and leisure social activities, and these exchanges are more likely to be with friends and acquaintances. Thus, those in the low group engage in more practical, less social activities, while those in the higher group are more likely to have exchanges in terms of social activities. These greater social interactions give greater opportunity for the discussion of politics. When people who are in a social network discuss politics with at least one other person in that network they are more likely to become involved in politics, with larger networks generally meaning more participation (Knoke 1990; Leighley 1990; McClurg 2003). What the diversity of political views is in a network can also affect participation.

Those within networks where some people agree with their views and some are opposed are the most likely to vote, while those in networks where their views are mostly challenged are the least likely to vote, and those who are in networks that are supportive of their views are moderately likely to vote (Nir 2011). However, there is somewhat contrary evidence that different political opinions within a network serves to lessen political participation, while similar political opinions increase participation (Mutz 2002; Scheufele et al. 2004). No matter what the case is, diverse networks do lead to people being more informed; those in networks with people who have different opinions are more likely to be informed about current political issues (Richey 2008), and they seek out information because they know their views will be challenged (Eveland 
2004). These networks are likely to have people who will be the most difficult for politicians to persuade to go against their preferences because they are the most informed. However, in general, people discuss politics with people they agree with and will avoid discussing politics with those they disagree with (Gerber et al. 2012). This means most people are not likely to have their views challenged and will likely only strengthen their views by talking to people they agree with, while remaining less informed than those in diverse networks. As inequality increases and people become more economically segregated, people will come into contact less with those from other classes who are more likely to have diverse preferences, which will lead to less informed voters. Political expertise could change this.

Political expertise in a network can change the level of information in a network and increase participation. Those with political knowledge, as measured by others in their network identifying a person as politically knowledgeable, can increase participation (McClurg 2006). This occurs because people become more informed about candidates' positions, how policies might affect them, how to volunteer for a campaign, etc., and this affect holds even when there is political disagreement within the network. However, because McClurg measures political expertise in a network by asking respondents the political knowledge of people they discussed politics with, there could be selection bias because some people reported not discussing politics, so those who are already interested in politics and are likely to participate are already in networks with other people who are interested in politics. Additionally, those with more education interact with others with more education and therefore form networks with them (Huckfeldt and Sprague 1993). This means people who are less educated and less likely to be informed about politics will be less likely to become informed. This is important not only for a person having informed political beliefs, but also for participation. 
Previously, social networks were formed by in-person interactions, but the internet has the potential to change the dynamics of social networks, and thus to change who is in what network and who receives representation. But is this actually occurring?

There is some evidence that the internet is changing the structure of social networks. For example, young adults who are not as likely to form large social networks in person, such as people with low self-esteem, are more likely to form them online; social media is encouraging people to participate in networks that they might not otherwise have participated in (Ellison et al. 2007; Steinfield et al. 2008) and helping people to form social networks that they might not otherwise have formed (Lin 1999). These networks do persist over time and social capital gains remain (Ellison et al. 2007). This is important given that as La Due Lake and Huckfeldt (1998) argue "social capital is realized through political communication, thereby enhancing the likelihood that individuals will become politically engaged" (569). They find heavy internet users are more likely to volunteer with community groups, and the more they engage in political discussions online the more likely they are to participate in political activities offline. Therefore, there is evidence these online networks seem to be performing in the same way offline networks perform.

Online social networks supplement offline activity by providing people a way to increase their participation, this is due to the fact that people who participate in political discussion are more likely to participate in political activities whether this discussion is online or offline (Wellman et al. 2001). Gainous et al. (2013) find this to be the case, those with relatively high socio-economic status do use online social networking sites and the internet to gather politically relevant information, regarding elections for instance, while those with lower high socioeconomic status do so less frequently, reflecting the real-world divide in political participation. 
The internet and social media does make it easier for campaigns to reach individuals and expand the number of people they are able to reach, as was seen with the 2008 Obama campaign when the campaign was able to reach racial minorities, class-based groups, and various other groups through the use of social media, and in turn use these connections to increase participation (Cogburn and Espinoza-Vasquez 2011). Online networks seem to be bringing more people into the political process, but there could be the issue that people are not actually becoming more informed, just as with real life networks people in a virtual network may tend to interact only with those who have similar political views.

Prior (2005) finds greater access to cable television and the internet does increase political knowledge for some, but decreases political knowledge for others because of the greater number of entertainment options. Regardless of the forum of media, people are selective in their media consumption and gravitate towards information that supports their views (Stroud 2008). The internet simply makes it easier for people to seek out only what they agree with. Previous literature is showing the internet is not likely to help people become more informed who do not want to become informed and is likely to lead to more people seeking out only information they agree with. The impact of the internet is also limited in terms of usage, only about half the population of the world uses the internet to some extent and use varies widely from country to country (Broadband Commission for Sustainable Development 2016). Developed countries have the vast majority of their citizens online, but in some countries, largely those in Sub-Saharan Africa, internet use in the single digits (Broadband Commission for Sustainable Development 2016).

When a person talks to someone who engages in political activities they are more likely to engage in political activities such as having a bumper sticker, putting up a yard sign, etc. 
(Kenny 1992). Thus, when someone is in a network where people are not likely to participate they will be less likely to participate. However, other factors within a network can affect participation. A group having a common identity, as well as attachments to family or clan, increases participation (Hillman et al. 2015, Lim 2008). Groups that believe they may benefit are also more likely to turnout to participate, while groups that do not think they will receive benefits will be less likely (Hillman et al. 2015). Members of lower class networks are more likely to be uninformed, yet moving up in class, where there are more educated people, those in these networks are more likely to be better informed and to participate, though not reaching the level of elite networks where they are connected to policymakers. Of course, a person's social network is not the only factor that determines what class a person falls into, how likely they are to participate, and how much influence over policy they are able to have.

\section{Income, Skill, Political Participation, and Inequality in Representation}

The network a person belongs to effects how much influence they are likely to have and their political participation, but income and skill level also effect political participation and influence, and, as discussed above, the network a person belongs to. Income and skill level are strongly related to how much an individual participates in the political process (Brady et al. 1995). There is strong evidence that the lower a person's income and skill level, the less likely they are to vote because they are less engaged in the political process (Lijphart 19976; Lijphart 1999; Mahler 2008; Gallego 2010; Leighley and Nagle 1992). Not only are those with higher incomes more likely to vote but they are more likely to engage in other political activities, such as giving to campaigns, because they possess the resources to do so (Ansolabehere, Figueiredo, and Snyder 2003). Many wealthy elites see giving to philanthropic causes as an obligation of

\footnotetext{
${ }^{6}$ Income and education increase a person's likelihood of voting (Lijphart 1997). What is important to this theory is individuals with higher incomes are more likely to vote, not why higher income individuals are more likely to vote.
} 
their position in society, feeling pressure from those around them to give (Ostrower 1995), to that extent elites believe giving to a political cause benefits society they are also likely to see political contributions as an obligation.

As income increases, the number of political acts a person engages in, such as voting, contacting a candidate, serving on the board of a political organization, and protesting, increases (Verba et al. 1995). In addition, greater educational inequality leads to greater economic inequality as income increases with education (Gregorio and Lee 2002; Martins and Pereira 2004). Those with higher incomes are more likely to join an interest group (Boehmke and Bowen 2010; Rosenstone and Hansen 1993), more likely to work for a campaign and donate money to a campaign (Ansolabehere et al. 2003; Verba et al. 1995), and more likely to donate to an interest group (Verba et al. 1995). Money not only allows an individual to donate to an organization but also gives them the ability to participate in other ways, from being able to afford to travel to a political event, to being able to afford childcare and/or time off of work in order to work with a political organization. Those lower down the income scale lack these resources, and while they can still participate in politics, it will be more difficult for them to do so. This is not to say those lower down the income scale cannot have influence through activities such as voting or volunteering for a campaign, but rather those higher up are more easily able to engage in a wider range of activities to influence policy.

As Schattschneider (1960) argues, those with more wealth find it easier to participate in interest groups; therefore, these interest groups will be biased toward representing the wealthy. Since income increases participation in mass-based interest groups, these groups tend to represent the interests of higher income individuals. Mass-based interest groups include groups concerned with social issues and labor unions. However, professional associations that represent 
relatively wealthy professionals have risen in prominence as inequality has increased (Bartels 2008). More wealth increases a person's ability to influence political outcomes in multiple ways, from donating money to candidates to interest group participation. Labor unions are able to help their members overcome the barriers of collective action by providing enough direct benefits to their members that their members have an incentive to stay in the union and contribute to the unions' efforts to influence policy, of course people will only remain a part of a union if these benefits continue (Olson 1965). There is the caveat that labor unions are funded by their members who are low-middle income, while groups concerned with social issues elicit funds from all people, their donors tend to have higher incomes because they can afford to give. For example, women's groups tend to represent white upper middle class and white upper class women's interests because this is who participates and donates to these groups (Strolovitch 2007). Even when the relatively poor are able to organize they are not necessarily successful. Social movements, in addition to social networks, are also important to achieving representation. Klandermans and Oegema (1987) explain that there are four steps to joining a social movement, "becoming a part of the mobilization potential, becoming a target of mobilization attempts, becoming motivated to participate, and overcoming barriers to participate," adding "the more motivated people are the higher the barriers they can overcome" (519). In order for a person to participate in a social movement, or to engage in a political act, such as voting, a person must have the motivation to do so, after this they must have the ability to overcome the barriers to participation. The mobilization potential of a movement is those who have the potential to be persuaded to act in a movement (Klandermans and Oegema 1987). Not all people who will benefit from a movement will participate in the movement because the cost 
of action will outweigh the benefits for many, but when there is reason to expect a payoff people will participate (Olson 1965).

There is the caveat that even when mobilization is achieved, in order to be successful at achieving the goals of a movement those in the lower class need support from other groups, and a favorable political climate with people who share their goals. When looking at farm worker unionization efforts in the US, Jenkins and Perrow (1977) found workers were only successful once they got the support of other groups and there was a change in government sentiment away from agribusiness and in favor of workers' rights; this was led by a broader social movement at the time among more affluent members of the public, not the less affluent workers.

Gender is also an important factor when determining influence because women are not given the same access as men. For example, when women do run for office, because of bias against female candidates, they have to be higher quality candidates than their male counterparts in order to win an election (Fulton 2012). But when female politicians are visible in news coverage adolescent girls are more likely to indicate a willingness to want to be politically active (Campbell and Wolbrecht 2006), however this is limited because of the fewer number of female politicians, thus likely limiting participation of women at all income levels.

Those with more income participating more in political activities incentivizes politicians to focus on representing the interests of those with higher incomes. Politicians pay attention to who participates, and the lower the turnout and participation is among a group, the less politicians will consider their preferences. The preferences of high income individuals influence the policy process, while the opinions of the rest of the population, especially the poor, are largely ignored (Gilens 2005; Gilens 2009; Rigby and Wright 2013). This is complicated by the elite sometimes being able to lead mass opinion when it comes to foreign policy, while 
sometimes the mass public is able to lead opinion (Cunningham and Moore 1997). Since political and private sector elites are in the same social networks it is likely the private sector elites are influencing the preferences of public sector elites. There is token representation of the overall electorate, but with a focus on representing the selectorate, and only a relatively small segment of the selectorate.

Not only do politicians ignore the preferences of those lower down the scale, the public can have stated interests that seem contrary to their own interests, and this can lead to representation that is contrary to their interests. Bueno de Mesquita et al. (2003) argues the winning coalition must be satisfied in order for the ruling coalition to stay in power. Within this winning coalition there will be those who have influence over the agenda and who generate and maintain policies that benefit them, and those who are more likely to follow. For example, a majority of those who supported the Bush tax cuts, tax cuts that disproportionately went to the wealthy, were not wealthy, but many supported them with the hope of one day becoming wealthy (Bartels 2005). It may be the case, as Hacker and Pierson (2005) demonstrate that policy can be engineered in a way to distort the public perception of the policy, with the policy appealing to the base of the party and then being sold to voters as being widely beneficial; this is what they argue was the case for the Bush tax cuts. This notion is somewhat supported by Bartels (2005) who finds more informed individuals were less likely to support the tax cuts. The information voters have matters to what policies voters can be persuaded to support.

That voters lack knowledge is the case when it comes to inequality, and redistribution preferences. When presented with diagrams showing different income distributions the majority of respondents do not know the shape of the income distribution in their country, and actual inequality in a country does not matter to preferences for redistribution policies, but rather 
perceived inequality does (Gimpelson and Treisman 2015). Additionally, in the case of tax policy, most people do not connect policy with inequality (Bartels 2005). However, for politicians and the public, the poor receiving less benefits than the wealthy might not be a problem because the poor are often constructed as lazy and ignorant (Jarosz and Lawson 2002). This lack of information among the public points to many social networks not being informative and could help those with influence to maintain power. Gramsci (1971/1989) argues that the state reproduces the means of production in society. As Carnoy (1984) explains, the lack of a consciousness among those in the lower class causes them to adopt the ideology of those in the upper class. It could be the case that the preferences of the upper class are reproduced in the lower class therefore creating similar preferences, however what happens when preferences are different? When preferences diverge representatives are unresponsive to the preferences of lowincome constituents and instead respond to the opinions of middle and high-income constituents (Bartels 2008). Bartels finds when it comes to issues that are salient to low-income individuals their preferences do not affect US senators' roll call votes, while the views of middle income and high income individuals do have an impact on how senators will vote (Bartels 2008).

Representation not only occurs through the adoption of policies, but also by maintaining the status quo.

Hacker and Pierson (2010) argue, "policy change often occurs when groups with the ability to block change effectively resist the updating of policy over an extended period of time in the face of strong contrary pressure and strong evidence that policy is failing to achieve its initial goals" (168). The few who benefit from the status quo have a strong incentive to keep it in place and thus benefit greatly from their actions, while the many who are slightly harmed have much less of an incentive to act (Olson 1965). There is a strong status quo bias and one where 
representation is tilted towards the wealthy because the wealthy are the ones benefitting the most under the current system, thus the ones with the strongest incentive to keep the current system in place (Gilens 2005). As inequality increases those at the top gain relatively more wealth and therefore more incentive to influence in order to maintain their status, either through action or inaction, while those at the bottom grow in number making the individual benefit each person would receive from any policy decline, and their incentive to act decrease. Over time the policies created by governments can perpetuate inequality by shaping the ability for organized interests, such as labor unions, to act within the market (Hacker and Pierson 2010). This occurs because those with more resources are able to have greater representation, while those with less have less representation (Goodin and Dryzek 1980; Solt 2008), and as inequality increases these discrepancies magnify.

Inequalities in representation are not only maintained by politicians but also by political parties. Politicians are not independent actors and are constrained by their party, so what policies a party adopts matters to representation. Rigby and Wright (2013) argue parties will be strategic in who they provide representation to, appealing to ideologically motived donors who will provide contributions in exchange for policy representation. They find party platforms contain representation of the preferences of middle and upper-income individuals, but not lowincome individuals. ${ }^{7}$ Bartels (2008) finds party, as would be expected, has a large impact on US senators' roll call voting. However, when it comes to representation by income group senators

\footnotetext{
${ }^{7}$ Rigby and Wright (2013) find this is the case for the US, with party platforms in the US being less likely to take into account the interests of the poor in US states with high inequality. They find there is a party difference, when it comes to economic positions, the Democratic party platforms represent those in the top-third of the income distribution, while the Republican party platforms are skewed towards those in middle-income and upper-income groups. When public opinion among income groups diverge on social issues the Democrats again represent the opinions of those in the upper third and Republicans represent the opinions of those in the middle third of the income distribution. The party platforms only include the opinions of those in the lower-third of the income distribution when they coincide with the opinions of those in the top two-thirds.
} 
are most responsive to the views of high-income and middle-income individual's, and not responsive to the preferences of low-income individuals. Inequality in a country represents the income distribution, therefore it is important to determine what influences inequality.

\section{Trade and Income Inequality}

The standard model of trade and wages argues, in human capital abundant countries, when there is trade openness the wages of skilled workers will increase, and the wages of unskilled workers will decrease, while in labor abundant countries the opposite will occur (Stolper and Samuelson 1941; Wood 1997). ${ }^{8}$ Therefore, some states should see an increase in inequality from trade, while others should see a decrease. However, inequality has increased across states (Milanovic 2012). Trade, in conjunction with technology, has helped lead to this increase in inequality. This said, trade is not the only factor that has led to an increase in inequality, factors such as social network, race, education (Wright 1978), and gender (Davies and Joshi 2002) all affect inequality.

Much of the increase in inequality can be attributed to technological change, with technology improving the productivity of skilled workers while simultaneously providing direct competition to unskilled workers (Acemoglu 2002; Acemoglu 2003; Jaumotte et al. 2013;

Berman et al. 1998; Kurokawa 2011). Trade accelerates the spread of technology, which in turn, increases inequality (Berman et al. 1998). Thus, the gains from trade go disproportionately to skilled workers, who see their incomes relative to other workers increase. This gives skilled

\footnotetext{
${ }^{8}$ Human capital is the skill level of an individual. This theory is part of the Stolper-Samuelson Theorem. The Stolper-Samuelson Theorem says countries will have a comparative advantage in the production of goods that use their relatively abundant factor and will have a comparative disadvantage in the production of goods that are produced using their relatively scarce factor. For human capital abundant states their relatively abundant factor is skilled-workers, while their relatively scarce factor is unskilled workers; for human capital scarce states their relatively abundant factor is unskilled workers while their relatively scarce factor is skilled workers. When there is trade openness with a country that has the opposite endowments, the relatively scarce factor will effectively increase in abundance, and therefore wages for these workers will decrease, while the relatively abundant factor will decrease in abundance and wages for these workers will increase.
} 
workers a strong incentive to be in favor of free trade. While unskilled workers will face increased competition from free trade, both from other workers and technology, giving them an incentive to be against trade. These two groups have conflicting interests, but skilled workers, who see their incomes increasing relative to unskilled workers, are winning out. This suggests that skilled workers, with their increased incomes, are having more influence than unskilled workers with relatively low incomes. The evidence on who participates in the political process, and who is more likely to have contact with policy makers, suggests this is likely the case as the world pushes toward greater openness.

\section{Trade Policy: Individual Preferences Disconnected from Policy Outcomes}

The state of the economy is frequently what is most important to voters, and voters will punish politicians electorally when the economy is doing poorly, when it comes to trade policy politicians will respond to voters, but they will also respond to interest groups (Mansfield and Milner 2012). Mansfield and Milner go on to argue voters will have more of an indirect influence on trade policy because they determine the ideology of the pool of candidates that they select from and therefore the policies they will support. This can help explain the push toward free trade.

The world pushed towards more open trade in the second half of last century (Milner 1999), and although there have been some setbacks, liberalization has continued, with declining trade barriers and greater openness (Milner and Kubota 2005). But who is leading this liberalization? That is, who is likely having influence on policy? Ezrow and Hellwig (2014) make the case that political parties do respond to the mean preferences of voters when it comes to trade policy, however they also argue economic interdependence with other nations can drive parties to be responsive to markets. The focus here is on what groups political parties, and the 
politicians that belong to them, respond to. As discussed above it seems the ones who receive representation are elites and to some extent those in the middle class, and as will be discussed below, interest groups also receive representation.

The current literature on inequality and trade policy does not fully take this differing influence of constituents into account, particularly how the influence of elite networks, the lower class and the middle class, and interest groups, changes with inequality. While previous authors have looked at the impact of interest groups on trade policy (Ehrlich 2007, 2011; Fordham and McKeown 2003; Grossman and Helpman 2002), the interaction between constituent preferences, interest group influence, and trade policy (Bailey and Brady 1998), how inequality effects trade openness (Dutt and Mitra 2002; Dutt and Mitra 2006), the impact of trade on inequality (Puga 1999; Robertson 2000; Wood 1997), and the varying influence of those in the public given this inequality (Bartels 2008; Gilens 2005; Gilens and Page 2014; Hacker and Pierson 2010; Winters and Page 2009), there has not been a comprehensive explanation of how these factors interact to influence trade policy. Bailey and Brady (1998) do find US states with constituents who are economically homogeneous in terms of employment and union participation have senators who are more likely to abide by constituent preferences when it comes to trade policy votes, while states where constituents are more economically heterogeneous have senators that are more likely to defer to the preferences of interest groups. This does provide some evidence of interest groups being able to assert themselves into trade policy when there is disagreement among constituents, which could be the case as inequality increases and trade preferences diverge because of the increasing differences in relative incomes. Alternatively, the public's preferences may become more homogeneous as the size of those with relatively low incomes increases. However, this leaves out the relative ability of each group to influence. 
At the country level, there is evidence that because labor abundant states have relatively cheap labor that is competitive on the global market, inequality triggers openness in labor abundant countries, as the poor push for more openness (Dutt and Mitra 2006). In capital abundant states, labor is relatively over paid and less competitive on the global market, therefore an increase in inequality triggers more protectionism, as workers in these states are concerned about competition (Dutt and Mitra 2002; Dutt and Mitra 2006). When factors such as regime ideology and whether or not a regime is pro-worker or pro-trade, are considered, the opposite relationship can occur (Djerdjian 2010). Pro-worker regimes will protect workers in capital scarce states, while a pro-trade regime in a capital abundant state will lead to more free trade. The problem with the state level theories is they rely on the assumption that public opinion in democracies influences trade policy outcomes, without providing evidence this is the case. If it is assumed individual preferences influence policy outcomes in democracies, then the state level findings should be consistent with themselves and the individual level findings, but they are not.

At the individual level, some evidence suggests that the higher an individual's skill level in a human capital abundant state, the more likely they are to be in favor of trade openness because they are more competitive on the global labor market (Mayda and Rodrik 2005; O'Rourke et al. 2001). Therefore, unskilled individuals in these states will prefer protectionism because they are relatively scarce in capital abundant states, and thus are less competitive globally (Mayda and Rodrik 2005; O'Rourke et al. 2001). However, there is contradictory evidence pointing to high human capital workers preferring greater openness and low human capital workers preferring greater protectionism, regardless of the endowments of the state. With these authors arguing high human capital workers are able to be more competitive globally and are better able to take advantage of the benefits from trade, while unskilled workers are less able 
to (Beaulieu, Benarroch, and Gaisford 2011; Beaulieu, Yatawara, and Wang 2005; and Hainmueller and Hiscox 2006). Inconsistent with these findings, Baker (2003) argues, as an individual's income moves from the highest level to middle-income, support for trade increases because middle-income workers benefit the most from the cheap consumer goods trade brings. Then, when going from middle-income to low-income, support for trade decreases because trade means increased competition for the goods these workers produce. ${ }^{9}$

While some individual level findings are consistent with the state level, they are not consistent with the evidence on who benefits the most from trade. Regime type may be a factor, but this still ignores that those with different incomes, education, and networks participate and therefore influence at different rates. Furthermore, there is evidence most voters simply do not consider trade policy when deciding who to vote for (Guisinger 2009), although at times trade policy can become a salient issue to the public (Hicks et al. 2014). Hicks et al. find when Costa Rica held a referendum on CAFTA-DR voters became highly engaged in the process, largely because of efforts by political parties to frame the agreement, leading to turnout in the referendum of 59.2 percent, showing trade policy can become a salient issue. However, when trade policy is not a salient issue a small segment of the population could be left to influence trade policy, as well as providing a better opportunity for interest groups to assert themselves. Yet, whether or not trade policy is salient, as will be discussed in the theory chapter, it is likely elites and interest groups will assert the greatest amount of influence. But a discussion of what interest groups are, how they influence policy, and previous literature on the influence interest groups have on trade policy is first needed.

\footnotetext{
${ }^{9}$ This is assuming income and skill level have a positive relationship, there is strong evidence in favor of this being the case (Gregorio and Lee 2002; Martins and Pereira 2004).
} 


\section{Variation in Interest Groups}

Thomas (2004) defines interest groups as "an association of individuals or organizations or a public or private institution that, on the basis of one or more shared concerns, attempts to influence public policy in its favor" (4). Interest groups are organized private interests that attempt to influence public policy.

There are two broad types of interest groups: business interest groups and mass-based interest groups. Business interest groups are funded by firms and represent their interests. Massbased interest groups are funded by the public and represent their interests. These groups can overlap when the preferences of members of the public and businesses overlap. For example, members of the public and gun manufacturers fund the National Rifle Association. Individuals donating to the NRA and gun manufacturers have similar interests and work together to promote these interests.

Mass-based interest groups include groups that are concerned primarily with social policy, such as LGBTQA groups and abortion rights groups, and groups with primarily economic concerns, such as unions and professional associations. Business interest groups are concerned only with economic issues, and they will only be concerned with social issues to the extent that they affect economic issues. The primary goal of business is profit maximization. Even activities such as promoting environmental issues or social justice issues serve the purpose of promoting a certain image of a business. ${ }^{10}$ Therefore, business interest groups are concerned with policies that affect profits and other economic concerns.

Because businesses have specific interests, business interest groups will be focused, while the general public has diffuse interests (Olson 1965). Members of the public have

\footnotetext{
${ }^{10}$ While there are certainly exceptions to businesses being run strictly for profit, and ideology restricting profit, for example Chick-fil-A not opening on Sunday because of its founder's ideological convictions, these are not the norm.
} 
numerous concerns, and broad concerns such as the environment, while the concerns of businesses are much narrower, such as profit maximization through mining coal. However, when someone donates to or joins an interest group, it is because the interest group promotes a certain agenda. This means mass-based interest groups will generally be highly focused, but the interests they represent as a whole will be much more diverse than the interests represented by business interest groups.

As discussed above, income is positively related to interest group participation and political activity, therefore mass-based interest groups will be biased toward representing those with higher incomes. This means mass-based interest groups do not represent all people's interests, but rather they tend to represent small segments of the public and their interests, and are geared towards those with relatively high incomes (Gilens 2014; Schattschneider 1960) because those with higher incomes are more able to participate and participate at higher rates (Verba, Schlozman, Brady 1995). However, poorer and more marginalized individuals are still active in some groups, such as in church groups (Verba, et al. 1993). While interest groups do not represent all segments of the public evenly, they do provide some representation across the public. The exception here is that labor unions, which tend to represent middle-income individuals, will see their strength tied to the size of the workforce in the industries they represent and the willingness and ability of this workforce to unionize, thus tying union size to the size of the middle class.

Interest group systems can be formal, such as in the US where interest groups operate within set guidelines, both informal and formal, operating outside and within legal guidelines, such as in many Latin American countries, or informal, where interest groups operate completely outside of set guidelines. Informal systems exist in places where interest groups are largely 
outlawed, namely autocracies. Both formal and informal interest groups have as their main purpose influencing public policy. Therefore, the activities formal and informal interest groups engage in, with some exceptions, will be similar. They will both try to persuade politicians and the public to adopt their preferences on an issue, with the ultimate goal of passing policy that benefits their members and donors. Informal interest groups engage in activities similar to the activities formal interest groups engage in. For example, giving money to a politician to help them with their reelection campaign. However, in general, the chief strategy of informal interest groups is informal contact with policymakers (Thomas and Hrebenar 2008). The line between interest group activities and corruption is often only a legal one. In mature democracies the interest group system will be formalized, while in transitional democracies groups will have some formal aspects but will be largely informal (Thomas and Hrebenar 2008). Chiefly, what the formalization of interest group activity does in a country is bring greater transparency to the process.

On the one hand, interest groups can engage in corruption; while corruption and lobbying are different practices, they both have as their purpose to influence the decisions of policy makers. Shukla (2015) writes, the essence of lobbying is, "the attempt to influence and not necessarily in the realization of the final outcome, in terms of success or failure" (Shukla 2015, 14). That is, lobbying is an effort by an interest group, either formal or informal, or an individual, to influence policymakers' decisions. Lobbying is a process that entails legal and transparent activities to influence the decisions of policymakers. Transparency means observers can determine how much money is given to a politician by an interest group, who politicians are meeting with, etc. Transparency makes it easier for groups with opposing views to respond to other groups. 
On the other hand, corruption is influence through illegal, and often hidden, channels. A politician engaging in corruption misuses their "public authority for private gains" (Shukla 2015, 14). Corruption can entail giving money directly to a candidate for their personal use, but it can also be giving them money to help with their reelection campaign. What makes the latter corruption, and not lobbying, is a matter of legality. Thus, as opposed to lobbying, corruption is an illegal process, and because of its illegal nature is not transparent.

Corruption occurs at two levels, at the policy implementation level and during the policy making process. At the policy implementation level bureaucratic officials are the public officials who engage in corruption. Corruption at the policy implementation level alters how laws are enforced but does not change what policies are (Campos and Giovannoni 2007). Corruption at the level of policymakers is an attempt to influence policy outcomes, to change what laws are. Corruption and lobbying occur for similar reasons. This is demonstrated by corruption and lobbying acting as substitutes, with the amount of corruption and lobbying firms engage in having an inverse relationship (Campos and Giovannoni 2007). If corruption and lobbying were not substitutes, the amount of lobbying engagement would not have an inverse relationship to the amount of corruption engagement. Therefore, corruption and lobbying will be conceived of as similar concepts, performing similar functions, and importantly both can be carried out by organized groups.

As a country democratizes, it moves from an informal to a formalized interest group system (Thomas and Hrebenar 2008). This transition occurs because formal interest groups and the legal processes they use to influence policy makers develop over time, just as democratic norms take time to form and become accepted. When a country is transitioning to democracy, those who benefitted under the old system will be resistant to change. Furthermore, it will take 
political will to take on the complex issues of interest groups giving to campaigns, with entrenched interests resisting reforms that could mean greater competition.

There is significant variation in how interest groups operate in different countries and regions. But there are also commonalities. Identifying commonalities in interest group systems is important to developing a theory that applies across various types of states. In mature democracies, such as the US and Western European countries, interest groups are formalized. A formal interest group system means there are set rules for the activities interest groups can and cannot engage in, and the pathways through which these groups engage with politicians and the government are transparent and formalized. For example, the European Union keeps track of interest groups that access the European Parliament and this information is available to the public. Another example, is that in the US all politicians must disclose campaign contributions from interest groups, and this information is available to the public. Transitional democracies, such as most African and Latin American countries, tend to have informal interest groups, while moving towards a formal interest group system. A transitional democracy is a country moving from an autocracy, where interest groups are, in general, severely limited or outlawed, to a democracy, where interest groups are allowed and there are laws governing them.

Interest groups in the United States are ubiquitous. In Federalist \#10 Madison wrote, factions are, "a number of citizens, whether amounting to a majority or a minority of the whole, who are united and actuated by some common impulse of passion, or of interest, averse to the rights of other citizens, or to the permanent and aggregate interests of the community." Madison recognized, because people have diverse interests, interest groups naturally form. Since the 1960s, when research on interest groups in the United States began in earnest, the number and scope of interest groups in the United States has expanded (Noenes, et al. 2004). At the national 
level there is a large amount of spending by interest groups. In the 2012 election cycle the top fifty interest groups gave $\$ 536$ million in contributions. ${ }^{11}$

When talking about economic policies in the US that impact inequality, Hacker and Pierson (2010) characterize policy making as "organized combat," where the role of interest groups shaping distributional policy is emphasized, and where gains in the US are highly concentrated at the top, particularly among those in the top one percent. This has led to a situation in the United States where interest groups are largely able to define the policy positions of the two parties. When representing special interests, a candidate makes the argument that they are representing the general welfare, and in turn, the public supports a party because of the values they represent, rather than the actual policies of the party (Bawn et at. 2012).

Compared to the United States, interest group activity in Western European countries and other developed democracies is not as great but is still substantial (Thomas 2004). The amount of interest group activity in these countries has expanded in recent years, from more of a behindthe-scenes influence, to engaging in activities such as using lobbyists and conducting public relations campaigns (Norton 1999). In some countries, such as Germany, Austria, and the Nordic countries, there are corporatist and neo-corporatist systems, where interests are a part of government (Camerra-Rowe 2004; Nelsen 2004). This special arrangement gives these groups direct influence of the policy making process.

Lobbying has also flourished in the European Union, with most of the lobbying done by business interest groups (Greenwood 2004). Business interest groups have also been the most active and best organized in other countries, such as in Canada (Jacek 2004), Australia, New

\footnotetext{
${ }^{11}$ Center for Responsive Politics. Includes contributions to candidates for federal office, political parties, political action committees (including super PACs), federal 527 organizations, and Carey committees. Does not include contributions to 501(c) organizations because they are not required to disclose their donors.
} 
Zealand (Warhurst 2004), and Japan (Hrebenar 2004). ${ }^{12}$ Thus, the methods of access for interest groups across developed democracies varies, but interest groups, particularly business ones, have gained influence.

Interest group activity in transitional democracies, is, for a lack of a better word, much more interesting. Most interest group activity in autocracies is banned. Those wishing to influence the government must do so through informal channels, and likely need a personal connection to policy makers to have access. The interest group features of autocracies are often retained as a country transitions to democracy. While generalizing interest groups in transitional democracies can gloss over some important differences, there are some common features. Thomas and Hrebenar (2008) argue these common features are: interest groups generally lack autonomy from the government, interest groups are often viewed as illegitimate by the government and the population, the strategies used by interest groups are informal, interest groups often use corruption, interest groups represent a narrower range of interests, mass-based interest groups are often ineffectual because they lack skills and access, and informal interest groups are the norm.

In the transitional democracies of Central and Eastern Europe civil society was relatively weak in the early 1990 s, the time when these countries were transitioning to democracy (McGrath 2008). Since then, business interest groups have gained strength, but corruption and informality remain (Duvanova 2007). There have been attempts to remedy these issues, but the culture of corruption remains (McGrath 2008). For example, Grødeland (2006) describes the hiring of "fixers" by those wanting to influence public officials. These individuals know public officials and, for a price, are willing to influence them. Thus, only those with resources are able

\footnotetext{
${ }^{12}$ Hrebenar (2004) argues interest groups in Japan are as developed as the ones in the United States, and while business interest groups in Japan still dominate labor groups have started gaining more influence.
} 
to gain access to policy makers, which is no different than how interest groups operate in developed democracies. In 1980s Latin American business activity began to expand, and firms became more concentrated. As firms grew larger so did their political influence (Hogenboom and Jilberto 2012). ${ }^{13}$ There was also a rise of left wing mass-based groups in response to the neoliberal policies that allowed for business expansion. As with former communist states, while there are formal interest groups in Latin America, informal interest groups remain the norm. This has slowed the development of formal groups (Thomas 2009).

Studies on interest groups in Latin America, Central Europe, and Eastern Europe are limited, but the studies on interest groups in Africa and Asia are even scarcer. However, they point to similar trends. In India there is widespread corruption and informality (Shukla 2015). In Sub-Saharan Africa, interest groups take many different forms. These include formal interest groups with substantial resources and who push for neo-liberal reforms, to labor unions and churches that push against these reforms, to informal community organizations (Habib and Kotzé 2003). However, even with this variety of interest groups and with some formal channels, informality remains. But this does not necessarily mean smaller groups are shutout, as long as a group can access informal channels they can gain access (Lehman 2008).

Within transitional democracies and developed democracies interest groups play a similar role: they seek to influence politicians and/or the public, with the ultimate goal of achieving policy that is beneficial to them. There is significant variation in how interest groups operate across countries even though they are prevalent across countries, but how do these groups operate to influence trade policy?

\footnotetext{
${ }^{13}$ With the exception of Costa Rica, Latin America consists of transitional democracies.
} 


\section{Interest Group Influence on Trade Policy}

There is evidence showing interest groups, in exchange for the support of politicians, can move trade policy closer to their preferences (Ehrlich 2007, 2011, 2018; Grossman and Helpman 2002). Not only can interest groups obtain trade policy that is more favorable to them, they can get governments to actively defend their interests. At the international level, when there are trade disputes, interest groups can push states toward pursuing an outcome that is favorable to them (Fattore 2012). Interest groups will not only try and influence policy by lobbying already elected officials but will also try to get candidates elected that have ideological positions that will likely benefit them and support parties that produce candidates who are likely beneficial to them, thus groups use multiple ways to try and influence trade policy (Fordham and McKeown 2003). When interest groups are the dominant political force they are able to get candidates nominated who adopt their positions, by providing support to these candidates, lowering how responsive political parties are to voters (Bawn, et al. 2012). As mentioned above, when it comes to trade policy, Bailey and Brady (1998) find the more heterogeneous the preferences of voters on trade the more likely representatives are to be responsive to the electorate, but when preferences are more homogeneous the more likely they are to be responsive to interest groups. Diverse preferences are creating responsiveness giving interest groups an incentive to have homogeneous public preferences.

Social networks also play a role in interest group participation with those who are actively recruited and those who believe they have the opportunity to influence policy being more likely to join groups, and these people are socialized into participation as the norm (Passy and Giugni 2001). This means there will be an upper class bias to who joins interest groups because this is who is the most likely to influence policy. This also means the upper class are 
those who are most likely to be recruited because they are likely to interact with other people who are already part of a group. As discussed above, those who are more affluent are more politically active, and more likely to join groups, meaning there will be an upper class bias in interest groups, leading to a bias in the interests these groups represent. 


\section{Chapter 3}

\section{A Theory of Inequality and the Unequal Influence of the Public and Interest Groups}

As discussed in the previous chapter, there is a significant amount of literature examining class, unequal representation of the public, why people participate or do not participate in politics, how trade influences inequality, and how the public's trade policy preferences are disconnected from actual trade policy outcomes. What is missing is an explanation of how public and interest group influence of public policy changes with inequality. In this chapter I lay out why the preferences of the public are disconnected from trade policy outcomes, how the public's influence changes with inequality, and how the influence of interest groups varies with inequality. Particular emphasis is placed on how the influence of different classes varies with inequality. Since I am concerned with the representation of the public's interests in policy outcomes, I define class in terms of the capabilities each class has to influence policy. I then make the argument that the influence of each of the class groups on policy changes with inequality and, more importantly, as the influence of the public changes so does the influence of interest groups. Interest groups are able to more successfully insert themselves into the policy process as the influence of the public wanes.

Figure 1: Basic Model of Influence

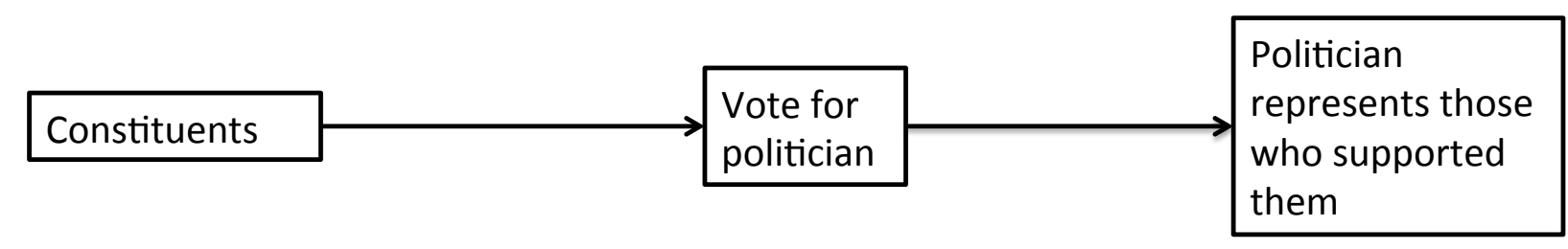

In an ideal representative democracy, when there are two candidates, the voter in the ideological middle is needed for each candidate to win a majority. Both candidates will compete for the median voter. The median voter determines who is elected, and thus the policy choices 
elected representatives should follow (Downs 1957). Figure 1 gives a basic model of representation. In this model, constituents vote for a candidate and, in exchange for this support, the candidate represents the policy preferences of those who selected him or her.

If the median voter model holds, and voters are assumed to act in their self-interest, when there is high inequality the expectation would be significant support for redistributive policies. However, this is not the case; rather, government policies help to increase inequality (Hacker and Pierson 2010). How does this occur? There are three possibilities: first, voters do not always vote in their own interest; second, some voters have greater influence than others; and third, there are other influences on the policy preferences of politicians, all three are the case. As discussed in the literature review, not all constituents are expected to have equal influence over the preferences of politicians. The reasons for this include: voters not having preferences on all issues, politicians influencing the preferences of voters, some members of the public having greater access to politicians, some members of the public being more likely to participate in interest groups or vote than others, and critically, the influence interest groups have on voters and politicians (Bawn et al. 2012; Winters and Page 2009; etc.). What previous research does not examine is the interaction between interest groups, the public, and their relative ability to influence policy as inequality changes.

While exogenous forces will certainly influence policy, especially when it comes to trade policy, endogenous forces will also play a role when a state is forming trade policy (Moravcsik 1997). As Putnam (1988) lays out, parties must compromise on an agreement at the international level, and then the agreement needs domestic approval. In a democracy this means elected officials must approve the agreement. The primary goal for politicians is to get elected to office and, once there, to continue to be reelected (Mayhew 2004). Therefore, politicians will adopt the 
preferences of the interest groups and individuals who increase their chances of election.

Because politicians want the greatest increase in their election chances, those who increase a politician's chances of election the most will receive the greatest representation. This means those who are both willing and able to expend the greatest amount of resources will receive the greatest representation.

The main resource most people have to influence policy is voting; however, money can also be used to influence, and is the main resource of influence for interest groups and elites. Inequality determines the distribution of money among the public. By "inequality" I mean economic inequality, that is, how much money one individual has when compared to another, inequality in wealth. Measures of wealth inequality are limited; therefore, I use measures of income inequality as a proxy for wealth inequality.

When inequality increases, the majority of the population will have fewer monetary resources to expend on influencing policy, while a relative few will have more. While individuals may have the money to expend on influencing policy this does not mean they will do so, they must find an issue salient if they are going to attempt to influence policy outcomes. Under higher inequality the influence of those who have gained relative wealth will increase because they will be able to contribute more to campaigns and interest groups, while the influence of the majority of people, those who have lost relative wealth, will decrease because they will be able to make relatively smaller contributions. If all people in the population give the same percentage in terms of their income as campaign contributions and inequality increases, the well-off will increasingly give relatively more than the poor. Those who have become relatively less well off in the public will still be able to vote so their influence will not disappear, but one avenue of influence, monetary contributions, will become more limited. 
Rising inequality will also affect the influence of interest groups. As inequality increases interest groups that rely on monetary contributions from the public for funding will become increasingly reliant on wealthy individuals, who became relatively more affluent with increased inequality. Interest groups that align with the preferences of the wealthy will gain more resources and therefore influence, while those who do not will lose resources and influence. Additionally, because a large amount of the public will have relatively less to contribute to campaigns, politicians will look to business interest groups for contributions and therefore the influence of these interest groups will increase. When inequality increases, politicians will race to satisfy those who provide them with the most monetary resources, and then will sell the policies of those who provide them with these resources to the public. As Bueno de Mesquita (2003) argues, the winning coalition who selects a leader must be satisfied for that coalition to stay in power, but within this coalition there are those who have greater influence over the agenda of the coalition and the size of this group shrinks as inequality increases.

This theory applies to economic issues, rather than social issues. This is because preferences on social issues are much less based on the economic distribution. This theory does not rely on the legality of influence and thus can be applied across interest group systems (both formal and informal), and in mature and transitional democracies.

\section{The Public ${ }^{14}$}

The public falls into much less distinct categories than interest groups, which were categorized in the literature review. The reason for this is class is not only determined by

\footnotetext{
${ }^{14}$ I borrow from Gilens and Page's (2014) classification of the public and interest groups, using their classification of (mass based) interest groups, business interest groups, economic elites, and average citizens (the mass public). I also break the mass public into additional groups as discussed below. I am adding to Gilens and Page (2014) by examining interest group giving and public opinion by state and how senators vote, while Gilens and Page are examining whether or not public opinion influenced the passage of policy.
} 
income, but also by social and educational factors, as well as occupation. Additionally, categories are not clear-cut because the capability to influence resulting from class are on a continuous scale, this said, breaking the public into categories based on the capacity to influence policy is theoretically and methodologically useful.

Broadly there are two categories: economic elites and the mass public. The mass public can be broken down further into high-middle income, middle-income, and low-income. Wealth is the major determining factor in influence because some amount of money is needed to be able to engage in any political activity. As Khan (2012) writes, "In all societies, other resources can be mobilized to beget money, and money can be used to acquire other resources." The category of economic elites encompasses those who are able to directly access politicians because of their wealth. These are people who are able to get a private meeting with national level politicians, attend an exclusive fund-raising dinner with them, etc. Moving from high-middle income to low-income the potential to influence political outcomes decreases as income decreases because wealth decreases.

\section{Determining Who is in What Category}

There is no set amount of wealth or income that puts someone in one of the categories, rather relative income determines what category a person is in. For example, a family with an income of $\$ 100,000$ in the US where GDP per capita is $\$ 56,115$ would not be considered part of the economic elite, while in Honduras where GDP per capita is $\$ 5,095$ a family earning this amount would be considered part of the economic elite (World Development Indicators 2015). A person's relative income in comparison to global incomes is not important to determining influence. What matters is their income relative to the others people's incomes in their country because this determines their ability to influence domestic policy. 
Inequality is important to influence because two countries could have the same amount of wealth per capita, but different wealth distributions, and therefore differences in who has influence over policy. In a country with no inequality, wealth will not be a determining factor in who has influence; all people will have the same constraints from wealth on their influence, such as being able to afford time to participate in an interest group or being able to afford to give to an interest group. Instead, influence will be based on those who are willing to be politically engaged and those with the knowledge of how to be engaged. Those who are interested in politics will participate and those who are not will not, therefore what policies get passed will be determined by who has a greater number of people on their side.

In a country with high inequality, policy outcomes will be based more on the preferences of the few and wealthy, rather than the preferences of the many. Those with relatively little wealth may be able to afford to donate to an interest group, to volunteer, and to vote, giving them some influence. However, the relatively wealthy will be able to largely drown out the influence of the relatively poor. The relatively wealthy will be more able to engage in activities like donating to an interest group or volunteering, and will be more likely to have direct contact with politicians. This in turn will give them greater influence over the agenda and preferences of politicians, and therefore the policies that get adopted. The relatively poor will still be able to vote but the relatively wealthy will be driving who the relatively poor are voting for because candidates will rely on the wealthy for funds. Therefore, assuming influence from no other factors, inequality will lead to greater influence from the wealthy, and less from the poor.

When there is inequality, as is the case in all countries, wealth becomes another factor that is useful in determining how much influence a person is able to have. Those with greater wealth are better able to participate, and even when everyone in a society has their basic needs 
met and has disposable income to spend, for example on donating to a campaign, or attending a protest, participating in an interest group, etc., those who are relatively wealthy will be able to engage in these activities more and have greater influence. Thus, relative income helps determine who falls into what category of potential influence. Before I go into more detail of what determines who falls into each category, it is necessary to discuss why categorization of the public is necessary.

\section{Capabilities that Determine Class}

As previously discussed, I divide people into four classes based on their ability to influence policy outcomes, going from most influence to least influence these categories are economic elites, high-middle, low-middle, and low. I will refer to the bottom three groups collectively as the mass public. Verba et. al (1995) give time, money and skills/knowledge as the requirements for participation. Time, money, and skills are all needed to influence policy outcomes, and in addition to these factors I add the network a person belongs to. With a persons' social network determining who they are able to directly influence through personal contact, and indirectly through personal relationships. These four factors will determine which category a person falls into.

By time I am referring to the hours engaged in a given activity, either engaged in by the person themselves, or employing others, that is, buying people's time. Time is necessary to participate in any political activity. For example, if someone is going to vote they need time to travel to the polling place and time to vote, and if election day is not a holiday they need to be able to afford to take time off from work. While free time is relatively evenly distributed through the population (Verba et al. 1993), the wealthy have the ability to buy free time. The relatively wealthy can afford to hire a nanny, a maid, etc. and to devote their time more to 
activities that they desire to engage in. ${ }^{15}$ Furthermore, people can be paid for their time to engage in political activities, they can be hired to do everything from canvassing neighborhoods to managing an interest group. Those with more money are able to have more free time and are able to purchase more time from other people.

Knowledge encompasses both the knowledge an individual has, and the knowledge of others that can be purchased. For example, hiring an advertiser to come up with an advertising campaign, or purchasing the time of an expert pollster. Knowledge is required for participation at any level, for example if a person wants to vote, at a minimum they have to know where the polling station is and what day is Election Day. The wealthy are more able to purchase the expertise of other individuals to work on their behalf, they can afford to pay for information that is not readily available. Furthermore, beyond free government-sponsored education, it requires money to become educated, in addition to education being a useful way to build a network, as was discussed in the literature review.

Wealth not only increases political participation among the populace, but can be used to buy access to politicians beyond an individual's or group's other capabilities. Any individual only has one vote and are limited in how active they can be in an interest group or campaign. In comparison, a person's spending is only limited by the amount of money they have. Money is then used by politicians to increase their reelection chances. Politicians will pay attention to the preferences of economic elites because of the amount of money they are willing to spend. This is the case because even though economic elites have relatively few votes, in order for a politician to engage in any campaign activities they need campaign funds. Politicians will also

\footnotetext{
${ }^{15}$ Other factors beyond time, education, and income can increase how politically active constituents are. For example, African American churchgoers are more likely to be involved in politics in some way, regardless of their income (Brady et al. 1993), as are strong partisans to be involved in an interest group (Boehmke and Bowen 2010), but, in general, political participation increases with income.
} 
pay attention to the preferences of those in the public who have less money but more votes because politicians need votes to win election, however economic elites will have an advantage by being able to have direct contact with politicians and being able to offer politicians significant amounts of money.

Economic elites in a sense are getting a first mover advantage by being in the same networks as political elites. They are able to directly pitch policies to politicians, which politicians may in turn sell to the mass public. This is not to say the rest of the public will be left out, but rather in order to have the same advantage of speaking directly to politicians they will have to form an interest group, with the leaders of this group having access to politicians. For example, the leaders of a union and not union members, will have access to politicians, public influence here in turn relies on interest group leaders keeping the preferences of their members at the forefront and not pursuing their personal interests. This same amount of influence in terms of getting a politician's ear requires greater numbers of people pooling their resources, and thus less influence per person. Wealth can have a multiplying effect: first, it helps to influence the preferences of parties and politicians, and second, it discourages people from voting who see themselves as having little influence, while those who believe they will likely have influence will be more likely to participate (Passy and Giugni 2001).

Politicians will need to be strategic to get elected and what strategies they employ (what policies they choose to actively support and campaign on) will depend on the distribution of resources in the populace. Politicians could choose the right strategy by careful research, or by having personal policy preferences that match well with the preferences of the populace, but either way, politicians who are not able to find a way to be a match with the preferences of the 
populace and the issues the public finds salient will not be elected. ${ }^{16}$ When an issue is highly salient low-income voters do participate; Campbell (2002) found this to be the case with lowincome seniors and social security. However, as Campbell points out, participation by lowincome voters is unusual even though it can occur when the issue is highly salient. Therefore, the saliency of an issue may change what issues a politician chooses to focus on. Even when an issue is salient politicians will still need resources to run their campaigns and can choose which issues to focus on in order to try and make them more salient among the electorate, or paying lip service to some issues the public finds salient and then enacting opposing policies once in office.

\section{Income and Preferences}

If people of varying incomes had similar preferences then inequality in policy influence would not be a concern in terms of influencing policy outcomes, however preferences vary by income and therefore who has influence is important. Economic elites will act differently on economic issues from the mass public (Gilens and Page 2014), and have an incentive to act in defense of their wealth (Winters and Page 2009). For example, the ultra-wealthy are concerned with issues like inheritance, having their children continue their legacy, instilling values of wanting to work in their children because their children do not have to work, determining "objectives and goals" for the family and their business(es), and their personal security (Dagher 2016). Those with low incomes in the US are concerned with issues like hunger and homelessness, crime and violence, and healthcare (Jones 2017). Those with middle incomes are concerned with issues like healthcare, the economy, and crime (Jones 2017). While those with

\footnotetext{
${ }^{16}$ Partisan differences do occur in terms of representation. When it comes to roll call votes, Bartels (2008) finds Republican senators are the most responsive to the views of high-income individuals and are also responsive, but less so, to the views of middle-incomes individuals, while Democratic senators are about as equally responsive to the views of high-income and middle-income individuals. Importantly, senators in neither party are responsive to the views of low-income individuals.
} 
high incomes have similar concerns to those with middle incomes, being most concerned with issues like healthcare, the budget deficit, and the economy (Jones 2017). Thus, those with low incomes are concerned more with issues of survival, while the wealthy are more concerned with issues like preserving their legacy and maintaining their wealth.

There will be some outliers whose preferences vary, mainly those who base their preferences more on ideology than self-interest, and while both economic elites and the mass public will find economic issues salient, they will find different aspects salient. Appendix 1 shows how people surveyed by the Latinobarometer in 2015 responded to the question, "what is the most important problem in your country?" Across socioeconomic groups people were concerned with the general economy or economic problems at about the same rate, however as socioeconomic group declines people become more concerned with unemployment. ${ }^{17}$ Thus, in both the US and Latin America, the wealthy tend to be more concerned with long-term economic issues, while those with lower incomes have more immediate economic concerns.

\section{Economic Elites}

Gilens and Page (2014) conceptualize economic elites as "individuals who have substantial economic resources, i.e., high levels of income or wealth—including, but not limited to, ownership of business firms" (566). However, this definition is insufficient because it does not specify how economic elites are distinct political actors separate from the rest of the population, that is, separate from the groups within the mass public. The mass public is made up of those members of the public who must rely on numbers, and interest groups who represent their interests, to influence policy makers. Conceptualized differently economic elites fit the label of oligarchs, while those in the other three categories do not. When Winters (2011) is

\footnotetext{
${ }^{17}$ The Latinobarometer does not ask respondents for income so socioeconomic status is used as a proxy for income.
} 
writing about oligarchs he writes that their power is unique because it is based in material wealth and their power is systemic. Winters and Page (2009) define oligarchs as, "actors who personally command or control massive concentrations of wealth—a material form of power that is distinct from all other power resources, and which can be readily deployed for political purpose" (732).

I define economic elites as a set of the public, who, because of their wealth and income, are able to have direct access to policymakers and are able to have influence at the national level. While there are economic elites at the local and state/provincial level, the concern here is at the national level. The primary feature of economic elites is they are able to gain access to politicians and have politicians notice their policy preferences solely because of their wealth, regardless of the way their wealth is translated to influence. As discussed in the previous chapter economic elites are in the same social networks as policy makers at the national level. This interaction gives them a direct voice to policy makers allowing them to have influence. They are at the top of the income distribution, meaning as inequality increases so does their wealth. A wealthy person must choose to use their resources to influence policy, just as a member of the mass public must choose to use their resources to influence policy. The difference is the wealthy person has more resources. Economic elites may have influence over politicians through other means besides their wealth. Those who do have businesses will use their businesses to promote their business interests, which in turn will be their interest.

Importantly, the capabilities of economic elites extend well beyond elections because of these ties with politicians and because of their wealth. For instance, economic elites can run ads for or against a bill. Mass public voters elect a politician with the expectation of the politician following their wishes and have little recourse during the politician's time in office to actively 
hold them accountable, unless they group together. Economic elites are able to actively run ads, talk with politicians, etc. to try and persuade them. Thus, economic elites are able to continue to have greater influence after an election as well.

Finally, economic elites are not political elites. An economic elite could use their wealth to run for office but, if elected, they would cease being an economic elite because their policy influence would be based on their office, rather than their wealth. For example, Donald Trump used his wealth to gain attention, just as many politicians do, as well as help him become a celebrity, and was able to use this to try and influence the political system from the outside, but when he became president he ceased being an economic elite and became a political elite. Economic elites chiefly influence through their wealth, while political elites influence through their position.

When operationalizing economic elites it is difficult to determine their opinions because income categories are not broken down far enough. However, as Gilens and Page (2014) note, the policy preferences of the top ten percent of income earners in the US are much more highly correlated with the preferences of the top two percent of income earners than the preferences of the average earner. ${ }^{18}$ At a bare minimum, elites have an incentive to preserve the current system they are benefitting under (Field and Higley 1980).

\section{Mass Public: Low-Income, Middle-Income, and High-Middle Income}

The mass public is made up of individuals who are not able to gain access to politicians and influence policy because of their wealth. Within members of the mass public there is significant variation of potential for influence, not just because of wealth but also because of factors like education and willingness to influence. Wealth is a continuous variable, creating

\footnotetext{
${ }^{18}$ Gilens and Page (2014) used the 2011 Cooperative Congressional Election Study, examining preferences across thirteen policy preference questions.
} 
wide variation among individuals in the mass public. Members of the mass public range from those who are relatively poor, and who are likely to have little influence, to those who are just below economic elites. Thus, there are those who are wealthier, more educated, and with more connections who can have more influence, but their individual wealth will not be the prominent factor of their influence as it is with economic elites. Table 1 gives the breakdown of these capabilities by group.

\begin{tabular}{|c|c|}
\hline Category & Characteristics \\
\hline Economic Elites & $\begin{array}{l}\text { Direct access to politicians at the national level, part of elite } \\
\text { network extending across the public and private sector, able to } \\
\text { have a relatively large influence on policy }\end{array}$ \\
\hline High-Middle Income & $\begin{array}{l}\text { No direct access to politicians at the national level, likely to } \\
\text { vote, can participate significantly in interest groups, can donate } \\
\text { to an interest group, less policy influence than economic elites } \\
\text { but more than low-middle }\end{array}$ \\
\hline Low-Middle Income & $\begin{array}{l}\text { Less likely to vote than top two categories, can afford some time } \\
\text { volunteering with an interest group, can donate some to interest } \\
\text { groups, less policy influence than high-middle but more than } \\
\text { low }\end{array}$ \\
\hline Low-Income & $\begin{array}{l}\text { Unlikely to vote, little time to donate, low-knowledge, little } \\
\text { money to donate, discouraged from participating, politicians will } \\
\text { appeal to and try to get them to adopt preferences of those who } \\
\text { are relatively wealthy, have least amount of policy influence }\end{array}$ \\
\hline
\end{tabular}

Those with low incomes have little money to donate to interest groups and campaigns, and can afford to spare little time, those with low-middle incomes have a little more time to donate and some money, and while those with high-middle incomes are able to donate money and time, but do not have enough income to directly influence politicians. As income increases participating in activities like joining an interest group and voting also increases, therefore increasing the potential for influence. There is not as clear of a distinction between the bottom three categories, like there is between economic elites and the other three categories, either a person has access to policymakers or they do not. However, this breakdown is still useful 
because although the tools a person in the high-middle income category uses are the same as the person in the low-income category, the person in the higher category has a greater ability to use these tools.

Because of their limited resources, for any one individual in the bottom three groups to have a large amount of influence is difficult. To have significant influence on policy makers the mass public must act in large numbers, and the numbers needed increase moving down the income scale because relative resources decline. As inequality increases, members of the mass public will have relatively fewer financial resources, but the structure of how inequality changes is not important.

There are a few ways inequality can increase. Those at the top can gain more wealth, those relatively low down on the economic scale can lose wealth, for example those in the highmiddle, low-middle, and low group could lose wealth, or there could be a combination of those at the top gaining and those at the bottom losing. No matter how inequality increases those at the top will have a relatively greater amount of resources to expend while those at the bottom will have relatively fewer resources. When moving from relatively low inequality to relatively high inequality those lower down will have relatively fewer resources to spend and will have to make decisions on how to spend their resources.

If inequality is higher because those at the bottom have less this will mean as their incomes are squeezed they will spend more of their income on basic needs like food, childcare, and health care, meaning less to spend on influencing politics. If inequality is increasing because those at the top are gaining, the relatively less well-off will still have the same to spend on influencing politics, but those at the top will have more to spend and therefore will increase their relative influence, while the relative influence of those at the bottom decreases. Economic elites 
are able to easily meet their needs and can choose where to spend their excess wealth and therefore their influence will not decline, and will instead increase, with increasing inequality.

All members of the four groups do not have the same preferences on an issue, and do not find the same issues salient. However, there will be greater variation in the economic preferences of the mass public than in the economic preferences of economic elites because of the variation in their wealth. Some will be able to easily meet their basic needs and others will not, creating variation in preferences that, while influenced by factors like education and values, will also be influence by wealth. Furthermore, because some members of the mass public will see themselves as having the potential to become wealthy, they will favor economic policies that benefit the wealthy (Bartels 2005). Members of the mass public will still largely base their economic preferences on income. However, it is less important why economic elites and the mass public diverge on issues, and more important that they do diverge on some issues, particularly trade. ${ }^{19}$ With all of these groups wanting to assert influence over policy makers only some are able to have influence.

\section{Policymakers}

Politicians in democracies indirectly exchange the resources they have for votes from the electorate. The chief resource elected politicians have is the ability to make policy. Politicians are able to provide substantive representation on issues, passing policy that is preferred by those whose support them. ${ }^{20}$ Representation does not only come from changing policy, but can also come from maintaining the status quo (Hacker and Pierson 2010; Schattschneider 1960). In order for a politician to provide representation of any group, even a group whose preferences they fundamentally agree with, they need an incentive to do so.

\footnotetext{
${ }^{19}$ As will be discussed in the empirical chapters, preferences on trade varies with income.

${ }^{20}$ Pitkin (1967) defines substantive representation as the representation of a group's interests.
} 
The main incentive is reelection (Mayhew 2004). Politicians' preferences will be determined by who provides them with the best chance of reelection. The groups able to provide the most resources, which produce the most votes, will receive representation. While policymakers do have other interests, such as making what they consider to be good policy or moving up in their party (Arnold 1990), reelection is their primary goal (Mayhew 2004). This is because politicians need reelection to achieve their other goals.

Politicians will be strategic and will adopt the preferences of individuals and groups that give them the most resources. Votes are needed for reelection and money helps them to gain votes. Money is needed for various campaign activities such as, travel, hiring staff, research, and holding campaign rallies. For example, politicians in Mexico are known for handing out gifts to crowds at their rallies, everything from plates to Batman dolls (Kraul 2003), while in North Carolina politicians have been using barbecue at events to try and gain favor with the public since before the country was founded, a tradition that continues today (Garner 2012; Reed 2016). Whether it is barbeque or Batman dolls, or any other campaign related activities, money helps politicians to gain the public's support. A candidate maximizing their resources maximizes their chances of reelection.

Winning election is also a necessary condition for a policymaker to extract rents, profiting from their position without providing any societal return, as opposed to taking money to use for campaign activities. Rent extraction is available to all policymakers but is more likely to occur in countries where policymakers have a lower likelihood of punishment. Therefore, in transitional democracies rent extraction will occur more than in mature democracies. This is because mature democracies have institutions in place to prevent rent extraction, while in transitional democracies these institutions are generally weak or nonexistent. 
Assisting a politician with reelection, or engaging in corruption, entails an interest group or individual providing a politician with some sort of resources. In the case of trade policy those willing to provide benefits to politicians will be those who have the greatest at stake from changes in trade policy. As Olson (1965) argues, the more concentrated the benefits the less chance of free riding; that is, the smaller the group who will benefit, the more likely there is to be lobbying. The endogenous protection model argues, "in response to increased import competition, private domestic interests will intensify their lobbying activity for protection: higher levels of import penetration will lead to greater protection" (Trefler 1993, 139). Under this model firms will lobby for protections and be able to gain protection for their products assuming the negative effects of protection are spread wide enough and that opposition is too costly (Mayer 1984). This can also be extended to say firms will lobby for their interests when they believe this openness will benefit their firm and will achieve their preferences as long as the negative effects of openness are widespread.

Generally, trade has benefits that are concentrated and diffuse, and concentrated harm. Firms will lobby for their chosen trade preferences because of the benefits they provide, and if they have significant strength will be able to dictate their desired policy as well as the rhetoric used. For example, in the US the agricultural industry is able to successfully lobby for subsidies on domestic food production and have been able to dictate the rhetoric that politicians use to sell these subsidies to the public. With politicians on both sides of the isle using rhetoric along the lines of, "farm subsidies help provide food security, help farmers, and create American jobs," instead of rhetoric such as, "farm subsidies increase taxes and are handouts to private businesses.” 


\section{Resources}

The following resources are ones that interest groups and the public can use to obtain representation on policy. Of the following resources, being able to vote for a candidate is the only one the public has that interest groups do not. The public has votes because members of the public make up the electorate. Because politicians are concerned with election, their primary focus is gaining votes. The other resources are ones that indirectly provide politicians with votes. These resources can only assist politicians with their reelection, not elect them.

Voting is a resource with relatively low costs, and when compared to other resources is distributed evenly because each member of the public, assuming they are eligible to vote, only has one vote. Because of the costs associated with voting, such as the ability to make it to the polling place, the time to become informed about the candidates, the time to register to vote, and if election day is not a holiday, the time to take off of work and the money lost from not working, those with lower incomes are less likely to vote (Lijphart 1997, 1999; Mahler 2008; Gallego 2010; Leighley and Nagle 1992). Those who are less likely to vote should expect less representation because they are not providing politicians with a strong incentive to represent them. If a politician is not receiving a constituent's vote because the constituent does not vote, and is unlikely to vote in the future, the politician ignoring their preferences will not cause them to lose their vote.

The electorate are those who cast votes in an election and are distinct from the public in that not all members of the public vote. Members of the public are those who make up the electorate, thus the mass public and economic elites will have votes as a resource. The mass public has significantly more people than economic elites, meaning the mass public will have 
significantly more votes than economic elites. Votes are the main resource of each of the three groups in the mass public.

Money is the main resource of economic elites and interest groups. Money allows economic elites and interest groups the ability to access politicians. Money is also the chief resource politicians need to run their campaigns, as well as being the chief facilitator of corruption. Money is a resource that can be used to purchase the time of individuals, to hire campaign workers, to purchase advertisements, pay for campaign rallies, etc. All of these activities can help a politician increase their vote share. Members of the mass public also have financial resources, but the average amount of financial resources they have is significantly less than the resources of economic elites and interest groups.

As Winters and Page (2009) argue, wealth is not the only source of political power, but it is a major source of power, and can be the most important source. For instance, an individual can volunteer an hour of their time and have some infinitesimally small amount influence, or an individual or interest group can give a contribution that can be used to buy dozens of hours of campaign work. Money is highly important because of its ability to be used to influence other groups (Goodin and Dryzek 1980; Solt 2008). The goal of any office holder or office seeker is to be reelected or elected, and to get reelected you need funds. For example, according to OpenSecrets.org, who aggregates data from the US Federal Election Commission, in the US the total cost of the 2016 presidential and congressional elections were $\$ 6.9$ billion, in 2014 when there were only congressional elections the cost was still $\$ 3.8$ billion. While the US has a long, almost constant election cycle, which increases costs, the high costs of elections is not limited to the US. The total cost of the 2014 presidential campaign in Brazil was $\$ 285.5$ million (Alves 2014). Even in Honduras, which has a relatively low GDP per capita and a small population 
when compared to other Latin American countries, a total of $\$ 40.5$ million was raised by campaigns during their 2005 election (Casas-Zamora and Zovatto 2016). ${ }^{21}$

Money not only provides for reelection, politicians can also be influenced by interest groups and individuals threatening spending against them to engage in activities such as supporting a challenger, supporting an opposing political party, running negative ads, or campaigning on the opposite side of an issue. This threat of resources being deployed against a candidate can provide a strong incentive for a policy maker to adopt a given position. Those with financial resources are also able to orchestrate activities independent of a campaign. These include holding a rally for a candidate, holding a fundraising event, purchasing ads in support or against a candidate, etc. These activities can sway the electorate to vote in a given direction, and only the wealthy and interest groups have the resources to engage in them. Being able to sway the electorate gives an actor the ability to influence which candidates are elected, and in turn, which policies elected officials support. Interest groups can also provide the additional resource of endorsing a particular candidate (Grossman and Helpman $2001 \&$ 2002). However, a candidate will only value an endorsement if a group has a substantial number of individuals in the public that agrees with them.

\section{Resources Changing with Inequality}

Table 2 summarizes how the relative resources of the public, mass-based interest groups, and business interest groups will change as inequality increases. Each of the three groups in the mass public will see their relative resources decline when inequality increases. The number of potential votes the mass public has will stay the same, but they are less likely to vote, because

\footnotetext{
${ }^{21}$ Casas-Zamora and Zovatto (2016) note when discussing this study, because of the unreliability of campaign finance reporting in Latin America, as with most campaign finance data from Latin America, this is an estimate.
} 
those with lower incomes are less likely to vote (Lijphart 1997, etc.). Also, because members of the mass public are below economic elites on the income scale, the mass public's financial resources will decline with increasing inequality. Because mass-based interest groups are reliant on the mass public for funding, their resources will decrease with increasing inequality.

\section{Table 2: Change in Relative Resources as Inequality Increases}

\begin{tabular}{lc}
\hline High-Middle Income & $\Downarrow$ \\
Low-Middle Income & $\Downarrow$ \\
Low-Income & $\Downarrow$ \\
Economic Elites & $\Uparrow$ \\
Mass Based Interest Groups & $\Downarrow$ \\
Business Interest Groups & $\Uparrow$ \\
\hline
\end{tabular}

Mass-based interest groups rely on the public's funding to operate. When inequality is relatively low members of the public are able to donate relatively even amounts. However, when there is relatively high inequality the amount members of the public will be able to donate varies much more. Interest groups need funding and therefore will focus on where they can get the most donations. Under relatively low inequality an interest group will have to cast a wider net because wealth is more spread out, but when wealth is concentrated it will make sense for an interest group to focus on getting donations from a smaller group of people who have relatively greater wealth. The interest group will then in turn try to get politicians as well as the mass public to adopt the preferences of those they received funding from (the relatively wealthy). Therefore, as inequality increases, mass-based interest groups will increasingly become a tool of economic elites to influence policy, rather than a tool of the mass public. Labor unions will see the incomes of the middle-income workers they rely on decline, decreasing their revenue.

Inequality is not assumed to directly affect business interest groups' resources. This is because businesses are not assumed to be directly affected by inequality. When the relative resources of the mass public and mass-based interest groups decline as inequality increase, the 
relative resources of business interest groups will increase in relation to these two groups, but they will decline in relation to economic elites. This means the relative resources of business interest groups overall will increase.

\section{Issue Saliency}

The goal of those in the public, mass-based interest groups, and business interest groups, is to get elected officials to adopt their policy preferences. ${ }^{22}$ They can do this in three ways. Which way they choose depends on the saliency of an issue among the electorate. First, they can appeal to the electorate to get them to adopt their position. The electorate will then vote for candidates with similar positions. Appealing to the electorate can be done indirectly by first funding a candidate, and then relying on the candidate to make the appeal to the electorate, and if the issue is not salient, make it salient to the electorate. Second, they can appeal directly to policy makers, leaving out the electorate. This is where having direct access to policy makers is useful, because the electorate does not find the issue salient, the elected policy maker will adopt the preferences of whoever gives them the most resources. Adopting one position over another will not help or hurt their reelection chances in direct terms of votes, but having more financial resources will help them gain more votes. Finally, there can also be the indirect influence of policymakers by interest groups where policy makers choose a policy position and then interest groups provide support to policymakers who share their position (Grossman and Helpman 2002). In practice, because most issues are of at least some saliency in the electorate, a combination of these strategies will be used. In order for any of these strategies to be employed an actor must find an issue salient.

\footnotetext{
${ }^{22}$ The proportion of policymakers who are needed to support a position in order for it to become law will vary from country to country depending on the policy making process. In some countries only 50 percent plus one may be needed, while in countries like the US, because of the filibuster, it takes a supermajority to get most bills passed.
} 
Saliency is a term that is used often in the literature but rarely defined. Someone that does give a definition is Guisinger (2009) who defines saliency as, "the extent to which a voter's utility for a candidate is affected by a candidate's position on an issue" (Guisinger 2009, 535). In this definition, utility is conceptualized as support for a candidate. Therefore, an issue is salient to a voter or interest group if the issue plays a part in why they support or oppose a candidate. Support entails providing resources to a candidate, while opposition entails withholding resources from a candidate, and/or supporting an opposing candidate. As the saliency of an issue to an individual or interest group rises, the resources they are willing to dedicate to the issue will increase.

Because interest groups have diverse interests, any given issue may only be salient to a few. If an issue is salient to an interest group, or individual, they will want their preferences on the issue represented. Some voters may be discouraged when it comes to representation because they may feel that the government does not represent their policy interests, with low-income voters more likely to feel this than high income voter (Passy and Giugni 2001). An issue may be salient to an individual or group, but in order to gain representation they must have some amount of resources. For individuals in the mass public to influence policy they must have large enough numbers, or be organized enough that they can attract large numbers to their cause.

Because members of the mass public are members of the electorate, they have votes, and in large numbers can have significant financial resources. However, the mass public has diverse interests and therefore varying saliency on issues, this means having enough votes and/or enough financial resources to affect policy change requires a substantial portion of the public finding an issue salient and having a similar position on the issue. This will be determined by the amount of people who are willing to be politically active on an issue. The less unified the mass public 
are on an issue, the more opportunity economic elites and business interest groups will have to try and influence policy outcomes on the issue. Holding issue saliency constant, the influence of economic elites and business interest groups will increase with inequality because their relative resources increase, and the influence of the mass public and mass-based interest groups that rely on the mass public for funding will decrease with inequality because their relative resources decrease. The mass public and mass-based interest groups are therefore limited in which issues they can expend resources on to gain influence, reducing their overall influence.

As discussed in the previous section the relative resources of each group are expected to change with inequality, additionally saliency will determine a group's or an individual's willingness to assert influence. When the saliency of an issue declines among the electorate, the likelihood of a plurality of the mass public achieving their desired policy outcome declines because less of the electorate is willing to act on that issue. This is extended to the chances of a mass-based interest group achieving their preferences. When inequality increases, or the saliency of an issue declines among the electorate, the likelihood of a business interest group, or economic elites influencing policy outcomes increases. This is because the majority of the electorate will be less engaged and therefore those with greater resources will be able to assert their influence with less chance of others pushing against them.

Business interest groups and economic elites can oppose themselves, and one another, but as inequality increases or the saliency of an issue to the electorate declines, it will be this conflict that defines politics. Mass-based interest groups and those in the low, low-middle, and highmiddle groups are left out of the debate. 


\section{Trade Policy Saliency}

The saliency of economic issues will vary from group to group. Given the large literature pointing to the existence of economic voting (Downs 1957; Duch and Stevenson 2007; Hellwig 2001; Lewis-Beck and Paldam 2000; MacKuen, Erikson, and Simson 1992; Whitten and Palmer 1999), economic issues always have some saliency in elections. Trade policy is an economic issue, although debate on trade policy can take on a less economic tone, such as turning to nationalist tendencies or noneconomic arguments such as ones related to defense. For example, during the 2016 presidential campaign Donald Trump campaigned against trade by talking about the negative effects of trade on American workers, rather than talking about trade in broad ideological terms as a tool to build relationships with other countries. Who supports and who does not support trade will largely be determined by who believes they will benefit from or be harmed by trade. For interest groups this will take the form of whether or not their members see themselves as benefitting from trade. For example, if a union sees its members benefitting from a trade deal, or if a business interest group sees its members benefitting from a trade deal, they will support the deal.

Who benefits and who is harmed by a given trade policy will vary from policy to policy, and therefore who supports any given policy will vary. Members of the public and interest groups, both business and mass-based, will all take sides. For example, the United States places tariffs on pickup trucks imported into the US. Therefore, most trucks sold in the US are manufactured in the US. This decreased competition increases truck prices, but also increases the number of jobs for US autoworkers. Domestic auto manufacturers and autoworkers will want to keep these tariffs. Auto manufacturers can sell trucks for more, and there are more jobs for automobile industry workers. The United Automobile Workers, who represents automobile 
industry workers, will also want these tariffs maintained because it will benefit their members. However, someone purchasing a truck in the US, unless they are sympathetic to the US automobile industry and US autoworkers, will want these tariffs lifted. They will want the tariffs lifted because tariffs mean higher truck prices. The same will go for any company in the US who purchases trucks, and for anyone looking to import trucks. A different trade policy, such as one on oil imports, would generate different factions.

As with other economic issues, the saliency of trade policy will change from agreement to agreement. Policies with the potential to have widespread impacts in the economy will be salient to both the public and interest groups. For example, the Trans-Pacific Partnership covers a dozen different countries, and because of its large potential impact the deal became a central issue in the 2016 US presidential election. Both the public and interest groups found the deal salient. While smaller trade deals will likely be less salient among the public because their potential impact on the economy is lower.

\section{State Level Variation}

Several factors at the state level will determine how the above model plays out in practice, particularly the structure of the state, the electoral system, and the level of democratic development of a state.

\section{Institutions}

Who makes policy in a country will determine where influence is asserted. For example, in a presidential system where the executive is the strongest actor, such as in many Latin America countries (Thomas and Klimovich 2014), lobbying will focus on the executive. This is versus a parliamentary system where there are a greater number of veto players, where the focus will be on a greater number of policymakers. In the US where there is a joint policy making 
process, the focus of interest groups will be on Congress as well as the president, with the caveat that accessing Congress is much easier than accessing the President. Ehrlich (2011) argues countries with more access points, such as the US, will give greater opportunity to those with resources to influence policy. He also argues countries, such as Latin American states, with fewer access points will provide less opportunities to influence policy. Therefore, countries with more access points will have trade policy that is more biased towards special interests than countries will fewer access points. This will be an important concern when the cases of the US and Latin America are compared. The expectation is all else equal, interest groups and economic elites will have more influence on trade policy in the US than in Latin America.

The electoral system in a country will also determine where influence is exerted. Whether legislators are elected by geographic district or as part of a party list, will determine how interests are considered. In the first situation, where legislators are elected individually, even if they belong to a party, the electorate and not the party, ultimately controls if the legislator maintains their position. The focus of actors seeking policy influence will be on individual policymakers because they are largely independent actors. When it comes to party lists, the preferences of legislators will be more centralized at the party level. The same basic structure will occur, but with preferences aggregated at the party level and disseminated to politicians in that party. The loyalty by party members to the party's policies allows them to move up in the party, and therefore increase their chances of reelection. The party, like individual politicians, will adopt the preferences of groups that give them the greatest amount of resources. The party will then disseminate its preferences to its members.

Additionally, whether or not the electoral system is winner-take-all or proportional will influence how this theory plays out. In a system that is winner-take-all, the candidate who 
receives the greatest number of votes wins, and the other candidates get nothing. If a majority supports a given position on an issue, and the issue is salient to them, they get their policy preferences. This is the same as in a proportional representation system, where parties get seats based on the proportion of the vote they receive. The difference is, in a winner-take-all system, a candidate must receive the most votes to win. On issues that are not highly salient to a large segment of the public politicians will be able to adopt the preferences of interest groups and economic elites who provide them with support. Taking this position will hurt them with a small segment of the population, but they will be able to use the resources they receive to better promote issues that are salient to the mass public, while at the same time adopting the preferences of a small minority.

In a proportional representation system parties can focus on a narrower set of issues that are only salient to a small segment of the population, and can campaign on these issues to win seats. Like a winner take all system, this allows for parties to represent the positions of smaller interests. Those who want a party to adopt their positions, or if a party position already aligns with their position, will support this party. Thus, while the systems are different, representation in both systems relies on the saliency of an issue, as well as the willingness to provide resources in favor of a position on an issue.

\section{Mature versus Transitional Democracies}

In a mature democracy corruption is at a minimum and interest groups and individuals access politicians through formal and regulated channels. The interest group system is well established, known by interested actors, and there are formal channels open for both interest groups and the public to assert influence. Mature democracies have large civil societies and a culture that is acceptant of the legitimacy of interest groups to operate and to advocate for 
specific interests, and have an interest group system that is transparent. The US has a formal interest group system. Thus, the theory is expected to apply directly to the case of the United States. This contrasts with transitional democracies.

When talking about the transitional democracies of Eastern Europe, McGrath (2008) describes the interest group systems as one where "a culture of informality" is the norm. The informality in the interest group system is a common factor across transitional democracies (Thomas and Hrebenar 2008; Thomas 2004; McGrath 2008; Lehman 2008). These countries have not yet developed the civil society that exists in a mature democracy, nor do they have the political culture where interest groups are viewed as legitimate actors or an interest group system that has the skills to effectively lobby (Thomas and Klimovich 2014). Thus, informal channels remain the main way of influencing politicians. This is the case in Latin America.

Two caveats need to be made for how the theory applies to Latin America. First, those with personal relationships with policy makers will have greater access to policy makers, and therefore greater influence over the policy process. Those with access will largely be those representing business interests. Therefore, business interests are expected to have more influence in Latin America. Second, although there are mass-based interest groups in Latin America that are highly active, because they lack many of the skills and access needed to turn passions into policy, these groups will have less influence over policy outcomes. These two caveats mean the effect of inequality on trade policy in Latin America should still exist, but will exist to less of an extent than it does in the United States and other mature democracies. 


\section{Inequality and Regional Variation: Case Selection}

The criteria for selecting what regions/countries to examine were, first, because the

theory only applies to democracies, all countries must be democracies. ${ }^{23}$ Second, variation on inequality across cases was needed to determine how well the theory applies across various levels of inequality, the expectation being the higher inequality, the less influence of the general public, and the more influence of interest groups and the wealthy. To determine variation on inequality first the Gini coefficient was used. ${ }^{24}$ Globally, Gini has roughly a 0.3 range, with a low of 0.25 in Ukraine to a high of 0.56 in Zambia. The mean Gini coefficient globally is 0.36 , with a standard deviation of $0.08 .^{25}$ Table 3 gives a comparison of inequality in the two regions, giving a summary of the state level inequality in the US, and the country level inequality in Latin America.

Table 3: Inequality Across Region/ Country

\begin{tabular}{lcc} 
& United States & \\
\hline Mean Gini Coefficient & 0.46 & Latin America $^{\mathbf{2 7}}$ \\
Minimum Gini & 0.41 & 0.49 \\
Maximum Gini & 0.50 & 0.42 \\
Standard Deviation & 0.02 & 0.57 \\
\hline
\end{tabular}

\footnotetext{
${ }^{23}$ To select on democracy polity democracy scores were used. Countries with a score of five or above were considered democratic. A few states within Latin America were not democratic for some years of the analysis, how these states were handled will be discussed in the research design section of Chapter V.

${ }^{24}$ The Gini coefficient is a measure of income inequality in an area, based on how concentrated earnings are among the populace, and given as a proportion. Gini ranges from zero to one, a Gini of zero indicates no income inequality in an area, everyone has the same income, while a Gini of one indicates perfect income inequality in an area, one person earns all of the income (or zero to one-hundred if Gini is given as a percent instead of a proportion, called the Gini index).

${ }^{25}$ Based on 2010 Gini index estimates from the World Bank World Development Indicators, data were available for 78 countries.

${ }^{26}$ State level Gini coefficient for United States in 2011 from US Census Bureau. National level inequality for the US is for 2010 and from the World Bank World development indicators.

${ }^{27}$ Gini is for 2011, and from the World Bank World Development Indicators. Inequality is for Latin American States included in the Latinobarometer (Argentina, Bolivia, Brazil, Chile, Colombia, Costa Rica, Dominican Republic, Ecuador, El Salvador, Guatemala, Honduras, Mexico, Nicaragua, Panama, Paraguay, Peru, Uruguay, and Venezuela).
} 
Chart 1: Distance Between Percent of Income Share Held by Bottom $20 \%$ and Income Share Held by Top 10\%, All Countries (2010) ${ }^{28}$

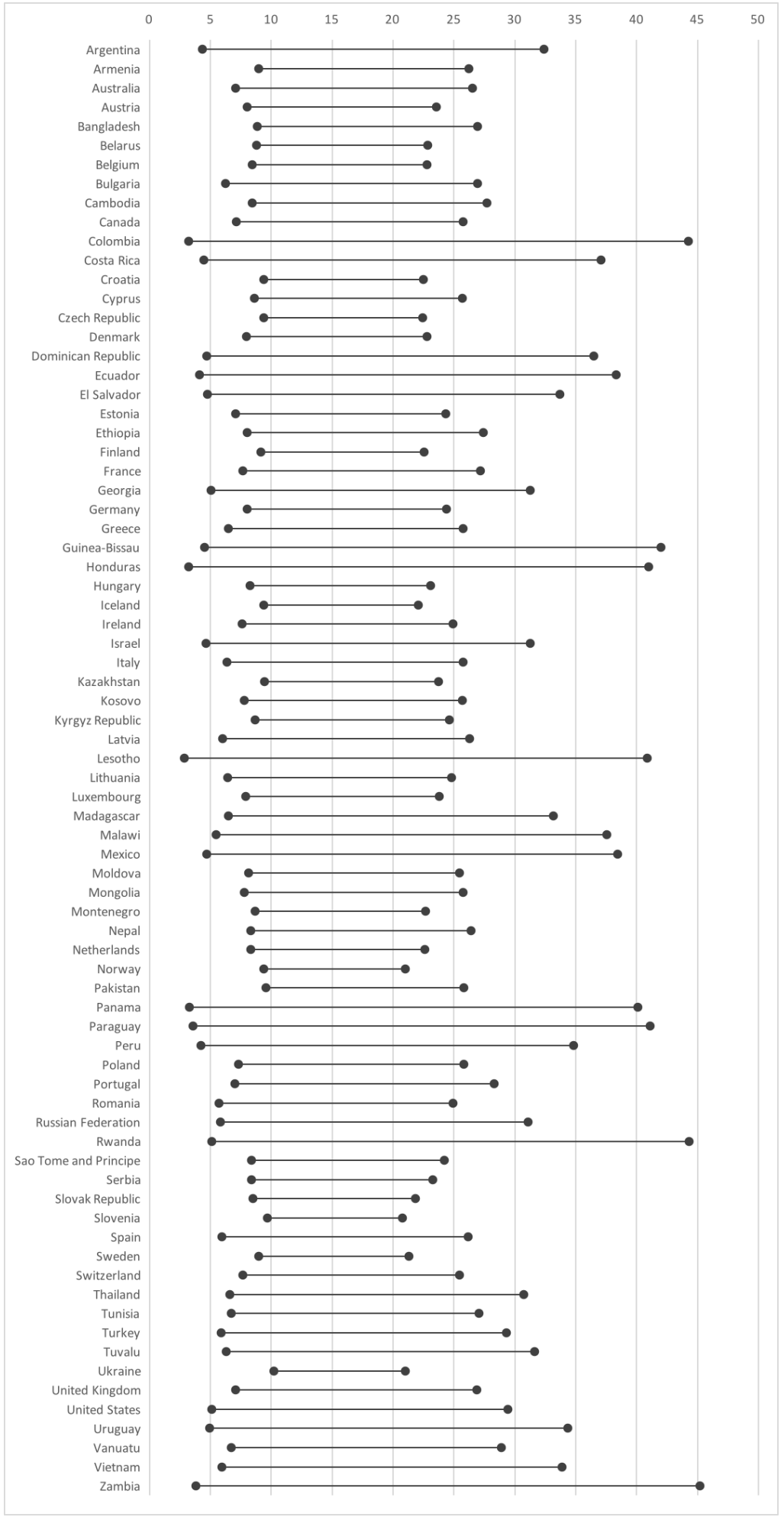

${ }^{28}$ World Development Indicators, The World Bank 
Gini is not the only way of measuring inequality, Chart 1 shows the distance between percent of income share held by bottom 20 percent and income share held by the top 10 percent of all income earners, for all countries for which data are available. The point on the left side of the chart shows the percent of total income earned by the population who makes up the bottom 20 percent of income earners, the one on the right shows the percent of total income earned by the population who makes up the top 10 percent of income earners. Countries with a larger gap between the bottom 20 percent and the top 10 percent have greater equality.

Because the top group is twice as large as the bottom group if both points were in the same place this would show the top group earning twice as much as the bottom group. In all countries, the difference between the highest and lowest income earners is much greater than this, showing income is concentrated among top income earners. In eight states the top 10 percent of income earners receive over $40 \%$ of the income. While income is not concentrated among bottom income earners, the only state where the bottom 20 percent earns more than 10 percent of the income is Ukraine, this is just over 10 percent at 10.21 percent. When selecting cases, variation in equality is needed, and to test if the theory applies across interest group systems developed and transitional democracies are needed.

\section{Latin America}

The Gini coefficient for Latin American states ranges from a low of 0.42 in El Salvador, to a high of 0.57 in Honduras, with the mean of 0.49 , well above the global average. Chart 2 shows the distance between the percent of income share held by the bottom 20 percent in Latin America and the share held by the top 10 percent. When compared to all countries Latin American countries have, on average, a greater share of income held by those in the top 10 
percent, with an average of 28.66 percent of the income held in all countries by the top 10 percent, and an average of 37.99 percent of income held by the top 10 percent.

Chart 2: Distance Between Percent of Income Share Held by Bottom $20 \%$ and Income Share Held by Top 10\%, Latin America (2011) ${ }^{29}$

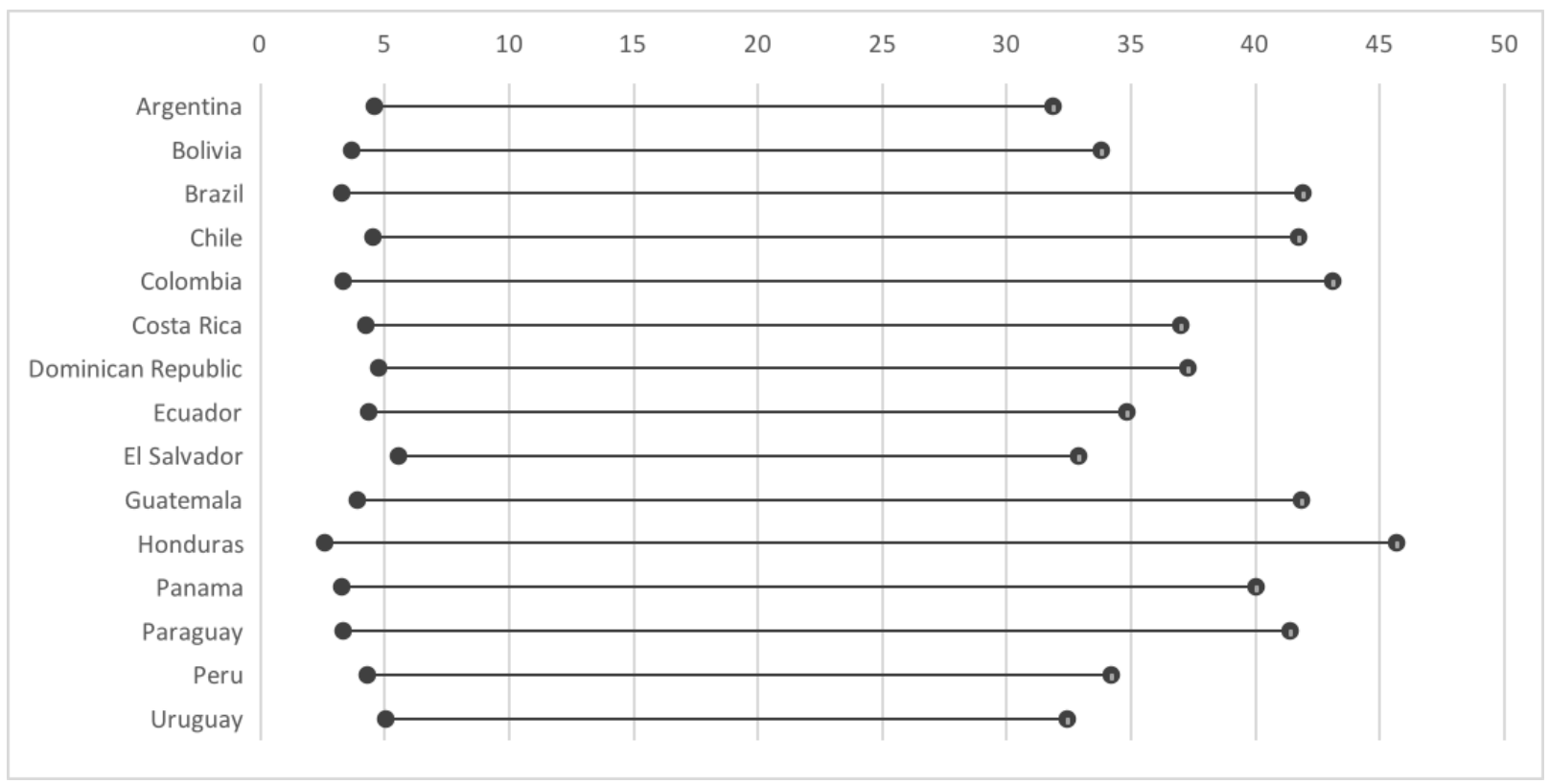

Within Latin America there is substantial variation in the income earned by those in the top 10 percent, ranging from over 45.67 percent of income being earned by the top 10 percent in Honduras to a low of 31.84 percent of income being earned by the top 10 percent in Argentina. Also, in Latin America the bottom 20 percent earn less income than the global average, 6.88 percent globally, compared to 4.06 percent in Latin America. Honduras is again at the extreme, with the bottom 20 percent receiving 2.61 percent of the income. El Salvador has those in the bottom 20 percent earning the greatest share of income, 5.57 percent. Honduras also has the greatest gap between the earnings of those at the bottom and those at the top, a 43.06 percent difference, stated differently those in the top group, with half the population of the bottom group,

\footnotetext{
${ }^{29}$ World Development Indicators, World Bank
} 
earn 17.5 times more income than those in the bottom 20 percent. Argentina has the smallest gap of 27.26 percent. While Latin America tends to have higher income inequality than the world on average, there is variation between the countries, and importantly there is variation between those at the top and the bottom which is essential to testing my theory.

The history of Latin America can help explain why inequality in Latin America is so high, and can also provide insight into how trade policy within Latin American states is influenced by inequality. From the 1930s until the late 1980s, import substitution industrialization (ISI) policies, were implemented in Latin America. ISI policies provided support and protection of domestically produced goods, with the hope of switching from importing goods to producing them domestically. As the rest of the world liberalized and grew, Latin America on the periphery and protectionist, only experienced moderate GDP per capita growth when compared to other regions during this time (Cárdenas, et al. 2000). ISI policies, which had been funded by loans, began catching up with Latin American states in the late 1970s. When Latin American countries did not grow enough to repay their loans they began to default, and their economies went into decline resulting in the lost decade of the 1980s, during that time there was almost no economic growth in Latin America (Cárdenas, et al. 2000). Latin America was outpaced by other states, and after their experience with protectionist ISI policies, they began to liberalize.

Before 1990 Latin American states were only a part of a handful of trade agreements, but from 1990 to 2015 close to fifty bilateral and multilateral trade agreements were joined by Latin American states (WTO RTA database 2016). With neo-liberal reforms spreading across Latin America, Latin American businesses experienced substantial growth (Hogenboom and Jilberto 2012). Economic growth and incomes increased, but GDP per capita growth remained relatively 
low, and inequality increased (World Bank 2016; Wood 1997). The increase in inequality came from Latin American countries not being able to compete with countries with large unskilledlabor forces, such as China or Bangladesh, while at the same time the educated in Latin America were able to take advantage of technology to increase their productivity and income (Wood 1997).

\section{United States}

In the US case I look at the influence of the different actors on how senators vote. The Gini coefficient among US states has a range of 0.09 , with a Gini coefficient for the US as a whole of 0.4. The mean Gini coefficient among US states is 0.46 . The Gini coefficient for Latin American states has a range of 0.15 , and a mean of 0.49 . While these ranges may seem small, the range of the Gini coefficient for all countries is 0.3 .

Chart 3 shows the distance between the percent of income held by those in the bottom 20 percent in the US and the share of income held by those in the top 5 percent, by state. Overall there is a large gap between the earnings of those at the bottom in the US and those at the top. New York has the largest gap between those at the top and those at the bottom, 23.27 percent, with those in the top 5 percent taking home over a quarter of the income, while those in the bottom 20 percent take home approximately ten times less. New Hampshire has the smallest gap, 15.85 percent. However, those at the top still take home almost a fifth of the income, while those at the bottom take home less than four percent. While this does not allow for direct comparison to Latin America and the rest of the world, this chart does show there is significant inequality in the US, just as in Latin America, and importantly there is variation in inequality. 
Chart 3: Distance Between Percent of Income Share Held by Bottom 20\% and Income Share Held by Top 5\%, United States (2015) ${ }^{30}$

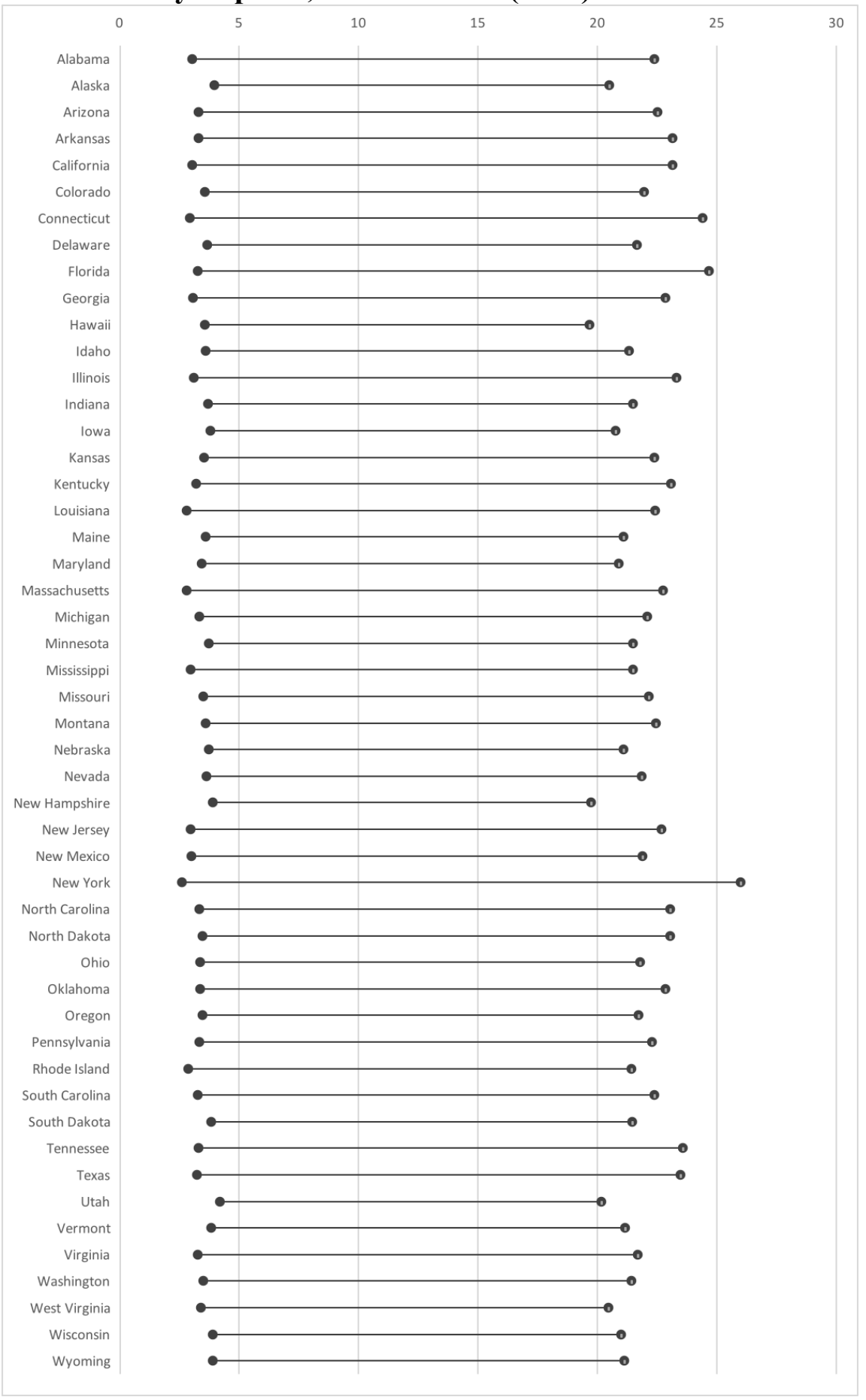

${ }^{30}$ American Community Survey, United States Census Bureau 
The US case allows for the examination of a country in detail at the domestic level. The US has a unique political system. The President negotiates treaties and the Senate ratifies them. The expectation is, because senators are elected at the state level, inequality in a senator's state, not in the country, will determine how much constituents and interest groups influence senator's preferences. Nationally the Gini coefficient is 0.40 , which is less than the average state level inequality, Gini coefficient 0.46 . Although the US has a Gini coefficient that is only a half standard deviation away from the global mean, inequality within US states, is on average higher, than inequality in the country as a whole, but still less than inequality in Latin America, and importantly there is variation at the state level. Also, importantly the US has a well-developed and formalized interest group system.

In the following two chapters I explore how well my theory applies to the US and Latin America. 


\section{Appendix 1}

Most important problem in your country, response by socioeconomic status, proportion in each SES category responding that problem is most important (From Latinobarometer 2015, categories with no respondents not reported)

\begin{tabular}{|c|c|c|c|c|c|}
\hline Problem & Very Good & Good & Average & Bad & Very Bad \\
\hline No answer & 0.00 & 0.01 & 0.01 & 0.01 & 0.02 \\
\hline Don't know & 0.03 & 0.03 & 0.05 & 0.08 & 0.14 \\
\hline Low Salaries & 0.01 & 0.01 & 0.01 & 0.02 & 0.00 \\
\hline Transport & 0.00 & 0.01 & 0.00 & 0.00 & 0.00 \\
\hline $\begin{array}{l}\text { Terrorism/political } \\
\text { violence }\end{array}$ & 0.02 & 0.01 & 0.01 & 0.01 & 0.01 \\
\hline $\begin{array}{l}\text { Instability in } \\
\text { employment }\end{array}$ & 0.01 & 0.01 & 0.01 & 0.00 & 0.00 \\
\hline Education problems & 0.05 & 0.05 & 0.04 & 0.03 & 0.02 \\
\hline Inflation/price rises & 0.04 & 0.05 & 0.04 & 0.06 & 0.05 \\
\hline Unemployment & 0.12 & 0.15 & 0.17 & 0.19 & 0.20 \\
\hline Lack of opportunities & 0.01 & 0.00 & 0.01 & 0.00 & 0.00 \\
\hline $\begin{array}{l}\text { Violation of human } \\
\text { rights }\end{array}$ & 0.01 & 0.00 & 0.00 & 0.00 & 0.00 \\
\hline Housing problems & 0.00 & 0.00 & 0.00 & 0.00 & 0.01 \\
\hline Health problems & 0.03 & 0.03 & 0.04 & 0.03 & 0.03 \\
\hline $\begin{array}{l}\text { Environmental } \\
\text { problems }\end{array}$ & 0.00 & 0.01 & 0.00 & 0.01 & 0.01 \\
\hline Corruption & 0.10 & 0.07 & 0.06 & 0.05 & 0.05 \\
\hline Drug trafficking & 0.00 & 0.01 & 0.01 & 0.00 & 0.00 \\
\hline Crime/public security & 0.26 & 0.24 & 0.23 & 0.19 & 0.14 \\
\hline Poverty & 0.02 & 0.02 & 0.03 & 0.04 & 0.03 \\
\hline Drugs consumption & 0.01 & 0.01 & 0.01 & 0.02 & 0.02 \\
\hline Political crisis & 0.08 & 0.07 & 0.06 & 0.04 & 0.04 \\
\hline $\begin{array}{l}\text { Distribution of } \\
\text { income }\end{array}$ & 0.02 & 0.01 & 0.01 & 0.01 & 0.01 \\
\hline $\begin{array}{l}\text { Economy/economic } \\
\text { problems }\end{array}$ & 0.07 & 0.09 & 0.08 & 0.08 & 0.08 \\
\hline $\begin{array}{l}\text { Deficient basic } \\
\text { services }\end{array}$ & 0.01 & 0.01 & 0.01 & 0.01 & 0.01 \\
\hline Violence, bands & 0.03 & 0.03 & 0.03 & 0.04 & 0.05 \\
\hline Other & 0.04 & 0.04 & 0.04 & 0.04 & 0.04 \\
\hline $\begin{array}{l}\text { Shortages/lack of } \\
\text { food }\end{array}$ & 0.03 & 0.03 & 0.03 & 0.02 & 0.02 \\
\hline No problem & 0.01 & 0.00 & 0.00 & 0.01 & 0.02 \\
\hline
\end{tabular}




\section{Chapter 4}

\section{The Impact of Inequality on Support for Preferential Trading Agreements in the US}

Income inequality in the United States increased during the past several decades, while at the same time the amount of money spent lobbying Congress also substantially increased. ${ }^{31}$ The majority of the US public views the US as economically unequal, believes interest groups have to great of an influence over policy, and views politicians as ignoring the preferences of their constituents. ${ }^{32}$ In this chapter I apply my theory of inequality and trade policy formation to the US, specifically trade agreement votes in the US Senate. I examine the influence of public opinion and interest group contributions on senators' votes on the Dominican Republic-Central America Free Trade Agreement (CAFTA-DR), the Peru Trade Promotion Agreement, the USColombia Trade Agreement, and the US-Korea Free Trade Agreement. I find evidence suggesting, contrary to my expectations and independent of interest group influence, the middle class may have the greatest influence over trade policy at all levels of inequality, while the influence of the upper class is lower at higher levels of inequality. In line with expectations, the results also provide evidence that influence from the lower class is lessened at higher levels of inequality. The results also point to senators' willingness to vote with the preferences of the interest groups who support them, whether these groups are for or against the policy, and regardless of the level of inequality.

\footnotetext{
31 The US Census Bureau estimates the Gini coefficient for the US in 1974 at 0.40 , and in 2014 at 0.48 . For the 1990 election cycle there were a total of \$369.41 million (in 2014 dollars $\$ 669.28$ million) in interest groups contributions reported to the Federal Election Commission, for the 2014 election cycle there was $\$ 2.26$ billion reported (Center for Responsive Politics 2016).

3231 percent of Americans see the wealth distribution in the US as fair (Newport 2015). 69 percent of Americans say most members of Congress are focused on the needs of special interests, while 25 percent say Congress is focused on the needs of constituents (Dugan 2015).
} 


\section{Increasing Inequality in the US}

Much of the increase in inequality in the US can be attributed to technological change; with technology improving the productivity of skilled workers while simultaneously providing direct competition to unskilled workers, meaning workers are increasingly competing at the global level (Acemoglu 2002; Acemoglu 2003; Jaumotte et al. 2013; Berman et al. 1998; Kurokawa 2011). Trade and globalization have contributed to outsourcing which, in turn, has helped to increase inequality in developed states (Berman et al. 1998). The Stolper-Samuelson Theorem states, when a capital abundant country opens up to trade with a labor abundant country the skilled workers in the capital abundant economy will benefit, while the unskilled workers in the capital abundant country will be harmed (Stolper and Samuelson 1941; Wood 1997). This occurs because the capital abundant country has a relatively high number of skilled workers, and the capital scarce country has a relatively low number of skilled workers. When the countries begin to trade with one another, the demand for the labor of skilled workers increases because the skilled workers for the capital abundant state can now offer the products of their labor in a market that has few skilled workers, increasing the overall demand for their labor. The opposite occurs for the unskilled workers in the capital abundant country. As the more capital abundant country opens up to trade with the more labor abundant country, the unskilled workers in the capital abundant country become relatively abundant because they now must compete with more unskilled workers. Therefore, skilled workers in a capital abundant economy have a strong incentive to be in favor of free trade, while unskilled workers face increased competition from free trade, both from foreign workers and from technology, incentivizing them to be against trade. Dutt and Mitra (2002) do find support that this is the case, finding inequality increases protectionism in capital abundant states. 
There is the possibility that as inequality increases, which usually translates to an increased number of workers with relatively lower incomes, protectionism increases. Workers at the lower end of the pay scale will demand increased protectionism and, as the number of these workers increase with inequality, the pressure on politicians to implement trade protections increases. This certainly could be the case for the agreements I examine. Overall, support among the public for the agreements I examine increases fourteen points moving from the lowest to the highest class group. ${ }^{33}$ However, as discussed in the literature review, what is currently missing is a way to connect the public's trade preferences to the policy outcomes. The skilled and unskilled groups of workers have conflicting economic interests, and I argue the skilled workers, who see their incomes increase relative to unskilled workers in a globalized world with increased trade are likely to win out because of the amount of resources they control.

\section{Hypotheses}

My theory in the proceeding chapter is based on three assumptions. First, individuals have preferences and will support the candidate they expect will best represent their preferences. Second, politicians want to win elections (Mayhew 2004). Third, financial resources (among others) increase a candidate's probability of being elected (Sudulich et al. 2013). Therefore, politicians and interest groups will seek each other out, politicians will seek out interest group support, particularly their monetary support, and interest groups will seek out politicians to support their policy preferences.

\footnotetext{
${ }^{33}$ Using the Cooperative Congressional Election Study (CCES), which asks respondents if they support or oppose legislation that has been considered in Congress during the past two years. The CCES asked for respondents' opinion on three different trade agreements: in 2006 and 2007 they asked about the Dominican Republic-Central America Free Trade Agreement (CAFTA-DR); in 2008 they asked about extending NAFTA to Peru and Colombia; and in 2012 they asked about the South Korean Free Trade Agreement.
} 
When there is low economic inequality, individuals have approximately the same amount of resources and because they can expend similar amounts of resources on the political process, they have a relatively equal chance of influencing outcomes (Goodin and Dryzek 1980). Therefore, when there is low economic inequality, candidates will appeal to a wide range of voters, making a candidate's preferences more representative of constituent preferences. Interest groups will still have influence, but that influence will be tempered by an engaged constituency, who are encouraged via their ability for their preferences to become policy. When economic inequality is high resources become increasingly concentrated among the wealthy, and politicians will have to appeal only to a relatively small group of individuals to gain the resources needed for election. Therefore, politicians' preferences will reflect the preferences of a smaller, wealthier group of constituents; that is, they will reflect the preferences of those who provide them with the most benefit.

Politicians may first adopt the preferences of the wealthy, who can provide them with the greatest support, and then make the argument to the rest of the population that the policies the wealthy prefer will benefit everyone, ignoring the existing preferences of the poor (Rigby and Wright 2013). Rigby and Wright (2013) find, when it comes to US party platforms, the two major parties include the economic preferences of those who are more well-off and ignore the preferences of those at the bottom. They do find, when it comes to social policy, both parties include the social policy preferences of the poor in their platforms. However, this is likely the result of the poor largely sharing social policy preferences with other income groups. For example, the Republican Party has adopted economic policies that largely benefit the wealthy and promoted them as beneficial to the overall economy, i.e. tax cuts for those with high incomes, while also adopting a social policy platform with appeal across income groups. While 
tax cuts for the wealthy can provide overall growth in the economy through giving the wealthy more income to spend and invest, and thus stimulate economic growth, they are a direct benefit to the wealthy. The alternative would be to provide the bulk of the tax cuts to those who are less well off, providing them with a direct benefit and still having increased economic growth as more money would be available to spend and invest in the economy. Greater inequality means those at the bottom have fewer relative resources to try and establish and voice their own preferences. When it comes to the formation of trade policy, the likely case is that the wealthy are listened to by elected officials and their preferences are then sold to the rest of the population.

In the US, the president negotiates treaties and the Senate ratifies them, except in the case of fast tracking when Congress first authorizes the president to negotiate a treaty, and then approves the agreement with a simple majority in both chambers of Congress. ${ }^{34}$ Senators are elected at the state level; therefore, I expect inequality in a senator's state to determine how much constituents and interest groups influence senators' preferences. While senators do face pressure from national forces they are ultimately accountable to those who elect them. Furthermore, when there is greater inequality in a state, e.g. more people with relatively low incomes, this will provide a greater opportunity for interest groups, particularly business interest groups, to influence policy. Whether these groups are from inside or outside the state is irrelevant; the public within a state not having enough relative resources to push back against interest groups allows these groups to assert their preferences within a state. While the president is chiefly responsible for negotiating trade policy, trade policy approval is ultimately left up to

\footnotetext{
${ }^{34}$ The Peru, Columbia, and Korea agreements and CAFTA-DR were all negotiated under fast track, these agreements still faced final approval by the Senate and senators faced the same pressures as they would when approving an agreement that was not negotiated under fast track. Ideally, more agreements would be examined, including ones not negotiated under fast track. However, as Ehrlich (2018) notes, fast track has become the norm, and under fast track the US has entered into agreements with a variety of countries. While I am only able to examine four agreements because of limited public opinion data, as noted above, the agreements I do examine are with a variety of countries, making them representative of the agreements the US enters into.
} 
the Senate, or in the case of fast track, the House and the Senate. This give senators, and in turn those who are able to influence their preferences, final say over policy. ${ }^{35}$

Table 1 shows the inequality across the US and the average level of inequality across US states as measured by the Gini coefficient for each year included in the analysis. Depending on the source of the inequality estimate for the country level, inequality averaged across US states is either slightly lower, or slightly higher, than inequality in the US. There is not a huge amount of

\begin{tabular}{|c|c|c|c|}
\hline & 2005 & 2007 & 2011 \\
\hline Mean State Gini & 0.447 & 0.450 & 0.457 \\
\hline Std. Dev. of State Gini & 0.020 & 0.020 & 0.020 \\
\hline Min. State Gini & 0.406 & 0.409 & 0.408 \\
\hline Max. State Gini & 0.496 & 0.500 & 0.503 \\
\hline $\begin{array}{l}\text { United States Gini (US Census Bureau } \\
\text { Estimate) })^{37}\end{array}$ & $0.466^{38}$ & 0.467 & 0.475 \\
\hline United States Gini (World Bank Estimate) & $40.6^{39}$ & 41.8 & $40.5^{40}$ \\
\hline
\end{tabular}

variation in inequality among US states; the Gini coefficient has a range of only about 0.1 among US states. Therefore, in addition to using the Gini coefficient as a measure of inequality, I also rank each state from most to least equal based on Gini. Given that senators who are elected at the state level have the final say on trade policy, if average inequality across US states is lower than overall inequality in the US the public will have greater influence on trade policy than would be expected from looking at country level inequality. However, if inequality averaged across the states is higher than inequality in the US the public will have less influence than expected. This also provides a possible reason why trade policy could stray from national

\footnotetext{
${ }^{35}$ Ideally influence on the votes of House members would also be examined, but data limitations preclude this from occurring.

${ }^{36}$ Gini coefficient data for 2007 and 2011 from US Census Bureau, data for 2005 from Hisnanick and Rogers (2006)

${ }^{37}$ The mean of state Gini is slightly lower that the Gini for the US as a whole. This shows that individual states are slightly more equal within themselves than the country as a whole.

${ }^{38}$ From Hisnanick and Rogers (2006)

${ }^{39}$ Estimate is from 2004, 2005 data on Gini is not available from the World Bank

${ }^{40}$ Estimate is from 2010, 2011 data on Gini is not available from the World Bank
} 
preferences; inequality at the state level is distorting influence. Therefore, the structure of the Senate and state level inequality, as discussed in the previous paragraph, will affect trade policy outcomes, something a cross-country analysis would neglect. This leads to the first two hypotheses:

H1: The higher the economic inequality in a state, the more the trade preferences of a senator from that state will reflect the trade preferences of high-income individuals.

H2: The higher the economic inequality in a state, the less the trade preferences of a senator from that state will reflect the trade preferences of middle and lower income individuals.

At high levels of inequality the public is expected to be disengaged, giving interest groups more opportunity to assert their preferences, while at low levels of inequality the public is expected to be more engaged. Through political engagement both the public and interest groups hope to influence policy, and those with a greater amount of relative resources will find it easier to be engaged and to influence policy. Senators will represent the public's interests, but will only do so when they have an incentive to do so; if the public is not providing benefits to them, through support, they will look for support elsewhere. Interest groups have narrow agendas and will support politicians who support their agenda (Balla 2000). When a large part of the population becomes disengaged on an issue, interest groups are able to take advantage of this to insert their own agenda. ${ }^{41}$ Politicians are able to benefit from this lack of public interest and can instead support the policies of interest groups (Bawn et al. 2012).

In exchange for a candidate supporting their agenda, an interest group can provide support to a candidate by appealing to voters on a candidate's behalf, and provide the candidate

\footnotetext{
${ }^{41}$ I expect senators to solicit more contributions from interest groups when inequality is high, because they will be able to adopt the preferences of these groups in exchange for these contributions, and for interest groups to seek out senators to give to who support their position when inequality is high, because they will see more of an opportunity to influence policy outcomes.
} 
with campaign funds (Grossman and Helpman 2002). Since constituents will have more pressing concerns at a high level of inequality, such as providing for their basic needs, or gaining more education, or any number of other concerns, they will not be aware enough to provide effective retaliation at the voting booth for a candidate straying from their preferences. However, trade can be made a central issue by politicians who see incumbents straying from constituents' trade preferences. This gives politicians an incentive to abide by the trade preferences of their constituents, even if constituents do not always vote on these preferences.

Only interest groups who stand to benefit or be harmed from trade policy will lobby for their trade policy preferences. When trade policy is formed, interest groups who have supported politicians in the past will have their interests represented in exchange for their support. However, increased influence at high levels of inequality will occur only for business and industry groups, while labor groups will be left out because their members have relatively low incomes and will be less engaged as inequality increases. Labor unions will still have money and votes at higher levels of inequality, however, because they rely on funding from their members as inequality increases, as the relative incomes of union members decrease, their funding relative to business interest groups will decrease. Additionally, because people with lower incomes are less likely to vote, as inequality increases and those in unions receive relatively less pay, their income will effectively decrease, and they will become less likely to vote. As campaigns become larger and more expensive to run, or as inequality increases, this will mean increasing reliance on business interest groups for funding. Therefore, the third and fourth hypotheses are:

H3: The greater the economic inequality in a state, the more the trade preferences of a senator from that state will reflect the trade preferences of business and industry interest groups. 
H4: The greater the economic inequality in a state, the less the trade preferences of a senator from that state will reflect the trade preferences of labor groups.

\section{Research Design}

In order to determine what influence public opinion has on free trade agreement outcomes, public opinion on specific trade agreements needs to be determined. The Cooperative Congressional Election Study (CCES) asks respondents if they support or oppose legislation that has been considered in Congress in the past two years. The CCES asked for respondents' opinion on three different trade agreements: in 2006 and 2007 they asked about the Dominican Republic-Central America Free Trade Agreement (CAFTA-DR); in 2008 they asked about extending NAFTA to Peru and Colombia; and in 2012 they asked about the South Korean Free Trade Agreement. ${ }^{42}$ The US did not enter into a free trade agreement with Peru and Colombia, but entered into separate bilateral trade agreements with each of them, with Peru in 2007 and with Colombia in 2011, there was no vote on whether or not to extend NAFTA to Peru and Colombia, and instead there were separate votes on agreements with Peru and Colombia. Thus, four trade agreements will be examined, CAFTA-DR, the Peru Trade Promotion Agreement, the US-Colombia Trade Agreement, and the US-Korea Free Trade Agreement. Table 2 gives a summary of the votes on these four agreements. ${ }^{43}$

Table 2: Outcomes of Votes in Senate

\begin{tabular}{lcccc}
\hline & Yes & No & Not Voting & Date of Vote \\
\hline CAFTA-DR & 55 & 45 & 0 & 28 July 2005 \\
Peru Agreement & 77 & 18 & 5 & 4 Dec. 2007 \\
Colombia Agreement & 66 & 33 & 1 & 12 Oct. 2011 \\
Korea Agreement & 83 & 15 & 2 & 12 Oct. 2011 \\
\hline
\end{tabular}

\footnotetext{
42 Only 10,000 respondents were asked in 2007 while 36,217 were asked in 2006, therefore 2006 will be used.

${ }^{43}$ The four agreements were negotiated under fast track and therefore only needed a simple majority in each chamber to pass.
} 
Ideally, a wider range of agreements would be examined to get more variation in the type of agreement (bilateral versus multilateral) as well as geographic variation. However, while this is not a random sample of agreements, they do provide a variety of trade policies, including bilateral agreements and a multilateral agreement, and agreements with countries of varying levels of wealth and development. ${ }^{44}$ The other issue with this case selection is that there is no null case - a trade agreement that did not pass - however there is no recent case of a trade agreement being negotiated and sent to the Senate and then not being ratified ${ }^{45}$ Presidents are unlikely to want to commit resources to negotiating a trade agreement they know are very unlikely to be ratified, or, as was the case with the Free Trade Area of the Americas, those for which negotiations could break down before the agreement reaches the point of ratification. There are no specific expectations of Senators varying their votes on these agreements because these are general free trade agreements not focused on any specific good or service, therefore the public and interest groups are expected to assert similar pressures on each agreement.

\section{Dependent Variable}

The votes of senators on CAFTA-DR, the Peru Trade Promotion Agreement, the USColombia Trade Agreement, and the US-Korea Free Trade Agreement will be used as the dependent variable in each model ${ }^{46}$ CAFTA-DR was voted on in 2005, the Peru Trade Promotion Agreement in 2007, the US-Colombia Trade Agreement in 2011, and the US-Korea

\footnotetext{
${ }^{44}$ Korea is a high-income country; Colombia, Peru, Costa Rica, and the Dominican Republic are middle-income income countries; El Salvador, Guatemala, Honduras, and Nicaragua are lower-middle-income countries. This is according to the World Bank's definition of low to high-income countries. The World Bank's classification of countries is by GNI per capita in US dollars, low-income (GNI per capita $<\$ 1,045$ ), lower middle income (GNI per capita $\$ 1,046$ to $\$ 4,125$ ), upper-middle-income (GNI per capita $\$ 4,126$ to $\$ 12,735$ ), high-income (GNI per capita > $\$ 12,736)$.

${ }^{45}$ The last case of the Senate not ratifying an agreement was in 1870 , when the Senate did not ratify a reciprocity agreement with Hawaii (US Senate 2017).

${ }^{46} \mathrm{Fast}$ track authorization occurred for all of these agreements in 2002, ideally this vote on fast track would also be looked at, however data are not available for the public's preferences on fast track trade legislation.
} 
Free Trade Agreement in 2011. ${ }^{47}$ Data on senators' votes comes from the Library of Congress.

Votes will be coded as 0 if a senator voted against a policy, and 1 if they voted in favor.

Summary statistics for all variables are located in Table 3.

\section{Independent Variables}

Public Opinion on Trade by Income

To obtain public opinion on trade agreements by income category, multilevel regression and poststratification (MRP) in conjunction with the American Community Survey (ACS) from the US Census bureau and the CCES was used. In 2006 the CCES asked respondents about their support for CAFTA-DR, in 2008 they asked about support for extending NAFTA to Peru and Colombia, and in 2012 they asked respondents if they supported or opposed the Korean free trade agreement. The proportion of respondents in the CCES who said they would have voted for these policies, adjusted using MRP, will be used to measure public opinion on the agreements. The response to extending NAFTA to Peru and Colombia will be used for both the vote on the Peru agreement and the vote on the Colombia agreement. Ideally, public preferences on the Peru and Colombia agreements would be known, but the public's preferences were not asked regarding joining these agreements. No question in the CCES asked directly about joining the US-Peru Trade Promotion Agreement or the US-Colombian Trade Promotion agreement, so the question on extending NAFTA is the best proxy. The question on extending NAFTA to Peru and Colombia was asked at a time when there was a proposal in Congress to extend NAFTA to Peru and Colombia; this proposal was never voted on. However, there were votes on entering into bilateral trade agreements with Peru and Colombia, and these will be used instead.

\footnotetext{
${ }^{47}$ For procedural reasons CAFTA-DR was voted on twice, once on 6-30-2005 and again on 7-28-2005. This was the same bill, no senators changed their votes and only one additional senator voted during the second vote, therefore little additional variation would be gained by including both votes. Only the second vote will be included in the analysis.
} 
The CCES is only representative at the national level, and not the state level. While the survey does ask 30,000+ respondents in a given year, in some states less than a hundred respondents are asked during the years used. These numbers are lower when survey respondents are broken down into income categories. MRP is used to match the demographic characteristics in a geographic area, in this case states with the demographic characteristics of nonrepresentative survey data, in order to make the survey data more representative at the lower Table 3: Percent of People in Each Family Income Category by State (using American Community Survey)

\begin{tabular}{|c|c|c|c|}
\hline & 2006 & 2008 & 2012 \\
\hline Lower Class (below $\$ 30,000$ ) & 26.50 & 24.27 & 25.08 \\
\hline Lower Middle Class ( $\$ 30-000$ to $\$ 69,999$ ) & 35.66 & 33.94 & 31.94 \\
\hline Upper Middle Class $(\$ 70,000$ to $\$ 149,999)$ & 27.27 & 29.47 & 27.83 \\
\hline Upper Class $(\$ 150,000 \text { and above })^{48}$ & 10.58 & 12.33 & 15.15 \\
\hline
\end{tabular}

geographic level. Demographic characteristics by state come from the ACS. ${ }^{49}$ Demographic characteristics that were matched on are gender, education, family income, and age. Appendix 1 shows how the demographic characteristics of the ACS were matched to the CCES. State level control variables used when obtaining estimates using MRP were the share of the populace that voted Democrat in the last presidential election, economic inequality, and the percent of workers in a union. ${ }^{50}$

Income categories were broken down into lower class, lower middle class, upper middle class, and upper class. Table 3 shows the breakdown of these categories and the percentage of people in each state in these categories. In all years the largest category is the lower middle class, and the smallest category is the upper class. Therefore, if each individual has the same amount of influence the class with the greatest number of people should have the greatest

\footnotetext{
${ }^{48}$ Ideally a family income category above $\$ 150,000$ would be used to capture the very wealthy, however above $\$ 150,000$ is the top family income category available across the ACS and CCES.

${ }^{49}$ ACS data for $1 \%$ of the population used. Data from IPUMS database, Ruggles et al. 2015.

${ }^{50}$ Democratic vote share from the American Presidency Project, inequality is measured using Gini with data from the US Census Bureau, data on union membership is from the US Bureau of Labor Statistics.
} 
amount of influence, meaning the lower middle class should have the greatest amount of influence, and the upper class the least.

Table 4: Percent in Favor of Each Agreement by Income Category using MRP Estimates ${ }^{51}$

\begin{tabular}{lccc}
\hline & $\begin{array}{c}\text { CAFTA-DR } \\
(2006)\end{array}$ & $\begin{array}{c}\text { Expanding NAFTA to Peru and } \\
\text { Colombia (2008) }\end{array}$ & Korea (2012) \\
\hline Percent Lower Class in Favor & 37.40 & 32.32 & 75.43 \\
Percent Lower Middle Class in Favor & 39.46 & 33.10 & 76.33 \\
Percent Upper Middle Class in Favor & 48.11 & 37.99 & 79.54 \\
Percent Upper Class in Favor & 61.73 & 46.79 & 84.43 \\
Percent of Public in Favor & 43.63 & 27.75 & 78.21 \\
\hline
\end{tabular}

Table 4 shows the breakdown of support for each agreement by income category using MRP estimates. Across all agreements the upper class showed the greatest support while the lower class showed the least amount of support. The expectation is when inequality is higher in a state the upper class will have greater influence than when inequality is low in a state. The influence of those in the other income categories decreases when moving from low to high inequality. For the models, each class group is separated from the population and then the percentage of each group in favor of an agreement is taken; therefore, the percentages of each class group that is in favor of an agreement are not related to one another, meaning no baseline category is needed.

\section{Interest Group Preferences}

The Federal Election Commission keeps track of campaign contributions to senators from all sources, including interest groups. The Center for Responsive Politics (CRP) aggregates the data on campaign contributions to senators reported to the Federal Election Commission. The CRP aggregates contributions from various types of interest groups, such as livestock groups, alternative energy groups, social issues groups, etc. Appendix 2 explains how interest groups are

\footnotetext{
${ }^{51}$ These estimates are biased because the state level data used was only representative at the state level, and not representative by income. This is especially a problem for presidential vote share for the Democrat and union membership because these vary significantly with income.
} 
classified by the CRP. Contributions from business and industry groups given during the election cycle in which the trade agreement was passed will be aggregated into two groups. ${ }^{52}$ Appendix 3 includes the main areas of coverage for each of the four agreements. Each of the four agreements are similar in their coverage, therefore contributions were grouped the same way for each of the four agreements.

Contributions from the CRP classification of groups who represent agribusiness, communications/electronics, energy and natural resources, finance, insurance and real estate, health, and transportation were included as in favor of the agreement because these groups were expected to benefit from the agreement through greater market access. While this large grouping could miss some disagreements between these groups on policy, because what is of concern is the overall influence of business interest groups, these groups are aggregated together. The expectation is that the greater the amount of money these groups donate to a senator, the more likely the senator will be to vote in favor of the agreement. The groups from the CRP classification expected to be against the agreement were labor groups since these groups represent workers who are expected to be harmed by these agreements.

Despite these agreements making labor standards more consistent across the countries party to the agreement, the workers represented by labor unions in the US are expected to be less competitive under these agreements. This is because the US is a relatively skill abundant country compared to other countries in these agreements, who are relatively labor abundant compared to the US. ${ }^{53}$ Lower skilled workers in the US are relatively scarce, this allows them to demand relatively more for their labor than lower skilled workers in countries that have

\footnotetext{
${ }^{52}$ CRP aggregated Senator data every six years, therefore contribution aggregates for 2001-2006, 2003-2008, and 2007-2012 are used.

${ }^{53}$ The Latin American states included in these agreements are much more labor abundant than the US, while Korea only has a slightly lower cost of labor than the US.
} 
relatively abundant low skilled labor. This is because the relative abundance of lower skilled workers in labor abundant countries pushes wages down for low skill workers in these countries compared to the US; therefore, when the US opens up to trade with these countries lower skilled workers face downward pressure on their wages from workers who have the same skill level and are paid less. The expectation is that the greater the amount of contributions to a senator from labor unions, the less likely the senator will be to vote in favor of the agreement.

Interest group contributions are aggregated into two different groups by CRP:

contributions given to a senator's official campaign committee to assist directly with their election, and contributions given to a senator's leadership PAC. ${ }^{54}$ These categories are totaled and used in the same variable because both of these categories of contributions assist a senator with their reelection goal. Contributions to a senator's campaign committee assists them directly with their reelection, while contributions to their leadership PAC allows them to contribute to other senators. Leadership PAC funds therefore help with the member's standing in the Senate. ${ }^{55}$ Interest group contributions are reported in millions.

\section{Inequality}

The Gini coefficient is used to measure economic inequality. The coefficient is a measure of income inequality in an area, based on how concentrated earnings are among the populace, and given as a proportion. Gini ranges from zero to one; a Gini of zero indicates no income inequality in an area, that is to say everyone has the same income, while a Gini of one indicates perfect income inequality in an area. My theory relies on changes in the overall

\footnotetext{
${ }^{54} \mathrm{~A}$ leadership PAC is money that politicians can use to assist other politicians with reelection, thus politicians can use their leadership PAC to potentially influence other politicians and gain their support.

${ }^{55}$ Dodd (1977) argues members of Congress do have reelection as their top priority, but they also want power, and one of the ways to achieve power is through committee assignments and members need support in the party to get the most coveted assignments.
} 
distribution of income in a population, rather than on how much income a given segment of the population has. Because the Gini coefficient measures overall inequality in an area, the Gini coefficient is ideal for measuring income inequality in this case. Data on inequality comes from the US Census Bureau.

To determine variation in influence on income inequality senators were broken into two groups, those from high income inequality states and those from low income inequality states, the models were also run with all states. High and low income inequality was determined by taking the mean Gini for each year. States above the mean were classified as high inequality, while states below the mean were classified as low inequality, with this done for each year a trade agreement was voted on. To determine if influence from the public and interest groups changes with inequality, results for the high and low categories will then be compared to one another.

There is also the issue that Gini varies relatively little from state to state. For all years examined Gini spans a little less than 0.1 from the state with the lowest inequality to the state with the highest inequality. Globally Gini has a range of $0.3 .{ }^{56}$ Because of the relatively low variation in the Gini coefficient among US states, in order to get greater variation in inequality an additional measure of inequality was used. States were ranked 1-50 with 1 being the least unequal, and 50 being the most unequal. This ranking was done for each year. States were again broken down into high and low categories in order to measure variation in influence from the public and interest groups; states were split at the halfway point, with states ranked 1-25 being placed in the low inequality group and states ranked $26-50$ being placed in the high inequality group.

\footnotetext{
${ }^{56}$ Based on 2010 Gini coefficient estimates from the World Bank World Development Indicators, data were available for 78 countries.
} 
For both measures of inequality, Gini and inequality ranking using Gini, states would ideally be broken down further into categories, however this would create a low N problem. Given that the difference between the means for the Gini coefficient for the high and low categories is 0.04 there is not a huge difference between these two categories. However, the additional use of ranking inequality helps to increase this variation.

\begin{tabular}{|c|c|c|c|c|c|c|c|c|c|c|c|c|}
\hline & \multicolumn{4}{|c|}{ All } & \multicolumn{4}{|c|}{ Low Inequality } & \multicolumn{4}{|c|}{ High Inequality } \\
\hline & Mean & $\begin{array}{l}\text { Std. } \\
\text { Dev. }\end{array}$ & Min. & Max. & Mean & $\begin{array}{l}\text { Std. } \\
\text { Dev. }\end{array}$ & Min. & $\operatorname{Max}$. & Mean & $\begin{array}{l}\text { Std. } \\
\text { Dev. }\end{array}$ & Min. & Max. \\
\hline $\begin{array}{l}\text { Senator Vote in Favor } \\
\text { of Agreement }\end{array}$ & 0.70 & 0.46 & 0 & 1 & 0.67 & 0.47 & 0 & 1 & 0.73 & 0.45 & 0 & 1 \\
\hline $\begin{array}{l}\text { Percent Lower Class in } \\
\text { Favor of Agreement }\end{array}$ & 55.14 & 20.47 & 28.85 & 79.17 & 53.88 & 20.54 & 30.00 & 79.17 & 56.20 & 20.40 & 28.85 & 77.51 \\
\hline $\begin{array}{l}\text { Percent Lower Middle } \\
\text { Class in Favor of } \\
\text { Agreement }\end{array}$ & 56.30 & 20.26 & 29.81 & 79.42 & 54.85 & 20.36 & 30.65 & 79.42 & 57.52 & 20.14 & 29.81 & 78.53 \\
\hline $\begin{array}{l}\text { Percent Upper Middle } \\
\text { Class in Favor of } \\
\text { Agreement }\end{array}$ & 61.29 & 18.70 & 34.61 & 82.16 & 59.72 & 18.87 & 35.52 & 82.16 & 62.60 & 18.50 & 34.61 & 81.91 \\
\hline $\begin{array}{l}\text { Percent Upper Class in } \\
\text { Favor of Agreement }\end{array}$ & 69.34 & 16.08 & 43.27 & 87.02 & 68.12 & 16.25 & 44.43 & 87.02 & 70.36 & 15.91 & 43.27 & 85.83 \\
\hline $\begin{array}{l}\text { Total Contributions } \\
\text { in Favor }\end{array}$ & 3.77 & 2.60 & 0 & 17.48 & 3.13 & 2.10 & 0 & 11.81 & 4.31 & 2.86 & 0.07 & 17.48 \\
\hline $\begin{array}{l}\text { Total Contributions } \\
\text { Against }\end{array}$ & 0.21 & 0.23 & 0 & 1.09 & 0.21 & 0.23 & 0 & 1.06 & 0.21 & 0.22 & 0 & 1.09 \\
\hline $\begin{array}{l}\text { Inequality (Gini } \\
\text { Coefficient) }\end{array}$ & 0.45 & 0.02 & 0.41 & 0.50 & 0.43 & 0.01 & 0.41 & 0.45 & 0.47 & 0.01 & 0.45 & 0.50 \\
\hline $\begin{array}{l}\text { Member of President's } \\
\text { Party }\end{array}$ & 0.53 & 0.5 & 0 & 1 & 0.52 & 0.50 & 0 & 1 & 0.53 & 0.50 & 0 & 1 \\
\hline No High School & 0.13 & 0.04 & 0.08 & 0.22 & 0.11 & 0.02 & 0.08 & 0.17 & 0.15 & 0.03 & 0.10 & 0.22 \\
\hline High School & 0.30 & 0.04 & 0.21 & 0.42 & 0.30 & 0.03 & 0.24 & 0.37 & 0.30 & 0.04 & 0.21 & 0.42 \\
\hline $\begin{array}{l}\text { Associates/Some } \\
\text { College }\end{array}$ & 0.29 & 0.04 & 0.22 & 0.38 & 0.31 & 0.04 & 0.24 & 0.38 & 0.27 & 0.03 & 0.22 & 0.35 \\
\hline College & 0.27 & 0.05 & 0.17 & 0.39 & 0.28 & 0.04 & 0.21 & 0.37 & 0.27 & 0.05 & 0.17 & 0.39 \\
\hline Mean Income & 6.54 & 1.07 & 4.47 & 9.27 & 6.59 & 0.91 & 5.01 & 9.09 & 6.49 & 1.19 & 4.47 & 9.27 \\
\hline $\begin{array}{l}\text { Exports to Country(ies) } \\
\text { in Agreement }\end{array}$ & 10.19 & 15.95 & 0 & 90.76 & 7.95 & 16.87 & 0 & 90.76 & 12.05 & 14.93 & 0.08 & 71.19 \\
\hline
\end{tabular}

Groups against the agreements (labor groups) are expected to have greater influence on senators' votes in the low inequality group, while business interest groups are expected to have more influence in the high inequality group. The upper class' preferences are expected to have greater influence in high income inequality states, while the preferences of those in the other income categories are expected to have greater influence in the low inequality states.

Table 5 has summary statistics for the dependent, independent, and control variables when the Gini coefficient is used, and states were classified as high and low based on the mean 
of Gini. Table 6 has summary statistics for the dependent variable, and the independent and control variables when inequality ranking was used, and states were split into the first and second twenty-five.

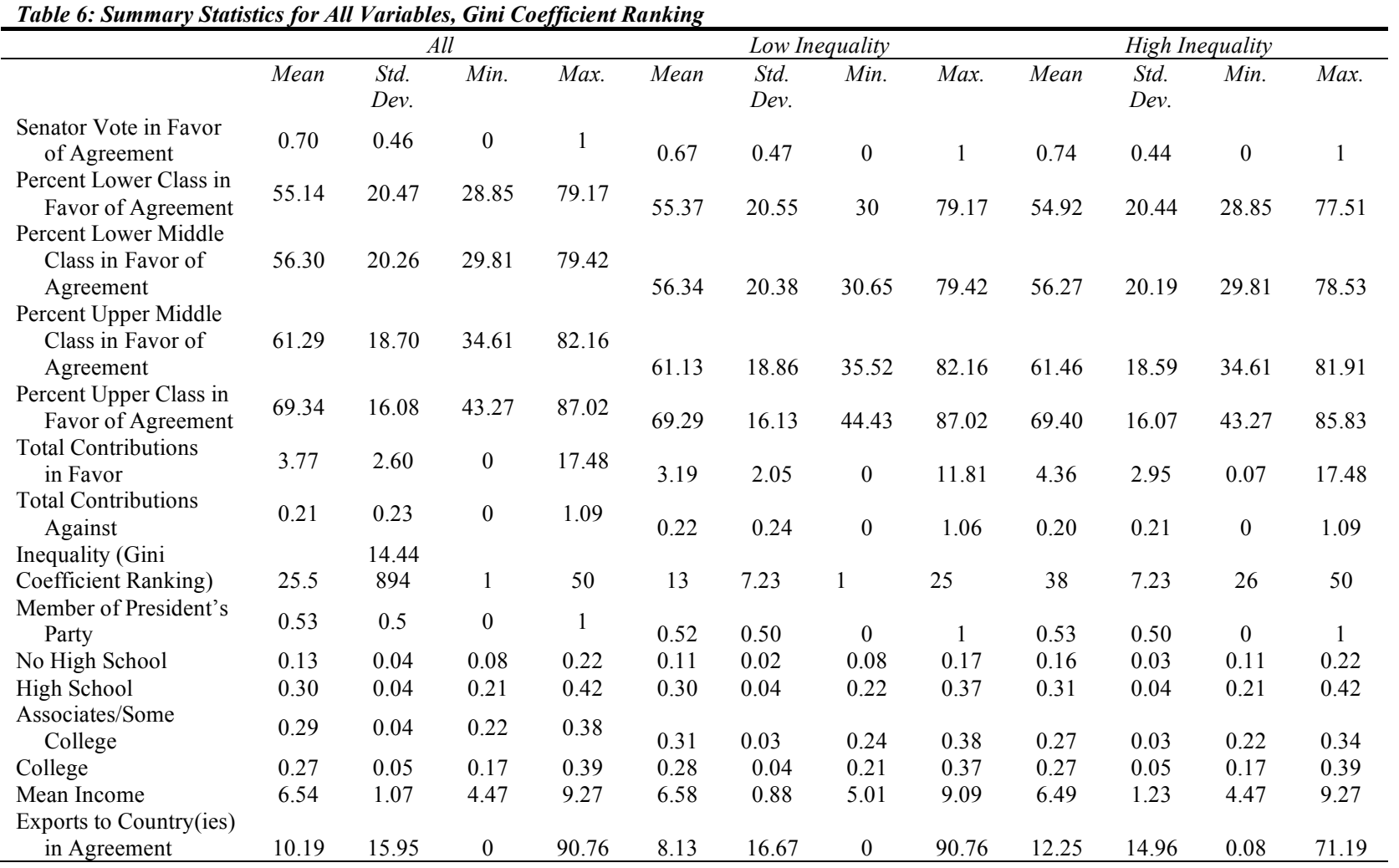

\section{Control Variables}

Senators from the president's party will want the president to win on an issue, while senators from the opposing party will want to prevent them from accomplishing their goals. Therefore, a senator being in the president's party is controlled for. Senators are coded as 1 if they are in the president's party and 0 if they are not. Senators in the president's party are expected to be more likely to vote for a trade deal.

Hainmueller and Hiscox (2006) find a positive relationship between years of education and favorability towards trade policy and find only a college education has a positive impact on an individual's favorability towards trade. While Ehrlich (2018) finds MOCs from districts with 
highly educated constituents tend to be more in favor of free trade. Those with more education are better equipped to compete when there is trade openness. Education is controlled for with four variables: proportion of the state's population with less than a high school diploma, proportion of the state's population with a high school diploma, proportion of the state's population with some college education or an associate's degree, and proportion of the state's population with a bachelor's degree or higher. The proportion of the state's population with some college education or an associate's degree is used as the baseline category. I expect that the higher the percentage of college graduates in a state the more likely a senator will be to vote in favor of a trade policy, while the higher the percentage in the other three education groups, the lower the likelihood of a senator voting in favor of a trade policy. Data on education comes from the US Census Bureau.

High skilled workers are generally paid more because they are relatively scarce, which pushes their wages up. High skilled workers in the US are relatively abundant compared to the rest of the world, this means when the US opens up to trade, these workers become relatively scarce on the global labor market and are able to demand higher wages. Skilled workers tend to have higher wages, therefore those with higher incomes are expected to be more in favor of free trade. The US has a higher level of human capital than the states these agreements are with; therefore, when the US opens up to trade with these states, it means higher skilled individuals will be in greater demand and their incomes will increase. Consequently, the higher an individual's income the more likely they are expected to be in favor of increased trade openness. The average family income in a state is used as the control for income because income in a household is generally shared. These data come from the US Census Bureau. Mean income is in ten-thousands. 
Malcolm (2017) finds that as the exports from a MOC's state to the country or countries in a potential trade agreement increases, a MOC is more likely to vote in favor of the agreement. These results are consistent with the idea that MOCs want to provide benefits to their constituents in order to increase their chances of being reelected, helping to increase a state's exports is one way to provide economic benefits. I include a variable for exports from a senator's state to the country or countries in each agreement as a percent of a state's GDP. This variable is lagged to the year before the vote on the agreement, the expectation being senators will be referencing how much their state has exported to the country in the past in order to determine the potential to increase future exports. Data on state exports are from the International Trade Administration and data on state GDP are from the Bureau of Economic Analysis, both these organizations are part of the US Department of Commerce.

Finally, dummies for trade policies are included to control for potential effects specific to each agreement, with Colombia used as the base category. Additionally, the model is run with each individual agreement. The model, which will be run with logit and used to estimate predicted probabilities, is:

Senator trade vote $=\alpha+\beta_{1}$ lower class in favor $+\beta_{2}$ lower middle class in favor $+\beta_{3}$ upper middle class in favor $+\beta_{4}$ upper class in favor $+\beta_{5}$ total contributions in favor $+\beta_{6}$ total contributions against $+\beta_{7 \text { inequality }}+\beta_{8}$ president's party $+\beta_{9} \%$ no high school diploma + $\beta_{10} \%$ high school diploma $+\beta_{11} \%$ college $+\beta_{12}$ income $+\beta_{13}$ exports to country(ies) in agreement $+15_{14}$ CAFTA-DR agreement dummy $+\beta_{15}$ Peru agreement dummy $+\beta_{16}$ Korea agreement dummy

\section{Results}

Table 7 gives the results for the model including all states, low income inequality states and high income inequality states, using Gini as the measure of inequality. Across all groups, interest groups contributions in favor of the agreement and against the agreement are significant at the $\mathrm{p}<0.01$ level or higher, and the signs are in the expected positive direction for groups in 
Table 7: Results for All States, and High and Low Inequality States Using Gini Coefficient to Measure Inequality ${ }^{57}$

\begin{tabular}{|c|c|c|c|}
\hline & All & Low Inequality & High Inequality \\
\hline Percent Lower Class in Favor of Agreement & $\begin{array}{l}-0.29 \\
(0.52)\end{array}$ & $\begin{array}{c}0.88 \\
(0.75)\end{array}$ & $\begin{array}{l}-2.41^{*} \\
(1.07)\end{array}$ \\
\hline Percent Lower Middle Class in Favor of & 0.18 & $-2.43^{*}$ & $3.13^{\circ}$ \\
\hline Agreement & $(0.81)$ & $(1.21)$ & $(1.67)$ \\
\hline Percent Upper Middle Class in Favor of Agreement & $\begin{array}{c}0.40 \\
(0.63)\end{array}$ & $\begin{array}{c}0.64 \\
(0.96)\end{array}$ & $\begin{array}{c}0.87 \\
(1.45)\end{array}$ \\
\hline Percent Upper Class in Favor of Agreement & $\begin{array}{l}-0.33 \\
(0.35)\end{array}$ & $\begin{array}{l}0.94^{\circ} \\
(0.52)\end{array}$ & $\begin{array}{l}-1.76^{*} \\
(0.77)\end{array}$ \\
\hline Total Contributions in Favor & $\begin{array}{c}0.27 * * * \\
(0.07)\end{array}$ & $\begin{array}{c}0.43 * * \\
(0.14)\end{array}$ & $\begin{array}{c}0.32 * * \\
(0.1)\end{array}$ \\
\hline Total Contributions Against & $\begin{array}{c}-6.38 * * * \\
(0.79)\end{array}$ & $\begin{array}{c}-6.40 * * * \\
(1.19)\end{array}$ & $\begin{array}{c}-7.2 * * * \\
(1.35)\end{array}$ \\
\hline Inequality (Gini Coefficient) & $\begin{array}{l}-18.13 \\
(12.71)\end{array}$ & $\begin{array}{c}0.78 \\
(28.12)\end{array}$ & $\begin{array}{l}-54.62^{\circ} \\
(28.72)\end{array}$ \\
\hline Member of President's Party & $\begin{array}{l}-0.06 \\
(0.31)\end{array}$ & $\begin{array}{c}0.17 \\
(0.48)\end{array}$ & $\begin{array}{l}-0.32 \\
(0.53)\end{array}$ \\
\hline No High School & $\begin{array}{l}3.80 \\
(9.95)\end{array}$ & $\begin{array}{l}-25.45 \\
(17.89)\end{array}$ & $\begin{array}{c}8.81 \\
(15.43)\end{array}$ \\
\hline High School & $\begin{array}{c}-16.49 * * \\
(6.32)\end{array}$ & $\begin{array}{l}-35.6 * * \\
(13.11)\end{array}$ & $\begin{array}{l}-3.24 \\
(9.62)\end{array}$ \\
\hline College & $\begin{array}{l}-3.98 \\
(8.93)\end{array}$ & $\begin{array}{l}-33.79^{*} \\
(13.89)\end{array}$ & $\begin{array}{c}20.55 \\
(18.94)\end{array}$ \\
\hline Mean Income & $\begin{array}{l}-0.21 \\
(0.29)\end{array}$ & $\begin{array}{l}1.11^{*} \\
(0.52)\end{array}$ & $\begin{array}{l}-1.08^{\circ} \\
(0.64)\end{array}$ \\
\hline Exports to Country(ies) in Agreement & $\begin{array}{c}0.02 \\
(0.01)\end{array}$ & $\begin{array}{c}0.01 \\
(0.02)\end{array}$ & $\begin{array}{c}0.01 \\
(0.02)\end{array}$ \\
\hline CAFTA-DR & $\begin{array}{l}-0.50 \\
(4.25)\end{array}$ & $\begin{array}{l}-14.04^{\circ} \\
(8.45)\end{array}$ & $\begin{array}{c}8.98 \\
(6.72)\end{array}$ \\
\hline Peru & $\begin{array}{c}0.48 \\
(3.71)\end{array}$ & $\begin{array}{l}-3.4 \\
(6.78)\end{array}$ & $\begin{array}{c}2.41 \\
(5.29)\end{array}$ \\
\hline Korea & $\begin{array}{l}0.98^{*} \\
(0.47)\end{array}$ & $\begin{array}{l}1.05 \\
(0.82)\end{array}$ & $\begin{array}{l}1.45^{*} \\
(0.67)\end{array}$ \\
\hline Constant & $20.82 *$ & 3.96 & $50.23 * * *$ \\
\hline $\mathrm{N}$ & 400 & 182 & 218 \\
\hline Pseudo R-squared & 0.32 & 0.33 & 0.42 \\
\hline
\end{tabular}

${ }^{57}$ There are issues of collinearity and multicollinearity among the regressors. Appendix 4 has a correlation matrix for all independent and control variables. There is a high degree of correlation between each of the variables measuring percent in favor of an agreement by class, 0.97 or above. When the data are broken into high and low inequality categories there is a similarly high correlation between the variables measuring percent in favor of an agreement by class. Given that similar factors likely influence an individual's support of trade regardless of their class based on the area they live, a high degree of correlation between these categories is not entirely surprising, and point to the need to bring in a control variable for region. There could also be collinearity between inequality and education. If there are a large number of poorly educated people in an area, and a few relatively educated people in that area, there will likely be increased inequality as there will be a high amount of people with a relatively low earning capacity and a few people with the capacity to earn high incomes. Appendix 5 gives the correlation between the independent and control variables and the two measures of inequality. There is moderate to high correlation between the percent of those with no high school diploma and inequality. There is also a moderate level of correlation between contributions in favor and inequality. This is likely a result of business groups seeing an opportunity to influence policy when there is higher inequality and the public is able to have less influence. There is also a significant amount of multicollinearity within the model. When the model is run for all levels of inequality using the Gini index as the measure of inequality VIFs are very high for the variables measuring percent in favor of an agreement by class, $>1,700$ for each of the four variables. The VIF for college and no high school are also high, at 10.06, and 7.11, respectively. There are similarly high VIFs when the model is run for the high and low inequality groups of states, and when Gini ranking is used as the measure of inequality. The collinearity and multicollinearity in the model inflates the standard errors of those hypothesis tests. As a result, the statistical tests presented are likely weaker than they should be and the hypothesis tests understate the importance of some variables. In the future these issues will need to be addressed. 
favor and in the expected negative direction for groups against. Contributions to a senator from groups in favor of the agreement increase the likelihood of the senator voting for an agreement, while contributions to a senator from groups against the agreement decrease the likelihood of a senator voting in favor of an agreement. Table 8 reports the results of the same regression except inequality ranking is used as the measure of inequality, and the high and low categories are broken down into the top half and bottom half of the inequality rankings. Comparing these

Table 8: Results for All States, and High and Low Inequality States Using Gini Coefficient Ranking to Measure Inequality

\begin{tabular}{|c|c|c|c|}
\hline & All & Low Inequality & High Inequality \\
\hline Percent Lower Class in Favor of Agreement & $\begin{array}{l}-0.26 \\
(0.52)\end{array}$ & $\begin{array}{c}0.79 \\
(0.73)\end{array}$ & $\begin{array}{c}-2.38^{*} \\
(1.1)\end{array}$ \\
\hline Percent Lower Middle Class in Favor of & 0.15 & $-2.05^{\circ}$ & $3.07^{\circ}$ \\
\hline Agreement & $(0.81)$ & (1.16) & $(1.72)$ \\
\hline Percent Upper Middle Class in Favor of & 0.40 & 0.38 & 0.84 \\
\hline Agreement & $(0.63)$ & $(0.93)$ & $(1.46)$ \\
\hline Percent Upper Class in Favor of Agreement & -0.32 & $\begin{array}{r}0.92^{\circ} \\
(0.52)\end{array}$ & $\begin{array}{c}-1.68^{*} \\
(078)\end{array}$ \\
\hline Total Contributions in Favor & $\begin{array}{c}0.25^{* * *} \\
(0.07)\end{array}$ & $\begin{array}{c}(0.52) \\
0.51 * * * \\
(0.14)\end{array}$ & $\begin{array}{l}(0 . / 8) \\
0.22 * \\
(0.09)\end{array}$ \\
\hline Total Contributions Against & $\begin{array}{c}-6.38 * * * \\
(0.79)\end{array}$ & $\begin{array}{c}-7.13 * * * \\
(1.19)\end{array}$ & $\begin{array}{c}-6.64 * * * \\
(1.35)\end{array}$ \\
\hline Inequality (Gini Coefficient Ranking) & $\begin{array}{l}-0.02 \\
(0.02)\end{array}$ & $\begin{array}{l}-0.01 \\
(0.04)\end{array}$ & $\begin{array}{l}-0.06 \\
(0.04)\end{array}$ \\
\hline Member of President's Party & $\begin{array}{l}-0.04 \\
(0.31)\end{array}$ & $\begin{array}{c}0.1 \\
(0.48)\end{array}$ & $\begin{array}{l}-0.16 \\
(0.53)\end{array}$ \\
\hline No High School & $\begin{array}{l}0.31 * * \\
(9.89)\end{array}$ & $\begin{array}{l}-18.46 \\
(16.8)\end{array}$ & $\begin{array}{c}-6.96 \\
(16.19)\end{array}$ \\
\hline High School & $\begin{array}{l}-17.23 \\
(6.29)\end{array}$ & $\begin{array}{c}-36.05^{* *} \\
(12.79)\end{array}$ & $\begin{array}{l}-11.15 \\
(9.93)\end{array}$ \\
\hline College & $\begin{array}{l}-6.49 \\
(8.7)\end{array}$ & $\begin{array}{l}-26.13^{*} \\
(12.52)\end{array}$ & $\begin{array}{c}8.63 \\
(19.61)\end{array}$ \\
\hline Mean Income & $\begin{array}{l}-0.17 \\
(0.29)\end{array}$ & $\begin{array}{c}0.98 \\
(0.47)\end{array}$ & $\begin{array}{l}-0.98 \\
(0.69)\end{array}$ \\
\hline Exports to Country(ies) in Agreement & $\begin{array}{c}0.02 \\
(0.01)\end{array}$ & $\begin{array}{l}0.003 \\
(0.02)\end{array}$ & $\begin{array}{c}0.02 \\
(0.02)\end{array}$ \\
\hline CAFTA-DR & $\begin{array}{l}-0.27 \\
(4.24)\end{array}$ & $\begin{array}{l}-12.48 \\
(8.33)\end{array}$ & $\begin{array}{c}9.92 \\
(7.14)\end{array}$ \\
\hline Peru & $\begin{array}{l}0.65 \\
(3.7)\end{array}$ & $\begin{array}{l}-2.55 \\
(6.57)\end{array}$ & $\begin{array}{l}3.85 \\
(5.84)\end{array}$ \\
\hline Korea & $\begin{array}{l}0.97^{*} \\
(0.47)\end{array}$ & $\begin{array}{l}1.09 \\
(0.77)\end{array}$ & $\begin{array}{l}1.41^{*} \\
(0.69)\end{array}$ \\
\hline Constant & $13.95^{\circ}$ & 2.87 & $31.53^{*}$ \\
\hline $\mathrm{N}$ & 400 & 200 & 200 \\
\hline Pseudo R-squared & 0.32 & 0.36 & 0.39 \\
\hline
\end{tabular}


results to those in Table 7, the results are very similar, in both the variables are significant and the direction of the coefficients are the same. For the high and low inequality groups of states, both contributions from interest groups against the agreements, and contributions from interest groups in favor of the agreements, are significant and in the expected direction. Contributions in favor make a senator more likely to vote for an agreement, and contributions against make a senator less likely to vote for an agreement, which was expected.

Tables 7 and 8 also have similar results in terms of the impact of the public's opinion on how senators' vote. For the group of states with higher levels of inequality, the coefficients are significant and in the negative direction for the percentage of the lower class in favor of the agreement and the percentage of the upper class in favor of the agreement. These results show that when there is high inequality senators are not responding to public opinion from the high and low groups, rather senators vote against their opinion. The expectation is public opinion from those in the low category will have little influence when there is high inequality, therefore the results for the low category are in line with expectations. However, the results for the upper class group are the opposite from what was expected, the upper class group was expected to have a significant positive influence when inequality is high. Additionally, in both tables, for the high inequality group of states the percentage of the lower middle class in favor of an agreement is significant at the $\mathrm{p}<0.1$ level and the sign is in the positive direction. This contradicts expectations given that those in the lower class groups are not expected to have much influence when there is high inequality. While the percentage of the lower middle class in favor is only significant at the $\mathrm{p}<0.1$ level, this does give some evidence that when there is high inequality this group has greater influence. In both tables, the sign of the coefficient for the percentage of the upper middle class that is in favor is positive, however the coefficient is not significant. 
Those in the upper middle class were expected to have little influence when there is high inequality, therefore these results are in line with expectations.

Looking across both tables at the results for the low inequality group of states, the coefficient for the percentage of the upper class that is in favor is significant at the $p<0.1$ level and the sign is in the positive direction. This is what was expected given that the upper class group was expected to have influence at all levels of inequality, however, there needs to be some skepticism of these results given they are only significant at the $\mathrm{p}<0.1$ level. When looking at the negative sign for the percentage of the upper class that is in favor for the high inequality group or states, this gives limited evidence that those in the upper class may have greater influence when there is low inequality than when there is high inequality.

Still examining the low inequality category, for the lower class group the sign is in the expected positive direction, the lower class group was expected to have influence when inequality is low. However, the coefficient for the lower class in favor is not significant, showing their opinion likely has little impact on how senators vote when there is low inequality. As with the high inequality group of states, the coefficient for the upper middle class in favor is in the positive direction, but not sufficient. This gives some limited evidence that the upper middle class may have influence when inequality is both high and low, however more investigation is needed in order to determine if this is the case. For the percentage of the lower middle class that is in favor, the coefficient for the low inequality group is significant at the $\mathrm{p}<$ 0.05 level in Table 7, and significant at the $\mathrm{p}<0.1$ level in Table 8 , and in both tables the sign is negative. When this is compared to the results for the high inequality group, this is pointing to the lower middle class group having a negative influence when there is low inequality and a positive influence when there is high inequality, exactly the opposite from what was expected. 
When the model is run with all states, none of the public opinion variables are as significant as when the model is run using Gini or inequality ranking. All coefficients for the class preferences were expected to be in the positive direction, in the results only the lower middle class and upper middle class categories are in the positive direction, providing limited evidence that the middle class groups might have the greatest impact over trade policy votes. This may mean senators are more concerned about going against the middle class than siding with the upper class, and this particularly may be the case because the middle class has more numbers and is relatively likely to vote and to participate in other ways. There is likely little effect from the preferences of the lower class because of the lower likelihood of this group voting and participating in other ways, and the upper class might not have influence because of their relatively low numbers. However, more investigation is needed to determine if this is the case.

As a check of these results, I include an additional control variable for the percentage of agreements a senator voted in favor of in the past, this controls for whether or not a senator is more or less in favor of free trade in general. This variable is constructed by dividing the number of agreements a senator voted yes on previously by the number of agreements a senator had an opportunity to vote on, then multiplying this ratio by 100 . The Library of Congress keeps records of votes in the Senate on trade agreements. Senators who have served for a relatively short period of time have not had the opportunity to vote on any trade agreements, therefore creating the issue of missing data. Senators who voted in favor of trade agreements in the past are expected to vote in favor of them in the future because they are likely to face similar pressures when voting on new agreements. There is the issue that many Senators were not in office long enough to have a chance to vote on previous agreements, therefore these cases were 
dropped. This means when this additional control is included, the $\mathrm{N}$ is reduced from 400 to 296

when all agreements are examined; results are in Appendix 6. Not surprisingly, votes on prior

Table 9: Predicted Probabilities, The Effect of Contributions in Favor, Contributions Against, and Percent in Favor by Income Category Using Gini Coefficient ${ }^{58}$

\begin{tabular}{|c|c|c|c|c|c|c|c|c|c|}
\hline & \multicolumn{3}{|c|}{$C A F T A-D R$} & \multicolumn{3}{|c|}{ Peru } & \multicolumn{3}{|c|}{ Korea } \\
\hline & All & $\begin{array}{c}\text { Low } \\
\text { Inequality }\end{array}$ & $\begin{array}{c}\text { High } \\
\text { Inequality }\end{array}$ & All & $\begin{array}{c}\text { Low } \\
\text { Inequality }\end{array}$ & $\begin{array}{c}\text { High } \\
\text { Inequality }\end{array}$ & All & $\begin{array}{c}\text { Low } \\
\text { Inequality }\end{array}$ & $\begin{array}{c}\text { High } \\
\text { Inequality }\end{array}$ \\
\hline \multicolumn{10}{|c|}{ Contributions in Favor } \\
\hline-0.25 std. dev. & 0.68 & 0.85 & 0.62 & 0.73 & 0.99 & 0.25 & 0.76 & 1.00 & 0.22 \\
\hline-0.1 std. dev. & 0.71 & 0.86 & 0.65 & 0.75 & 0.99 & 0.28 & 0.78 & 1.00 & 0.25 \\
\hline base & 0.72 & 0.87 & 0.67 & 0.77 & 0.99 & 0.30 & 0.79 & 1.00 & 0.26 \\
\hline +0.1 std. dev. & 0.74 & 0.88 & 0.69 & 0.78 & 0.99 & 0.32 & 0.80 & 1.00 & 0.28 \\
\hline \multicolumn{10}{|c|}{ Contributions Against } \\
\hline-0.25 std. dev. & 0.79 & 0.91 & 0.76 & 0.83 & 0.99 & 0.39 & 0.84 & 1.00 & 0.35 \\
\hline-0.1 std. dev. & 0.75 & 0.89 & 0.71 & 0.79 & 0.99 & 0.33 & 0.81 & 1.00 & 0.30 \\
\hline base & 0.72 & 0.87 & 0.67 & 0.77 & 0.99 & 0.30 & 0.79 & 1.00 & 0.26 \\
\hline+0.1 std. dev. & 0.69 & 0.85 & 0.64 & 0.74 & 0.99 & 0.27 & 0.76 & 1.00 & 0.23 \\
\hline+0.25 std. dev. & 0.64 & 0.82 & 0.58 & 0.70 & 0.99 & 0.22 & 0.72 & 1.00 & 0.19 \\
\hline \multicolumn{10}{|c|}{ Lower Class in Favor } \\
\hline-0.25 std. dev. & 0.92 & 0.07 & 1.00 & 0.94 & 0.54 & 1.00 & 0.94 & 0.79 & 1.00 \\
\hline base & 0.72 & 0.87 & 0.67 & 0.77 & 0.99 & 0.30 & 0.79 & 1.00 & 0.26 \\
\hline+0.1 std. dev. & 0.59 & 0.98 & 0.01 & 0.64 & 1.00 & 0.00 & 0.67 & 1.00 & 0.00 \\
\hline+0.25 std. dev. & 0.37 & 1.00 & 0.00 & 0.42 & 1.00 & 0.00 & 0.46 & 1.00 & 0.00 \\
\hline \multicolumn{10}{|c|}{ Lower Middle Class in Favor } \\
\hline-0.25 std. dev. & 0.51 & 1.00 & 0.00 & 0.57 & 1.00 & 0.00 & 0.60 & 1.00 & 0.00 \\
\hline-0.1 std. dev. & 0.64 & 1.00 & 0.00 & 0.70 & 1.00 & 0.00 & 0.72 & 1.00 & 0.00 \\
\hline base & 0.72 & 0.87 & 0.67 & 0.77 & 0.99 & 0.30 & 0.79 & 1.00 & 0.26 \\
\hline+0.1 std. dev. & 0.79 & 0.05 & 1.00 & 0.83 & 0.44 & 1.00 & 0.84 & 0.72 & 0.99 \\
\hline+0.25 std. dev. & 0.87 & 0.00 & 1.00 & 0.89 & 0.00 & 1.00 & 0.90 & 0.00 & 1.00 \\
\hline \multicolumn{10}{|c|}{ Upper Middle Class in Favor } \\
\hline-0.25 std. dev. & 0.29 & 0.25 & 0.04 & 0.34 & 0.84 & 0.01 & 0.37 & 0.94 & 0.01 \\
\hline-0.1 std. dev. & 0.55 & 0.67 & 0.29 & 0.61 & 0.97 & 0.08 & 0.64 & 0.99 & 0.07 \\
\hline base & 0.72 & 0.87 & 0.67 & 0.77 & 0.99 & 0.30 & 0.79 & 1.00 & 0.26 \\
\hline+0.1 std. dev. & 0.84 & 0.96 & 0.91 & 0.87 & 1.00 & 0.68 & 0.89 & 1.00 & 0.64 \\
\hline+0.25 std. dev. & 0.94 & 0.99 & 0.99 & 0.95 & 1.00 & 0.96 & 0.96 & 1.00 & 0.95 \\
\hline \multicolumn{10}{|c|}{ Upper Class in Favor } \\
\hline base & 0.72 & 0.87 & 0.67 & 0.77 & 0.99 & 0.30 & 0.79 & 1.00 & 0.26 \\
\hline+0.1 std. dev. & 0.60 & 0.97 & 0.11 & 0.66 & 1.00 & 0.03 & 0.69 & 1.00 & 0.02 \\
\hline+0.25 std. dev. & 0.41 & 1.00 & 0.00 & 0.47 & 1.00 & 0.00 & 0.50 & 1.00 & 0.00 \\
\hline
\end{tabular}

Holding all variables at their mean or mode (mode is only used for member of the President's party), adjusting variable in question . For the CAFTA-DR, Peru, and Korea categories, the mean was used if predicted probabilities were being modeled for the agreement, while the other two agreements were held at zero. The Colombia agreement is excluded because Colombia was used as the base category in the models.

${ }^{58}$ Moving from -0.25 std. dev. to +0.25 std. dev. for each of the trade agreements, the variables measuring percent in favor of an agreement by class, across the low and high inequality groups, there is a large change in the probability of a senator voting for an agreement, sometimes from 0 to 1 or 1 to 0 . The coefficients for the four variables measuring percent of those in favor of an agreement are relatively larger when the model is run with the low and high inequality group of states than when it is run for all states. Because there is a large degree of correlation between each of these four variables it is likely that a change in one of these variables is also capturing the effect of the other variables measuring support for the agreement. Again, multicollinearity weakens the significance tests and likely means the effects of public support for an agreement on a senator voting for that agreement may well be stronger than reported. 
agreements are highly significant at the $\mathrm{p}<0.001$ level across both models and all inequality groups. This is expected given the conditions in a Senator's state, such as pressure to adopt certain trade preferences, are not expected to change rapidly. When comparing these results to the previous results, the most notable difference is total contributions in favor are no longer significant for either of the models across inequality groups. However, it could be the case that the influence from these contributions are captured in votes on prior agreements as contributions in the past also likely influenced how senators voted on trade agreements. Thus, this additional control variable does not significantly improve the model.

The two models were also run for each of the individual agreements, instead of running a panel regression with controls for each of the agreements. Summary statistics for each of the agreements are in Appendix 7 and regression results are in Appendix 8. Although the independent variables were much less likely to be significant, likely because of the lower $\mathrm{N}$, the results for when the regressions were run for the separate agreements were not significantly different than when they were run for all agreements in terms of directions of the signs.

Tables 9 and 10 give the predicted probabilities of a senator voting in favor of an agreement when adjusting for contributions in favor, contributions against, lower class in favor, lower middle class in favor, upper middle class in favor, and upper class in favor. Table 9 uses the results of the regressions using the Gini coefficient as the measure of inequality and Table 10 using inequality ranking as the measure of inequality. As with the above tables, these two tables show similar results. For the income categories the expectation is that, when moving from low to high income inequality group of states, lower class, lower middle class, and upper middle class influence will decline, while the influence of the upper class will increase. 
Table 10: Predicted Probabilities, The Effect of Contributions in Favor, Contributions Against, and Percent in Favor by Income Category Using Gini Coefficient Ranking ${ }^{59}$

\begin{tabular}{|c|c|c|c|c|c|c|c|c|c|}
\hline & \multicolumn{3}{|c|}{ CAFTA-DR } & \multicolumn{3}{|c|}{ Peru } & \multicolumn{3}{|c|}{ Korea } \\
\hline & All & $\begin{array}{c}\text { Low } \\
\text { Inequality }\end{array}$ & $\begin{array}{c}\text { High } \\
\text { Inequality } \\
\end{array}$ & All & $\begin{array}{c}\text { Low } \\
\text { Inequality }\end{array}$ & $\begin{array}{c}\text { High } \\
\text { Inequality }\end{array}$ & All & $\begin{array}{c}\text { Low } \\
\text { Inequality }\end{array}$ & $\begin{array}{c}\text { High } \\
\text { Inequality } \\
\end{array}$ \\
\hline \multicolumn{10}{|c|}{ Contributions in Favor } \\
\hline-0.1 std. dev. & 0.70 & 0.82 & 0.57 & 0.74 & 0.98 & 0.22 & 0.76 & 0.99 & 0.14 \\
\hline base & 0.71 & 0.83 & 0.59 & 0.76 & 0.98 & 0.24 & 0.77 & 0.99 & 0.14 \\
\hline+0.1 std. dev. & 0.73 & 0.85 & 0.60 & 0.77 & 0.99 & 0.25 & 0.78 & 0.99 & 0.15 \\
\hline+0.25 std. dev. & 0.74 & 0.87 & 0.62 & 0.79 & 0.99 & 0.27 & 0.80 & 0.99 & 0.17 \\
\hline \multicolumn{10}{|c|}{ Contributions Against } \\
\hline-0.25 std. dev. & 0.78 & 0.88 & 0.67 & 0.82 & 0.99 & 0.31 & 0.83 & 1.00 & 0.19 \\
\hline-0.1 std. dev. & 0.74 & 0.86 & 0.62 & 0.78 & 0.99 & 0.26 & 0.80 & 0.99 & 0.16 \\
\hline base & 0.71 & 0.83 & 0.59 & 0.76 & 0.98 & 0.24 & 0.77 & 0.99 & 0.14 \\
\hline +0.1 std. dev. & 0.68 & 0.81 & 0.55 & 0.73 & 0.98 & 0.21 & 0.74 & 0.99 & 0.13 \\
\hline+0.25 std. dev. & 0.63 & 0.77 & 0.50 & 0.68 & 0.97 & 0.18 & 0.70 & 0.99 & 0.11 \\
\hline \multicolumn{10}{|c|}{ Lower Class in Favor } \\
\hline-0.25 std. dev. & 0.90 & 0.08 & 1.00 & 0.92 & 0.50 & 1.00 & 0.93 & 0.72 & 1.00 \\
\hline base & 0.71 & 0.83 & 0.59 & 0.76 & 0.98 & 0.24 & 0.77 & 0.99 & 0.14 \\
\hline+0.1 std. dev. & 0.59 & 0.96 & 0.01 & 0.64 & 1.00 & 0.00 & 0.66 & 1.00 & 0.00 \\
\hline+0.25 std. dev. & 0.39 & 1.00 & 0.00 & 0.45 & 1.00 & 0.00 & 0.47 & 1.00 & 0.00 \\
\hline \multicolumn{10}{|c|}{ Lower Middle Class in Favor } \\
\hline-0.25 std. dev. & 0.54 & 1.00 & 0.00 & 0.60 & 1.00 & 0.00 & 0.62 & 1.00 & 0.00 \\
\hline-0.1 std. dev. & 0.65 & 1.00 & 0.00 & 0.70 & 1.00 & 0.00 & 0.72 & 1.00 & 0.00 \\
\hline base & 0.71 & 0.83 & 0.59 & 0.76 & 0.98 & 0.24 & 0.77 & 0.99 & 0.14 \\
\hline+0.1 std. dev. & 0.77 & 0.07 & 1.00 & 0.81 & 0.48 & 0.99 & 0.82 & 0.70 & 0.99 \\
\hline+0.25 std. dev. & 0.84 & 0.00 & 1.00 & 0.87 & 0.00 & 1.00 & 0.88 & 0.00 & 1.00 \\
\hline \multicolumn{10}{|c|}{ Upper Middle Class in Favor } \\
\hline-0.25 std. dev. & 0.28 & 0.45 & 0.03 & 0.32 & 0.91 & 0.01 & 0.34 & 0.96 & 0.00 \\
\hline-0.1 std. dev. & 0.54 & 0.71 & 0.23 & 0.60 & 0.97 & 0.06 & 0.62 & 0.99 & 0.03 \\
\hline base & 0.71 & 0.83 & 0.59 & 0.76 & 0.98 & 0.24 & 0.77 & 0.99 & 0.14 \\
\hline+0.1 std. dev. & 0.84 & 0.91 & 0.87 & 0.87 & 0.99 & 0.60 & 0.88 & 1.00 & 0.44 \\
\hline+0.25 std. dev. & 0.94 & 0.97 & 0.99 & 0.95 & 1.00 & 0.94 & 0.96 & 1.00 & 0.89 \\
\hline \multicolumn{10}{|c|}{ Upper Class in Favor } \\
\hline base & 0.71 & 0.83 & 0.59 & 0.76 & 0.98 & 0.24 & 0.77 & 0.99 & 0.14 \\
\hline+0.1 std. dev. & 0.59 & 0.96 & 0.09 & 0.65 & 1.00 & 0.02 & 0.67 & 1.00 & 0.01 \\
\hline+0.25 std. dev. & 0.40 & 1.00 & 0.00 & 0.46 & 1.00 & 0.00 & 0.48 & 1.00 & 0.00 \\
\hline
\end{tabular}

Holding all variables at their mean or mode (mode is only used for member of the President's party), adjusting variable in question. For the CAFTA-DR, Peru, and Korea categories, the mean was used if predicted probabilities were being modeled for the agreement, while the other two agreements were held at zero. The Colombia agreement is excluded because Colombia was used as the base category in the models.

The first hypothesis, the higher the economic inequality in a state, the more the trade preferences of a senator from that state will reflect the trade preferences of high-income individuals, is not supported. In both tables, across all trade agreements when moving from -0.25 std. dev. to +0.25 std. dev. for the low inequality group of states the influence of the upper class on a senator's vote increases, while the opposite is the case for the high inequality group. Furthermore, looking at the baseline category, comparing the low and high inequality groups, the

\footnotetext{
${ }^{59}$ Appendix 9 reports predicted probabilities for individual agreements.
} 
upper class has more influence when inequality is higher. This is the opposite of what was expected in the first hypothesis.

The second hypothesis, the higher the economic inequality in a state, the less the trade preferences of a senator from that state will reflect the trade preferences of middle and lower income individuals, is partially supported. In both tables across all trade agreements when moving from -0.25 std. dev. to +0.25 std. dev. for the low inequality group of states the influence of the lower class on a senator's vote increase, while the opposite is the case for the high inequality group. That the lower class' influence decreases for the high inequality group of states provides support for the second hypothesis. For the lower middle class in favor the results are the opposite of those for the lower class in favor. In both tables across all trade agreements when moving from -0.25 std. dev. to $+0.25 \mathrm{std}$. dev. for the low inequality group of states, the influence of the lower middle class on a senator's likelihood of voting in favor of an agreement decreases, while the opposite is the case for the high inequality group. These results provide evidence against the second hypothesis, the lower middle class seems to have greater influence when there is higher inequality. Looking at the upper middle class in favor in both the high and low inequality group of states in both categories moving from -0.25 std. dev. to $+0.25 \mathrm{std}$. dev. increases a senator's likelihood of voting in favor of an agreement. Again, not providing support for the second hypothesis.

Moving on to examining the effect of interest group contributions. The third hypothesis states, the greater the economic inequality in a state, the more the trade preferences of a senator from that state will reflect the trade preferences of business and industry interest groups. While the fourth hypothesis predicted the greater the economic inequality in a state, the less the trade preferences of a senator from that state will reflect the trade preferences of labor groups. For 
these hypotheses to be supported the probability of a senator voting in favor of an agreement should be higher when there is high inequality and they receive contributions from groups in favor of the agreement, while the reverse should be the case when they receive interest group contributions for groups against the agreement. For contributions in favor moving from the low inequality group to the high inequality group influence decreases. Across the trade agreements in both tables in both the high and low categories moving from $-0.25 \mathrm{std}$. dev. to $+0.25 \mathrm{std}$. dev. increases the likelihood of a senator voting in favor of an agreement, or has no effect. Neither of these results support the third hypothesis. However, the results for contributions against do support the fourth hypothesis, moving from the low inequality category to the high inequality category contributions against decrease the likelihood of a senator voting in favor of an agreement.

\section{Discussion and Conclusion}

Given the results for trade preferences by class variables are not significant when the two models are run for all states, but some are significant when the models are run with the low inequality group of states and the high inequality group of states, shows the influence of the public does likely vary with inequality, but not in the way I originally expected. The results for interest groups in favor were far from expected, it may be the case that when there is higher inequality the public becomes more sensitive to changes in inequality and therefore senators become more cautious when it comes to favoring policies that may increase inequality, such as

trade agreements. This would be supported by contributions against these agreements having a greater impact when there is higher inequality. Also surprising are the results for the influence of the public, specifically the results that the upper class have more influence under low 
inequality than high inequality and that the lower middle class has greater influence under high inequality than low inequality.

It may be the case that the middle class pays little attention to trade when there is low inequality because they are not as concerned with the effects of trade on inequality. Guisinger (2009), finds trade is a low saliency issue among voters, giving Senators less incentive to listen to voters on trade, this poses a potential problem for determining the impact of voter preferences on trade policy. However, if a politician or party strays too far away from voters' preferences then opposition candidates have an incentive to focus on how the incumbents are ignoring the preferences of their constituents. This in turn gives the incumbents an incentive to abide by the trade preferences of their constituents, because even if trade is not a major issue one election, it could become a major issue and a come back to haunt politicians. ${ }^{60}$ This in turn allows politicians to adopt the preferences of the upper class who are likely more engaged. Then when there is high inequality the middle class, particularly the lower middle class, those who are likely to have manufacturing jobs that will be directly affected by trade, become more concerned with trade and therefore voices their opinion on trade to politicians.

If the lower middle class were more concerned with job losses from trade the sign would be negative and not positive. Therefore, the lower middle class may see trade more as an opportunity than a negative when there is high inequality. Thus, when there is high inequality politicians listen more to the middle class as they are more engaged on trade. This means, moving from low inequality to high inequality, the salience of trade policy to the lower middle class is likely increasing. It could also be the case that politicians are driving the saliency of trade policy among the public. In the 2016 presidential campaign both major party candidates

\footnotetext{
${ }^{60}$ For example, Donald Trump made trade a central issue of his campaign, criticizing previous administrations for what he called "stupid" trade deals.
} 
made opposition to the Trans-Pacific Partnership and a broader discussion of what they call unfair trade practices a major part of their campaign. While this is coming at a time when there is concern among the public about high-inequality and the loss of manufacturing jobs from trade, the candidates focusing on trade has likely made it more salient among the electorate. Ideally a measure of salience would be included in the future to account for changing public priority on these agreements.

At issue could also be reverse causality, politicians adopting the preferences of interest groups and then selling these preferences to the public, rather than adopting the preferences of the public. This could be the case given the strong influence of interest groups at all levels of inequality. Politicians want to maintain a beneficial relationship with interest groups and therefore when it comes to trade deals they try and convince the public to adopt the preferences of interest groups. However, this might not be the case given that the third hypothesis, the greater the economic inequality in a state, the more the trade preferences of a senator from that state will reflect the trade preferences of business and industry interest groups, was not supported. The public may keep a closer eye on what their elected officials are doing when there are higher levels of inequality for fear that rising inequality may cause their relative incomes to shrink.

Overall what the results point to is trade policy preferences formation and trade policy influence is likely much more complicated than originally expected. Understanding how individuals form their opinions about trade, how these opinions change with inequality, and how the saliency of trade policy to the public changes with inequality is a complex task. Therefore, in the next chapter, in addition to including state level analysis to determine how the public effects 
policy as inequality changes, I also look at how individuals participate at different levels of inequality. 


\section{Appendix 1: MRP Matching Variables}

MRP Matching Variables Gender (2006, 2008, \&2012)

\begin{tabular}{ll}
\hline ACS & CCES \\
\hline Female & Female \\
Male & Male \\
\hline
\end{tabular}

MRP Matching Variables Education (2006, 2008, \&2012)

\begin{tabular}{ll}
\hline ACS & CCES \\
\hline No schooling completed & Did not graduate from high school \\
Nursery school to grade 4 & \\
Grade 5 or 6 & \\
Grade 7 or 8 & \\
Grade 9 & \\
Grade 10 & \\
Grade 11 & High school graduate \\
12 th grade, no diploma & Some college, but no degree (yet) \\
High school graduate or GED & \\
Some college, but less than 1 year & 2-year college degree \\
1 or more years of college credit, no diploma & 4-year college degree \\
Associate's degree, type not specified & Postgraduate degree (MA, MBA, MD, JD, PhD, etc.) \\
Bachelor's degree & \\
Master's degree & \\
Professional degree beyond a bachelor's & \\
Doctoral degree &
\end{tabular}


MRP Matching Variables Family Income $(2006,2008, \&$ 2012)

\begin{tabular}{|c|c|c|}
\hline & ACS & CCES \\
\hline Family & \multirow{14}{*}{ Continuous income measure used in ACS } & (1) less than $\$ 10,000$ \\
\hline Income & & (2) $\$ 10,000-\$ 14,999$ \\
\hline$(2006 \&$ & & (3) $\$ 15,000-\$ 19,999$ \\
\hline \multirow{11}{*}{ 2008) } & & (4) $\$ 20,000-\$ 24,999$ \\
\hline & & (5) $\$ 25,000-\$ 29,999$ \\
\hline & & (6) $\$ 30,000-\$ 39,999$ \\
\hline & & (7) $\$ 40,000-\$ 49,999$ \\
\hline & & (8) $\$ 50,000-\$ 59,999$ \\
\hline & & (9) $\$ 60,000-\$ 69,999$ \\
\hline & & (10) $\$ 70,000-\$ 79,999$ \\
\hline & & (11) $\$ 80,000-\$ 99,999$ \\
\hline & & (12) $\$ 100,000-\$ 119,999$ \\
\hline & & (13) $\$ 120,000-\$ 149,999$ \\
\hline & & (14) $\$ 150,000$ or more \\
\hline Family & \multirow[t]{15}{*}{ Continuous income measure used in ACS } & (1) less than $\$ 10,000$ \\
\hline Income & & (2) $\$ 10,000-\$ 19,999$ \\
\hline (2012) & & (3) $\$ 20,000-\$ 29,999$ \\
\hline & & (4) $\$ 30,000-\$ 39,999$ \\
\hline & & (5) $\$ 40,000-\$ 49,999$ \\
\hline & & (6) $\$ 50,000-\$ 59,999$ \\
\hline & & (7) $\$ 60,000-\$ 69,999$ \\
\hline & & (8) $\$ 70,000-\$ 79,999$ \\
\hline & & (9) $\$ 80,000-\$ 99,999$ \\
\hline & & (10) $\$ 100,000-\$ 119,999$ \\
\hline & & (11) $\$ 120,000-\$ 149,999$ \\
\hline & & (12) $\$ 150,000-\$ 199,999$ \\
\hline & & (13) $\$ 200,000-\$ 249,999$ \\
\hline & & (14) $\$ 250,000-\$ 349,999$ \\
\hline & & (15) $\$ 350,000-\$ 499,999$ \\
\hline
\end{tabular}

MRP Matching Variables Age Categories (2006, 2008, \&2012)

Continuous variables used for age in both ACS and CCES, broken down into age categories
$18-24$
25-29
30-34
$35-39$
$40-44$
$45-49$
$50-54$
$55-59$
60-64
65-69
$70-74$
75-79
80-84
85-89
90 and up 


\begin{tabular}{|c|c|}
\hline Category & Types of Interest Groups Included in Category \\
\hline Agribusiness & $\begin{array}{l}\text { Crop Production \& Basic Processing (Vegetables \& Fruits, Sugar Cane \& Sugar Beets), Tobacco, } \\
\text { Dairy, Poultry \& Eggs, Livestock, Agricultural Services \& Products (Farm Bureaus), Food } \\
\text { Processing \& Sales (Food Products Manufacturing, Food Stores, Meat \& Forest Products), and } \\
\text { Forestry \& Forest Products }\end{array}$ \\
\hline $\begin{array}{l}\text { Communicatio } \\
\text { ns/Electronics }\end{array}$ & $\begin{array}{l}\text { Printing \& Publishing (Books, Magazines \& Newspapers), TV/Movies/Music (Cable \& Satellite } \\
\text { TV Production \& Distribution, Commercial TV \& Radio Stations, Motion Picture Production \& } \\
\text { Distribution, Recorded Music \& Music Production, TV Production), Telephone Utilities, Telecom } \\
\text { Services \& Equipment, Electronics Manufacturing \& Equipment (Computer Software), and } \\
\text { Internet }\end{array}$ \\
\hline Construction & $\begin{array}{l}\text { General Contractors, Home Builders, Special Trade Contractors, Construction Services } \\
\text { (Architectural Services), and Building Materials \& Equipment }\end{array}$ \\
\hline Defense & Defense Aerospace, Defense Electronics, and Miscellaneous Defense \\
\hline Energy \& & Oil \& Gas (Natural Gas Pipelines), Mining (Coal Mining), Alternative Energy Production \& \\
\hline $\begin{array}{l}\text { Natural } \\
\text { Resources }\end{array}$ & Services, Electric Utilities, and Waste Management \\
\hline $\begin{array}{l}\text { Finance, } \\
\text { Insurance \& }\end{array}$ & $\begin{array}{l}\text { Commercial Banks, Savings \& Loans, Credit Union, Finance/Credit Companies (Student Loan } \\
\text { Companies, Payday Lenders), Securities \& Investment (Venture Capital, Hedge Funds, Private }\end{array}$ \\
\hline Real Estate & $\begin{array}{l}\text { Equity \& Investment Firms), Insurance, Real Estate (Mortgage Bankers \& Brokers), Accountants, } \\
\text { and Misc. Finance }\end{array}$ \\
\hline Health & $\begin{array}{l}\text { Health Professionals (Chiropractors, Dentists, \& Nurses), Hospitals \& Nursing Homes, Health } \\
\text { Services/HMOs, and Pharmaceuticals/Health Products (Medical Supplies, Nutritional \& Dietary } \\
\text { Supplements, \& Pharmaceutical Manufacturing) }\end{array}$ \\
\hline $\begin{array}{l}\text { Ideological/ } \\
\text { Single Issue }\end{array}$ & $\begin{array}{l}\text { Republican/Conservative, Democratic/Liberal, Leadership PACs (Democratic Leadership PACs, } \\
\text { Republican Leadership PACs), Foreign \& Defense Policy, Pro-Israel, Women's Issues, Human } \\
\text { Rights (Gay \& Lesbian Rights \& Issues), Environment, Gun Control, Gun Rights, Abortion } \\
\text { Policy/Anti-Abortion, Abortion Policy/Pro-Abortion Rights, and Candidate Committees } \\
\text { (Republican Candidate Committees and Democratic Candidate Committees) }\end{array}$ \\
\hline Labor & $\begin{array}{l}\text { Building Trade Unions, Industrial Unions, Transportation Unions (Air Transport Unions), Public } \\
\text { Sector Unions (Postal Unions \& Teachers Unions), and Misc. Unions }\end{array}$ \\
\hline $\begin{array}{l}\text { Lawyers \& } \\
\text { Lobbyists }\end{array}$ & Lawyers/Law Firms and Lobbyists \\
\hline Misc. Business & $\begin{array}{l}\text { Business Associations, Food \& Beverage (Restaurants \& Drinking Establishments), Beer, Wine \& } \\
\text { Liquor, Retail Sales, Miscellaneous Services (Funeral Services), Business Services } \\
\text { (Advertising/Public Relations), Recreation/Live Entertainment (Professional Sports, Sports } \\
\text { Arenas \& Related Equipment \& Services), Casinos/Gambling (Indian Gambling), } \\
\text { Lodging/Tourism, Chemical \& Related Manufacturing, Steel Production, Misc. Manufacturing \& } \\
\text { Distributing (Clothing Manufacturing), and Textiles }\end{array}$ \\
\hline Other & $\begin{array}{l}\text { Non-profits, Foundations \& Philanthropists, Civil Servants/Public Officials, Education (For-profit } \\
\text { Education), Clergy \& Religious Organizations, and Retired }\end{array}$ \\
\hline Transportation & $\begin{array}{l}\text { Air Transport (Airlines), Automotive (Auto Manufacturers, Car Dealers, Car Dealers, \& Imports), } \\
\text { Trucking, Railroads, and Sea Transport (Cruise Ships \& Lines) }\end{array}$ \\
\hline
\end{tabular}


Appendix 3: Trade Agreements Areas of Coverage

\begin{tabular}{|c|c|c|c|}
\hline CAFTA-DR & $\begin{array}{l}\text { US-Peru Trade } \\
\text { Promotion Agreement }\end{array}$ & $\begin{array}{l}\text { US-Colombia Trade } \\
\text { Promotion Agreement }\end{array}$ & $\begin{array}{l}\text { US-Korea Free Trade } \\
\text { Agreement }\end{array}$ \\
\hline $\begin{array}{l}\text { - Agriculture } \\
\text { - Investment } \\
\text { - Financial Services } \\
\text { - Telecommunications } \\
\text { - Electronic Commerce } \\
\text { - Intellectual Property } \\
\text { Rights } \\
\text { - Labor } \\
\text { - Environment }\end{array}$ & $\begin{array}{l}\text { - Agriculture } \\
\text { - Textiles and Apparel } \\
\text { - Services } \\
\text { - Investment } \\
\text { - Financial Services } \\
\text { - Telecommunications } \\
\text { - Electronic Commerce } \\
\text { - Intellectual Property } \\
\text { Right } \\
\text { - Labor } \\
\text { - Environment }\end{array}$ & $\begin{array}{l}\text { - Agriculture } \\
\text { - Textiles and Apparel } \\
\text { - Services } \\
\text { - Investment } \\
\text { - Financial Services } \\
\text { - Telecommunications } \\
\text { - Electronic Commerce } \\
\text { - Intellectual Property } \\
\text { Rights } \\
\text { - Labor } \\
\text { - Environment }\end{array}$ & $\begin{array}{l}\text { - Agriculture } \\
\text { - Textiles and Apparel } \\
\text { - Pharmaceuticals and } \\
\text { Medical Devices } \\
\text { - Investment } \\
\text { - Services } \\
\text { - Financial Services } \\
\text { - Telecommunications } \\
\text { - Electronic Commerce } \\
\text { - Intellectual Property } \\
\text { Rights } \\
\text { - Labor } \\
\text { - Environment }\end{array}$ \\
\hline
\end{tabular}




\section{Appendix 4: Correlation Matrix for All Independent and Control Variables}

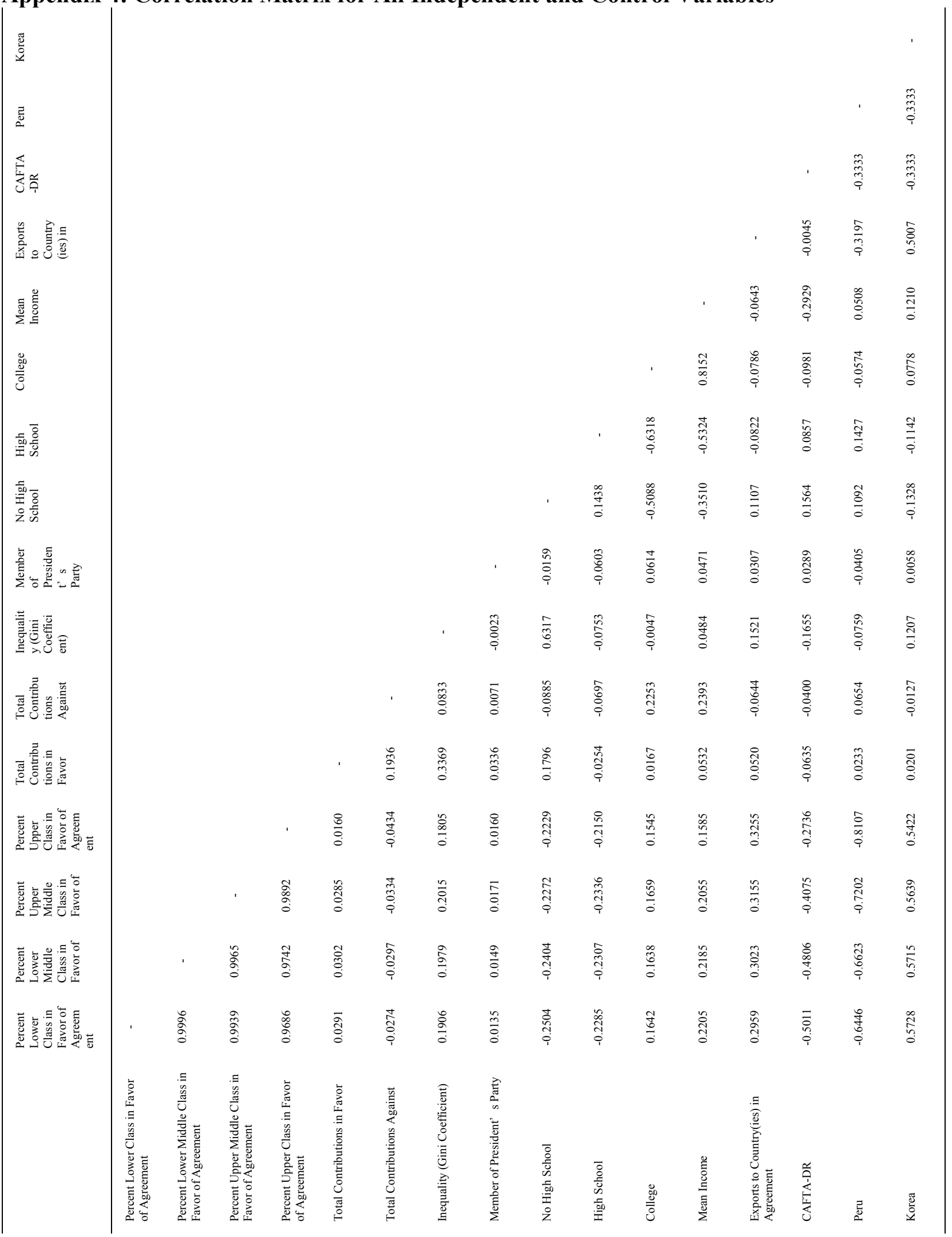




\section{Appendix 5: Correlation between Inequality and Independent and Control Variables}

\begin{tabular}{|c|c|c|c|c|c|c|}
\hline & \multicolumn{3}{|c|}{ Inequality (Gini Coefficient) } & \multicolumn{3}{|c|}{ Inequality (Gini Coefficient Ranking) } \\
\hline & All & $\begin{array}{c}\text { Low } \\
\text { Inequality }\end{array}$ & $\begin{array}{c}\text { High } \\
\text { Inequality }\end{array}$ & All & $\begin{array}{c}\text { Low } \\
\text { Inequality }\end{array}$ & $\begin{array}{c}\text { High } \\
\text { Inequality }\end{array}$ \\
\hline $\begin{array}{l}\text { Percent Lower Class in } \\
\text { Favor of Agreement }\end{array}$ & 0.1906 & 0.1754 & 0.3278 & -0.0114 & -0.0194 & 0.0117 \\
\hline $\begin{array}{l}\text { Percent Lower Middle } \\
\text { Class in Favor of } \\
\text { Agreement }\end{array}$ & 0.1979 & 0.1745 & 0.3275 & -0.0016 & -0.0156 & 0.0159 \\
\hline $\begin{array}{l}\text { Percent Upper Middle } \\
\text { Class in Favor of } \\
\text { Agreement }\end{array}$ & 0.2015 & 0.1692 & 0.3150 & 0.0094 & -0.0094 & 0.0173 \\
\hline $\begin{array}{l}\text { Percent Upper Class in } \\
\text { Favor of Agreement }\end{array}$ & 0.1805 & 0.1510 & 0.2809 & 0.0019 & -0.0116 & 0.0075 \\
\hline $\begin{array}{l}\text { Total Contributions in } \\
\text { Favor }\end{array}$ & 0.3369 & 0.1399 & 0.3696 & 0.3050 & 0.1640 & 0.2741 \\
\hline $\begin{array}{l}\text { Total Contributions } \\
\text { Against }\end{array}$ & 0.0833 & 0.1761 & 0.1141 & 0.0379 & 0.1739 & 0.0733 \\
\hline $\begin{array}{l}\text { Member of President's } \\
\text { Party }\end{array}$ & -0.0023 & -0.0495 & -0.0075 & -0.0017 & -0.0583 & 0.0167 \\
\hline No High School & 0.6317 & 0.3157 & 0.1424 & 0.7274 & 0.4382 & 0.2905 \\
\hline High School & -0.0753 & -0.0743 & -0.1533 & -0.0411 & -0.1310 & -0.2352 \\
\hline College & -0.0047 & 0.1148 & 0.1512 & -0.0683 & 0.0451 & 0.1123 \\
\hline Mean Income & 0.0484 & -0.0592 & 0.3056 & -0.0043 & -0.1349 & 0.2148 \\
\hline $\begin{array}{l}\text { Exports to Country(ies) in } \\
\text { Agreement }\end{array}$ & 0.1521 & -0.0228 & 0.1867 & 0.1455 & -0.1039 & 0.2588 \\
\hline CAFTA-DR & -0.1655 & -0.1990 & -0.3001 & 0.0000 & 0.0000 & 0.0000 \\
\hline Peru & -0.0759 & -0.0274 & -0.0868 & 0.0000 & 0.0000 & 0.0000 \\
\hline Korea & 0.1207 & 0.1186 & 0.1860 & 0.0000 & 0.0000 & 0.0000 \\
\hline $\mathrm{N}$ & 400 & 182 & 218 & 400 & 200 & 200 \\
\hline
\end{tabular}




\section{Appendix 6: Including Votes on Prior Agreements}

Results for All States, and High and Low Inequality States Using Gini Coefficient to Measure Inequality

\begin{tabular}{|c|c|c|c|}
\hline & All & Low Inequality & High Inequality \\
\hline Percent Lower Class in Favor of & -0.56 & 0.41 & $-2.88^{\circ}$ \\
\hline Agreement & $(0.66)$ & $(1.02)$ & $(1.63)$ \\
\hline Percent Lower Middle Class in Favor of & 0.78 & -1.73 & $5.75^{*}$ \\
\hline Agreement & $(0.98)$ & $(1.47)$ & $(2.58)$ \\
\hline Percent Upper Middle Class in Favor of & 0.09 & 0.78 & -2.54 \\
\hline Agreement & $(0.76)$ & $(1.16)$ & $(2.14)$ \\
\hline Percent Upper Class in Favor of & -0.25 & 0.72 & -0.59 \\
\hline Agreement & $(0.43)$ & $(0.63)$ & $(1.08)$ \\
\hline \multirow[t]{2}{*}{ Inequality (Gini Coefficient) } & -19.87 & -29.22 & -68.33 \\
\hline & $(17.6)$ & $(42.24)$ & $(45.06)$ \\
\hline \multirow[t]{2}{*}{ Member of President's Party } & 0.48 & 0.7 & 1.15 \\
\hline & $(0.41)$ & $(0.61)$ & $(0.88)$ \\
\hline \multirow[t]{2}{*}{ Total Contributions in Favor } & 0.08 & 0.26 & 0.17 \\
\hline & $(0.09)$ & $(0.18)$ & $(0.16)$ \\
\hline \multirow[t]{2}{*}{ Total Contributions Against } & $-4.09 * * *$ & $-3.72 * *$ & $-7.41 * * *$ \\
\hline & $(0.98)$ & $(1.44)$ & $(2.13)$ \\
\hline \multirow[t]{2}{*}{ No High School } & 9.65 & -23 & 18.93 \\
\hline & $(12.54)$ & $(23.12)$ & $(22.21)$ \\
\hline \multirow[t]{2}{*}{ High School } & $-15.4^{\circ}$ & -28.84 & -12.45 \\
\hline & $(8.54)$ & $(17.73)$ & $(15.14)$ \\
\hline \multirow[t]{2}{*}{ College } & 2.93 & -22.55 & 33.46 \\
\hline & $(12.05)$ & $(17.15)$ & $(25.19)$ \\
\hline \multirow[t]{2}{*}{ Mean Income } & -0.33 & 0.79 & -0.75 \\
\hline & $(0.41)$ & $(0.71)$ & $(0.91)$ \\
\hline \multirow[t]{2}{*}{ Exports to Country(ies) in Agreement } & 0.03 & -0.02 & 0.07 \\
\hline & $(0.02)$ & $(0.03)$ & $(0.04)$ \\
\hline \multirow[t]{2}{*}{ Votes on Prior Agreements } & $0.04 * * *$ & $0.04 * * *$ & $0.06^{* * *}$ \\
\hline & $(0.01)$ & $(0.01)$ & $(0.02)$ \\
\hline \multirow[t]{2}{*}{ CAFTA-DR } & 3.02 & -8.07 & 7.24 \\
\hline & $(5.51)$ & $(13.05)$ & $(10.18)$ \\
\hline \multirow[t]{2}{*}{ Peru } & 5.56 & 3.65 & 0.2 \\
\hline & $(4.91)$ & $(9.81)$ & $(7.86)$ \\
\hline \multirow[t]{2}{*}{ Korea } & $1.2^{\circ}$ & 1.44 & 1.83 \\
\hline & $(0.66)$ & $(1.02)$ & $(1.09)$ \\
\hline Constant & 9.38 & 2.43 & $57.1 *$ \\
\hline $\mathrm{N}$ & 296 & 138 & 158 \\
\hline Pseudo R-squared & 0.43 & 0.40 & 0.59 \\
\hline
\end{tabular}

Standard Errors are reported in parentheses. $* * *$ denotes significance at the 0.001 probability level $* *$ denotes significance at the 0.01 probability level; ${ }^{*}$ denotes significance at the 0.05 probability level; ${ }^{\circ}$ denotes significance at the 0.1 probability level. Colombia used as base category. 
Results for All States, and High and Low Inequality States Using Gini Coefficient Ranking to Measure Inequality

\begin{tabular}{|c|c|c|c|}
\hline & All & Low Inequality & High Inequality \\
\hline Percent Lower Class in Favor of & -0.51 & 0.2 & -2.2 \\
\hline Agreement & $(0.66)$ & $(0.97)$ & $(1.64)$ \\
\hline Percent Lower Middle Class in Favor of & 0.74 & -1.46 & $4.77^{\circ}$ \\
\hline Agreement & $(0.98)$ & $(1.44)$ & $(2.67)$ \\
\hline Percent Upper Middle Class in Favor of & 0.08 & 0.69 & -2.07 \\
\hline Agreement & $(0.77)$ & $(1.16)$ & $(2.09)$ \\
\hline Percent Upper Class in Favor of & -0.25 & 0.78 & -0.86 \\
\hline Agreement & $(0.43)$ & $(0.63)$ & $(1.08)$ \\
\hline \multirow[t]{2}{*}{ Inequality (Gini Coefficient Ranking) } & -0.01 & -0.06 & -0.05 \\
\hline & $(0.02)$ & $(0.06)$ & $(0.07)$ \\
\hline \multirow[t]{2}{*}{ Member of President's Party } & 0.5 & 0.74 & 1.12 \\
\hline & $(0.41)$ & $(0.62)$ & $(0.87)$ \\
\hline \multirow[t]{2}{*}{ Total Contributions in Favor } & 0.06 & 0.26 & 0.06 \\
\hline & $(0.08)$ & $(0.18)$ & $(0.14)$ \\
\hline \multirow[t]{2}{*}{ Total Contributions Against } & $-4.13 * * *$ & $-3.99 * *$ & $-7.89 * * *$ \\
\hline & $(0.98)$ & $(1.46)$ & $(2.23)$ \\
\hline \multirow[t]{2}{*}{ No High School } & 5.86 & -18.12 & 1.68 \\
\hline & $(12.61)$ & (22.36) & (22.45) \\
\hline \multirow[t]{2}{*}{ High School } & $-15.94^{\circ}$ & $-33.64^{\circ}$ & -17.15 \\
\hline & $(8.51)$ & (17.67) & (15.14) \\
\hline \multirow[t]{2}{*}{ College } & 0.34 & -21.74 & 16.36 \\
\hline & $(11.88)$ & $(17.02)$ & $(25.72)$ \\
\hline \multirow[t]{2}{*}{ Mean Income } & -0.3 & 0.61 & -0.43 \\
\hline & $(0.41)$ & $(0.66)$ & $(0.94)$ \\
\hline \multirow[t]{2}{*}{ Exports to Country(ies) in Agreement } & 0.02 & -0.03 & 0.05 \\
\hline & $(0.02)$ & $(0.03)$ & $(0.04)$ \\
\hline \multirow[t]{2}{*}{ Votes on Prior Agreements } & $0.04 * * *$ & $0.04 * * *$ & $0.07 * * *$ \\
\hline & $(0.01)$ & $(0.01)$ & $(0.02)$ \\
\hline \multirow[t]{2}{*}{ CAFTA-DR } & 3.67 & -7.25 & 7.35 \\
\hline & $(5.48)$ & $(12.63)$ & $(10.35)$ \\
\hline \multirow[t]{2}{*}{ Peru } & 6.06 & 5.34 & -2.41 \\
\hline & $(4.89)$ & $(9.34)$ & $(8.16)$ \\
\hline \multirow[t]{2}{*}{ Korea } & $1.21^{\circ}$ & 1.48 & $1.88^{\circ}$ \\
\hline & $(0.67)$ & $(1.03)$ & (1.09) \\
\hline Constant & 1.41 & -11.04 & $41.93^{\circ}$ \\
\hline $\mathrm{N}$ & 296 & 146 & 150 \\
\hline Pseudo R-squared & 0.42 & 0.42 & 0.57 \\
\hline
\end{tabular}

Standard Errors are reported in parentheses. ${ }^{* * *}$ denotes significance at the 0.001 probability level ${ }^{* *}$ denotes significance at the 0.01 probability level; *denotes significance at the 0.05 probability level; ${ }^{\circ}$ denotes significance at the 0.1 probability level. Colombia used as base category. 


\section{Appendix 7: Summary Statistics for Individual Trade Agreements}

\begin{tabular}{|c|c|c|c|c|c|c|c|c|c|c|c|c|}
\hline & \multicolumn{4}{|c|}{ All } & \multicolumn{4}{|c|}{ Low Inequality } & \multicolumn{4}{|c|}{ High Inequality } \\
\hline & Mean & $\begin{array}{l}\text { Std. } \\
\text { Dev. }\end{array}$ & Min. & $\operatorname{Max}$ & Mean & $\begin{array}{l}\text { Std. } \\
\text { Dev. }\end{array}$ & Min. & $\operatorname{Max}$ & Mean & $\begin{array}{l}\text { Std. } \\
\text { Dev. }\end{array}$ & Min. & Max. \\
\hline $\begin{array}{l}\text { Senator Vote in Favor } \\
\text { of Agreement }\end{array}$ & 0.55 & 0.50 & 0 & 1 & 0.55 & 0.48 & 0.50 & 0 & 0.62 & 0.49 & 0 & 1 \\
\hline $\begin{array}{l}\text { Percent Lower Class in } \\
\text { Favor of Agreement }\end{array}$ & 37.40 & 2.48 & 32.70 & 44.81 & 37.40 & 37.83 & 2.15 & 32.95 & 37.00 & 2.71 & 32.70 & 44.81 \\
\hline $\begin{array}{l}\text { Percent Lower Middle } \\
\text { Class in Favor of } \\
\text { Agreement }\end{array}$ & 39.46 & 2.49 & 34.56 & 47.05 & 39.46 & 39.61 & 2.20 & 34.56 & 39.33 & 2.74 & 34.80 & 47.05 \\
\hline $\begin{array}{l}\text { Percent Upper Middle } \\
\text { Class in Favor of } \\
\text { Agreement }\end{array}$ & 4811 & 262 & 4267 & 5592 & 48.11 & 4792 & 231 & 4267 & 4828 & 289 & 4374 & 5507 \\
\hline Percent Upper Class in & & & & & & & & & & & & \\
\hline $\begin{array}{l}\text { Favor of Agreement } \\
\text { Total Contributions }\end{array}$ & 61.73 & 2.36 & 57.45 & 68.05 & 61.73 & 61.77 & 1.97 & 57.69 & 61.69 & 2.70 & 57.45 & 68.05 \\
\hline $\begin{array}{l}\text { in Favor } \\
\text { Total Contributions }\end{array}$ & 3.49 & 2.45 & 0.01 & 15.60 & 3.49 & 2.80 & 1.75 & 0.01 & 4.12 & 2.82 & 0.50 & 15.60 \\
\hline Against & 0.19 & 0.22 & 0 & 1.09 & 0.19 & 0.19 & 0.22 & 0 & 0.20 & 0.23 & 0.01 & 1.09 \\
\hline $\begin{array}{l}\text { Inequality (Gini } \\
\text { Coefficient) }\end{array}$ & 0.45 & 0.02 & 0.41 & 0.50 & 0.45 & 0.43 & 0.01 & 0.41 & 0.46 & 0.01 & 0.45 & 0.50 \\
\hline Member of President's & & & & & & & & & & & & \\
\hline Party & 0.55 & 0.50 & 0 & 1 & 0.55 & 0.54 & 0.50 & 0 & 0.56 & 0.50 & 0 & 1 \\
\hline No High School & 0.14 & 0.04 & 0.09 & 0.22 & 0.14 & 0.12 & 0.02 & 0.09 & 0.17 & 0.03 & 0.12 & 0.22 \\
\hline High School & 0.31 & 0.04 & 0.22 & 0.42 & 0.31 & 0.31 & 0.04 & 0.24 & 0.31 & 0.04 & 0.22 & 0.42 \\
\hline Associates/Some & & & & & & & & & & & & \\
\hline College & 0.28 & 0.04 & 0.22 & 0.36 & 0.28 & 0.30 & 0.03 & 0.25 & 0.27 & 0.03 & 0.22 & 0.34 \\
\hline College & 0.26 & 0.05 & 0.17 & 0.37 & 0.26 & 0.27 & 0.04 & 0.21 & 0.26 & 0.05 & 0.17 & 0.37 \\
\hline Mean Income & 5.99 & 0.95 & 4.47 & 8.43 & 5.99 & 6.02 & 0.76 & 5.01 & 5.96 & 1.11 & 4.47 & 8.43 \\
\hline $\begin{array}{l}\text { Exports to Country(ies) } \\
\text { in Agreement }\end{array}$ & 10.06 & 14.54 & 0.13 & 68.48 & 10.06 & 2.65 & 1.81 & 0.13 & 16.90 & 17.55 & 0.53 & 68.48 \\
\hline
\end{tabular}

Summary Statistics for All Variables Gini Coefficient Ranking, CAFTA-DR

\begin{tabular}{|c|c|c|c|c|c|c|c|c|c|c|c|c|}
\hline & \multicolumn{4}{|c|}{ All } & \multicolumn{4}{|c|}{ Low Inequality } & \multicolumn{4}{|c|}{ High Inequality } \\
\hline & Mean & $\begin{array}{l}\text { Std. } \\
\text { Dev. }\end{array}$ & Min. & Max. & Mean & $\begin{array}{l}\text { Std. } \\
\text { Dev. }\end{array}$ & Min. & Max. & Mean & $\begin{array}{l}\text { Std. } \\
\text { Dev. }\end{array}$ & Min. & Max. \\
\hline $\begin{array}{l}\text { Senator Vote in Favor } \\
\text { of Agreement }\end{array}$ & 0.55 & 0.50 & 0 & 1 & 0.46 & 0.50 & 0 & 1 & 0.64 & 0.48 & 0 & 1 \\
\hline $\begin{array}{l}\text { Percent Lower Class in } \\
\text { Favor of Agreement } \\
\text { Percent Lower Middle }\end{array}$ & 37.40 & 2.48 & 32.70 & 44.81 & 37.64 & 2.32 & 32.95 & 43.20 & 37.16 & 2.63 & 32.70 & 44.81 \\
\hline $\begin{array}{l}\text { Class in Favor of } \\
\text { Agreement }\end{array}$ & 39.46 & 2.49 & 34.56 & 47.05 & 39.41 & 2.36 & 34.56 & 44.46 & 39.51 & 2.64 & 35.08 & 47.05 \\
\hline $\begin{array}{l}\text { Percent Upper Middle } \\
\text { Class in Favor of } \\
\text { Agreement }\end{array}$ & 48.11 & 2.62 & 42.67 & 55.92 & 47.76 & 2.41 & 42.67 & 51.93 & 48.46 & 2.79 & 43.77 & 55.92 \\
\hline $\begin{array}{l}\text { Percent Upper Class in } \\
\text { Favor of Agreement } \\
\text { Total Contributions }\end{array}$ & 61.73 & 2.36 & 57.45 & 68.05 & 61.60 & 2.11 & 57.45 & 65.15 & 61.86 & 2.61 & 57.71 & 68.05 \\
\hline $\begin{array}{l}\text { in Favor } \\
\text { Total Contributions }\end{array}$ & 3.49 & 2.45 & 0.01 & 15.60 & 2.77 & 1.74 & 0.01 & 8.17 & 4.21 & 2.83 & 0.50 & 15.60 \\
\hline $\begin{array}{l}\text { Against } \\
\text { Inequality (Gini }\end{array}$ & 0.19 & 0.22 & 0 & 1.09 & 0.19 & 0.22 & 0 & 0.83 & 0.19 & 0.23 & 0.01 & 1.09 \\
\hline $\begin{array}{l}\text { Coefficient Ranking) } \\
\text { Member of President's }\end{array}$ & 25.50 & 14.50 & 1 & 50.00 & 13.00 & 7.28 & 1 & 25.00 & 38.00 & 7.28 & 26.00 & 50.00 \\
\hline Party & 0.55 & 0.50 & 0 & 1 & 0.52 & 0.50 & 0 & 1 & 0.58 & 0.50 & 0 & 1 \\
\hline No High School & 0.14 & 0.04 & 0.09 & 0.22 & 0.12 & 0.02 & 0.09 & 0.17 & 0.17 & 0.03 & 0.12 & 0.22 \\
\hline $\begin{array}{l}\text { High School } \\
\text { Associates/Some }\end{array}$ & 0.31 & 0.04 & 0.22 & 0.42 & 0.31 & 0.04 & 0.24 & 0.37 & 0.31 & 0.04 & 0.22 & 0.42 \\
\hline College & 0.28 & 0.04 & 0.22 & 0.36 & 0.30 & 0.03 & 0.25 & 0.36 & 0.27 & 0.03 & 0.22 & 0.34 \\
\hline College & 0.26 & 0.05 & 0.17 & 0.37 & 0.27 & 0.04 & 0.21 & 0.36 & 0.26 & 0.05 & 0.17 & 0.37 \\
\hline Mean Income & 5.99 & 0.95 & 4.47 & 8.43 & 6.02 & 0.74 & 5.01 & 7.94 & 5.96 & 1.13 & 4.47 & 8.43 \\
\hline $\begin{array}{l}\text { Exports to Country(ies) } \\
\text { in Agreement }\end{array}$ & 10.06 & 14.54 & 0.13 & 68.48 & 2.68 & 1.78 & 0.13 & 7.03 & 17.45 & 17.68 & 0.53 & 68.48 \\
\hline
\end{tabular}




\begin{tabular}{|c|c|c|c|c|c|c|c|c|c|c|c|c|}
\hline & \multicolumn{4}{|c|}{ All } & \multicolumn{4}{|c|}{ Low Inequality } & \multicolumn{4}{|c|}{ High Inequality } \\
\hline & Mean & $\begin{array}{l}\text { Std. } \\
\text { Dev. }\end{array}$ & Min. & Max. & Mean & $\begin{array}{l}\text { Std. } \\
\text { Dev. }\end{array}$ & Min. & Max. & Mean & $\begin{array}{l}\text { Std. } \\
\text { Dev. }\end{array}$ & Min. & Max. \\
\hline $\begin{array}{l}\text { Senator Vote in Favor } \\
\text { of Agreement }\end{array}$ & 0.77 & 0.42 & 0 & 1 & 0.72 & 0.45 & 0 & 1 & 0.82 & 0.39 & 0 & 1 \\
\hline $\begin{array}{l}\text { Percent Lower Class in } \\
\text { Favor of A greement }\end{array}$ & 32.32 & 1.73 & 2885 & 3644 & 3239 & 132 & 3000 & 3487 & 3224 & 207 & 2885 & 3644 \\
\hline $\begin{array}{l}\text { Percent Lower Middle } \\
\text { Class in Favor of } \\
\text { Agreement }\end{array}$ & 33.10 & 1.73 & 29.81 & 37.61 & 33.00 & 1.30 & 30.65 & 35.18 & 33.19 & 2.09 & 29.81 & 37.61 \\
\hline $\begin{array}{l}\text { Percent Upper Middle } \\
\text { Class in Favor of } \\
\text { A oreement }\end{array}$ & 3799 & 188 & 3461 & 4280 & 3770 & 136 & 3552 & 40.69 & 3820 & 226 & 3461 & 4280 \\
\hline Percent Upper Class in & & & & & & & & & & & & \\
\hline $\begin{array}{l}\text { Favor of Agreement } \\
\text { Total Contributions }\end{array}$ & 46.79 & 1.71 & 43.27 & 51.11 & 46.69 & 1.23 & 44.43 & 48.75 & 46.88 & 2.10 & 43.27 & 51.11 \\
\hline $\begin{array}{l}\text { in Favor } \\
\text { Total Contributions }\end{array}$ & 3.88 & 2.56 & 0.01 & 17.48 & 3.29 & 2.00 & 0.01 & 8.70 & 4.47 & 2.92 & 0.07 & 17.48 \\
\hline $\begin{array}{l}\text { Against } \\
\text { Inequality (Gini }\end{array}$ & 0.23 & 0.23 & 0 & 1.05 & 0.24 & 0.24 & 0 & 1.01 & 0.23 & 0.23 & 0 & 1.05 \\
\hline Coefficient) & 0.45 & 0.02 & 0.41 & 0.50 & 0.43 & 0.01 & 0.41 & 0.45 & 0.47 & 0.01 & 0.45 & 0.50 \\
\hline Member of President's & & & & & & & & & & & & \\
\hline Party & 0.49 & 0.50 & 0 & 1 & 0.48 & 0.50 & 0 & 1 & 0.50 & 0.51 & 0 & 1 \\
\hline No High School & 0.14 & 0.04 & 0.09 & 0.22 & 0.11 & 0.02 & 0.09 & 0.17 & 0.17 & 0.03 & 0.11 & 0.22 \\
\hline High School & 0.31 & 0.04 & 0.23 & 0.41 & 0.31 & 0.03 & 0.26 & 0.37 & 0.31 & 0.04 & 0.23 & 0.41 \\
\hline Associates/Some & & & & & & & & & & & & \\
\hline College & 0.28 & 0.04 & 0.22 & 0.36 & 0.30 & 0.03 & 0.24 & 0.36 & 0.26 & 0.02 & 0.22 & 0.29 \\
\hline College & 0.27 & 0.05 & 0.17 & 0.38 & 0.27 & 0.03 & 0.22 & 0.35 & 0.26 & 0.06 & 0.17 & 0.38 \\
\hline Mean Income & 6.63 & 1.05 & 4.91 & 9.27 & 6.64 & 0.84 & 5.50 & 8.85 & 6.62 & 1.24 & 4.91 & 9.27 \\
\hline $\begin{array}{l}\text { Exports to Country(ies) } \\
\text { in Agreement }\end{array}$ & 1.36 & 2.02 & 0 & 9.93 & 0.67 & 0.52 & 0 & 1.99 & 2.06 & 2.64 & 0.08 & 9.93 \\
\hline
\end{tabular}

\begin{tabular}{|c|c|c|c|c|c|c|c|c|c|c|c|c|}
\hline & \multicolumn{4}{|c|}{ All } & \multicolumn{4}{|c|}{ Low Inequality } & \multicolumn{4}{|c|}{ High Inequality } \\
\hline & Mean & $\begin{array}{l}\text { Std. } \\
\text { Dev. }\end{array}$ & Min. & Max. & Mean & $\begin{array}{c}\text { Std. } \\
\text { Dev. }\end{array}$ & Min. & Max. & Mean & $\begin{array}{l}\text { Std. } \\
\text { Dev. }\end{array}$ & Min. & Max. \\
\hline $\begin{array}{l}\text { Percent Lower Class in } \\
\text { Favor of Agreement }\end{array}$ & 32.32 & 1.73 & 28.85 & 36.44 & 32.39 & 1.32 & 30.00 & 34.87 & 32.24 & 2.07 & 28.85 & 36.44 \\
\hline $\begin{array}{l}\text { Percent Lower Middle } \\
\text { Class in Favor of } \\
\text { Agreement }\end{array}$ & 33.10 & 1.73 & 29.81 & 37.61 & 33.00 & 1.30 & 30.65 & 35.18 & 33.19 & 2.09 & 29.81 & 37.61 \\
\hline $\begin{array}{l}\text { Percent Upper Middle } \\
\text { Class in Favor of } \\
\text { Agreement }\end{array}$ & 37.99 & 1.88 & 34.61 & 42.80 & 37.70 & 1.36 & 35.52 & 40.69 & 38.29 & 2.26 & 34.61 & 42.80 \\
\hline $\begin{array}{l}\text { Percent Upper Class in } \\
\text { Favor of Agreement } \\
\text { Total Contributions }\end{array}$ & 46.79 & 1.71 & 43.27 & 51.11 & 46.69 & 1.23 & 44.43 & 48.75 & 46.88 & 2.10 & 43.27 & 51.11 \\
\hline Against & 0.23 & 0.23 & 0 & 1.05 & 0.24 & 0.24 & 0 & 1.01 & 0.23 & 0.23 & 0 & 1.05 \\
\hline $\begin{array}{l}\text { Inequality (Gini } \\
\text { Coefficient Ranking) } \\
\text { Member of President's }\end{array}$ & 25.50 & 14.50 & 1 & 50.00 & 13.00 & 7.28 & 1 & 25.00 & 38.00 & 7.28 & 26.00 & 50.00 \\
\hline Party & 0.49 & 0.50 & 0 & 1 & 0.48 & 0.50 & 0 & 1 & 0.50 & 0.51 & 0 & 1 \\
\hline No High School & 0.14 & 0.04 & 0.09 & 0.22 & 0.11 & 0.02 & 0.09 & 0.17 & 0.17 & 0.03 & 0.11 & 0.22 \\
\hline High School & 0.31 & 0.04 & 0.23 & 0.41 & 0.31 & 0.03 & 0.26 & 0.37 & 0.31 & 0.04 & 0.23 & 0.41 \\
\hline Associates/Some & & & & & & & & & & & & \\
\hline College & 0.28 & 0.04 & 0.22 & 0.36 & 0.30 & 0.03 & 0.24 & 0.36 & 0.26 & 0.02 & 0.22 & 0.29 \\
\hline College & 0.27 & 0.05 & 0.17 & 0.38 & 0.27 & 0.03 & 0.22 & 0.35 & 0.26 & 0.06 & 0.17 & 0.38 \\
\hline Mean Income & 6.63 & 1.05 & 4.91 & 9.27 & 6.64 & 0.84 & 5.50 & 8.85 & 6.62 & 1.24 & 4.91 & 9.27 \\
\hline $\begin{array}{l}\text { Exports to Country(ies) } \\
\text { in Agreement }\end{array}$ & 1.36 & 2.02 & 0 & 9.93 & 0.67 & 0.52 & 0 & 1.99 & 2.06 & 2.64 & 0.08 & 9.93 \\
\hline
\end{tabular}




\begin{tabular}{|c|c|c|c|c|c|c|c|c|c|c|c|c|}
\hline & \multicolumn{4}{|c|}{ All } & \multicolumn{4}{|c|}{ Low Inequality } & \multicolumn{4}{|c|}{ High Inequality } \\
\hline & Mean & $\begin{array}{l}\text { Std. } \\
\text { Dev. }\end{array}$ & Min. & Max. & Mean & $\begin{array}{l}\text { Std. } \\
\text { Dev. }\end{array}$ & Min. & Max. & Mean & $\begin{array}{l}\text { Std. } \\
\text { Dev. }\end{array}$ & Min. & Max. \\
\hline $\begin{array}{c}\text { Senator Vote in Favor } \\
\text { of Agreement }\end{array}$ & 0.66 & 0.48 & 0 & 1 & 0.67 & 0.48 & 0 & 1 & 0.66 & 0.48 & 0 & 1 \\
\hline Percent Lower Class in & & & & & & & & & & & & \\
\hline $\begin{array}{l}\text { Favor of Agreement } \\
\text { Percent Lower Middle }\end{array}$ & 75.43 & 1.44 & 71.31 & 79.17 & 75.84 & 1.21 & 74.28 & 79.17 & 75.13 & 1.53 & 71.31 & 77.51 \\
\hline $\begin{array}{l}\text { Class in Favor of } \\
\text { Agreement }\end{array}$ & 76.33 & 1.37 & 72.29 & 79.42 & 76.56 & 1.16 & 75.20 & 79.42 & 76.16 & 1.50 & 72.29 & 78.53 \\
\hline $\begin{array}{l}\text { Percent Upper Middle } \\
\text { Class in Favor of }\end{array}$ & & & & & & & & & & & & \\
\hline $\begin{array}{l}\text { Agreement } \\
\text { Percent Upper Class in }\end{array}$ & 79.54 & 1.23 & 76.04 & 82.16 & 79.58 & 1.05 & 77.96 & 82.16 & 79.51 & 1.36 & 76.04 & 81.91 \\
\hline $\begin{array}{l}\text { Favor of Agreement } \\
\text { Total Contributions }\end{array}$ & 84.43 & 0.97 & 81.53 & 87.02 & 84.51 & 0.90 & 83.29 & 87.02 & 84.37 & 1.03 & 81.53 & 85.83 \\
\hline $\begin{array}{l}\text { in Favor } \\
\text { Total Contributions }\end{array}$ & 3.86 & 2.71 & 0 & 14.15 & 3.23 & 2.34 & 0 & 11.81 & 4.32 & 2.89 & 0.32 & 14.15 \\
\hline Against & 0.20 & 0.23 & 0 & 1.06 & 0.20 & 0.24 & 0 & 1.06 & 0.21 & 0.22 & 0 & 0.88 \\
\hline $\begin{array}{l}\text { Inequality (Gini } \\
\text { Coefficient) }\end{array}$ & 0.46 & 0.02 & 0.41 & 0.50 & 0.44 & 0.01 & 0.41 & 0.45 & 0.47 & 0.01 & 0.46 & 0.50 \\
\hline Member of President's & & & & & & & & & & & & \\
\hline Party & 0.53 & 0.50 & 0 & 1 & 0.52 & 0.51 & 0 & 1 & 0.53 & 0.50 & 0 & 1 \\
\hline No High School & 0.13 & 0.03 & 0.08 & 0.19 & 0.10 & 0.02 & 0.08 & 0.16 & 0.14 & 0.03 & 0.10 & 0.19 \\
\hline High School & 0.30 & 0.04 & 0.21 & 0.42 & 0.29 & 0.03 & 0.24 & 0.36 & 0.30 & 0.05 & 0.21 & 0.42 \\
\hline Associates/Some & & & & & & & & & & & & \\
\hline College & 0.30 & 0.04 & 0.23 & 0.38 & 0.32 & 0.04 & 0.26 & 0.38 & 0.29 & 0.03 & 0.23 & 0.35 \\
\hline College & 0.28 & 0.05 & 0.19 & 0.39 & 0.29 & 0.04 & 0.23 & 0.37 & 0.27 & 0.05 & 0.19 & 0.39 \\
\hline Mean Income & 6.76 & 1.05 & 5.14 & 9.22 & 6.89 & 0.88 & 5.62 & 9.09 & 6.67 & 1.15 & 5.14 & 9.22 \\
\hline $\begin{array}{l}\text { Exports to Country(ies) } \\
\text { in Agreement }\end{array}$ & 5.32 & 8.16 & 0.04 & 35.50 & 2.44 & 1.84 & 0.04 & 7.18 & 7.40 & 10.13 & 0.15 & 35.50 \\
\hline
\end{tabular}

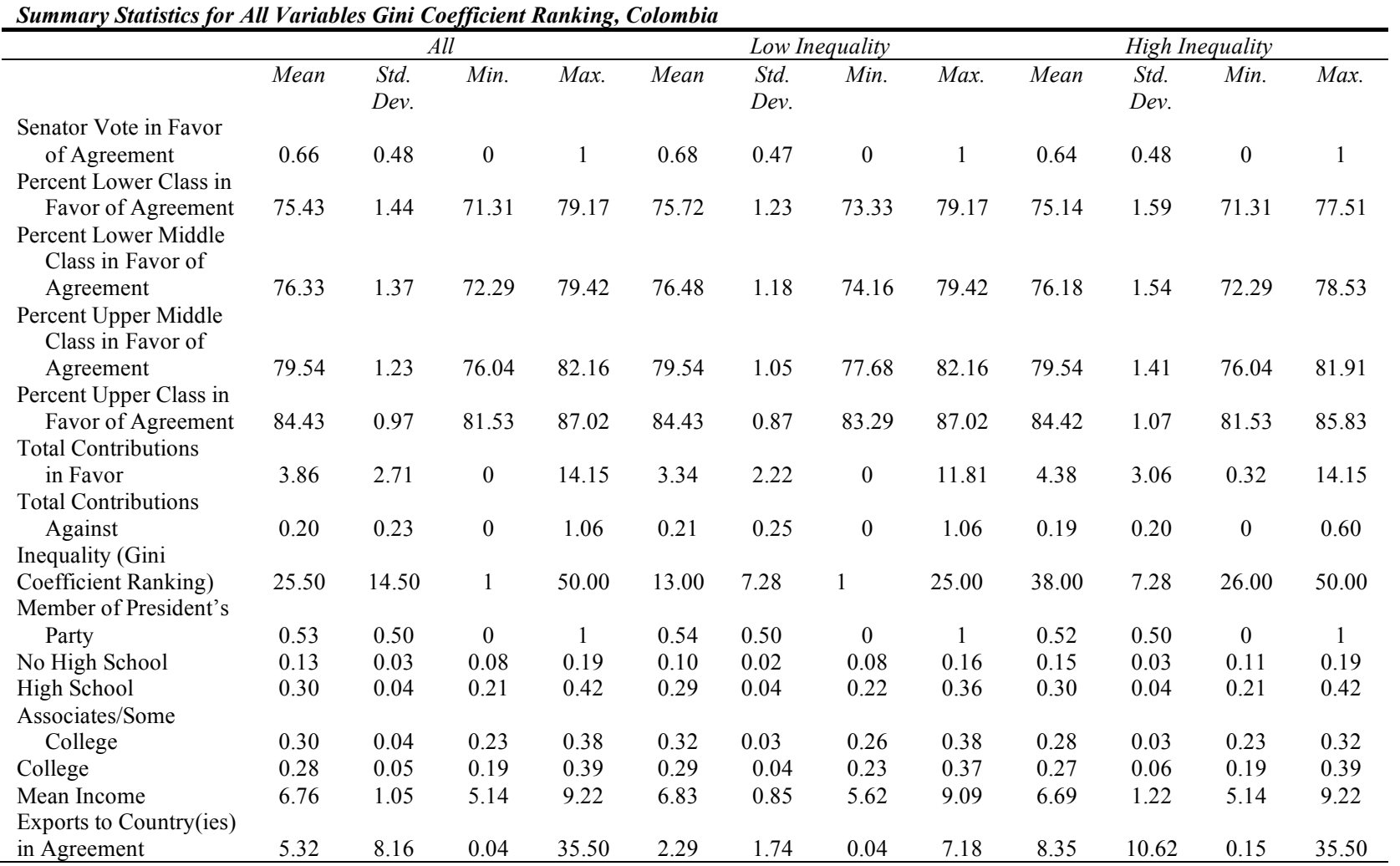




\begin{tabular}{|c|c|c|c|c|c|c|c|c|c|c|c|c|}
\hline & \multicolumn{4}{|c|}{ All } & \multicolumn{4}{|c|}{ Low Inequality } & \multicolumn{4}{|c|}{ High Inequality } \\
\hline & Mean & $\begin{array}{l}\text { Std. } \\
\text { Dev. }\end{array}$ & Min. & Max. & Mean & $\begin{array}{l}\text { Std. } \\
\text { Dev. }\end{array}$ & Min. & Max. & Mean & $\begin{array}{l}\text { Std. } \\
\text { Dev. }\end{array}$ & Min. & Max. \\
\hline $\begin{array}{l}\text { Senator Vote in Favor } \\
\text { of Agreement }\end{array}$ & 0.83 & 0.38 & 0 & 1 & 0.83 & 0.38 & 0 & 1 & 0.83 & 0.38 & 0 & 1 \\
\hline Percent Lower Class in & & & & & & & & & & & & \\
\hline $\begin{array}{l}\text { Favor of Agreement } \\
\text { Percent Lower Middle }\end{array}$ & 75.43 & 1.44 & 71.31 & 79.17 & 75.84 & 1.21 & 74.28 & 79.17 & 75.13 & 1.53 & 71.31 & 77.51 \\
\hline $\begin{array}{l}\text { Class in Favor of } \\
\text { Agreement }\end{array}$ & 76.33 & 1.37 & 72.29 & 79.42 & 76.56 & 1.16 & 75.20 & 79.42 & 76.16 & 1.50 & 72.29 & 78.53 \\
\hline $\begin{array}{l}\text { Percent Upper Middle } \\
\text { Class in Favor of }\end{array}$ & & & & & & & & & & & & \\
\hline $\begin{array}{l}\text { Agreement } \\
\text { Percent Upper Class in }\end{array}$ & 79.54 & 1.23 & 76.04 & 82.16 & 79.58 & 1.05 & 77.96 & 82.16 & 79.51 & 1.36 & 76.04 & 81.91 \\
\hline $\begin{array}{l}\text { Favor of Agreement } \\
\text { Total Contributions }\end{array}$ & 84.43 & 0.97 & 81.53 & 87.02 & 84.51 & 0.90 & 83.29 & 87.02 & 84.37 & 1.03 & 81.53 & 85.83 \\
\hline $\begin{array}{l}\text { in Favor } \\
\text { Total Contributions }\end{array}$ & 3.86 & 2.71 & 0 & 14.15 & 3.23 & 2.34 & 0 & 11.81 & 4.32 & 2.89 & 0.32 & 14.15 \\
\hline Against & 0.20 & 0.23 & 0 & 1.06 & 0.20 & 0.24 & 0 & 1.06 & 0.21 & 0.22 & 0 & 0.88 \\
\hline $\begin{array}{l}\text { Inequality (Gini } \\
\text { Coefficient) }\end{array}$ & 0.46 & 0.02 & 0.41 & 0.50 & 0.44 & 0.01 & 0.41 & 0.45 & 0.47 & 0.01 & 0.46 & 0.50 \\
\hline Member of President's & & & & & & & & & & & & \\
\hline Party & 0.53 & 0.50 & 0 & 1 & 0.52 & 0.51 & 0 & 1 & 0.53 & 0.50 & 0 & 1 \\
\hline No High School & 0.13 & 0.03 & 0.08 & 0.19 & 0.10 & 0.02 & 0.08 & 0.16 & 0.14 & 0.03 & 0.10 & 0.19 \\
\hline High School & 0.30 & 0.04 & 0.21 & 0.42 & 0.29 & 0.03 & 0.24 & 0.36 & 0.30 & 0.05 & 0.21 & 0.42 \\
\hline Associates/Some & & & & & & & & & & & & \\
\hline College & 0.30 & 0.04 & 0.23 & 0.38 & 0.32 & 0.04 & 0.26 & 0.38 & 0.29 & 0.03 & 0.23 & 0.35 \\
\hline College & 0.28 & 0.05 & 0.19 & 0.39 & 0.29 & 0.04 & 0.23 & 0.37 & 0.27 & 0.05 & 0.19 & 0.39 \\
\hline Mean Income & 6.76 & 1.05 & 5.14 & 9.22 & 6.89 & 0.88 & 5.62 & 9.09 & 6.67 & 1.15 & 5.14 & 9.22 \\
\hline $\begin{array}{l}\text { Exports to Country(ies) } \\
\text { in Agreement }\end{array}$ & 24.00 & 21.17 & 2.23 & 90.76 & 28.20 & 26.45 & 2.23 & 90.76 & 20.96 & 15.89 & 3.25 & 71.19 \\
\hline
\end{tabular}

\begin{tabular}{|c|c|c|c|c|c|c|c|c|c|c|c|c|}
\hline & \multicolumn{4}{|c|}{ All } & \multicolumn{4}{|c|}{ Low Inequality } & \multicolumn{4}{|c|}{ High Inequality } \\
\hline & Mean & $\begin{array}{l}\text { Std. } \\
\text { Dev. }\end{array}$ & Min. & Max. & Mean & $\begin{array}{l}\text { Std. } \\
\text { Dev. }\end{array}$ & Min. & Max. & Mean & $\begin{array}{l}\text { Std. } \\
\text { Dev. }\end{array}$ & Min. & Max. \\
\hline $\begin{array}{l}\text { Senator Vote in Favor } \\
\text { of Agreement }\end{array}$ & 0.83 & 0.38 & 0 & 1 & 0.82 & 0.39 & 0 & 1 & 0.84 & 0.37 & 0 & 1 \\
\hline $\begin{array}{l}\text { Percent Lower Class in } \\
\text { Favor of Agreement }\end{array}$ & 75.43 & 1.44 & 71.31 & 79.17 & 75.72 & 1.23 & 73.33 & 79.17 & 75.14 & 1.59 & 71.31 & 77.51 \\
\hline $\begin{array}{l}\text { Percent Lower Middle } \\
\text { Class in Favor of } \\
\text { Agreement }\end{array}$ & 76.33 & 1.37 & 72.29 & 79.42 & 76.48 & 1.18 & 74.16 & 79.42 & 76.18 & 1.54 & 72.29 & 78.53 \\
\hline $\begin{array}{l}\text { Percent Upper Middle } \\
\text { Class in Favor of } \\
\text { Agreement }\end{array}$ & 79.54 & 1.23 & 76.04 & 82.16 & 79.54 & 1.05 & 77.68 & 82.16 & 79.54 & 1.41 & 76.04 & 81.91 \\
\hline $\begin{array}{l}\text { Percent Upper Class in } \\
\text { Favor of Agreement }\end{array}$ & 84.43 & 0.97 & 81.53 & 87.02 & 84.43 & 0.87 & 83.29 & 87.02 & 84.42 & 1.07 & 81.53 & 85.83 \\
\hline $\begin{array}{l}\text { Total Contributions } \\
\text { in Favor } \\
\text { Total Contributions }\end{array}$ & 3.86 & 2.71 & 0 & 14.15 & 3.34 & 2.22 & 0 & 11.81 & 4.38 & 3.06 & 0.32 & 14.15 \\
\hline Against & 0.20 & 0.23 & 0 & 1.06 & 0.21 & 0.25 & 0 & 1.06 & 0.19 & 0.20 & 0 & 0.60 \\
\hline $\begin{array}{l}\text { Inequality (Gini } \\
\text { Coefficient Ranking) } \\
\text { Member of President's }\end{array}$ & 25.50 & 14.50 & 1 & 50.00 & 13.00 & 7.28 & 1 & 25.00 & 38.00 & 7.28 & 26.00 & 50.00 \\
\hline Party & 0.53 & 0.50 & 0 & 1 & 0.54 & 0.50 & 0 & 1 & 0.52 & 0.50 & 0 & 1 \\
\hline No High School & 0.13 & 0.03 & 0.08 & 0.19 & 0.10 & 0.02 & 0.08 & 0.16 & 0.15 & 0.03 & 0.11 & 0.19 \\
\hline High School & 0.30 & 0.04 & 0.21 & 0.42 & 0.29 & 0.04 & 0.22 & 0.36 & 0.30 & 0.04 & 0.21 & 0.42 \\
\hline Associates/Some & & & & & & & & & & & & \\
\hline College & 0.30 & 0.04 & 0.23 & 0.38 & 0.32 & 0.03 & 0.26 & 0.38 & 0.28 & 0.03 & 0.23 & 0.32 \\
\hline College & 0.28 & 0.05 & 0.19 & 0.39 & 0.29 & 0.04 & 0.23 & 0.37 & 0.27 & 0.06 & 0.19 & 0.39 \\
\hline Mean Income & 6.76 & 1.05 & 5.14 & 9.22 & 6.83 & 0.85 & 5.62 & 9.09 & 6.69 & 1.22 & 5.14 & 9.22 \\
\hline $\begin{array}{l}\text { Exports to Country(ies) } \\
\text { in Agreement }\end{array}$ & 24.00 & 21.17 & 2.23 & 90.76 & 26.87 & 25.33 & 2.23 & 90.76 & 21.14 & 15.71 & 3.25 & 71.19 \\
\hline
\end{tabular}




\section{Appendix 8: Regression Results for Individual Trade Agreements}

\begin{tabular}{|c|c|c|c|}
\hline & All & Low Inequality & High Inequality \\
\hline Percent Lower Class in Favor of Agreement & $\begin{array}{l}-1.18 \\
(0.95)\end{array}$ & $\begin{array}{c}3.54 \\
(2.57)\end{array}$ & $\begin{array}{c}-4.02 \\
(3.71)\end{array}$ \\
\hline Percent Lower Middle Class in Favor of & -0.07 & $-9.2 *$ & 5.1 \\
\hline Agreement & $(1.19)$ & $(4.49)$ & $(3.32)$ \\
\hline \multirow[t]{2}{*}{ Percent Upper Middle Class in Favor of Agreement } & 0.49 & 0.79 & 3.51 \\
\hline & $(1.03)$ & $(2.05)$ & $(4.79)$ \\
\hline \multirow[t]{2}{*}{ Percent Upper Class in Favor of Agreement } & 0.83 & $5.03^{\circ}$ & -4.7 \\
\hline & $(0.74)$ & $(3.05)$ & $(3.31)$ \\
\hline \multirow[t]{2}{*}{ Inequality (Gini Coefficient) } & -48.2 & 18.69 & $-212.12^{\circ}$ \\
\hline & $(31.81)$ & $(109.01)$ & $(114.72)$ \\
\hline \multirow[t]{2}{*}{ Member of President's Party } & 1.28 & $5.32 *$ & 0.53 \\
\hline & $(0.8)$ & $(2.56)$ & $(2.33)$ \\
\hline \multirow[t]{2}{*}{ Total Contributions in Favor } & $0.31 *$ & $1.28 *$ & $0.82^{\circ}$ \\
\hline & $(0.15)$ & $(0.64)$ & $(0.43)$ \\
\hline \multirow[t]{2}{*}{ Total Contributions Against } & -2.99 & -5.27 & -9.36 \\
\hline & $(1.97)$ & $(4.57)$ & $(5.91)$ \\
\hline \multirow[t]{2}{*}{ No High School } & 3.64 & -47.56 & 3.58 \\
\hline & $(22.1)$ & $(50.3)$ & $(56.68)$ \\
\hline \multirow[t]{2}{*}{ High School } & $-43.24 *$ & $-108.74^{\circ}$ & -54.06 \\
\hline & $(17.03)$ & $(57.02)$ & $(42.68)$ \\
\hline \multirow[t]{2}{*}{ College } & -21.02 & -76.96 & 22.89 \\
\hline & $(23.87)$ & $(64.1)$ & $(46.8)$ \\
\hline \multirow[t]{2}{*}{ Mean Income } & -0.48 & $4.27^{\circ}$ & -2.06 \\
\hline & $(0.58)$ & $(2.22)$ & $(1.72)$ \\
\hline \multirow[t]{2}{*}{ Exports to Country(ies) in Agreement } & 0.01 & -0.07 & -0.08 \\
\hline & $(0.03)$ & $(0.56)$ & $(0.05)$ \\
\hline Constant & 14.07 & -97.02 & $189.26^{\circ}$ \\
\hline $\mathrm{N}$ & 100 & 48 & 52 \\
\hline Pseudo R-squared & 0.34 & 0.56 & 0.6 \\
\hline
\end{tabular}


CAFTA-DR: Results for All States, and High and Low Inequality States Using Gini Coefficient Ranking to Measure Inequality

\begin{tabular}{|c|c|c|c|}
\hline & All & Low Inequality & High Inequality \\
\hline Percent Lower Class in Favor of Agreement & $\begin{array}{l}-1.00 \\
(0.93)\end{array}$ & $\begin{array}{c}3.33 \\
(2.37)\end{array}$ & $\begin{array}{l}-2.92 \\
(3.22)\end{array}$ \\
\hline Percent Lower Middle Class in Favor of & -0.23 & $-9.19 *$ & 4.74 \\
\hline Agreement & $(1.18)$ & $(4.56)$ & $(3.10)$ \\
\hline Percent Upper Middle Class in Favor of & 0.47 & 0.59 & 1.45 \\
\hline Agreement & $(1.03)$ & $(2.00)$ & $(4.22)$ \\
\hline Percent Upper Class in Favor of Agreement & $\begin{array}{c}0.85 \\
(0.74)\end{array}$ & $\begin{array}{c}5.54^{\circ} \\
(2.94)\end{array}$ & $\begin{array}{l}-3.20 \\
(2.81)\end{array}$ \\
\hline Inequality (Gini Coefficient Ranking) & $\begin{array}{l}-0.05 \\
(0.04)\end{array}$ & $\begin{array}{l}-0.02 \\
(0.15)\end{array}$ & $\begin{array}{l}-0.25^{\circ} \\
(0.15)\end{array}$ \\
\hline Member of President's Party & $\begin{array}{l}1.34^{\circ} \\
(0.79)\end{array}$ & $\begin{array}{l}5.99 * \\
(2.43)\end{array}$ & $\begin{array}{c}0.50 \\
(2.32)\end{array}$ \\
\hline Total Contributions in Favor & $\begin{array}{c}0.26^{\circ} \\
(0.14)\end{array}$ & $\begin{array}{l}1.37 * \\
(0.63)\end{array}$ & $\begin{array}{c}0.6^{\circ} \\
(0.34)\end{array}$ \\
\hline Total Contributions Against & $\begin{array}{l}-3.11 \\
(1.97)\end{array}$ & $\begin{array}{l}-4.74 \\
(4.69)\end{array}$ & $\begin{array}{l}-10.93^{\circ} \\
(6.35)\end{array}$ \\
\hline No High School & $\begin{array}{c}1.76 \\
(22.22)\end{array}$ & $\begin{array}{c}-40.3 \\
(52.43)\end{array}$ & $\begin{array}{c}11.95 \\
(53.62)\end{array}$ \\
\hline High School & $\begin{array}{l}-43.53^{*} \\
(17.03)\end{array}$ & $\begin{array}{r}-112.86^{\circ} \\
(58.48)\end{array}$ & $\begin{array}{l}-52.17 \\
(38.5)\end{array}$ \\
\hline College & $\begin{array}{l}-24.31 \\
(23.69)\end{array}$ & $\begin{array}{l}-72.52 \\
(66.17)\end{array}$ & $\begin{array}{c}6.91 \\
(44.44)\end{array}$ \\
\hline Mean Income & $\begin{array}{l}-0.37 \\
(0.58)\end{array}$ & $\begin{array}{l}4.09^{\circ} \\
(2.15)\end{array}$ & $\begin{array}{l}-1.46 \\
(1.65)\end{array}$ \\
\hline Exports to Country(ies) in Agreement & $\begin{array}{c}0.01 \\
(0.03)\end{array}$ & $\begin{array}{l}-0.17 \\
(0.54)\end{array}$ & $\begin{array}{l}-0.07 \\
(0.05)\end{array}$ \\
\hline Constant & -5.82 & $-103.12^{\circ}$ & 80.67 \\
\hline $\mathrm{N}$ & 100 & 50 & 50 \\
\hline Pseudo R-squared & 0.32 & 0.57 & 0.58 \\
\hline
\end{tabular}


Peru: Results for All States, and High and Low Inequality States Using Gini Coefficient to Measure Inequality

\begin{tabular}{|c|c|c|c|}
\hline & All & Low Inequality & High Inequality $^{61}$ \\
\hline Percent Lower Class in Favor of Agreement & $\begin{array}{l}-0.21 \\
(1.48)\end{array}$ & $\begin{array}{l}1.95 \\
(2.36)\end{array}$ & - \\
\hline $\begin{array}{l}\text { Percent Lower Middle Class in Favor of } \\
\text { Agreement }\end{array}$ & $\begin{array}{c}3.52 \\
(2.31)\end{array}$ & $\begin{array}{c}1.81 \\
(3.26)\end{array}$ & - \\
\hline Percent Upper Middle Class in Favor of Agreement & $\begin{array}{l}-1.79 \\
(1.94)\end{array}$ & $\begin{array}{l}-3.22 \\
(3.16)\end{array}$ & - \\
\hline Percent Upper Class in Favor of Agreement & $\begin{array}{l}-1.09 \\
(0.97)\end{array}$ & $\begin{array}{l}-0.39 \\
(1.42)\end{array}$ & - \\
\hline Inequality (Gini Coefficient) & $\begin{array}{c}10.25 \\
(30.24)\end{array}$ & $\begin{array}{c}75.21 \\
(77.13)\end{array}$ & - \\
\hline Member of President's Party & $\begin{array}{l}2.45^{*} \\
(1.06)\end{array}$ & $\begin{array}{c}0.85 \\
(1.49)\end{array}$ & - \\
\hline Total Contributions in Favor & $\begin{array}{l}-0.08 \\
(0.14)\end{array}$ & $\begin{array}{c}0.47 \\
(0.32)\end{array}$ & - \\
\hline Total Contributions Against & $\begin{array}{l}-1.93 \\
(1.78)\end{array}$ & $\begin{array}{l}-5.47 \\
(3.39)\end{array}$ & - \\
\hline No High School & $\begin{array}{c}14.68 \\
(26.56)\end{array}$ & $\begin{array}{l}-52.26 \\
(40.64)\end{array}$ & - \\
\hline High School & $\begin{array}{c}19.03 \\
(18.97)\end{array}$ & $\begin{array}{c}28.86 \\
(38.28)\end{array}$ & - \\
\hline College & $\begin{array}{c}29.82 \\
(25.15)\end{array}$ & $\begin{array}{c}-1.1 \\
(37.98)\end{array}$ & - \\
\hline Mean Income & $\begin{array}{l}-0.63 \\
(0.73)\end{array}$ & $\begin{array}{c}2.18 \\
(1.41)\end{array}$ & - \\
\hline Exports to Country(ies) in Agreement & $\begin{array}{c}0.29 \\
(0.39)\end{array}$ & $\begin{array}{c}-0.32 \\
(1.04)\end{array}$ & - \\
\hline Constant & -5.86 & -31.77 & - \\
\hline $\mathrm{N}$ & 100 & 50 & - \\
\hline Pseudo R-squared & 0.31 & 0.32 & - \\
\hline
\end{tabular}

${ }^{61}$ Convergence not achieved, president's party was omitted from model 
Peru: Results for All States, and High and Low Inequality States Using Gini Coefficient Ranking to Measure Inequality

\begin{tabular}{|c|c|c|c|}
\hline & All & Low Inequality & High Inequality $^{62}$ \\
\hline Percent Lower Class in Favor of Agreement & $\begin{array}{l}-0.28 \\
(1.49)\end{array}$ & $\begin{array}{c}2.31 \\
(2.45)\end{array}$ & - \\
\hline Percent Lower Middle Class in Favor of & 3.49 & 3.31 & - \\
\hline Agreement & $(2.29)$ & $(3.63)$ & \\
\hline Percent Upper Middle Class in Favor of & -1.79 & -5.32 & - \\
\hline Agreement & $(1.93)$ & $(3.72)$ & \\
\hline Percent Upper Class in Favor of Agreement & $\begin{array}{l}-1.00 \\
(0.99)\end{array}$ & $\begin{array}{l}-0.04 \\
(1.50)\end{array}$ & - \\
\hline Inequality (Gini Coefficient Ranking) & $\begin{array}{c}0.03 \\
(0.04)\end{array}$ & $\begin{array}{c}0.2 \\
(0.13)\end{array}$ & - \\
\hline Member of President's Party & $\begin{array}{l}2.43 * \\
(1.07)\end{array}$ & $\begin{array}{c}0.37 \\
(1.58)\end{array}$ & - \\
\hline Total Contributions in Favor & $\begin{array}{l}-0.09 \\
(0.13)\end{array}$ & $\begin{array}{c}0.55 \\
(0.34)\end{array}$ & - \\
\hline Total Contributions Against & $\begin{array}{l}-2.01 \\
(1.82)\end{array}$ & $\begin{array}{l}-7.34^{\circ} \\
(3.96)\end{array}$ & - \\
\hline No High School & $\begin{array}{c}9.46 \\
(26.57)\end{array}$ & $\begin{array}{l}-56.04 \\
(42.51)\end{array}$ & - \\
\hline High School & $\begin{array}{c}17.38 \\
(19.06)\end{array}$ & $\begin{array}{c}39.84 \\
(39.75)\end{array}$ & - \\
\hline College & $\begin{array}{c}26.23 \\
(25.25)\end{array}$ & $\begin{array}{c}-1.91 \\
(39.32)\end{array}$ & - \\
\hline Mean Income & $\begin{array}{l}-0.59 \\
(0.74)\end{array}$ & $\begin{array}{c}3.12 \\
(1.67)\end{array}$ & - \\
\hline Exports to Country(ies) in Agreement & $\begin{array}{c}0.24 \\
(0.38)\end{array}$ & $\begin{array}{l}-0.61 \\
(1.09)\end{array}$ & - \\
\hline Constant & -1.19 & -8.26 & - \\
\hline $\mathrm{N}$ & 100 & 200 & - \\
\hline Pseudo R-squared & 0.31 & 0.36 & - \\
\hline
\end{tabular}

${ }^{62}$ Convergence not achieved, president's party was omitted from model 


\begin{tabular}{|c|c|c|c|}
\hline & All & Low Inequality & High Inequality ${ }^{63}$ \\
\hline Percent Lower Class in Favor of Agreement & $\begin{array}{l}-0.29 \\
(1.83)\end{array}$ & $\begin{array}{c}9.27 \\
(6.92)\end{array}$ & - \\
\hline Percent Lower Middle Class in Favor of & $6.97 *$ & -7.29 & - \\
\hline Agreement & $(4.2)$ & $(10.39)$ & \\
\hline Percent Upper Middle Class in Favor of Agreement & $\begin{array}{c}-5.5 \\
(3.45)\end{array}$ & $\begin{array}{l}-0.37 \\
(7.35)\end{array}$ & - \\
\hline Percent Upper Class in Favor of Agreement & $\begin{array}{l}-2.11 \\
(1.57)\end{array}$ & $\begin{array}{l}-2.55 \\
(3.59)\end{array}$ & - \\
\hline Inequality (Gini Coefficient) & $\begin{array}{l}-55.62 \\
(34.33)\end{array}$ & $\begin{array}{l}-401.76^{*} \\
(192.26)\end{array}$ & - \\
\hline Member of President's Party & $\begin{array}{l}-0.95 \\
(1.34)\end{array}$ & $\begin{array}{r}-10.57 \\
(5.73)\end{array}$ & - \\
\hline Total Contributions in Favor & $\begin{array}{l}0.45^{\circ} \\
(0.24)\end{array}$ & $\begin{array}{c}0.7 \\
(0.61)\end{array}$ & - \\
\hline Total Contributions Against & $\begin{array}{c}-10.49 * * \\
(3.42)\end{array}$ & $\begin{array}{c}-8.7 \\
(6.42)\end{array}$ & - \\
\hline No High School & $\begin{array}{l}66.05^{\circ} \\
(34.82)\end{array}$ & $\begin{array}{l}136.66^{\circ} \\
(79.68)\end{array}$ & - \\
\hline High School & $\begin{array}{c}12.94 \\
(21.84)\end{array}$ & $\begin{array}{l}-118.4 \\
(81.02)\end{array}$ & - \\
\hline College & $\begin{array}{l}67.42 * \\
(30.93)\end{array}$ & $\begin{array}{c}57.44 \\
(52.49)\end{array}$ & - \\
\hline Mean Income & $\begin{array}{l}-1.82 * \\
(0.87)\end{array}$ & $\begin{array}{c}-2.2 \\
(1.93)\end{array}$ & - \\
\hline Exports to Country(ies) in Agreement & $\begin{array}{c}0.15 \\
(0.12)\end{array}$ & $\begin{array}{l}0.14 \\
(0.9)\end{array}$ & - \\
\hline Constant & $114.59^{\circ}$ & $\begin{array}{c}3.96 \\
(20.04)\end{array}$ & - \\
\hline $\mathrm{N}$ & 100 & 42 & - \\
\hline Pseudo R-squared & 0.55 & 0.58 & - \\
\hline
\end{tabular}

6320 failures and 38 successes completely determined. Pseudo R-squared of 1, low N, high number of independent variables, and logit likely resulting in model that is not able to fit. 
Colombia: Results for All States, and High and Low Inequality States Using Gini Coefficient Ranking to Measure Inequality

\begin{tabular}{|c|c|c|c|}
\hline & All & Low Inequality & High Inequality $^{64}$ \\
\hline Percent Lower Class in Favor of Agreement & $\begin{array}{l}-0.35 \\
(1.89)\end{array}$ & $\begin{array}{c}6.89 \\
(7.03)\end{array}$ & - \\
\hline $\begin{array}{l}\text { Percent Lower Middle Class in Favor of } \\
\text { Agreement }\end{array}$ & $\begin{array}{l}6.87^{\circ} \\
(4.11)\end{array}$ & $\begin{array}{l}-14.33 \\
(13.21)\end{array}$ & - \\
\hline $\begin{array}{l}\text { Percent Upper Middle Class in Favor of } \\
\text { Agreement }\end{array}$ & $\begin{array}{c}-5.4 \\
(3.38)\end{array}$ & $\begin{array}{l}3.16 \\
(8.87)\end{array}$ & - \\
\hline Percent Upper Class in Favor of Agreement & $\begin{array}{l}-2.05 \\
(1.59)\end{array}$ & $\begin{array}{c}5.55 \\
(8.12)\end{array}$ & - \\
\hline Inequality (Gini Coefficient Ranking) & $\begin{array}{l}-0.06 \\
(0.05)\end{array}$ & $\begin{array}{l}-1.33^{\circ} \\
(0.73)\end{array}$ & - \\
\hline Member of President's Party & $\begin{array}{l}-0.99 \\
(1.33)\end{array}$ & $\begin{aligned}-17.88^{\circ} \\
(9.90)\end{aligned}$ & - \\
\hline Total Contributions in Favor & $\begin{array}{l}0.38^{\circ} \\
(0.22)\end{array}$ & $\begin{array}{l}2.12^{\circ} \\
(1.27)\end{array}$ & - \\
\hline Total Contributions Against & $\begin{array}{c}-10.15 * * \\
(3.34)\end{array}$ & $\begin{array}{l}-23.96^{\circ} \\
(13.13)\end{array}$ & - \\
\hline No High School & $\begin{array}{l}58.54^{\circ} \\
(33.14)\end{array}$ & $\begin{array}{c}182.2 \\
(112.48)\end{array}$ & - \\
\hline High School & $\begin{array}{c}9.64 \\
(21.21)\end{array}$ & $\begin{array}{l}-393.12 \\
(256.01)\end{array}$ & - \\
\hline College & $\begin{array}{l}60.37^{*} \\
(29.34)\end{array}$ & $\begin{array}{l}-25.57 \\
(72.57)\end{array}$ & - \\
\hline Mean Income & $\begin{array}{l}-1.65^{\circ} \\
(0.85)\end{array}$ & $\begin{array}{c}-1 \\
(2.31)\end{array}$ & - \\
\hline Exports to Country(ies) in Agreement & $\begin{array}{c}0.15 \\
(0.12)\end{array}$ & $\begin{array}{c}1.24 \\
(1.49)\end{array}$ & - \\
\hline Constant & 91.85 & -2.39 & - \\
\hline $\mathrm{N}$ & 100 & 50 & - \\
\hline Pseudo R-squared & 0.54 & 0.66 & - \\
\hline
\end{tabular}

${ }^{64} 18$ failures and 32 successes completely determined. Pseudo R-squared of 1, low N, high number of independent variables, and logit likely resulting in model that is not able to fit. 


\begin{tabular}{|c|c|c|c|}
\hline & All & Low Inequality ${ }^{65}$ & High Inequality \\
\hline Percent Lower Class in Favor of Agreement & $\begin{array}{c}2.17 \\
(2.52)\end{array}$ & - & $\begin{array}{c}-5.34 \\
(8.84)\end{array}$ \\
\hline $\begin{array}{l}\text { Percent Lower Middle Class in Favor of } \\
\text { Agreement }\end{array}$ & $\begin{array}{c}0.53 \\
(4.47)\end{array}$ & - & $\begin{array}{c}8.06 \\
(14.34)\end{array}$ \\
\hline Percent Upper Middle Class in Favor of Agreement & $\begin{array}{c}-0.9 \\
(3.48)\end{array}$ & - & $\begin{array}{c}3.52 \\
(8.09)\end{array}$ \\
\hline Percent Upper Class in Favor of Agreement & $\begin{array}{l}-3.23 \\
(1.88)\end{array}$ & - & $\begin{array}{l}-8.99 \\
(6.19)\end{array}$ \\
\hline Inequality (Gini Coefficient) & $\begin{array}{c}31.47 \\
(46.76)\end{array}$ & - & $\begin{array}{c}-63 \\
(198.66)\end{array}$ \\
\hline Member of President's Party & $\begin{array}{c}-0.8 \\
(1.59)\end{array}$ & - & $\begin{array}{l}-2.66 \\
(2.6)\end{array}$ \\
\hline Total Contributions in Favor & $\begin{array}{c}0.45 \\
(0.29)\end{array}$ & - & $\begin{array}{c}1.42 \\
(1.01)\end{array}$ \\
\hline Total Contributions Against & $\begin{array}{l}-8.88 * \\
(3.56)\end{array}$ & - & $\begin{array}{c}-6.8 \\
(6.30)\end{array}$ \\
\hline No High School & $\begin{array}{l}-18.12 \\
(38.37)\end{array}$ & - & $\begin{array}{c}77.29 \\
(97.11)\end{array}$ \\
\hline High School & $\begin{array}{l}-18.12 \\
(22.04)\end{array}$ & - & $\begin{array}{c}28.39 \\
(43.92)\end{array}$ \\
\hline College & $\begin{array}{c}-19.7 \\
(37.45)\end{array}$ & - & $\begin{array}{c}27.79 \\
(77.33)\end{array}$ \\
\hline Mean Income & $\begin{array}{c}0.36 \\
(1.16)\end{array}$ & - & $\begin{array}{l}-0.26 \\
(3.30)\end{array}$ \\
\hline Exports to Country(ies) in Agreement & $\begin{array}{c}0.01 \\
(0.03)\end{array}$ & - & $\begin{array}{c}0.04 \\
(0.08)\end{array}$ \\
\hline Constant & $140.39^{\circ}$ & - & 272.82 \\
\hline $\mathrm{N}$ & 100 & - & 58 \\
\hline Pseudo R-squared & 0.46 & - & 0.57 \\
\hline
\end{tabular}

${ }^{65}$ Convergence not achieved, president's party was omitted from model 
Korea: Results for All States, and High and Low Inequality States Using Gini Coefficient Ranking to Measure Inequality

\begin{tabular}{|c|c|c|c|}
\hline & All & Low Inequality ${ }^{66}$ & High Inequality $^{67}$ \\
\hline Percent Lower Class in Favor of Agreement & $\begin{array}{c}2.37 \\
(2.63)\end{array}$ & - & 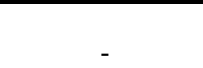 \\
\hline $\begin{array}{l}\text { Percent Lower Middle Class in Favor of } \\
\text { Agreement }\end{array}$ & $\begin{array}{l}0.18 \\
(4.6)\end{array}$ & - & - \\
\hline $\begin{array}{l}\text { Percent Upper Middle Class in Favor of } \\
\text { Agreement }\end{array}$ & $\begin{array}{l}-0.73 \\
(3.53)\end{array}$ & - & - \\
\hline Percent Upper Class in Favor of Agreement & $\begin{array}{l}-3.27^{\circ} \\
(1.92)\end{array}$ & - & - \\
\hline Inequality (Gini Coefficient Ranking) & $\begin{array}{c}0.05 \\
(0.07)\end{array}$ & - & - \\
\hline Member of President's Party & $\begin{array}{l}-0.83 \\
(1.61)\end{array}$ & - & - \\
\hline Total Contributions in Favor & $\begin{array}{l}0.46^{\circ} \\
(0.27)\end{array}$ & - & - \\
\hline Total Contributions Against & $\begin{array}{l}-8.91^{*} \\
(3.57)\end{array}$ & - & - \\
\hline No High School & $\begin{array}{l}-20.44 \\
(40.46)\end{array}$ & - & - \\
\hline High School & $\begin{array}{l}-18.99 \\
(22.68)\end{array}$ & - & - \\
\hline College & $\begin{array}{l}-20.41 \\
(38.31)\end{array}$ & - & - \\
\hline Mean Income & $\begin{array}{c}0.36 \\
(1.18)\end{array}$ & - & - \\
\hline Exports to Country(ies) in Agreement & $\begin{array}{c}0.01 \\
(0.03)\end{array}$ & - & - \\
\hline Constant & $155.19 *$ & - & - \\
\hline $\mathrm{N}$ & 100 & - & - \\
\hline Pseudo R-squared & 0.46 & - & - \\
\hline
\end{tabular}

${ }^{66}$ Convergence not achieved, president's party was omitted from model

${ }^{67}$ Convergence not achieved, president's party was omitted from model 


\section{Appendix 9: Predicted Probabilities for Individual Agreements}

CAFTA-DR: Predicted Probabilities, The Effect of Contributions in Favor, Contributions Against, and Percent in Favor by Income Category Using Gini Coefficient

\begin{tabular}{|c|c|c|c|}
\hline & All & Low Inequality & High Inequality \\
\hline \multicolumn{4}{|c|}{ Contributions in Favor } \\
\hline-0.25 std. dev. & 0.68 & 0.86 & 0.70 \\
\hline-0.1 std. dev. & 0.71 & 0.90 & 0.77 \\
\hline base & 0.72 & 0.92 & 0.81 \\
\hline+0.1 std. dev. & 0.74 & 0.93 & 0.84 \\
\hline+0.25 std. dev. & 0.76 & 0.95 & 0.88 \\
\hline \multicolumn{4}{|c|}{ Contributions Against } \\
\hline-0.25 std. dev. & 0.76 & 0.94 & 0.88 \\
\hline-0.1 std. dev. & 0.74 & 0.92 & 0.84 \\
\hline base & 0.72 & 0.92 & 0.81 \\
\hline+0.1 std. dev. & 0.71 & 0.91 & 0.77 \\
\hline+0.25 std. dev. & 0.69 & 0.89 & 0.71 \\
\hline \multicolumn{4}{|c|}{ Lower Class in Favor } \\
\hline-0.25 std. dev. & 0.84 & 0.62 & 0.98 \\
\hline-0.1 std. dev. & 0.78 & 0.83 & 0.93 \\
\hline base & 0.72 & 0.92 & 0.81 \\
\hline +0.1 std. dev. & 0.66 & 0.96 & 0.59 \\
\hline+0.25 std. dev. & 0.56 & 0.99 & 0.22 \\
\hline \multicolumn{4}{|c|}{ Lower Middle Class in Favor } \\
\hline-0.25 std. dev. & 0.73 & 1.00 & 0.11 \\
\hline-0.1 std. dev. & 0.73 & 0.99 & 0.51 \\
\hline base & 0.72 & 0.92 & 0.81 \\
\hline +0.1 std. dev. & 0.72 & 0.59 & 0.94 \\
\hline+0.25 std. dev. & 0.71 & 0.06 & 0.99 \\
\hline \multicolumn{4}{|c|}{ Upper Middle Class in Favor } \\
\hline-0.25 std. dev. & 0.65 & 0.87 & 0.25 \\
\hline-0.1 std. dev. & 0.70 & 0.90 & 0.60 \\
\hline base & 0.72 & 0.92 & 0.81 \\
\hline+0.1 std. dev. & 0.75 & 0.93 & 0.92 \\
\hline+0.25 std. dev. & 0.78 & 0.94 & 0.98 \\
\hline \multicolumn{4}{|c|}{ Upper Class in Favor } \\
\hline-0.25 std. dev. & 0.62 & 0.48 & 0.99 \\
\hline-0.1 std. dev. & 0.68 & 0.80 & 0.94 \\
\hline base & 0.72 & 0.92 & 0.81 \\
\hline +0.1 std. dev. & 0.76 & 0.97 & 0.54 \\
\hline+0.25 std. dev. & 0.81 & 0.99 & 0.15 \\
\hline
\end{tabular}

Holding all variables at their mean or mode (mode is only used for member of the President's party), adjusting variable in question. 
CAFTA-DR: Predicted Probabilities, The Effect of Contributions in Favor, Contributions Against, and Percent in Favor by Income Category Using Gini Coefficient Ranking

\begin{tabular}{|c|c|c|c|}
\hline & All & Low Inequality & High Inequality \\
\hline \multicolumn{4}{|c|}{ Contributions in Favor } \\
\hline-0.25 std. dev. & 0.69 & 0.89 & 0.74 \\
\hline-0.1 std. dev. & 0.71 & 0.92 & 0.79 \\
\hline base & 0.72 & 0.94 & 0.82 \\
\hline+0.1 std. dev. & 0.74 & 0.95 & 0.84 \\
\hline+0.25 std. dev. & 0.75 & 0.96 & 0.87 \\
\hline \multicolumn{4}{|c|}{ Contributions Against } \\
\hline-0.25 std. dev. & 0.76 & 0.95 & 0.89 \\
\hline-0.1 std. dev. & 0.74 & 0.94 & 0.85 \\
\hline base & 0.72 & 0.94 & 0.82 \\
\hline +0.1 std. dev. & 0.71 & 0.93 & 0.78 \\
\hline+0.25 std. dev. & 0.69 & 0.92 & 0.70 \\
\hline \multicolumn{4}{|c|}{ Lower Class in Favor } \\
\hline-0.25 std. dev. & 0.83 & 0.68 & 0.97 \\
\hline-0.1 std. dev. & 0.77 & 0.87 & 0.91 \\
\hline base & 0.72 & 0.94 & 0.82 \\
\hline+0.1 std. dev. & 0.67 & 0.97 & 0.67 \\
\hline+0.25 std. dev. & 0.58 & 0.99 & 0.39 \\
\hline \multicolumn{4}{|c|}{ Lower Middle Class in Favor } \\
\hline-0.25 std. dev. & 0.75 & 1.00 & 0.16 \\
\hline-0.1 std. dev. & 0.73 & 0.99 & 0.56 \\
\hline base & 0.72 & 0.94 & 0.82 \\
\hline+0.1 std. dev. & 0.71 & 0.63 & 0.94 \\
\hline+0.25 std. dev. & 0.69 & 0.06 & 0.99 \\
\hline \multicolumn{4}{|c|}{ Upper Middle Class in Favor } \\
\hline-0.25 std. dev. & 0.66 & 0.91 & 0.62 \\
\hline-0.1 std. dev. & 0.70 & 0.93 & 0.75 \\
\hline base & 0.72 & 0.94 & 0.82 \\
\hline+0.1 std. dev. & 0.75 & 0.95 & 0.87 \\
\hline+0.25 std. dev. & 0.78 & 0.96 & 0.92 \\
\hline \multicolumn{4}{|c|}{ Upper Class in Favor } \\
\hline-0.25 std. dev. & 0.61 & 0.45 & 0.97 \\
\hline-0.1 std. dev. & 0.68 & 0.82 & 0.91 \\
\hline base & 0.72 & 0.94 & 0.82 \\
\hline+0.1 std. dev. & 0.76 & 0.98 & 0.66 \\
\hline+0.25 std. dev. & 0.81 & 1.00 & 0.35 \\
\hline
\end{tabular}

Holding all variables at their mean or mode (mode is only used for member of the President's party), adjusting variable in question. 
Peru: Predicted Probabilities, The Effect of Contributions in Favor, Contributions Against, and Percent in Favor by Income Category Using Gini Coefficient

\begin{tabular}{|c|c|c|c|}
\hline & All & Low Inequality & High Inequality \\
\hline \multicolumn{4}{|c|}{ Contributions in Favor } \\
\hline-0.25 std. dev. & 0.71 & 0.76 & - \\
\hline-0.1 std. dev. & 0.71 & 0.78 & - \\
\hline base & 0.70 & 0.80 & - \\
\hline+0.1 std. dev. & 0.70 & 0.81 & - \\
\hline+0.25 std. dev. & 0.69 & 0.83 & - \\
\hline \multicolumn{4}{|c|}{ Contributions Against } \\
\hline-0.25 std. dev. & 0.73 & 0.84 & - \\
\hline-0.1 std. dev. & 0.71 & 0.82 & - \\
\hline base & 0.70 & 0.80 & - \\
\hline+0.1 std. dev. & 0.69 & 0.77 & - \\
\hline+0.25 std. dev. & 0.68 & 0.74 & - \\
\hline \multicolumn{4}{|c|}{ Lower Class in Favor } \\
\hline-0.25 std. dev. & 0.72 & 0.67 & - \\
\hline-0.1 std. dev. & 0.71 & 0.75 & - \\
\hline base & 0.70 & 0.80 & - \\
\hline+0.1 std. dev. & 0.70 & 0.83 & - \\
\hline+0.25 std. dev. & 0.68 & 0.88 & - \\
\hline \multicolumn{4}{|c|}{ Lower Middle Class in Favor } \\
\hline-0.25 std. dev. & 0.34 & 0.69 & - \\
\hline-0.1 std. dev. & 0.56 & 0.76 & - \\
\hline base & 0.70 & 0.80 & - \\
\hline+0.1 std. dev. & 0.81 & 0.83 & - \\
\hline+0.25 std. dev. & 0.92 & 0.88 & - \\
\hline \multicolumn{4}{|c|}{ Upper Middle Class in Favor } \\
\hline-0.25 std. dev. & 0.85 & 0.92 & - \\
\hline-0.1 std. dev. & 0.77 & 0.86 & - \\
\hline base & 0.70 & 0.80 & - \\
\hline +0.1 std. dev. & 0.63 & 0.72 & - \\
\hline+0.25 std. dev. & 0.51 & 0.57 & - \\
\hline \multicolumn{4}{|c|}{ Upper Class in Favor } \\
\hline-0.25 std. dev. & 0.79 & 0.81 & - \\
\hline-0.1 std. dev. & 0.74 & 0.80 & - \\
\hline base & 0.70 & 0.80 & - \\
\hline +0.1 std. dev. & 0.66 & 0.79 & - \\
\hline+0.25 std. dev. & 0.60 & 0.78 & - \\
\hline
\end{tabular}

Holding all variables at their mean or mode (mode is only used for member of the President's party), adjusting variable in question. 
Peru: Predicted Probabilities, The Effect of Contributions in Favor, Contributions Against, and Percent in Favor by Income Category Using Gini Coefficient Ranking

\begin{tabular}{|c|c|c|c|}
\hline & All & Low Inequality & High Inequality \\
\hline \multicolumn{4}{|c|}{ Contributions in Favor } \\
\hline-0.25 std. dev. & 0.72 & 0.82 & - \\
\hline-0.1 std. dev. & 0.71 & 0.84 & - \\
\hline base & 0.70 & 0.86 & - \\
\hline+0.1 std. dev. & 0.70 & 0.87 & - \\
\hline+0.25 std. dev. & 0.69 & 0.89 & - \\
\hline \multicolumn{4}{|c|}{ Contributions Against } \\
\hline-0.25 std. dev. & 0.73 & 0.90 & - \\
\hline-0.1 std. dev. & 0.71 & 0.88 & - \\
\hline base & 0.70 & 0.86 & - \\
\hline+0.1 std. dev. & 0.69 & 0.83 & - \\
\hline+0.25 std. dev. & 0.68 & 0.80 & - \\
\hline \multicolumn{4}{|c|}{ Lower Class in Favor } \\
\hline-0.25 std. dev. & 0.73 & 0.74 & - \\
\hline-0.1 std. dev. & 0.71 & 0.82 & - \\
\hline base & 0.70 & 0.86 & - \\
\hline+0.1 std. dev. & 0.69 & 0.89 & - \\
\hline+0.25 std. dev. & 0.68 & 0.93 & - \\
\hline \multicolumn{4}{|c|}{ Lower Middle Class in Favor } \\
\hline-0.25 std. dev. & 0.34 & 0.67 & - \\
\hline-0.1 std. dev. & 0.57 & 0.80 & - \\
\hline base & 0.70 & 0.86 & - \\
\hline+0.1 std. dev. & 0.81 & 0.90 & - \\
\hline+0.25 std. dev. & 0.92 & 0.95 & - \\
\hline \multicolumn{4}{|c|}{ Upper Middle Class in Favor } \\
\hline-0.25 std. dev. & 0.85 & 0.97 & - \\
\hline-0.1 std. dev. & 0.77 & 0.93 & - \\
\hline base & 0.70 & 0.86 & - \\
\hline+0.1 std. dev. & 0.63 & 0.74 & - \\
\hline+0.25 std. dev. & 0.51 & 0.50 & - \\
\hline \multicolumn{4}{|c|}{ Upper Class in Favor } \\
\hline-0.25 std. dev. & 0.79 & 0.86 & - \\
\hline-0.1 std. dev. & 0.74 & 0.86 & - \\
\hline base & 0.70 & 0.86 & - \\
\hline +0.1 std. dev. & 0.67 & 0.86 & - \\
\hline+0.25 std. dev. & 0.61 & 0.86 & - \\
\hline
\end{tabular}

Holding all variables at their mean or mode (mode is only used for member of the President's party), adjusting variable in question. 
Colombia: Predicted Probabilities, The Effect of Contributions in Favor, Contributions Against, and Percent in Favor by Income Category Using Gini Coefficient

\begin{tabular}{|c|c|c|c|}
\hline & All & Low Inequality & High Inequality \\
\hline \multicolumn{4}{|c|}{ Contributions in Favor } \\
\hline-0.25 std. dev. & 0.75 & 0.77 & - \\
\hline-0.1 std. dev. & 0.78 & 0.81 & - \\
\hline base & 0.80 & 0.84 & - \\
\hline+0.1 std. dev. & 0.82 & 0.86 & - \\
\hline+0.25 std. dev. & 0.85 & 0.89 & - \\
\hline \multicolumn{4}{|c|}{ Contributions Against } \\
\hline-0.25 std. dev. & 0.88 & 0.90 & - \\
\hline-0.1 std. dev. & 0.84 & 0.86 & - \\
\hline base & 0.80 & 0.84 & - \\
\hline+0.1 std. dev. & 0.76 & 0.81 & - \\
\hline+0.25 std. dev. & 0.69 & 0.75 & - \\
\hline \multicolumn{4}{|c|}{ Lower Class in Favor } \\
\hline-0.25 std. dev. & 0.82 & 0.24 & - \\
\hline-0.1 std. dev. & 0.81 & 0.63 & - \\
\hline base & 0.80 & 0.84 & - \\
\hline+0.1 std. dev. & 0.80 & 0.94 & - \\
\hline+0.25 std. dev. & 0.79 & 0.99 & - \\
\hline \multicolumn{4}{|c|}{ Lower Middle Class in Favor } \\
\hline-0.25 std. dev. & 0.27 & 0.98 & - \\
\hline-0.1 std. dev. & 0.61 & 0.92 & - \\
\hline base & 0.80 & 0.84 & - \\
\hline+0.1 std. dev. & 0.91 & 0.69 & - \\
\hline+0.25 std. dev. & 0.98 & 0.38 & - \\
\hline \multicolumn{4}{|c|}{ Upper Middle Class in Favor } \\
\hline-0.25 std. dev. & 0.96 & 0.85 & - \\
\hline-0.1 std. dev. & 0.89 & 0.84 & - \\
\hline base & 0.80 & 0.84 & - \\
\hline+0.1 std. dev. & 0.68 & 0.83 & - \\
\hline+0.25 std. dev. & 0.43 & 0.82 & - \\
\hline \multicolumn{4}{|c|}{ Upper Class in Favor } \\
\hline-0.25 std. dev. & 0.87 & 0.90 & - \\
\hline-0.1 std. dev. & 0.83 & 0.87 & - \\
\hline base & 0.80 & 0.84 & - \\
\hline +0.1 std. dev. & 0.77 & 0.80 & - \\
\hline+0.25 std. dev. & 0.71 & 0.74 & - \\
\hline
\end{tabular}

Holding all variables at their mean or mode (mode is only used for member of the President's party), adjusting variable in question. 
Colombia: Predicted Probabilities, The Effect of Contributions in Favor, Contributions Against, and Percent in Favor by Income Category Using Gini Coefficient Ranking

\begin{tabular}{|c|c|c|c|}
\hline & All & Low Inequality & High Inequality \\
\hline \multicolumn{4}{|c|}{ Contributions in Favor } \\
\hline-0.25 std. dev. & 0.74 & 0.87 & - \\
\hline-0.1 std. dev. & 0.77 & 0.93 & - \\
\hline base & 0.79 & 0.96 & - \\
\hline +0.1 std. dev. & 0.81 & 0.97 & - \\
\hline+0.25 std. dev. & 0.83 & 0.99 & - \\
\hline \multicolumn{4}{|c|}{ Contributions Against } \\
\hline-0.25 std. dev. & 0.87 & 0.99 & - \\
\hline-0.1 std. dev. & 0.82 & 0.97 & - \\
\hline base & 0.79 & 0.96 & - \\
\hline +0.1 std. dev. & 0.75 & 0.92 & - \\
\hline+0.25 std. dev. & 0.68 & 0.83 & - \\
\hline \multicolumn{4}{|c|}{ Lower Class in Favor } \\
\hline-0.25 std. dev. & 0.81 & 0.72 & - \\
\hline-0.1 std. dev. & 0.80 & 0.90 & - \\
\hline base & 0.79 & 0.96 & - \\
\hline+0.1 std. dev & 0.78 & 0.98 & - \\
\hline+0.25 std. dev. & 0.77 & 0.99 & - \\
\hline \multicolumn{4}{|c|}{ Lower Middle Class in Favor } \\
\hline-0.25 std. dev. & 0.26 & 1.00 & - \\
\hline-0.1 std. dev. & 0.59 & 0.99 & - \\
\hline base & 0.79 & 0.96 & - \\
\hline+0.1 std. dev. & 0.91 & 0.80 & - \\
\hline+0.25 std. dev. & 0.98 & 0.24 & - \\
\hline \multicolumn{4}{|c|}{ Upper Middle Class in Favor } \\
\hline-0.25 std. dev. & 0.95 & 0.90 & - \\
\hline-0.1 std. dev. & 0.88 & 0.94 & - \\
\hline base & 0.79 & 0.96 & - \\
\hline+0.1 std. dev. & 0.66 & 0.97 & - \\
\hline+0.25 std. dev. & 0.41 & 0.98 & - \\
\hline \multicolumn{4}{|c|}{ Upper Class in Favor } \\
\hline-0.25 std. dev. & 0.86 & 0.86 & - \\
\hline-0.1 std. dev. & 0.82 & 0.93 & - \\
\hline base & 0.79 & 0.96 & - \\
\hline+0.1 std. dev. & 0.75 & 0.97 & - \\
\hline+0.25 std. dev. & 0.69 & 0.99 & - \\
\hline
\end{tabular}

Holding all variables at their mean or mode (mode is only used for member of the President's party), adjusting variable in question. 
Korea: Predicted Probabilities, The Effect of Contributions in Favor, Contributions Against, and Percent in Favor by Income Category Using Gini Coefficient

\begin{tabular}{|c|c|c|c|}
\hline & All & Low Inequality & High Inequality \\
\hline \multicolumn{4}{|c|}{ Contributions in Favor } \\
\hline-0.25 std. dev. & 0.93 & - & 0.99 \\
\hline-0.1 std. dev. & 0.94 & - & 0.99 \\
\hline base & 0.94 & - & 1.00 \\
\hline+0.1 std. dev. & 0.95 & - & 1.00 \\
\hline+0.25 std. dev. & 0.96 & - & 1.00 \\
\hline \multicolumn{4}{|c|}{ Contributions Against } \\
\hline-0.25 std. dev. & 0.97 & - & 1.00 \\
\hline-0.1 std. dev. & 0.95 & - & 1.00 \\
\hline base & 0.94 & - & 1.00 \\
\hline+0.1 std. dev. & 0.93 & - & 1.00 \\
\hline+0.25 std. dev. & 0.91 & - & 0.99 \\
\hline \multicolumn{4}{|c|}{ Lower Class in Favor } \\
\hline-0.25 std. dev. & 0.88 & - & 1.00 \\
\hline-0.1 std. dev. & 0.92 & - & 1.00 \\
\hline base & 0.94 & - & 1.00 \\
\hline+0.1 std. dev. & 0.96 & - & 0.99 \\
\hline+0.25 std. dev. & 0.97 & - & 0.97 \\
\hline \multicolumn{4}{|c|}{ Lower Middle Class in Favor } \\
\hline-0.25 std. dev. & 0.93 & - & 0.92 \\
\hline-0.1 std. dev. & 0.94 & - & 0.99 \\
\hline base & 0.94 & - & 1.00 \\
\hline+0.1 std. dev. & 0.95 & - & 1.00 \\
\hline+0.25 std. dev. & 0.95 & - & 1.00 \\
\hline \multicolumn{4}{|c|}{ Upper Middle Class in Favor } \\
\hline-0.25 std. dev. & 0.96 & - & 0.99 \\
\hline-0.1 std. dev. & 0.95 & - & 0.99 \\
\hline base & 0.94 & - & 1.00 \\
\hline+0.1 std. dev. & 0.94 & - & 1.00 \\
\hline+0.25 std. dev. & 0.93 & - & 1.00 \\
\hline \multicolumn{4}{|c|}{ Upper Class in Favor } \\
\hline-0.25 std. dev. & 0.97 & - & 1.00 \\
\hline-0.1 std. dev. & 0.96 & - & 1.00 \\
\hline base & 0.94 & - & 1.00 \\
\hline +0.1 std. dev. & 0.92 & - & 0.99 \\
\hline+0.25 std. dev. & 0.88 & - & 0.96 \\
\hline
\end{tabular}

Holding all variables at their mean or mode (mode is only used for member of the President's party), adjusting variable in question. 
Korea: Predicted Probabilities, The Effect of Contributions in Favor, Contributions Against, and Percent in Favor by Income Category Using Gini Coefficient Ranking

\begin{tabular}{|c|c|c|c|}
\hline & All & Low Inequality & High Inequality \\
\hline \multicolumn{4}{|c|}{ Contributions in Favor } \\
\hline-0.25 std. dev. & 0.93 & - & - \\
\hline-0.1 std. dev. & 0.94 & - & - \\
\hline base & 0.95 & - & - \\
\hline+0.1 std. dev. & 0.95 & - & - \\
\hline+0.25 std. dev. & 0.96 & - & - \\
\hline \multicolumn{4}{|c|}{ Contributions Against } \\
\hline-0.25 std. dev. & 0.97 & - & - \\
\hline-0.1 std. dev. & 0.96 & - & - \\
\hline base & 0.95 & - & - \\
\hline +0.1 std. dev. & 0.93 & - & - \\
\hline+0.25 std. dev. & 0.91 & - & - \\
\hline \multicolumn{4}{|c|}{ Lower Class in Favor } \\
\hline-0.25 std. dev. & 0.88 & - & - \\
\hline-0.1 std. dev. & 0.92 & - & - \\
\hline base & 0.95 & - & - \\
\hline +0.1 std. dev. & 0.96 & - & - \\
\hline+0.25 std. dev. & 0.98 & - & - \\
\hline \multicolumn{4}{|c|}{ Lower Middle Class in Favor } \\
\hline-0.25 std. dev. & 0.94 & - & - \\
\hline-0.1 std. dev. & 0.94 & - & - \\
\hline base & 0.95 & - & - \\
\hline +0.1 std. dev. & 0.95 & - & - \\
\hline+0.25 std. dev. & 0.95 & - & - \\
\hline \multicolumn{4}{|c|}{ Upper Middle Class in Favor } \\
\hline-0.25 std. dev. & 0.96 & - & - \\
\hline-0.1 std. dev. & 0.95 & - & - \\
\hline base & 0.95 & - & - \\
\hline +0.1 std. dev. & 0.94 & - & - \\
\hline+0.25 std. dev. & 0.93 & - & - \\
\hline \multicolumn{4}{|c|}{ Upper Class in Favor } \\
\hline-0.25 std. dev. & 0.97 & - & - \\
\hline-0.1 std. dev. & 0.96 & - & - \\
\hline base & 0.95 & - & - \\
\hline +0.1 std. dev. & 0.93 & - & - \\
\hline+0.25 std. dev. & 0.89 & - & - \\
\hline
\end{tabular}

Holding all variables at their mean or mode (mode is only used for member of the President's party), adjusting variable in question. 


\section{Chapter 5}

\section{The Influence of the Public and Interest Groups on Latin American Trade Openness}

While Chapter IV allowed me to examine how my theory applied in the context of one country, the US, the Latin American case allows me to examine how my theory applies across a group of countries. As discussed in Chapters II \& III, the main advantage of the Latin American case is it allows me to examine my theory in the context of states that, while having significant variations in their interest group systems, are still largely transitioning from informal interest group systems to formal interest group systems. My theory also allows me to consider states that are less economically developed than the US, but still democratic. This is done with the expectation that my theory will apply across all democratic states.

To test my theory in the Latin American context I examine overall levels of trade, using public opinion on trade to measure public support, and using the public's perception of the power of interest groups and the power of unions as a measure of interest group influence.

Additionally, because of the relatively high level of corruption in Latin America, corruption in a state is used as a proxy for influence by business interest groups. The use of the Latinobarometer survey allows me to examine the individual level assumptions of my theory in terms of who participates as inequality changes. The regression findings do not entirely support my theory, but similar to the findings in the American chapter, they do provide evidence that it may be the middle class who is able to have the greatest influence over trade policy. The results for the individual level of my theory point to the possibility that those in the lower class become more politically active in some areas when inequality increases, however, going back to the state level results in the previous chapter, it does not seem that this increased activity leads to increased influence over trade policy. The results for the individual level also point to the public seeing 
business interest groups as more influential and unions as less influential as inequality increases, providing some support for my theory.

\section{Trade and Inequality in Latin America}

As discussed in Chapter III, Latin American states were relatively isolated in terms of trade up until the 1990s, then these states began rapidly joining trade agreements, and along with other neo-liberal reforms, many Latin American countries began to experience rapid economic growth (Hogenboom and Jilberto 2012). However, inequality, already high in Latin America increased even more. Initially, with this openness, the relatively poor were given more job opportunities in low skilled manufacturing work; yet with trade openness also came more job competition for Latin American workers as other countries that were lower income than Latin American countries began to open up and their low-skilled workers began to compete with low skilled workers in Latin America (Wood 1997). These low skilled workers in other countries were able to outcompete Latin American low-skilled workers in terms of wages and therefore increased competition pushed down the wages of low-skilled Latin American workers.

As Wood (1997) explains, at the same time low-skilled workers in Latin America were facing competition from other low-skilled workers elsewhere in the world, more educated higher-skilled workers in Latin America were able to take advantage of new technologies that came with openness to increase their incomes, increasing inequality. Latin American countries, as middle-income countries, were neither able to compete on low-wage workers or on highskilled workers. Low-skilled workers in Latin America do not offer the lowest wages, therefore companies looking for low-skilled workers are likely to go elsewhere, where wages are cheaper. Therefore, I expect the lower the skill level of workers in Latin America, the less they will prefer openness. This seems to be the case. Figure 1 shows the overall support for regional trade 
openness and the support for trade openness among those in Latin America in five different SES categories, as well as averaged across countries. ${ }^{68}$ As SES declines support for regional trade openness and trade openness decreases.

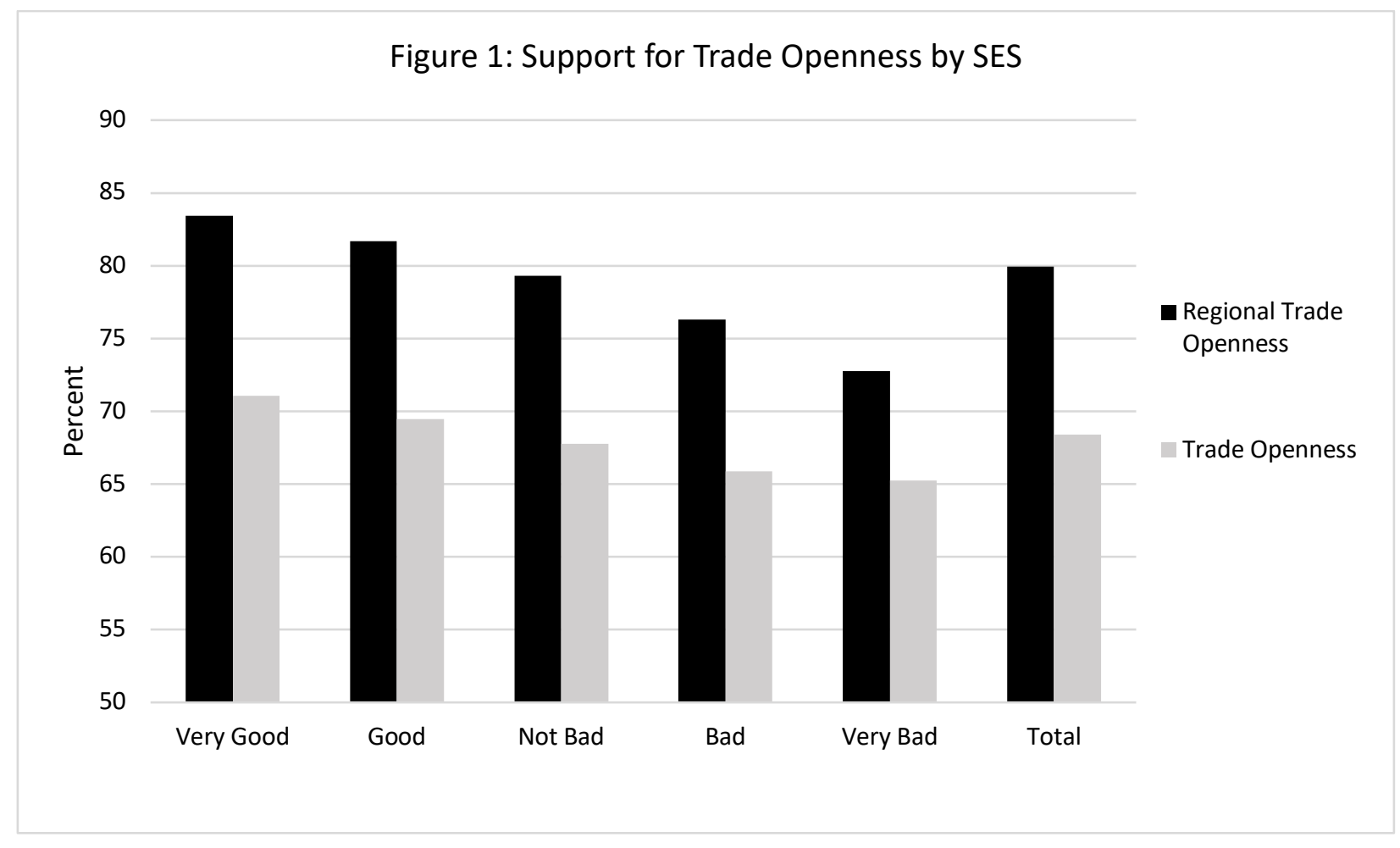

\section{Hypotheses}

The same theory is being applied to the Latin American context, therefore the hypotheses in this chapter are similar to the ones in Chapter IV. While the forces affecting trade policy are expected to be similar in the Latin American context, because of data limitations, which will be discussed below, changes in inequality cannot be directly tested at the country level, although they are examined with individual level data. However, the broader assertation of my theory regarding who has influence over policy can be tested at the state level. Overall, I argue that, as

\footnotetext{
${ }^{68}$ The Latinobarometer was used to construct the measure of regional trade openness and trade openness. This measure is the percent of respondents in each SES category, averaged across several years, who supported regional trade openness/trade openness. The years and questions used to construct the measure of trade openness and the measure of regional trade openness are in Appendix 1 and Appendix 2, respectively. SES was also measured using the Latinobarometer which asks surveyors to write down respondents' SES by observing the respondents home.
} 
long as there is some inequality in an area, those at the top will have the greatest influence over policy.

Hypothesis 1: The higher a group's income, the more the level of trade openness will reflect their trade preferences.

I argue when there is higher inequality business interest groups will have greater influence while mass based interest groups will have less influence. Therefore, because Latin American countries have a relatively high level of inequality, I expect in Latin America, business interest groups will have more influence over policy than mass based interest groups.

Hypothesis 2: Business interest groups will have greater influence over trade openness than mass based interest groups.

\section{Data and Methods}

This section is in two parts; first I examine the country level, and then I examine the individual level assumptions.

In the first section, a total of 18 Latin American countries are included in the analysis and examined from 1995-2015. The years of analysis are limited because data from the Latinobarometer is being used to measure public opinion on trade policy, this limits the years as well as the number of countries that can be examined. ${ }^{69}$ Cross-sectional time series regression is used to test the hypotheses.

\footnotetext{
${ }^{69}$ The countries included in the Latinobarometer are Argentina, Bolivia, Brazil, Chile, Colombia, Costa Rica, Dominican Republic, Ecuador, El Salvador, Guatemala, Honduras, Mexico, Nicaragua, Panama, Paraguay, Peru, Uruguay, and Venezuela. Only Argentina, Brazil, Chile, Mexico, Paraguay, Peru, Uruguay, and Venezuela were included in 1995. The Latinobarometer has taken place every year since 1995, except for 1999 and 2014, while a joint Latinobarometer took place for 2012-2013. No questions regarding trade were asked in 2011-2013. The Latinobarometer is available up to 2016.
} 


\section{Dependent Variable: Trade Openness}

In order to examine the impact of the public and interest groups on a country's overall level of trade openness a country's imports and exports are summed and divided by GDP. Data on imports, exports, and GDP come from the World Bank World Development Indicators.

Because there is the expectation that it takes time for democratic governments to respond to pressures to change trade policy, the independent variables are lagged a year. By measuring both imports and exports this measure of trade openness has the advantage of capturing all trade activity in a country. Measures such as the number of agreements a country is in do not capture the overall level of trade a country engages in. A state could be party to several trade agreements, but these agreements might be with states that have relatively small economies, making the overall impact of trade less than if a state is only in a few relatively large trade agreements. Table 1 has summary statistics on all variables.

Table 1: Summary Statistics All Variables

\begin{tabular}{lllll}
\hline & Mean & Std. Dev. & Min. & Max. \\
\hline Trade Openness & 65.66 & 29.92 & 15.64 & 165.34 \\
\% For Openness Very Good SES & 5.73 & 3.33 & 0.75 & 25.42 \\
\% For Openness Good SES & 22.90 & 8.05 & 4.75 & 50.67 \\
\% For Openness Not Bad SES & 26.35 & 8.45 & 3.33 & 44.4 \\
\% For Openness Bad SES & 7.75 & 4.19 & 0.67 & 28.90 \\
\% For Openness Very Bad SES & 1.80 & 2.02 & 0.08 & 15.09 \\
Inequality (Gini) & 46.88 & 3.95 & 36.92 & 55.22 \\
Inequality (Gini using SES) & 14.28 & 2.58 & 8.46 & 24.36 \\
Corruption * Inequality (Gini) & 299.88 & 72.05 & 96.33 & 438.24 \\
Corruption * Inequality (Gini using SES) & 92.43 & 27.29 & 27.63 & 168.05 \\
Corruption & 6.41 & 1.39 & 2.06 & 8.5 \\
Union Power & 11.34 & 6.59 & 1.71 & 33.08 \\
Business Power & 58.82 & 12.55 & 18.7 & 87 \\
GDP per capita (thousands) & 5.92 & 3.55 & 1.12 & 14.69 \\
Democracy & 7.62 & 1.58 & 5 & 10 \\
Right Regime & 0.32 & 0.47 & 0 & 1 \\
Left Regime & 0.33 & 0.47 & 0 & 1 \\
\hline
\end{tabular}




\section{Independent Variables}

\section{Public Opinion on Trade}

To measure public opinion on trade policy in Latin America, data from the Latinobarometer is used. The Latinobarometer provides a wealth of Latin American public opinion data regarding trade. The drawback of using the Latinobarometer is that the same questions regarding trade were not asked each year, with questions ranging from asking about trade agreements in general, to asking about specific trade agreements.

To measure trade preferences, an index variable measuring preferences for trade openness was created. This variable is the percentage of respondents in favor of trade or think trade is beneficial. To construct this measure questions regarding general trade policy from the Latinobarometer are used, the questions used are in Appendix 1. Although the questions vary, they all assess the same concept, if someone is for or against trade. Questions about trade were asked in the Latinobarometer from 1995 to 2015 . The expectation is that the more the public is in favor of trade the more likely a state will be to enter an agreement.

\section{Preferences by Income}

In order to test the first and second hypotheses public preferences by income are needed. The Latinobarometer does not directly ask individuals about their income but does ask the interviewer to assess the respondent's dwelling in order to determine their socioeconomic level. There are five levels, ranging from very bad to very good. This same measure of socioeconomic status is used in all years in which the Latinobarometer takes place. While this measure is an imperfect measure because individuals can live above or below their means, there are two advantages of this measure. First, it eliminates the issue of respondents misreporting their incomes, and second, this measure captures overall wealth, not just income. Individuals with 
more wealth, either from income or from other sources, are expected to be the ones who are able to have the greatest amount of influence.

The percentage in each income group, as measured by SES, in favor of trade openness, is used. The expectation is that the preferences of those in the higher income groups will have a greater influence over trade policy formation than the preferences of those in lower income groups. Inequality

The Gini index is used as the measure of inequality. The Gini index is simply the Gini coefficient reported as a percent instead of a proportion and is a measure of income inequality; the higher the Gini index the greater the inequality. The Standardized Income Inequality Database from Solt (2016) estimates missing Gini Index data, providing a greater number of countries' years, therefore these data are used. Gini is used because it measures overall income inequality in an economy, and it is these changes in overall inequality that are expected to affect the influence the public and interest groups have over trade policy. The expectation is, as inequality increases the effect public opinion has on trade agreement outcomes will decrease.

While the Gini index does have the advantage of being widely available and of providing a measure of the overall level of inequality in an area, the main disadvantage is that the Gini index only measures income inequality. Since the Latinobarometer asks the surveyor to assess a respondent's overall surroundings and then gauge their overall socioeconomic level this can be used to construct a measure of inequality in a state. The main advantage of this measure is by observing a person's surroundings the surveyor is not just relying on a person's stated income to assess how well off they are. For example, a person might have received a large inheritance and therefore be able to live well above what their earned income is, using observed SES allows for 
creating an inequality measure based on income as well as wealth. The disadvantage of constructing a measure from observed SES is a person could be living above or below their means, and therefore observed SES does not completely capture a person's wealth and income.

The measure of inequality using observed SES from the Latinobarometer is constructed in the same way as the Gini index, but instead of using income data for a population, I use SES data. To construct this measure of inequality, first a hypothetical population of 10,000 was created using the percent of respondents in each of the five SES categories reported in the Latinobarometer. These categories are very bad, bad, not bad, good, and very good. Each of these categories was assigned a number 1 through 5 as follows, very bad 1, bad 2, not bad 3, good 4, very good 5. Then the hypothetical population was created to be proportional to the number of respondents in each category in a given year. For example, if 30 percent of the respondents were in the very bad category, 3,000 members of the population were given a 1, 20 percent in the bad category, 2,000 members a 2, and so on. This population was then used to calculate the Gini index for each country for each year using the "ineq" package in the statistical program $R$.

Overall, the correlation between the Gini index and Gini constructed using SES is 0.1394, showing there is a relationship between the two, but only a slight one. The mean for the Gini index constructed using SES is much lower than the mean for the Gini index, 14.28 versus 46.88 . This lower overall level of Gini is likely because of the lack of extremes that the limited SES categories capture. The SES categories do not capture those who are extremely well off or those who are in extreme poverty, these people are lumped in with the very good and very bad categories, respectively. However, the ranges of each of these measures are similar to one another. The range for Gini using SES is 15.9 , while the range for the Gini index is 18.3. The 
Gini index does have a slightly higher standard deviation, at 3.95 compared to 2.58 . Overall, these statistics show there is reason to expect somewhat, but not entirely different results when Gini using SES is used to measure inequality instead of the Gini index.

\section{Interest Group Influence}

Measuring interest group activity in Latin America is difficult because of the variation of the types of interest groups in the region. While there is a fair amount of corruption in Latin America, there are also more formalized interest group systems.

Corruption is widespread across Latin America, with corruption remaining high despite liberalization, therefore there are open avenues of influence for those with resources (Morris 2008). Corruption not only allows for more access for those with resources, but when corruption is institutionalized, as in Latin America, there is little chance of negative repercussions from engaging in corruption (Manzetti and Blake 1996). Thomas and Klimovich (2014) write that in

\section{Latin America,}

political corruption is often very overt. Corruption has been endemic to political life, stemming from the dominance of personalism and informal political institutions in the political culture, producing clientelism and other forms of particularism, as opposed to formal political institutional relationships. (Thomas and Klimovich 2014, 172)

Therefore, to a large extent, interest groups in Latin America are largely informal (Hogenboom and Jilberto 2012; Thomas and Klimovich 2014); while there are some active formal interest groups in Latin America, these groups often operate alongside or in conjunction with informal interest groups (Bull 2014).

Informal interest groups work to influence policy just as formal groups do, but these groups are not registered, and their activities are not formally reported. The term informal interest group is used broadly to capture anyone trying to influence the government outside of a formal process. For example, the representative of a business meeting with a politician, or an 
unregistered community group inviting a politician to one of their functions. As businesses have grown in Latin America alongside liberalization, so has their government influence, and corruption remains a central part of Latin American politics (Hogenboom and Jilberto 2012). There are close ties between big business and political elites, with politicians fighting against external forces pressuring them for reforms because of their desire to maintain the current system of patronage and clientelism (Hogenboom and Jilberto 2012).

In many cases, the neo-liberal reforms in Latin America took away state resources that politicians could use for personal gain, but corruption remained because businesses grew, as did bribes and kickbacks to politicians from them (Manzetti and Blake 1996). Large businesses and transnational businesses in Latin America have been able to maintain a strong position in Latin American politics because of their concentration of wealth (Hogenboom and Jilberto 2012). This does not mean more formal interest group systems do not exist. Thomas and Klimovich (2014) argue, while corruption is a common theme across Latin American states, Latin America should not be treated as monolith when it comes to interest groups. Latin American countries have made efforts to eliminate corruption with varying degrees of success (dos Santos and da Costa 2012). Countries fall on a spectrum between two different types of interest group systems. On one end there is the integrated system, where there is a diverse set of interest groups that compete for influence and lobbying activities are largely transparent, and on the other there is the bifurcated interest group system, where a small group of elites have access, while groups in the mass public largely do not have access to politicians, lobbying is not transparent, and corruption is the norm (Thomas and Klimovich 2014).

That Latin American countries have no one set type of interest group system gives the benefit of being able to test my theory across multiple systems, but also provides the challenge of 
how to measure interest group activity when there is both formal and informal activity. Interest group activity is measured in three ways, first because corruption is still the norm in several Latin American countries, corruption is used as a measure of interest group activity. As previously discussed, it is largely the elite and not the mass public who have access when there is corruption, therefore corruption is expected to be a better measure of the influence elites, and in turn, influence businesses have on policy. However, corruption does not capture formal interest group activities and is not expected to capture a large amount of mass-based interest group activities. Therefore, in addition to using corruption as a measure of interest group activity, measures of the public perception of the power of unions and of businesses are used.

For the measure of corruption, as a measure of informal interest group influence, the corruption perception index (CPI) from Transparency International is used. This index measures the perceived level of corruption in a country. Ideally, a direct measure of informal interest group influence would be used, however, because of the informal nature of these groups, corruption is used as a proxy measure. The index is available from 1995-2011 and ranges from 0-10, while from 2012-2014 the index ranges from 0-100. ${ }^{70}$ As a country's CPI score increases, the level of perceived corruption in a country decreases. The expectation is, when there is more inequality, corruption will have a greater effect on a country's willingness to join a trade agreement, thus the index is subtracted from 10 to get the inverse, so a higher score means more corruption. This is done because corruption will be interacted with inequality; more inequality is expected to mean more influence from interest groups and less influence from the public, just as more corruption is expected to mean more influence from interest groups and less influence from the public.

Inequality and corruption are run as an interaction term because of the influence inequality is

\footnotetext{
${ }^{70}$ From 2012-2014 the index is divided by ten to make the scales compatible.
} 
expected to have on corruption. The models will also be run including corruption and inequality as separate variables.

To measure the influence of unions and businesses I use public opinion on whether or not the public believes unions and businesses have power. The Latinobarometer asks respondents which groups they believe have the most power in their country, allowing respondents to list up to three groups. The possible groups to choose from include businesses as well as unions. The Latinobarometer does not directly ask about business interest groups, therefore the power of businesses will be used as a proxy for the power of business interest groups, with the expectation that much of the power of businesses is related to their use of interest groups to promote their interest. The percentage of respondents in a country who responded that unions were one of the three most power groups is used as the measure of union power. When unions are more powerful countries are expected to have less trade openness. The correlation between corruption and the percent of people mentioning unions as one of the most powerful groups is -0.15 , showing union power likely decreases when there is greater corruption, and that corruption is likely not an accurate measure of union power in a country.

The question on powerful groups asks about several different types of businesses. If a respondent responded that any of these groups were one of the three most powerful groups in a country they were coded as saying businesses are powerful; this was used to construct a variable of the percentage of people by country who believe businesses are powerful. I expect that the more powerful businesses are the more trade openness there will be. The types of businesses asked about are large companies, medium-sized companies, banks, and transnational companies. The correlation between corruption and the percentage of respondents mentioning businesses as one of the most powerful groups is 0.27 , showing it is likely business power increases with 
corruption, and that corruption is a more accurate measure of business power than of union power. The Latinobarometer does not ask about all types of businesses in all years, therefore several different measures of business power were constructed. The results of these regressions are in Appendixes 3-8; these results are similar to the ones when all types of businesses are included, these are the results reported in the main text. ${ }^{71}$

The major advantage of using public opinion to measure interest group influence is that it allows for assessing the power of unions and businesses across different interest group systems. By not relying on measures such as the reporting of campaign contributions, which would not be accurate when there is corruption, it allows for the public to assess how much power they believe groups have. Additionally, this measure can be applied effectively across systems because it is assessing the power of groups, not how they achieved this power; they could have achieved power through legitimate activities, such as campaign contributions that are reported, or they could gain influence through corruption. Another advantage of this measure is it is able to capture various forms of influence; a group could be powerful because they are really effective at organizing protests and running ads, or they could be powerful because they give contributions to politicians. These activities are all captured in this measure.

The main limitation of these measures is that the Latinobarometer does not ask people every year what they believe the most powerful groups in the country are. ${ }^{72}$ This lowers the $\mathrm{N}$ compared with when corruption is used as a measure.

\footnotetext{
${ }^{71}$ Large companies were asked about in 1995, 1996, 1997, 1998, 2000, 2001, 2003, 2004, 2005, 2006, and 2010; medium sized companies were asked about in 1995, 1996, and 1997; banks were asked about in 1995, 1996, 1997, 1998, 2000, 2001, 2003, 2004, 2005, 2006, and 2010; transnational companies were asked about in 1995, 1996, 1997, 1998, 2000, and 2001.

72 The Latinobarometer asked respondents who they believed are the most powerful groups in 1995, 1996, 1997, 1998, 2000, 2001, 2003, 2004, 2005, 2006, and 2010.
} 


\section{Controls $^{73}$}

Because my theory only applies to democracies and there are different levels of democracy within Latin America, the level of democracy in a state needs to be controlled for. Polity democracy scores are used to control for the level of democracy in a state. Polity democracy scores are a measure of the level of democracy in a country and range from 0 to 10 , with 10 being a fully democratic state. States are only included for years in which they scored a five or above. Mexico scores below a five in 1995 and 1996, while Venezuela scores below a five after 2009, all other states score a five or above for all years.

Those with higher incomes are more likely to be the owners of capital and therefore should be more likely to favor free trade. As a proxy for income, GDP per capita (constant 2005 US dollars) is used, with data coming from the World Bank World Development Indicators. Due to the fact that GDP is a measure of all the economic activity in a country, countries with higher GDP per capita should have a higher mean income.

Data on regime type comes from the Inter-American Development Bank Database of Political Institutions (DPI). The DPI of political institutions codes ruling parties as left, right, or centrist based on their orientation towards economic issues. Since the measure is based on economic issues it is also ideal for controlling how likely a governing party is to be to enter an agreement. The DPI coding of the governing party is 1 for right parties, 2 for centrist parties, and 3 for leftist parties. Following Reeves et al. (2014) the DPI was used to create three dichotomous variables, one for countries ruled by right parties, one for centrist, and one for leftist. Centrist will be used as the baseline category. I expect states with left leaning regimes,

\footnotetext{
${ }^{73}$ While a country being a member of the World Trade Organization will likely impact their level of trade openness there is little variation in WTO membership among the countries in the analysis. 16 of the 18 countries joined the WTO in 1995, the other two, Ecuador and Panama, joined in 1996 and 1997, respectively (WTO 2018).
} 
those that have a left leaning political party in control of the government, will be more protectionist, while those with right leaning regimes, those that have a right leaning political party in control, will be less protectionist. ${ }^{74}$

\section{Results}

Table 2: Results with Inequality and Corruption as an Interaction Term, and Separate

\begin{tabular}{|c|c|c|c|c|}
\hline & $\begin{array}{c}\text { Corruption * } \\
\text { Inequality (Gini) }\end{array}$ & $\begin{array}{c}\text { Corruption * } \\
\text { Inequality (Gini } \\
\text { using SES) } \\
\end{array}$ & Inequality (Gini) & $\begin{array}{c}\text { Inequality (Gini } \\
\text { using SES) }\end{array}$ \\
\hline$\%$ For Openness Very Good SES & $\begin{array}{c}-0.05 \\
(0.26)\end{array}$ & $\begin{array}{c}-0.08 \\
(0.26)\end{array}$ & $\begin{array}{c}0.01 \\
(0.26)\end{array}$ & $\begin{array}{l}-0.07 \\
(0.26)\end{array}$ \\
\hline$\%$ For Openness Good SES & $\begin{array}{c}-0.05 * * * \\
(0.14)\end{array}$ & $\begin{array}{c}-.47 * * * \\
(0.13)\end{array}$ & $\begin{array}{c}-0.55 * * * \\
(0.14)\end{array}$ & $\begin{array}{c}-0.51 * * * \\
(0.15)\end{array}$ \\
\hline$\%$ For Openness Not Bad SES & $\begin{array}{l}0.27^{*} \\
(0.11)\end{array}$ & $\begin{array}{c}.33^{*} \\
(0.12)\end{array}$ & $\begin{array}{l}0.32 * * \\
(0.12)\end{array}$ & $\begin{array}{l}0.31^{*} \\
(0.13)\end{array}$ \\
\hline \% For Openness Bad SES & $\begin{array}{l}-0.38 \\
(0.26)\end{array}$ & $\begin{array}{l}-0.47^{\circ} \\
(0.27)\end{array}$ & $\begin{array}{l}-0.43 \\
(0.26)\end{array}$ & $\begin{array}{l}-0.41 \\
(0.28)\end{array}$ \\
\hline \% For Openness Very Bad SES & $\begin{array}{l}-0.05 \\
(0.61)\end{array}$ & $\begin{array}{l}-0.36 \\
(0.68)\end{array}$ & $\begin{array}{c}0.07 \\
(0.63)\end{array}$ & $\begin{array}{l}-0.07 \\
(0.76)\end{array}$ \\
\hline Corruption * Inequality & $\begin{array}{c}0.01 \\
(0.03)\end{array}$ & $\begin{array}{c}0.07 \\
(0.08)\end{array}$ & - & - \\
\hline Inequality & - & - & $\begin{array}{c}-1.13 * * \\
(0.44)\end{array}$ & $\begin{array}{c}0.11 \\
(0.64)\end{array}$ \\
\hline Corruption & - & - & $\begin{array}{c}1.65 \\
(1.40)\end{array}$ & $\begin{array}{c}1.20 \\
(1.37)\end{array}$ \\
\hline GDP per capita (thousands) & $\begin{array}{c}2.33 * * \\
(0.76)\end{array}$ & $\begin{array}{c}2.26 * * \\
(0.73)\end{array}$ & $\begin{array}{c}1.02 \\
(0.81)\end{array}$ & $\begin{array}{c}2.35 * * * \\
(0.73)\end{array}$ \\
\hline Democracy & $\begin{array}{c}0.53 \\
(0.60)\end{array}$ & $\begin{array}{c}0.62 \\
(0.60)\end{array}$ & $\begin{array}{c}0.91 \\
(0.62)\end{array}$ & $\begin{array}{c}0.62 \\
(0.60)\end{array}$ \\
\hline Right Regime & $\begin{array}{c}1.99 \\
(2.03)\end{array}$ & $\begin{array}{c}1.77 \\
(2.03)\end{array}$ & $\begin{array}{c}1.38 \\
(2.07)\end{array}$ & $\begin{array}{c}1.78 \\
(2.04)\end{array}$ \\
\hline Left Regime & $\begin{array}{c}12.48 * * * \\
(2.20)\end{array}$ & $\begin{array}{c}12.44 * * * \\
(2.08)\end{array}$ & $\begin{array}{c}10.61 * * * \\
(2.32)\end{array}$ & $\begin{array}{c}12.80 * * * \\
(2.11)\end{array}$ \\
\hline Constant & $47.11 * * *$ & $41.63 * * *$ & $97.60 * * *$ & $33.70 *$ \\
\hline $\mathrm{N}$ & 187 & 187 & 187 & 187 \\
\hline Overall R-Squared & 0.04 & 0.04 & 0.002 & 0.04 \\
\hline
\end{tabular}

Table 2 reports the results for each of the models when the Gini index is used as the measure of inequality and when Gini using SES is used as the measure of inequality.

\footnotetext{
${ }^{74}$ It could be the case that one regime negotiates a trade agreement and then another regime comes to power before ratification, in this case the new regime could back out of the agreement and therefore still follow its ideology.
} 
Interestingly, the results for the impact of public opinion on the level of trade openness in a country point to those in the highest SES category not having any impact on trade policy, and if they do the impact is likely negative. Furthermore, the results for the preferences of those in the second highest SES category is significant, showing this does impact the level of trade openness in a state, but the coefficient is negative. This shows the more this category prefers openness the less openness there is. The only other SES category that has significant results in the positive direction is the middle category, these results show the more in this category that prefer trade the more trade openness. These results are similar to the results for the American chapter, indicating that it may be the middle class who is able to assert the greatest influence over trade policy. The coefficient for the corruption and inequality interaction term is not significant.

Table 2 also reports the results when inequality and corruption are included as separate independent variables. The results when trade openness is the dependent variable are similar to the results when corruption and inequality are interacted. Again, the results are pointing to only the not bad SES group having a positive and significant effect on trade policy. The main difference in these results is when inequality using the Gini index is included as an independent variable, the coefficient for inequality is significant and in the negative direction. This indicates that when there is greater inequality there is less trade openness, meaning there is likely increased pressure against openness as inequality increases.

Table 3 reports the results when public perceptions of union power and business power are used as measures of interest group influence. The results are somewhat similar to when corruption is used but given the lower $\mathrm{N}$, the levels of significance are lower. Business power is significant at the $\mathrm{p} \leq 0.1$ level, but the sign is in the negative direction, while the sign for corruption was in the positive direction. This shows businesses might have less influence on 
trade policy when they are perceived as more powerful, or that businesses in Latin America may push for less trade openness when they have more power. The coefficient for union power is not significant in either of the regressions, showing unions likely have little influence over trade policy. Of the measures of public opinion on trade, only the percentage for openness in the very bad SES category is significant at the $\mathrm{p} \leq 0.05$ level in both models, the sign is in the negative direction. This shows when more people in the SES category prefer openness there is less trade

Table 3: Results when Public Perception of Union Power and Business Power are used as Measures of Interest Group Influence

\begin{tabular}{|c|c|c|}
\hline & Inequality (Gini) & Inequality (Gini using SES) \\
\hline \% For Openness Very Good SES & $\begin{array}{l}-0.43 \\
(0.31)\end{array}$ & $\begin{array}{l}-0.51 \\
(0.32)\end{array}$ \\
\hline \% For Openness Good SES & $\begin{array}{l}-0.13 \\
(0.16)\end{array}$ & $\begin{array}{l}-0.03 \\
(0.18)\end{array}$ \\
\hline$\%$ For Openness Not Bad SES & $\begin{array}{c}0.19 \\
(0.14)\end{array}$ & $\begin{array}{l}0.27^{\circ} \\
(0.16)\end{array}$ \\
\hline$\%$ For Openness Bad SES & $\begin{array}{c}0.09 \\
(0.30)\end{array}$ & $\begin{array}{l}-0.07 \\
(0.32)\end{array}$ \\
\hline$\%$ For Openness Very Bad SES & $\begin{array}{l}-1.08 * \\
(0.47)\end{array}$ & $\begin{array}{l}-1.68^{*} \\
(0.73)\end{array}$ \\
\hline Union Power & $\begin{array}{l}-0.01 \\
(0.17)\end{array}$ & $\begin{array}{c}0.01 \\
(0.17)\end{array}$ \\
\hline Business Power & $\begin{array}{l}-0.15^{\circ} \\
(0.09)\end{array}$ & $\begin{array}{l}-0.14^{\circ} \\
(0.09)\end{array}$ \\
\hline Inequality & $\begin{array}{c}0.21 \\
(0.60)\end{array}$ & $\begin{array}{c}0.96 \\
(0.84)\end{array}$ \\
\hline GDP per capita (thousands) & $\begin{array}{l}-0.96 \\
(1.19)\end{array}$ & $\begin{array}{l}-1.41 \\
(1.05)\end{array}$ \\
\hline Democracy & $\begin{array}{c}1.12 \\
(0.74)\end{array}$ & $\begin{array}{c}1.20 \\
(0.76)\end{array}$ \\
\hline Right Regime & $\begin{array}{l}-3.00 \\
(2.45)\end{array}$ & $\begin{array}{l}-3.12 \\
(2.50)\end{array}$ \\
\hline Left Regime & $\begin{array}{l}5.87^{\circ} \\
(3.06)\end{array}$ & $\begin{array}{l}5.07^{\circ} \\
(2.94)\end{array}$ \\
\hline Constant & $59.22^{\circ}$ & $54.79 * * *$ \\
\hline $\mathrm{N}$ & 136 & 136 \\
\hline Overall R-Squared & 0.02 & 0.06 \\
\hline
\end{tabular}

openness, showing those at the bottom likely have little or no influence over trade policy, which was expected. Of the other variables measuring public opinion on trade only the percent for openness in the not bad SES category is significant at any level. The percentage for openness in 
the not bad SES category is significant at the $\mathrm{p} \leq 0.1$ and is in the positive direction. This provides some very limited evidence that the middle class may have influence on trade policy.

The results from the regressions do provide some evidence of inequality having an impact on trade policy, and of perhaps the middle class having the largest impact on trade policy. Thus, there is some support for the first hypothesis, influence does increase with income, to an extent, however, there is no support for the second hypothesis. I now move on to examining the individual level, particularly to exploring how inequality impacts political participation in Latin America.

\section{Individual Level Assumptions}

In order to better understand the forces impacting trade policy I explore the individual level assumptions of my theory. This also has the benefit of helping to fill in the gaps and explain why my theory fell short in some places. There are additional advantages to examining the individual level. The individual level gives a more nuanced view of how people of different socioeconomic groups participate, looking beyond voting to other forms of participation such as working for a political campaign, giving to a political campaign, and participating in a union or an interest group. This approach also allows for examining how much influence the public believes other groups have on politics.

Two of the key assumptions of my theory are, as inequality increases the wealthy participate at relatively higher rates, and as inequality increases middle and lower income individuals participate at relatively lower rates. To explore how the political participation of income groups changes with inequality I generated several scatter plots of various aspects of political participation, broken down by SES category in the Latinobarometer, and looking across 
both the measures of income inequality that I use above, the Gini index and Gini created using SES from the Latinobarometer.

The Latinobarometer asks respondents several questions about their political activities. In order to explore the general assumption inherent in the first two hypotheses, that higher income individuals participate relatively more as inequality increases and middle and lower income individuals participate relatively less as inequality increases, I need to examine as many types of participation as possible. Exploring several different types of participation is necessary because people can participate in politics in several different ways, therefore looking at only one form of participation, such as voting, does not fully capture a group's level of participation. The different types of participation that I explore are participating in an authorized demonstration, participating in an unauthorized demonstration, working for a political party, belonging to a political party, belonging to a labor union, voting in the last presidential election, signing a petition, blocking traffic, rioting, and occupying buildings and factories. These forms of participation give a mix of both contentious and non-contentious political activities, thus do not exclude one type of activity in favor of another. As discussed above, the Latinobarometer does not ask the same questions every year, Appendix 9 contains the years for which each question on participation was asked.

Each of the scatter plots has the measure of inequality on the x-axis and the percentage of a given SES group in a country who say they have engaged in a given political activity on the yaxis. This method gives a visual showing if there is an increase or decrease in political activity among an SES group as inequality changes. If there is an increase in political activity among a group as inequality increases then the trend will be positive, and the trendline will show a 
positive slope, while if there is a decrease in political activity as inequality increases the overall trend will be negative, and the trend line will show a negative slope.

Figure 2: Percent of each SES category in each country in the Latinobarometer that voted in the last presidential election by inequality using the Gini index as the measure of inequality
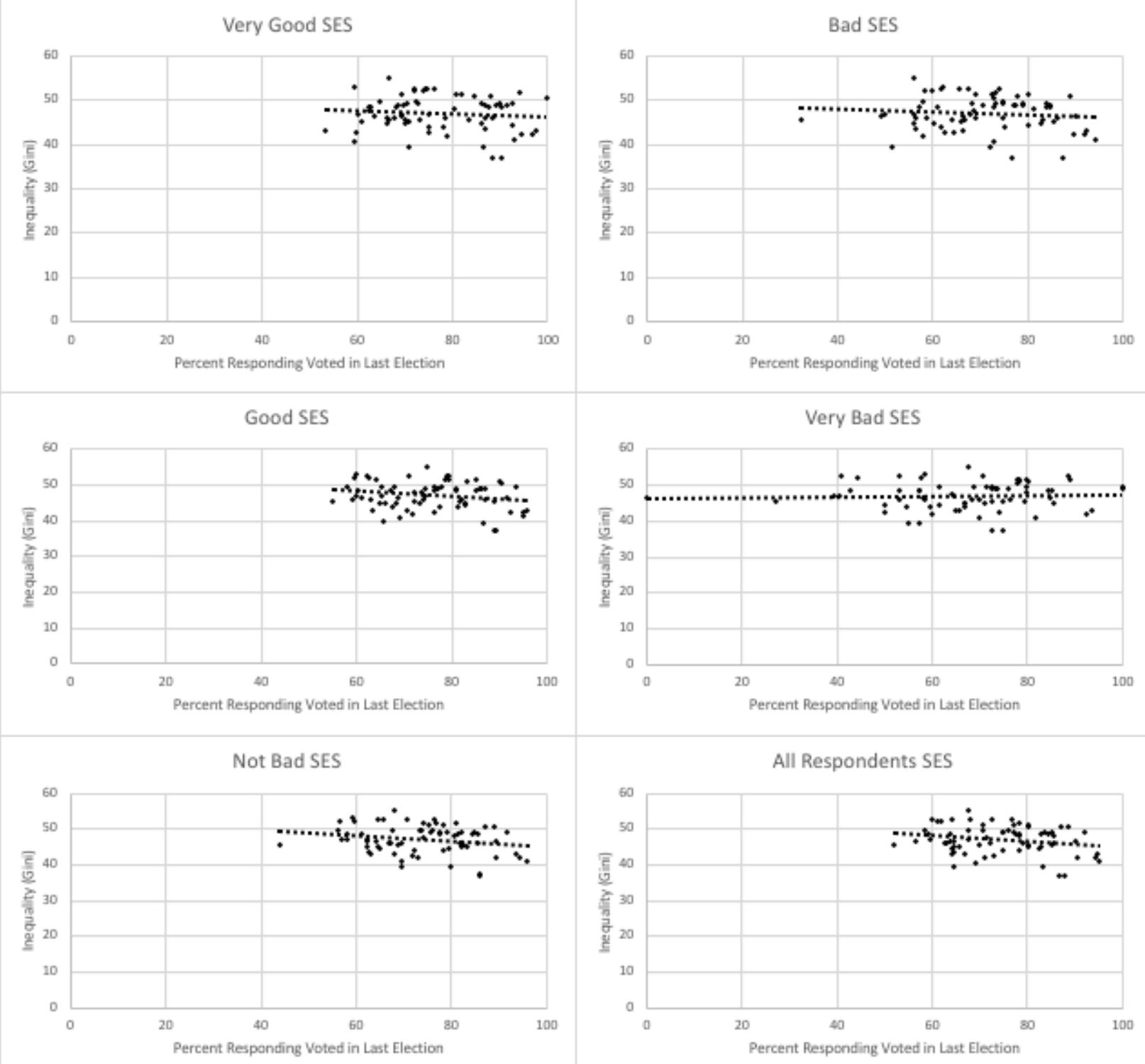

Beginning with examining how voting changes with inequality, Figure 2 has six scatter plots showing the percentage of each SES category in each country in the Latinobarometer that voted in the last presidential election by inequality using the Gini index as the measure of inequality. For all respondents the overall trend is negative, showing that as inequality increases 
there is lower voter turnout; this is expected, given that political participation overall by the public is expected to decline as inequality increases. Moving on to examining voter turnout by SES. If the relative political participation, in this case measured by voter turnout, of those with a higher SES increases with inequality then, relative to the other SES groups, participation by those in the very good SES group should increase with inequality, this is not what is observed. For the top four SES groups voter turnout has a similar negative trend, while voter turnout for the bottom SES group is flat. This demonstrates, contrary to expectations, when political participation is measured as voter turnout, the relative participation of those in the top group does not increase compared to the other groups, rather it is the relative participation of those in the very bad SES group that increases. These scatter plots were also made with Gini using SES as the measure of inequality, this figure is in Appendix 10, the results were very similar to the results when the Gini index was used as the measure of inequality.

Moving on to examining other forms of political participation, Appendixes 11 through 19 include participating in an authorized demonstration, participating in an unauthorized demonstration, working for a political party, belonging to a political party, belonging to a labor union, signing a petition, blocking traffic, rioting, and occupying buildings and factories. The results for these activities are mixed.

Beginning with participating in authorized demonstrations, when Gini using SES is used as the measure of inequality, for each of the SES groups as the level of inequality increases, participation decreases. However, when the Gini index is used as the measure of inequality this decline occurs for only the top two SES groups, while participation by the bottom three groups is relatively unchanged with inequality. This points to a trend that as inequality increases the bottom three groups participate relatively more in demonstrations. This is contrary to 
expectations but does help to explain the results in the American chapter that pointed to the middle groups having the most influence.

The results for participating in unauthorized demonstrations somewhat contradict these results, when the Gini index is used as the measure of inequality the top three groups engage in more protests at higher levels of inequality, while participation for the bottom two groups is relatively unchanged. This provides some limited evidence that the bottom groups may participate less, and the top groups may participate more as inequality increases. When Gini using SES is used as the measure of inequality participation in unauthorized protests by the very good SES group, the not bad SES, and the bad SES group declines slightly as inequality increases. For the good and very bad SES groups participation in unauthorized protests increases slightly with inequality. These results show the picture may be more complex than originally expected. Income inequality may have one impact on political activity, while inequality in SES may have another, but more investigation is needed to determine if this is the case.

When it comes to participation in the form of working for a political party, when the Gini index is used as the measure of inequality there is a slight decline in participation for each of the SES groups as inequality increases, but overall participation remains relatively flat. The case is similar for when Gini using SES is used as the measure of inequality, the top two groups experience a slight decline in participation as inequality increases, while the lower middle two groups experience a slight increase. Overall participation is relatively unchanged, the exception is that the bottom group experiences a clear, but not large, increase in participation as inequality increases, again not what would be expected. Interestingly, these results are mirrored when it comes to party membership. When the Gini index is used as the measure of inequality, at higher levels of inequality the top four groups are slightly less likely to be a member of a political party 
while the bottom group is more likely to be a member. It could be as inequality increases those at the bottom see participation in a political party as a way to have a voice, given that they are relatively less well-off under higher inequality; however, it does not appear this increased participation leads to greater influence when compared to the regression results. When Gini using SES is used as the measure of inequality, again the top four groups see a decline in participation at higher levels of inequality while for the bottom group participation is relatively unchanged.

The results for union membership almost mirror the results for party membership. When the Gini index is used as the measure of inequality participation in a union remains relatively flat for the top group and the not bad SES group and declines slightly as inequality increases for the good SES group and the bad SES group. However, union participation steeply increases with inequality for the very bad SES group. When Gini using SES is used as the measure of inequality union membership declines at higher inequality for the top four groups but increases slightly for the bottom group. Again, this demonstrates that those at the very bottom might participate more in some activities as inequality increases, likely doing this as a way to try and remedy some of the impacts of inequality.

When it comes to the activities of signing a petition, blocking traffic, rioting, and occupying buildings or factories the results again show a mixed picture. Looking at signing a petition, for both measures of inequality, the likelihood of signing a petition declines as inequality increases for all SES groups. For the more disruptive activities of blocking traffic, rioting, and occupying buildings or factories the results are mixed. Most notable are the results for rioting and occupying buildings or factories when Gini using SES is used as the measure of inequality. Across the top four groups, for each of these types of participation, inequality either 
has a negative effect on participation or almost no effect. However, for the not bad SES group participating in a riot and occupying buildings or factories increases with inequality. These results again show that as inequality increases those at the bottom might actually participate more in some activities, but the results of the regressions in this chapter and the previous chapter do not show this participation by those at the bottom translating into policy. Increased political activity by those at the bottom as inequality increases would certainly reflect Latin America's past. In Latin America there was a rise of left wing mass-based groups in response to the neoliberal policies that allowed for business expansion (Hogenboom and Jilberto 2012).

The overall results for participation at higher levels of inequality show across the population, as inequality increases participation in authorized demonstrations, petitioning the government, rioting, occupying buildings or factories, union membership, political party membership, and voting all decline with inequality. This decline in participation gives a clear gap in which interest groups can assert themselves. However, given that those at the bottom might participate more as inequality increases, this gap might not be as large as first expected.

Moving on to examining the assumptions regarding interest group participation and inequality. The underlying assumptions about interest groups are, business interest groups will be able to have more influence over policy as inequality increases, and mass-based interest groups will have less influence on policy as inequality increases.

Figure 3 shows the scatter plots for those mentioning unions are one of the three most powerful groups. Figure 4 shows the scatter plots for those mentioning businesses as one of the three most powerful groups. Both of these sets of figures use the Gini index as the measure of inequality. Results when Gini using SES is used as the measure of inequality are in Appendix 20 for unions and Appendix 21 for businesses. Figure 2 shows that, across SES categories, when 
Figure 3: Percent of each SES category in each country in the Latinobarometer responding unions are one of the three most powerful groups in their country by inequality using the Gini index as the measure of inequality
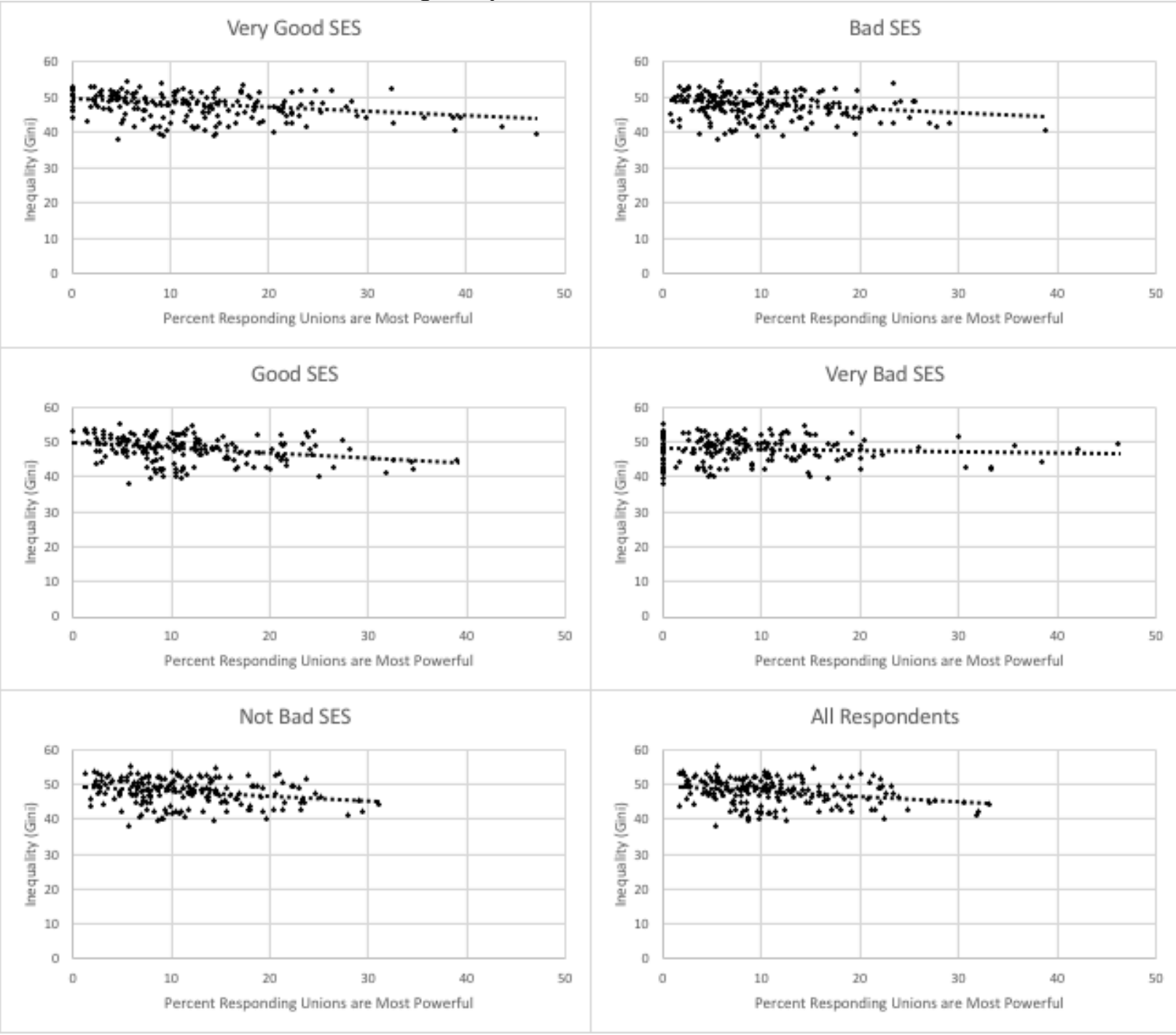

inequality is higher people are less likely to respond that unions are the most powerful group in the country; the results are the same for when Gini using SES is used as the measure of inequality. This is clear evidence to support the idea that as inequality increases the influence of unions decreases. Interestingly, the very bad SES group shows only a very slight, almost flat, response as inequality increases, much less of an incline than the other groups. This could be related to those in the very bad SES group being more likely to join a union when inequality is higher, people would likely not join a union if they believed the union would have little power 
and joining a union/remaining in a union could be seen as a way to try and remedy some of the effects of inequality.

Figure 4: Percent of each SES category in each country in the Latinobarometer responding businesses are one of the three most powerful groups in their country by inequality using the Gini index as the measure of inequality
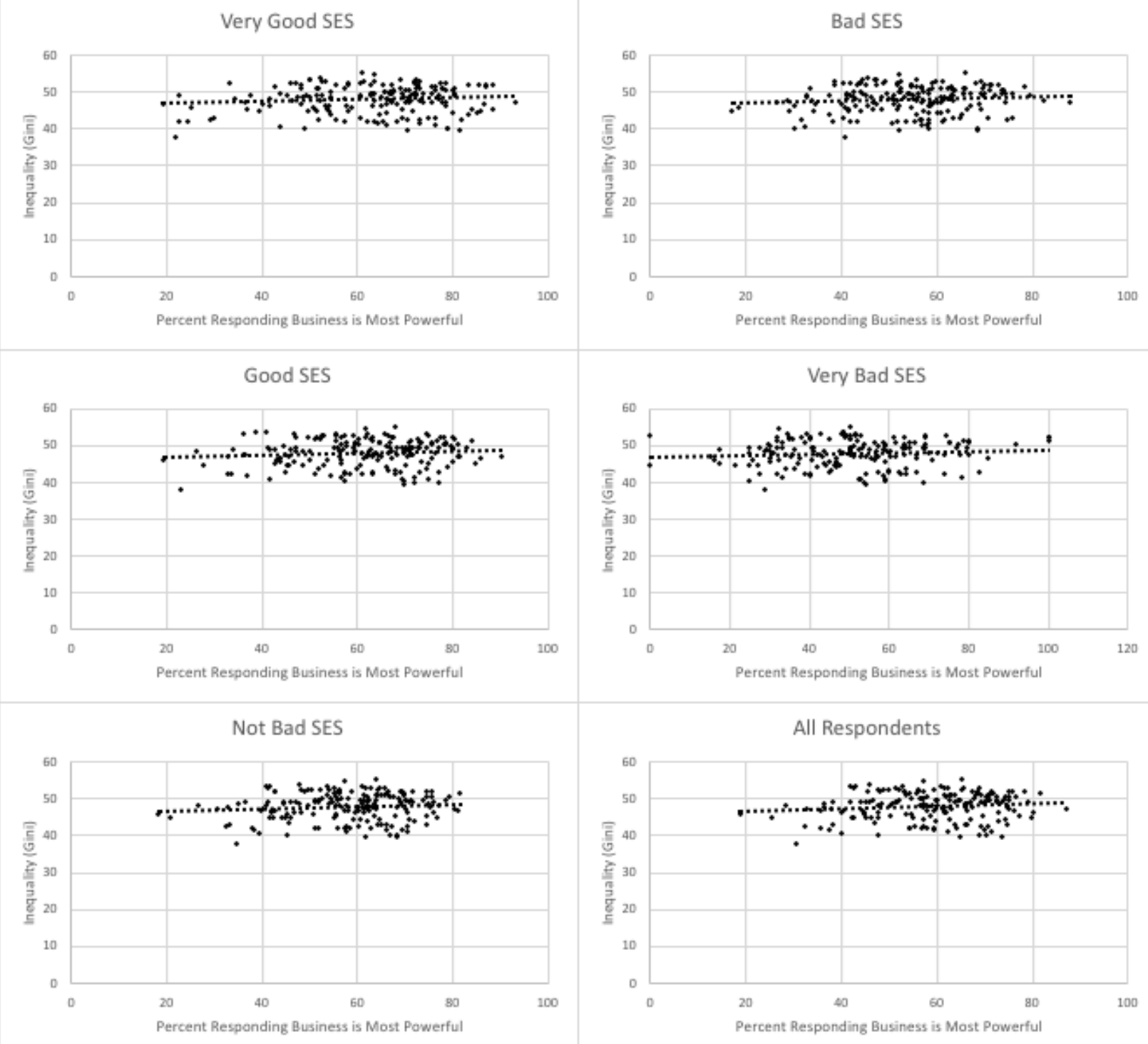

Figure 4 gives the results for people responding that businesses are one of the most powerful groups. Across all of the SES groups responses show that when there is greater inequality the public is more likely to respond that business interest groups are one of the most 
powerful groups in the country. These results support the assumption that business interest groups have more influence as inequality increases. However, the results in Appendix 21, when Gini using SES is used as the measure of inequality, are not similar. These results show, across SES groups at higher levels of inequality, respondents are less likely to mention businesses as one of the most powerful groups than at lower levels of inequality; yet, for the majority of groups, while the difference is only slight, it still exists. It is not clear why these results are what they are, more investigation is needed to determine how each of these types of inequality interact to influence public opinion. Overall, figures 3 and 4 do give support to the underlying assumptions in hypotheses 3 and 4 .

Finally, when it comes to the regression results, there could be the issue that trade preferences do not respond to inequality. Figures 4 and 5 show public support of trade openness by inequality, these figures show that the trade preferences of the public as reported by the Latinobarometer do vary with inequality. Both of these figures show for those in the good, not bad, bad, and very bad SES categories and for all respondents, as inequality increases support for trade openness decreases. This provides evidence that the public becomes more against trade at higher levels of inequality, perhaps seeing trade as a cause of that inequality. ${ }^{75}$ The difference is with the very good SES category. When the Gini index is used as the measure of inequality, as inequality increases those in the highest SES category are more in favor of trade, showing the wealthy likely see trade as benefitting them as inequality increases. Although this might not be

\footnotetext{
${ }^{75}$ Many people in Latin America could also be against greater trade openness because of the neoliberal reforms Latin American countries were required to undergo as a result of the Washington Consensus and the International Monetary Fund. These reforms helped to open up Latin American economies, and in the process further increased inequality in Latin America (Cárdenas 2010). Given this, many people in Latin America likely see greater trade openness as a cause of higher inequality.
} 
the case, given that when Gini using SES is the measure of inequality, as with the other SES categories, as inequality increases those in the very good SES category are less in favor of trade.

Figure 4: Percent of each SES category in each country in the Latinobarometer that responded they are in favor of trade openness by inequality using the Gini index as the measure of inequality
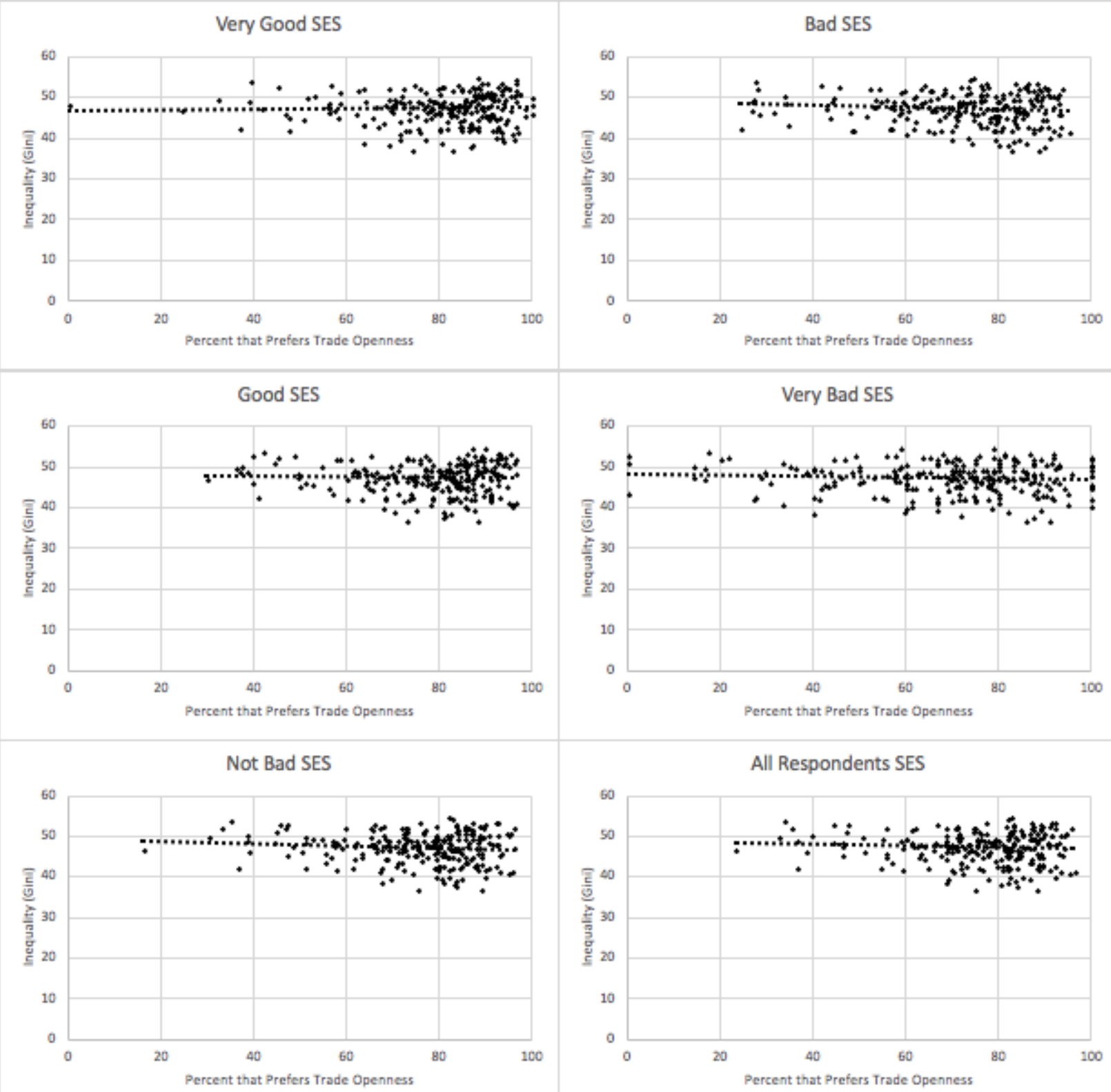
Figure 5: Percent of each SES category in each country in the Latinobarometer that responded they are in favor of trade openness by inequality using Gini using SES as the measure of inequality
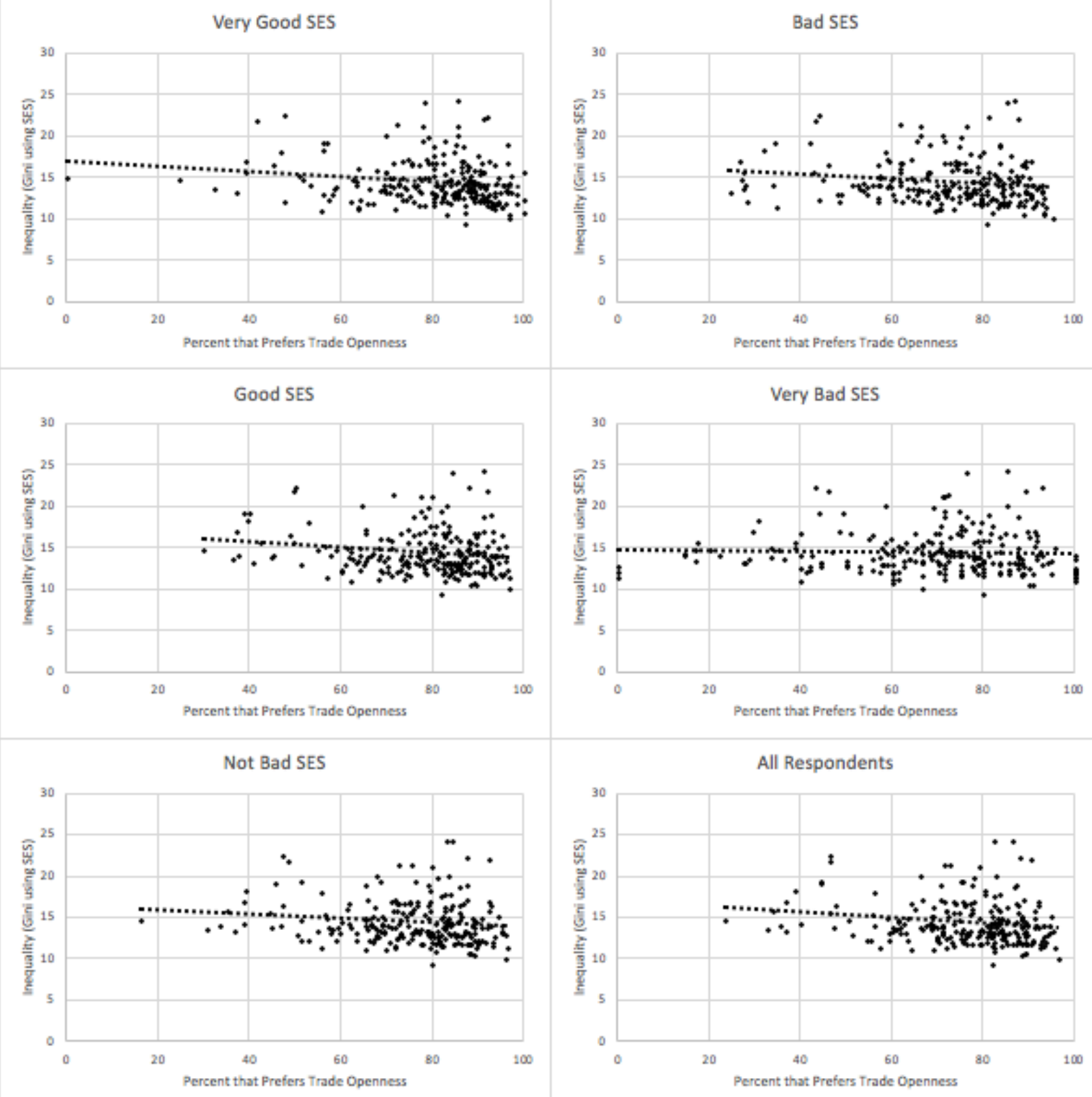

\section{Discussion and Conclusion}

There are several methodological reasons why the results may not be significant for the regressions. The first methodological issue is the low $\mathrm{N}$. The $\mathrm{N}$ is particularly low for use with cross-sectional time series. This challenge results from the sparseness of public opinion data. 
Problems likely also arise from using questions on the integration of Latin America as a proxy for preferences on trade openness. Someone who is in favor of Latin American integration may not be in favor of trade outside Latin America. Additional challenges to testing this theory also come from teasing out the interaction effects of inequality, public opinion, and interest groups.

There is also the disadvantage of the measures of interest group influence. The measures using public opinion of the power of unions and interest groups relies on the public's assessment of how much power businesses and unions have, and the public may not be accurate in their assessment. This could especially be the case when these groups engage in corruption to influence politicians. Since corruption is not a transparent activity the public will not always know who has influence, this measure relies on the public paying attention to the media for stories of corruption that are brought to light. Also, unlike an objective measure of influence, such as campaign contributions, the public is likely to be biased in their assessment of whether or not unions and businesses are powerful. It could be the case that a union member sees unions as less powerful because they believe unions should be more powerful, the same could be true for a business owner and the power of businesses.

Next, there is the possibility that corruption may not be the best proxy variable for lobbying. The expectation was that corruption and formal lobbying (formal interest group spending in the American chapter) are substitutes, as corruption decreased interest group spending would increase. This may not be the case. It may be the case that some groups are using these as complements, using corruption when it suits them but also engaging in legal lobbying activities when it suits them. There is the possibility corruption is less of a proxy for interest group spending and it is simply measuring corruption in a country, measuring corruption among government bureaucrats, not just policy makers. There is also the problem that the CPI is 
a broad measure and therefore captures corruption beyond policy makers and does not provide a direct measure of policy maker activity. The use of the measures using public opinion of the power of unions and interest groups helps to alleviate some of these issues, but then the low $\mathrm{N}$ problem is again run into.

Resolving these issues will be difficult given that many Latin American countries do not collect or report interest group spending or public giving to candidates (Casas-Zamora and Zovatto 2016). However, the individual level results do point to the public viewing business interest groups as more powerful and unions as less powerful as inequality increases. This shows the influence of these groups on trade policy may change with inequality. Given the strong results regarding the influence of interest groups in Chapter IV on trade policy, this is likely the case. A way forward will be discussed in the conclusion. 


\section{Appendix 1: Latinobarometer, Openness Index Questions}

1995 Generally speaking, are you in favor of, or against, the economic integration of the countries of Latin America, even if this implies certain costs or sacrifices for [nationals]?

1996 Generally speaking, do you think that trade with other countries, both the buying and selling of products, helps [nation's] economy or harms [nation's] economy?

1997 Generally speaking, are you in favor of, or against, the economic integration of the countries of Latin America, even if this implies certain costs or sacrifices for [nationals]?

1998 Generally speaking, are you in favor of, or against, the economic integration of the countries of Latin America? Would you say that you are very in favor, quite in favor, slightly against or very against it?

2001 As you know, there are some conversations to establish in 2005 a Free Trade Area of the Americas that involve all Latin America, US and Canada. Do you think the establishment of the Free Trade Area of the Americas will help a lot, will fairly help will little help or will not help at all to the economic development of your country?

2002 Generally speaking, are you very in favor, quite in favor, slightly against or very against of the economic integration of the countries of Latin America?

2003 As far as you know or have heard, how do you think the Free Trade Agreements (NAFTA, CAFTA) and the Commercial Agreements benefit you and your family? Would you say they benefit you very much, somewhat benefit you, benefit you a little or they don't benefit you at all?

2004 Do you believe that international free trade treaties have a very positive, positive, negative, very negative impact, it doesn't have any impact over the job opportunities, or do you feel you don't know enough to give an opinion?

2005 Generally speaking, are you very in favour, quite in favour, slightly against or very against of the economic integration of the countries of Latin America?

2006 With which Latin American country would you prefer to have an economic integration agreement or do you think they should exist with all Latin American countries? Or do you have insufficient information to answer? (possible response of none)

2007 Do international free trade treaties have a very positive, positive, negative or very negative impact?

2008 Generally speaking, are you very in favour, quite in favour, slightly against or very against of the economic integration of the countries of Latin America?

2009 Generally speaking, are you very in favour, quite in favour, slightly against or very against of the economic integration of the countries of Latin America?

2010 Generally speaking, are you very in favour, quite in favour, slightly against or very against of the economic integration of the countries of Latin America?

2015 Do you strongly agree, agree, disagree or strongly disagree with the following statements? That (country) can buy goods and services from any other country and that any other country can sell goods and services in (country) 


\section{Appendix 2: Latino Barometer, Trade Openness Regional Index Questions}

1995 Generally speaking, are you in favor of, or against, the economic integration of the countries of Latin America, even if this implies certain costs or sacrifices for [nationals]?

1996 Generally speaking, are you in favor of, or against, the economic integration of the countries of Latin America, even if this implies certain costs or sacrifices for [nationals]?

1997 Generally speaking, are you in favor of, or against, the economic integration of the countries of Latin America, even if this implies certain costs or sacrifices for [nationals]?

1998 Generally speaking, are you in favor of, or against, the economic integration of the countries of Latin America? Would you say that you are very in favor, quite in favor, slightly against or very against it?

2001 Generally speaking, are you in favor of, or against, the economic integration of the countries of Latin America? Would you say that you are very in favor, quite in favor, slightly against or very against it?

2002 Generally speaking, are you very in favor, quite in favor, slightly against or very against of the economic integration of the countries of Latin America?

2003 All things considered, would you say that (nation) benefits a lot, quite a lot, a little, not at all, or you don't know enough to offer an opinion, from belonging to (regional trading block according to the country: MERCOSUR, Andean Pact or Common Market of Central America)...?

2005 Generally speaking, are you very in favour, quite in favour, slightly against or very against of the economic integration of the countries of Latin America?

2006 With which Latin American country would you prefer to have an economic integration agreement or do you think they should exist with all Latin American countries? Or do you have insufficient information to answer? (possible response of none)

2007 Would you strongly agree, agree, disagree or strongly disagree with a decision to take the following measures in order to increase regional integration? The elimination of import and export taxes

2008 Generally speaking, are you very in favour, quite in favour, slightly against or very against of the economic integration of the countries of Latin America?

2009 Generally speaking, are you very in favour, quite in favour, slightly against or very against of the economic integration of the countries of Latin America?

2010 Generally speaking, are you very in favour, quite in favour, slightly against or very against of the economic integration of the countries of Latin America?

2016 Imagine that (country) signs an agreement of integration with other countries. Do you very agree (1), agree (2), disagree (3) or very disagree (4) with the following affirmations? Country) could buy goods and services from any other country in the region and that any other country could sell goods and services in (Country) 
Appendix 3: Summary Statistics for Additional Measures of Business Power

\begin{tabular}{|c|c|c|c|c|}
\hline & Mean & Std. Dev. & Min. & Max. \\
\hline $\begin{array}{l}\text { Percent Identifying Large companies, Banks, or } \\
\text { Transnational Companies as Powerful }\end{array}$ & 58.30 & 12.59 & 18.7 & 87 \\
\hline $\begin{array}{l}\text { Percent Identifying Large Companies, Medium } \\
\text { Sized Companies, or Transnational }\end{array}$ & 51.70 & 12.76 & 15.3 & 79.5 \\
\hline $\begin{array}{l}\text { Percent Identifying Large Companies or } \\
\text { Transnational Companies as Powerful }\end{array}$ & 50.40 & 13.09 & 15.3 & 79.5 \\
\hline Percent Identifying Large Companies as Powerful & 45.41 & 11.42 & 15.3 & 72.9 \\
\hline Percent Identifying Banks as Powerful & 19.88 & 8.21 & 3.3 & 47.34 \\
\hline
\end{tabular}


Appendix 4: Regression Results (with percent identifying large companies, banks, or transnational companies as powerful as the measure of business power)

\begin{tabular}{|c|c|c|}
\hline & Inequality (Gini) & Inequality (Gini using SES) \\
\hline$\%$ For Openness Very Good SES & $\begin{array}{l}-0.51 \\
(0.32)\end{array}$ & $\begin{array}{l}-0.58^{\circ} \\
(0.34)\end{array}$ \\
\hline$\%$ For Openness Good SES & $\begin{array}{l}-0.24 \\
(0.18)\end{array}$ & $\begin{array}{l}-0.16 \\
(0.21)\end{array}$ \\
\hline$\%$ For Openness Not Bad SES & $\begin{array}{c}0.16 \\
(0.16)\end{array}$ & $\begin{array}{c}0.23 \\
(0.17)\end{array}$ \\
\hline \% For Openness Bad SES & $\begin{array}{c}0.32 \\
(0.31)\end{array}$ & $\begin{array}{c}0.19 \\
(0.33)\end{array}$ \\
\hline \% For Openness Very Bad SES & $\begin{array}{c}-1.56^{* * *} \\
(0.46)\end{array}$ & $\begin{array}{l}-1.93 * * \\
(0.74)\end{array}$ \\
\hline Union Power & $\begin{array}{l}-0.11 \\
(0.19)\end{array}$ & $\begin{array}{l}-0.02 \\
(0.19)\end{array}$ \\
\hline Business Power & $\begin{array}{l}-0.01 \\
(0.08)\end{array}$ & $\begin{array}{c}0.01 \\
(0.09)\end{array}$ \\
\hline Inequality & $\begin{array}{c}0.84 \\
(0.87)\end{array}$ & $\begin{array}{c}0.67 \\
(0.87)\end{array}$ \\
\hline GDP per capita (thousands) & $\begin{array}{c}0.72 \\
(1.64)\end{array}$ & $\begin{array}{l}-0.46 \\
(1.51)\end{array}$ \\
\hline Democracy & $\begin{array}{c}0.70 \\
(0.85)\end{array}$ & $\begin{array}{c}0.69 \\
(0.86)\end{array}$ \\
\hline Right Regime & $\begin{array}{l}-5.96^{*} \\
(2.55)\end{array}$ & $\begin{array}{l}-5.52 * \\
(2.58)\end{array}$ \\
\hline Left Regime & $\begin{array}{c}4.81 \\
(3.56)\end{array}$ & $\begin{array}{c}4.06 \\
(3.67)\end{array}$ \\
\hline $\begin{array}{l}\text { Constant } \\
\mathrm{N}\end{array}$ & $\begin{array}{c}20.32 \\
118\end{array}$ & $\begin{array}{c}54.06 * * * \\
118\end{array}$ \\
\hline Overall R-Squared & 0.02 & 0.001 \\
\hline
\end{tabular}


Appendix 5: Regression Results (with percent identifying large companies, medium sized companies, or transnational companies as powerful as the measure of business power)

\begin{tabular}{lcc}
\hline & Inequality (Gini) & Inequality (Gini using SES) \\
\hline \% For Openness Very Good SES & $-0.57^{\circ}$ & $-0.64^{\circ}$ \\
\% For Openness Good SES & $0.32)$ & $(0.34)$ \\
& -0.25 & -0.17 \\
\% For Openness Not Bad SES & $(0.18)$ & $(0.21)$ \\
\% For Openness Bad SES & 0.15 & 0.22 \\
& $(0.16)$ & $(0.17)$ \\
\% For Openness Very Bad SES & 0.34 & 0.20 \\
& $(0.30)$ & $(0.33)$ \\
Union Power & $-1.60^{* * *}$ & $-1.99^{* *}$ \\
& $(0.46)$ & $(0.73)$ \\
Business Power & -0.07 & 0.01 \\
& $(0.19)$ & $(0.19)$ \\
Inequality & 0.06 & 0.07 \\
& $(0.08)$ & $(0.08)$ \\
GDP per capita (thousands) & 0.84 & 0.72 \\
& $(0.86)$ & $(0.86)$ \\
Democracy & 0.56 & -0.64 \\
& $(1.64)$ & $(1.50)$ \\
Right Regime & 0.50 & 0.52 \\
& $(0.85)$ & $(0.87)$ \\
Left Regime & $-5.56^{*}$ & $-5.16^{*}$ \\
Constant & $(2.54)$ & $(2.58)$ \\
$\mathrm{N}$ & 5.09 & 4.33 \\
Overall R-Squared & $(3.57)$ & $(3.67)$ \\
\hline Stand En & 19.65 & $52.77^{* * *}$ \\
\end{tabular}

Standard Errors are reported in parentheses. $* * *$ denotes significance at the 0.001 probability level $* *$ denotes significance at the 0.01 probability level; $*$ denotes significance at the 0.05 probability level; ${ }^{\circ}$ denotes significance at the 0.1 probability level. Colombia used as base category. 


\begin{tabular}{lcc}
$\begin{array}{l}\text { Appendix 6: Regression Results (with percent identifying large companies or transnational companies as } \\
\text { powerful as the measure of business power) }\end{array}$ & Inequality (Gini) & Inequality (Gini using SES) \\
\hline & $-0.54^{\circ}$ & $-0.62^{\circ}$ \\
\hline \% For Openness Very Good SES & $(0.32)$ & $(0.34)$ \\
\% For Openness Good SES & -0.25 & -0.17 \\
& $(0.18)$ & $(0.21)$ \\
\% For Openness Not Bad SES & 0.16 & 0.23 \\
& $(0.16)$ & $(0.17)$ \\
\% For Openness Bad SES & 0.34 & 0.2 \\
& $(0.31)$ & $(0.33)$ \\
\% For Openness Very Bad SES & $-1.59^{* * *}$ & $-1.98^{* *}$ \\
& $(0.46)$ & $(0.74)$ \\
Union Power & -0.08 & 0.003 \\
& $(0.19)$ & $(0.19)$ \\
Business Power & 0.03 & 0.05 \\
& $(0.08)$ & $(0.09)$ \\
Inequality & 0.83 & 0.71 \\
& $(0.87)$ & $(0.86)$ \\
GDP per capita (thousands) & 0.68 & -0.53 \\
& $(1.63)$ & $(1.49)$ \\
Democracy & 0.58 & 0.59 \\
& $(0.85)$ & $(0.87)$ \\
Right Regime & $-5.79^{*}$ & $-5.4^{*}$ \\
& $(2.53)$ & $(2.56)$ \\
Left Regime & 4.96 & 4.21 \\
& $(3.57)$ & $(3.68)$ \\
Constant & 20.32 & $52.96^{* * *}$ \\
N & 118 & 118 \\
Overall R-Squared & 0.02 & 0.002 \\
\hline Santard &
\end{tabular}

Standard Errors are reported in parentheses. ***denotes significance at the 0.001 probability level $* *$ denotes significance at the 0.01 probability level; ${ }^{*}$ denotes significance at the 0.05 probability level; ${ }^{\circ}$ denotes significance at the 0.1 probability level. Colombia used as base category. 


\begin{tabular}{lcc}
$\begin{array}{l}\text { Appendix 7: Regression Results (with percent identifying large companies as powerful as the measure of } \\
\text { business power) }\end{array}$ & Inequality (Gini) & Inequality (Gini using SES) \\
\hline & $-0.59^{\circ}$ & $-0.68^{*}$ \\
\hline \% For Openness Very Good SES & $(0.31)$ & $(0.32)$ \\
\% For Openness Good SES & -0.25 & -0.14 \\
& $(0.17)$ & $(0.20)$ \\
\% For Openness Not Bad SES & 0.17 & 0.26 \\
& $(0.16)$ & $(0.17)$ \\
\% For Openness Bad SES & 0.34 & 0.17 \\
& $(0.30)$ & $(0.32)$ \\
\% For Openness Very Bad SES & $-1.63^{* * *}$ & $-2.17^{* * *}$ \\
& $(0.45)$ & $(0.72)$ \\
Union Power & -0.01 & 0.06 \\
& $(0.19)$ & $(0.18)$ \\
Business Power & $0.20^{*}$ & $0.23^{*}$ \\
& $(0.10)$ & $(0.10)$ \\
Inequality & 0.71 & 0.93 \\
& $(0.85)$ & $(0.84)$ \\
GDP per capita (thousands) & $0.20)$ & -0.90 \\
& $(1.62)$ & $(1.48)$ \\
Democracy & -0.05 & -0.07 \\
& $(0.88)$ & $(0.89)$ \\
Right Regime & $-5.45^{*}$ & $-5.24^{*}$ \\
& $(2.46)$ & $(2.48)$ \\
Left Regime & 5.12 & 4.32 \\
& $(3.49)$ & $(3.58)$ \\
Constant & 24.97 & $47.47^{* *}$ \\
N & 118 & 118 \\
Overall R-Squared & 0.003 & 0.02 \\
\hline Stant & &
\end{tabular}

Standard Errors are reported in parentheses. ${ }^{* * *}$ denotes significance at the 0.001 probability level $* *$ denotes significance at the 0.01 probability level; ${ }^{*}$ denotes significance at the 0.05 probability level; ${ }^{\circ}$ denotes significance at the 0.1 probability level. Colombia used as base category. 


\begin{tabular}{lcc}
$\begin{array}{l}\text { Appendix 8: Regression Results (with percent identifying banks as powerful as the measure of business } \\
\text { power) }\end{array}$ & Inequality (Gini) & Inequality (Gini using SES) \\
\hline & $-0.58^{\circ}$ & $-0.68^{*}$ \\
\hline \% For Openness Very Good SES & $(0.32)$ & $(0.34)$ \\
\% For Openness Good SES & -0.23 & -0.11 \\
& $(0.18)$ & $(0.21)$ \\
\% For Openness Not Bad SES & 0.13 & 0.21 \\
& $(0.16)$ & $(0.17)$ \\
\% For Openness Bad SES & 0.40 & 0.25 \\
& $(0.31)$ & $(0.33)$ \\
\% For Openness Very Bad SES & $-1.60^{* * *}$ & $-2.14^{* * *}$ \\
& $(0.46)$ & $(0.75)$ \\
Union Power & -0.07 & 0.01 \\
& $(0.19)$ & $(0.18)$ \\
Business Power & 0.13 & 0.18 \\
& $(0.14)$ & $(0.15)$ \\
Inequality & 0.81 & 0.96 \\
& $(0.86)$ & $(0.89)$ \\
GDP per capita (thousands) & 0.74 & -0.50 \\
& $(1.62)$ & $(1.48)$ \\
Democracy & 0.50 & 0.54 \\
& $(0.83)$ & $(0.85)$ \\
Right Regime & $-5.63^{*}$ & $-5.30^{*}$ \\
& $(2.51)$ & $(2.54)$ \\
Left Regime & 4.93 & 4.01 \\
& $(3.54)$ & $(3.64)$ \\
Constant & 20.12 & $47.96^{* *}$ \\
N & 118 & 118 \\
Overall R-Squared & 0.03 & 0.0001 \\
\hline Sant &
\end{tabular}

Standard Errors are reported in parentheses. ***denotes significance at the 0.001 probability level $* *$ denotes significance at the 0.01 probability level; ${ }^{*}$ denotes significance at the 0.05 probability level; ${ }^{\circ}$ denotes significance at the 0.1 probability level. Colombia used as base category. 


\begin{tabular}{|c|c|}
\hline Question & Years Asked \\
\hline $\begin{array}{l}\text { Have you participated in authorized } \\
\text { demonstrations? }\end{array}$ & $\begin{array}{l}2002,2003,2004,2005,2006,2007,2008 \text {, } \\
2015\end{array}$ \\
\hline $\begin{array}{l}\text { Have you participated in unauthorized } \\
\text { demonstrations? }\end{array}$ & $2003,2005,2007,2015$ \\
\hline Have you worked for a political party? & $1996,1998,2004,2005,2008$ \\
\hline Do you belong to a labor union? & $1996,2007,2008$ \\
\hline Do you belong to a political party? & $1996,2007,2008$ \\
\hline Did have vote in the last presidential election? & $2000,2005,2006,2013$ \\
\hline $\begin{array}{l}\text { Have you engaged in the following political } \\
\text { activity? Signed a signed a petition }\end{array}$ & $2002,2004,2005,2006,2007,2008$ \\
\hline $\begin{array}{l}\text { Have you engaged in the following political } \\
\text { activity? Blocked traffic }\end{array}$ & $1995,1996,1998,2005$ \\
\hline $\begin{array}{l}\text { Have you engaged in the following political } \\
\text { activity? Rioted }\end{array}$ & $1995,2002,2005,2008$ \\
\hline $\begin{array}{l}\text { Have you engaged in the following political } \\
\text { activity? Occupied buildings or factories }\end{array}$ & $1995,1996,1998,2002,2005,2008$ \\
\hline $\begin{array}{l}\text { Who do you think has the most power in your } \\
\text { country? Businesses (can name up to three) }\end{array}$ & $\begin{array}{l}\text { 1995, 1996, 1997, 1998, 2000, 2001, 2003, } \\
\text { 2004, 2005, 2006, 2010 }\end{array}$ \\
\hline $\begin{array}{l}\text { Who do you think has the most power in your } \\
\text { country? Unions (can name up to three) }\end{array}$ & $\begin{array}{l}\text { 1995, 1996, 1997, 1998, 2000, 2001, 2003, } \\
\text { 2004, 2005, 2006, 2010 }\end{array}$ \\
\hline
\end{tabular}


Appendix 10: Percent of each SES category in each country in the Latinobarometer that voted in the last presidential election by inequality using Gini created using SES as the measure of inequality

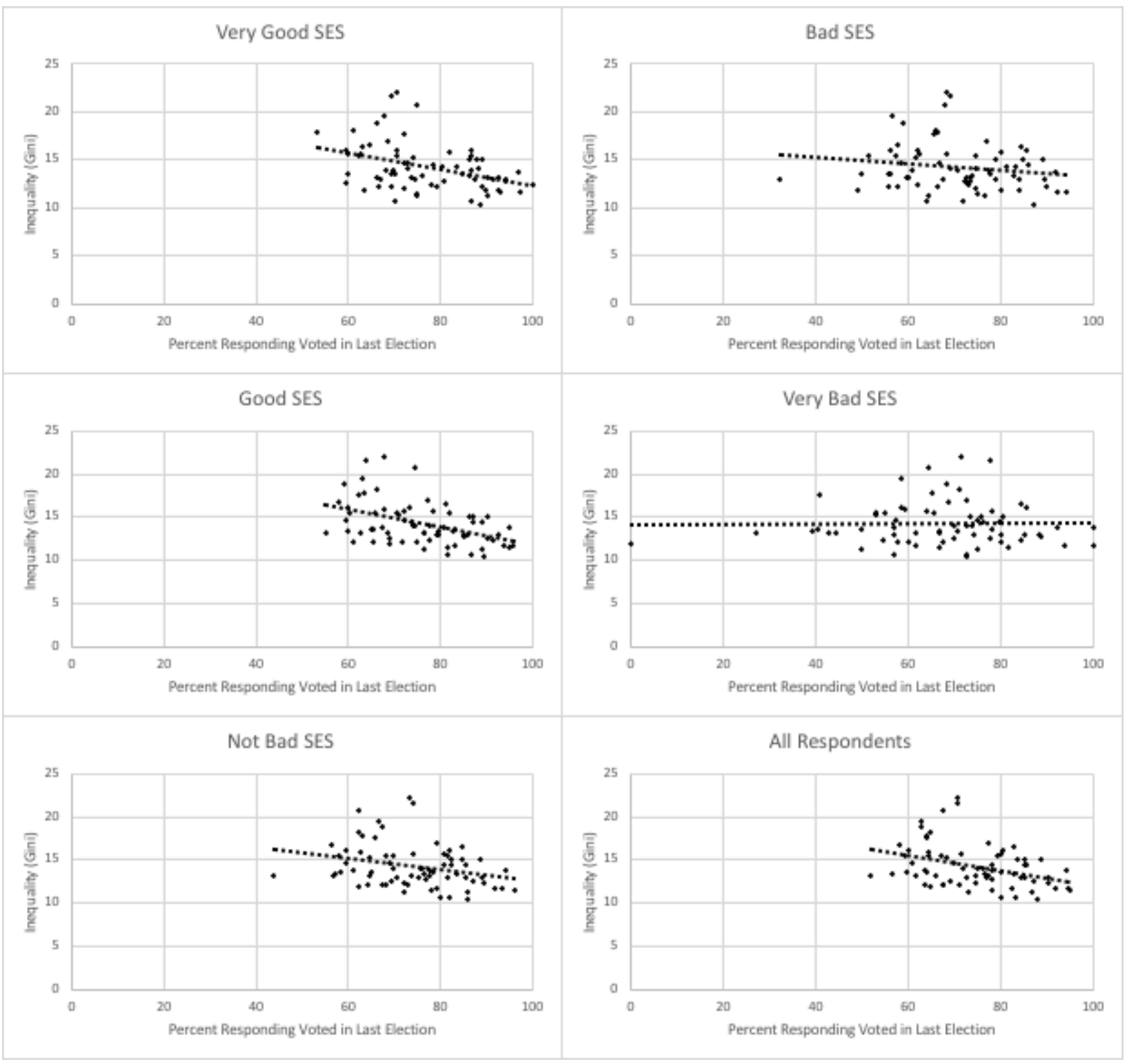


Appendix 11: Percent of each SES category in each country in the Latinobarometer responding they have participated in authorized demonstrations
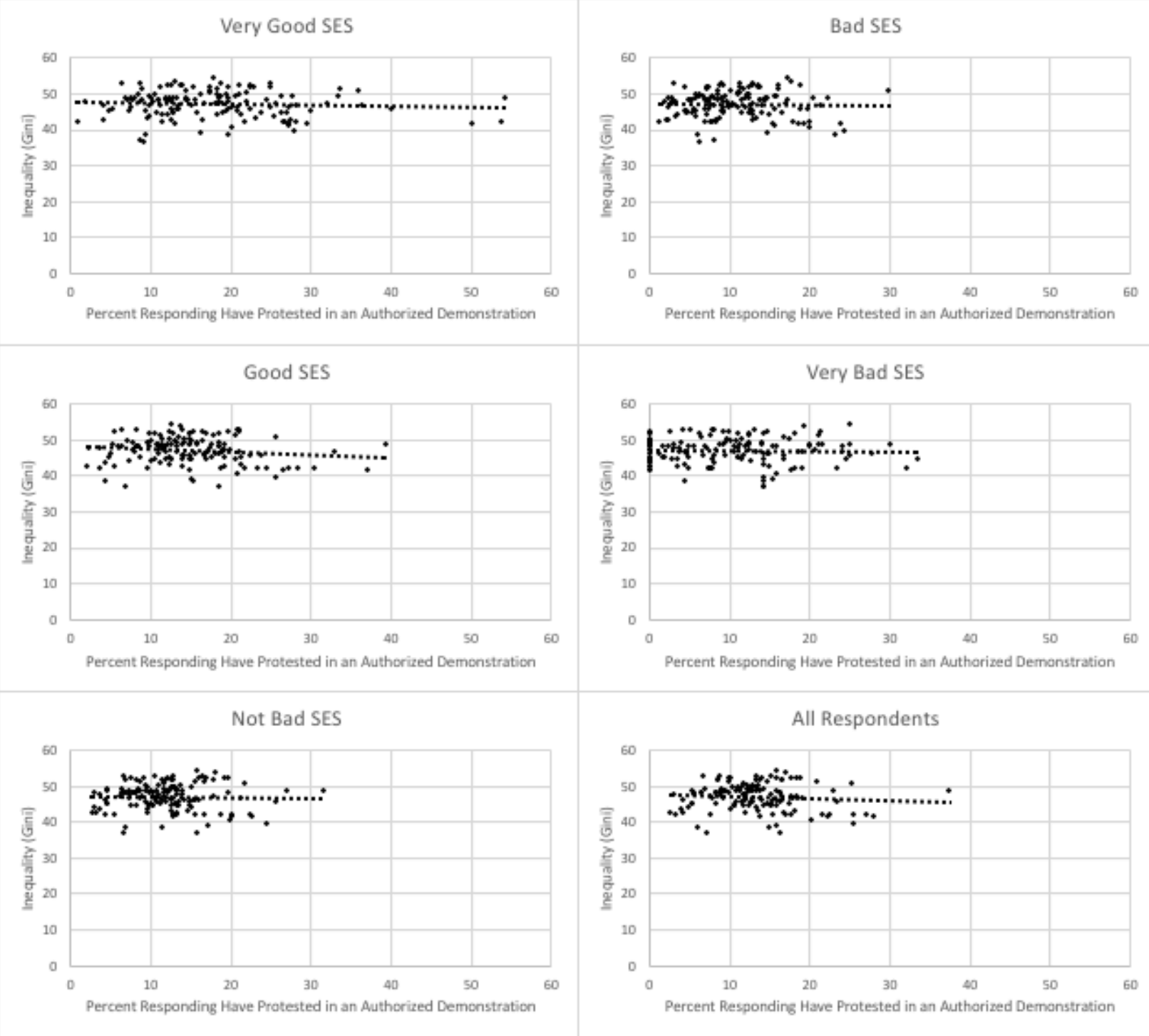


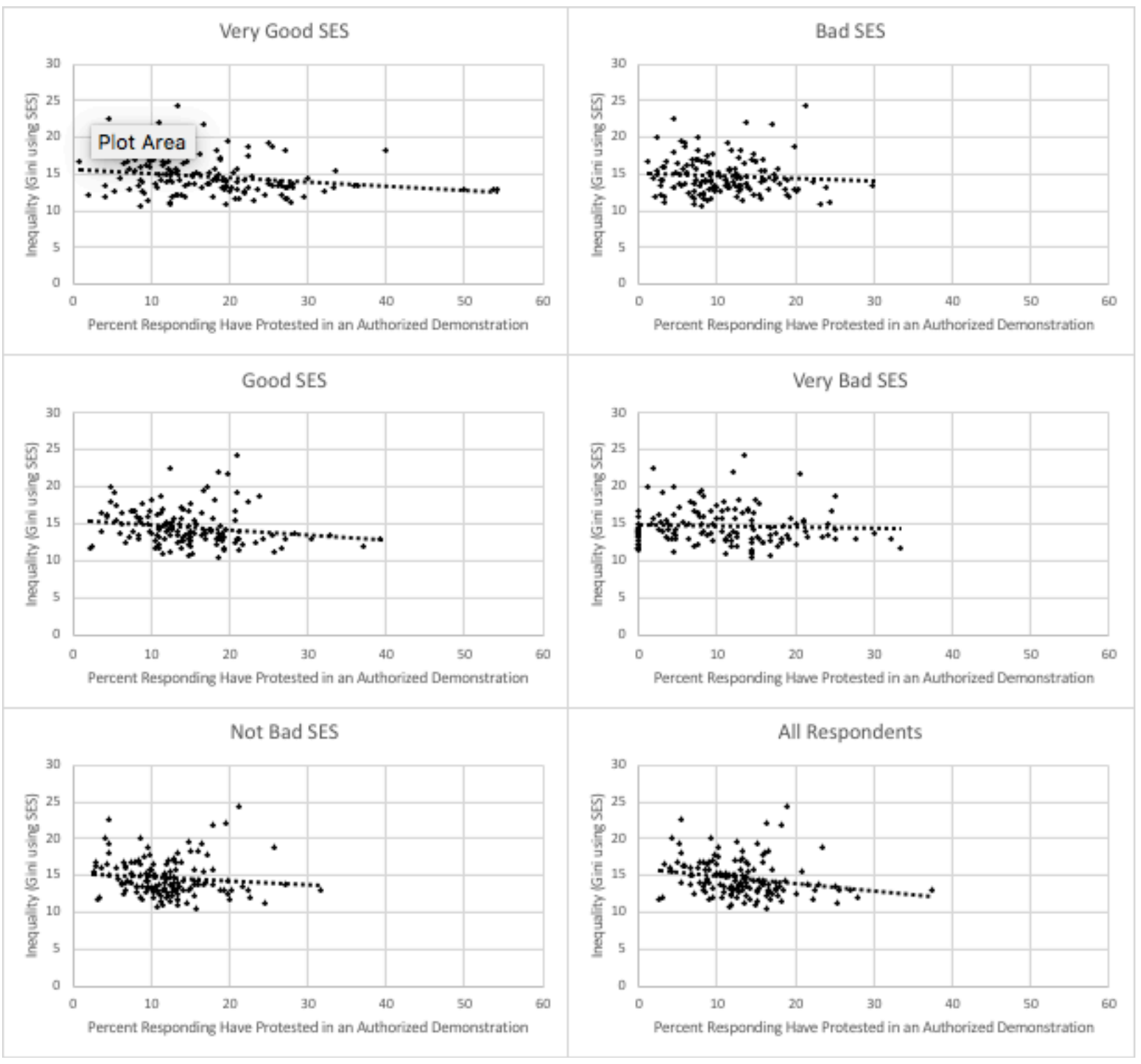


Appendix 12: Percent of each SES category in each country in the Latinobarometer responding they have participated in unauthorized demonstrations
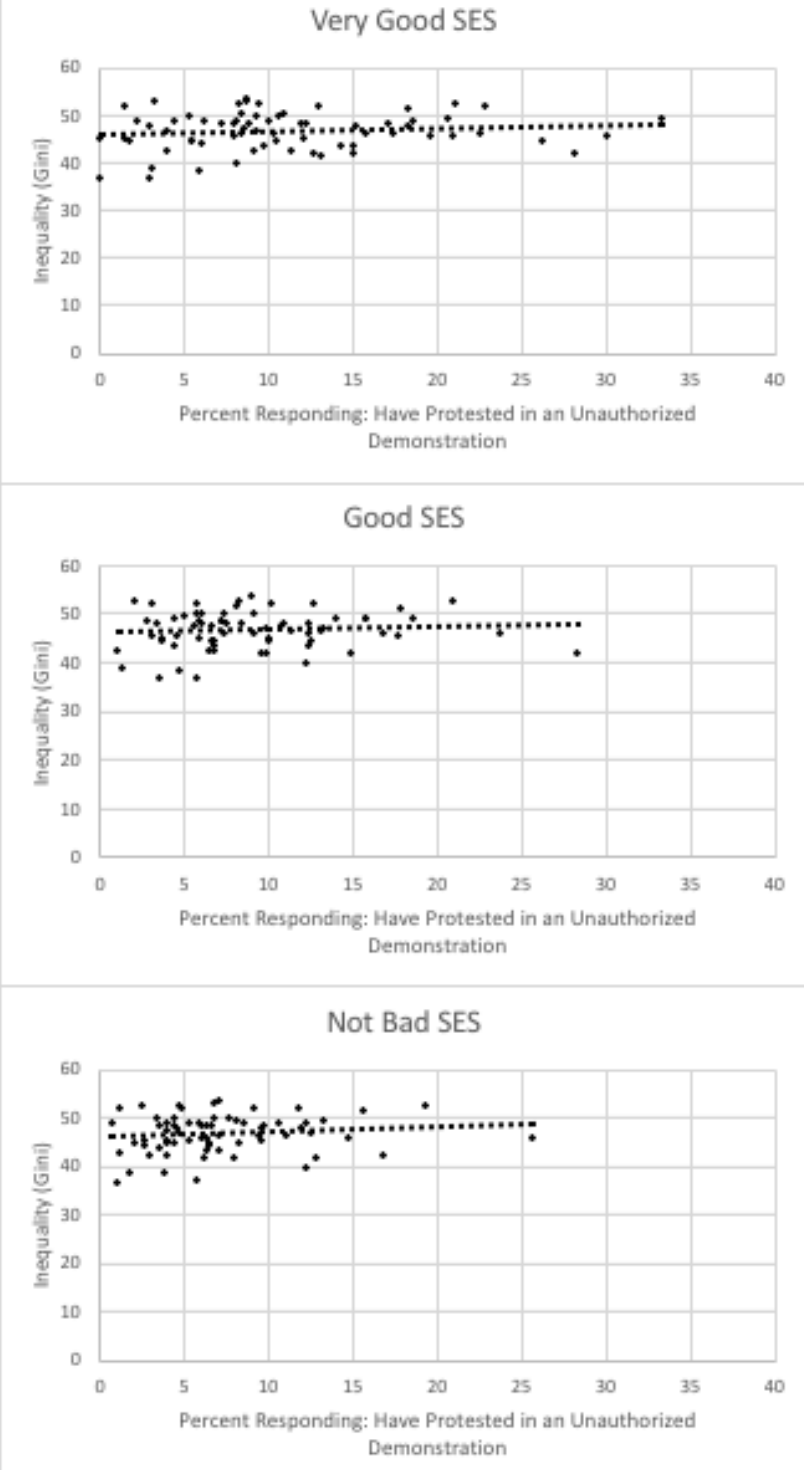

Bad SES

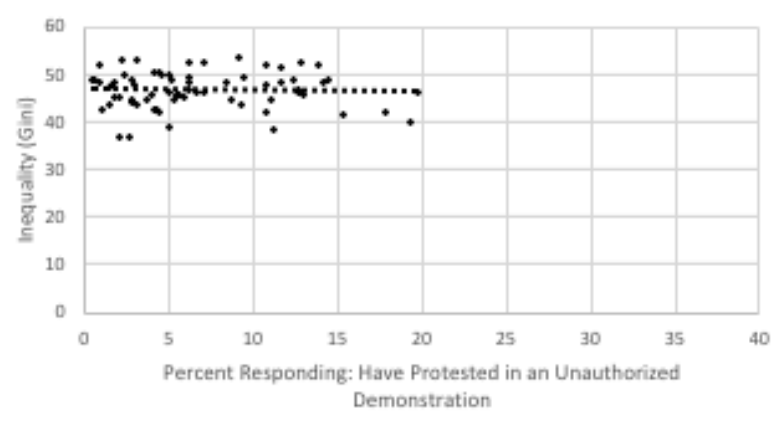

Very Bad SES

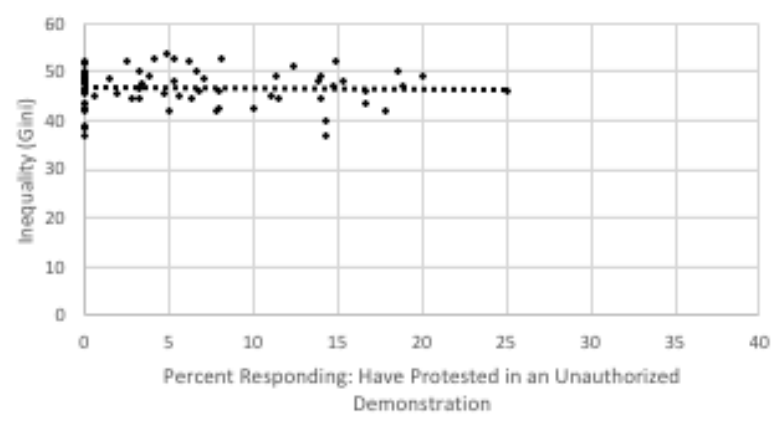

All Respondents

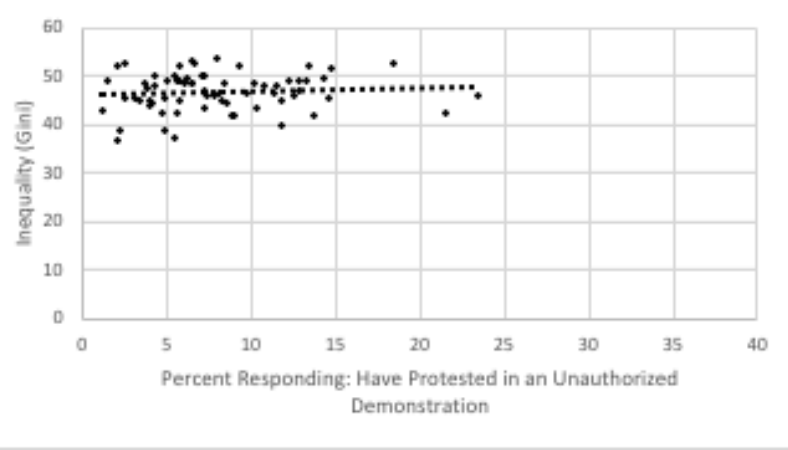




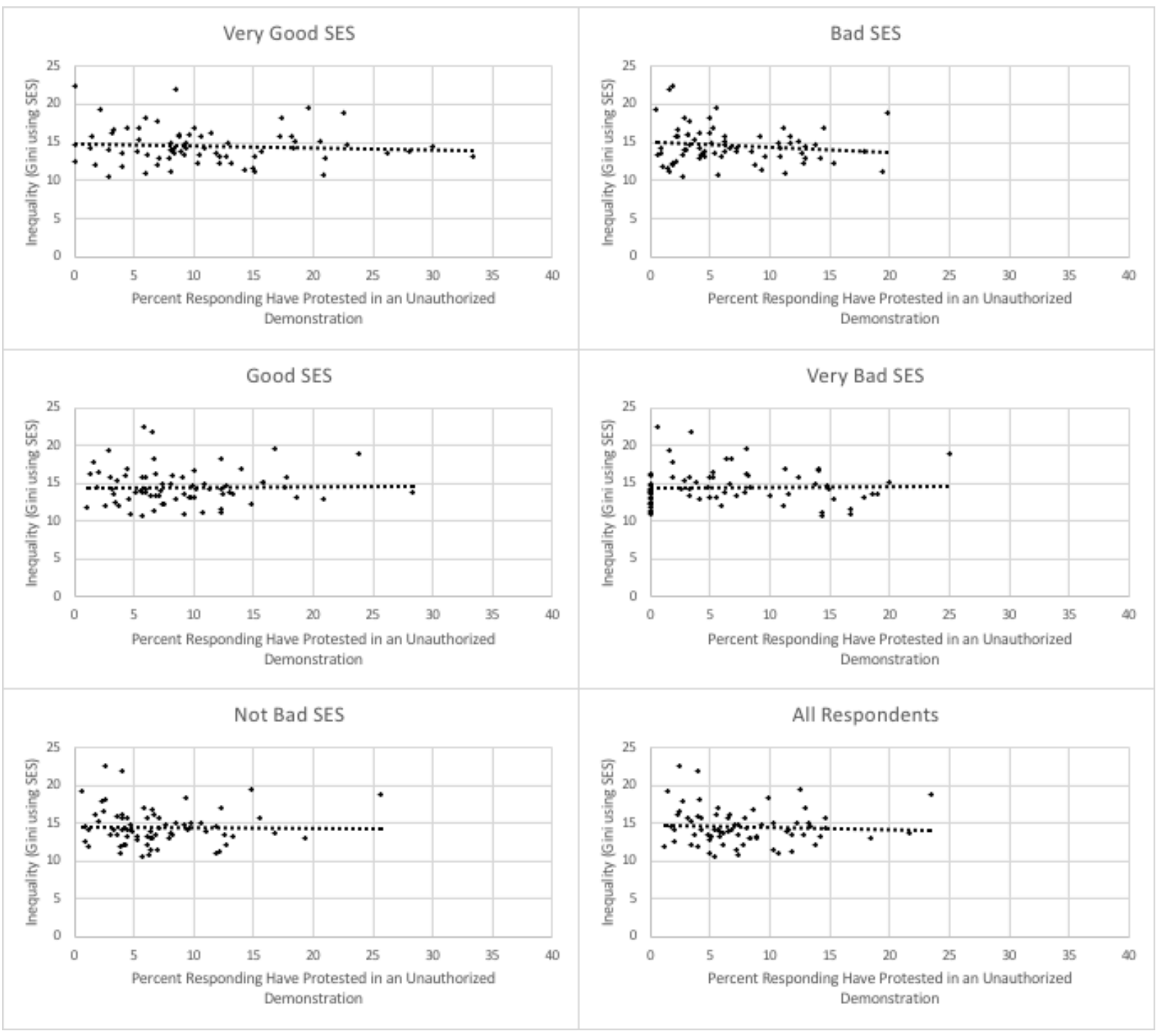




\section{Appendix 13: Percent of each SES category in each country in the Latinobarometer}

responding they have worked for a political party
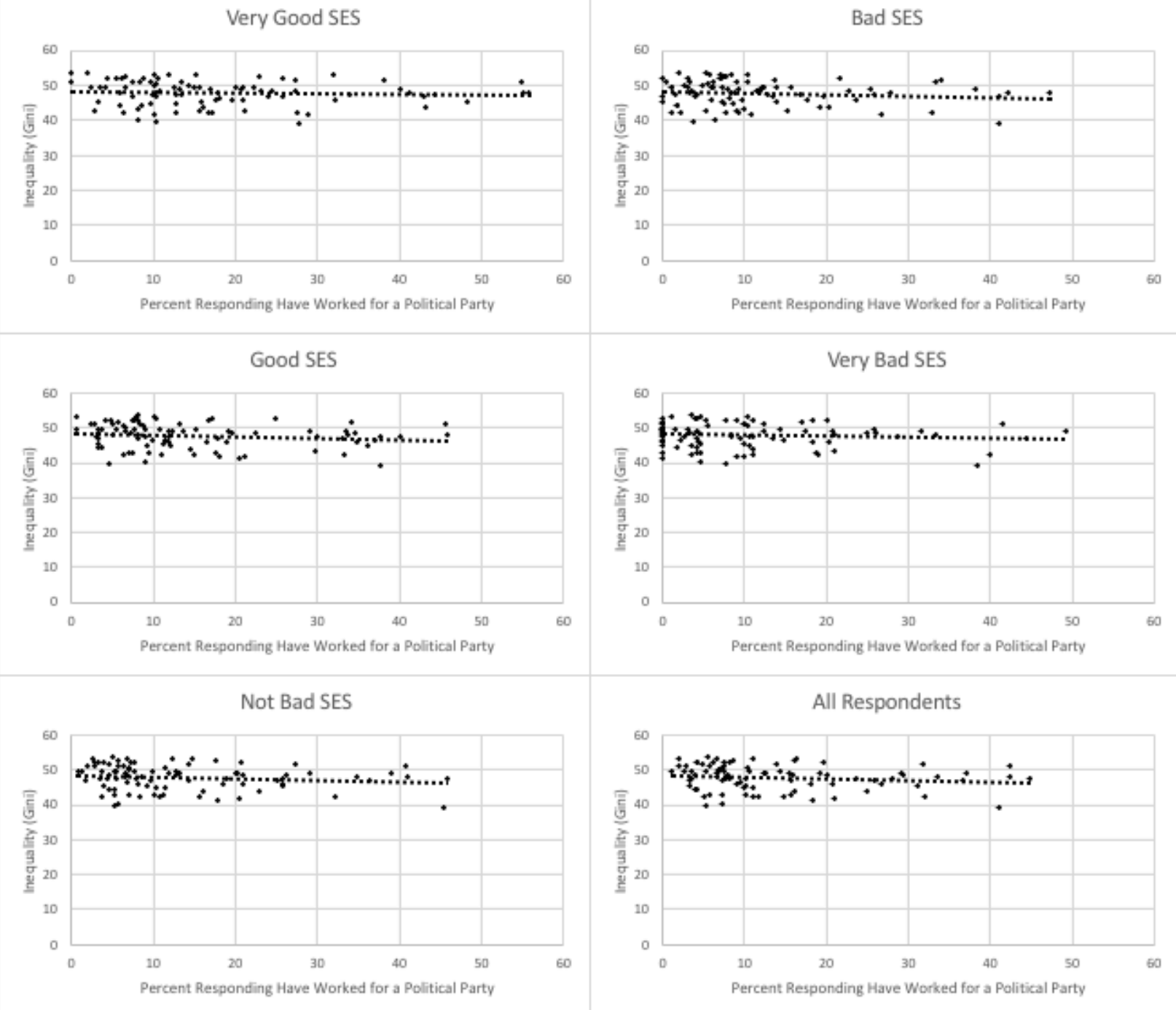


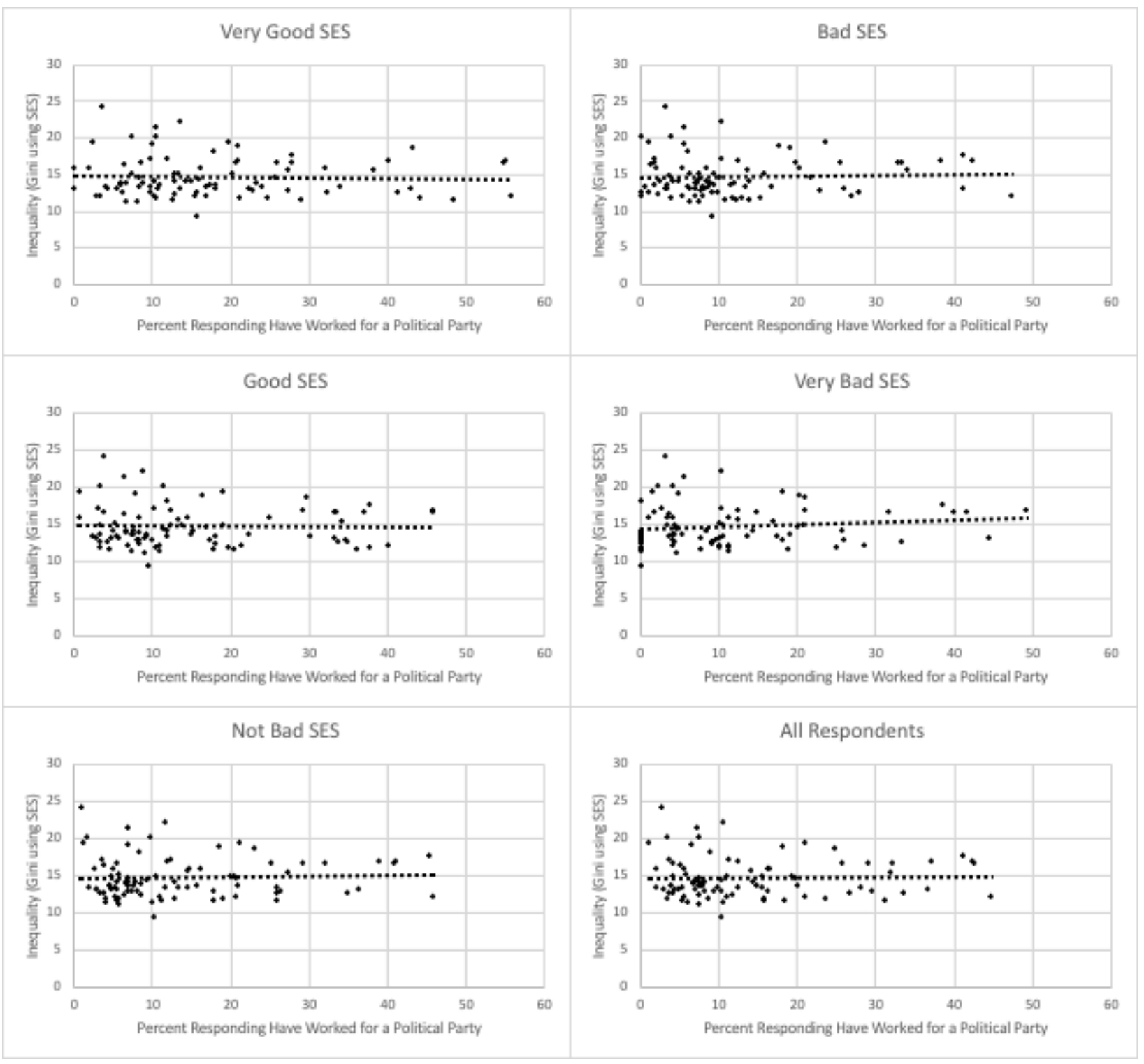


Appendix 14: Percent of each SES category in each country in the Latinobarometer responding they belong to a political party

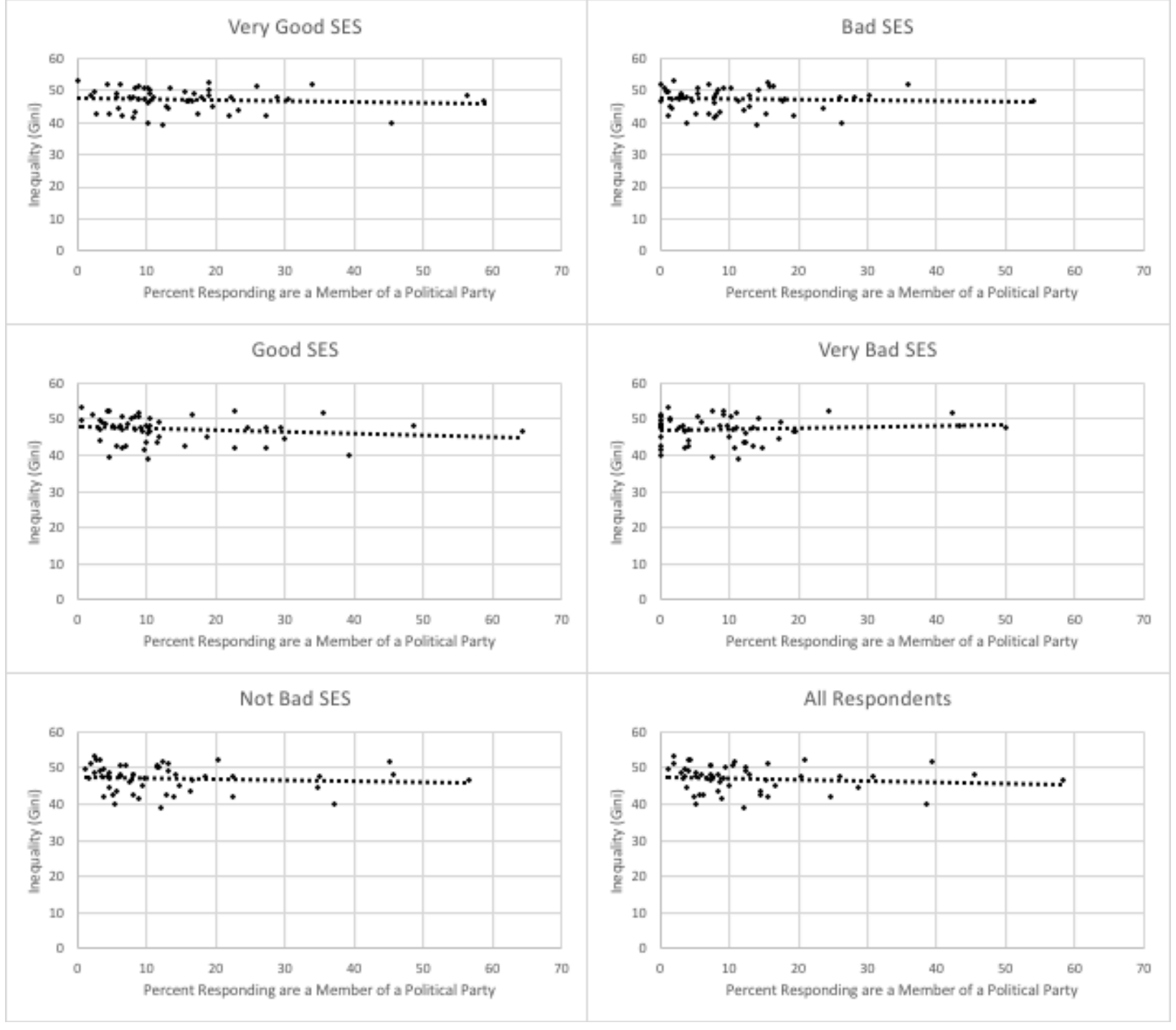




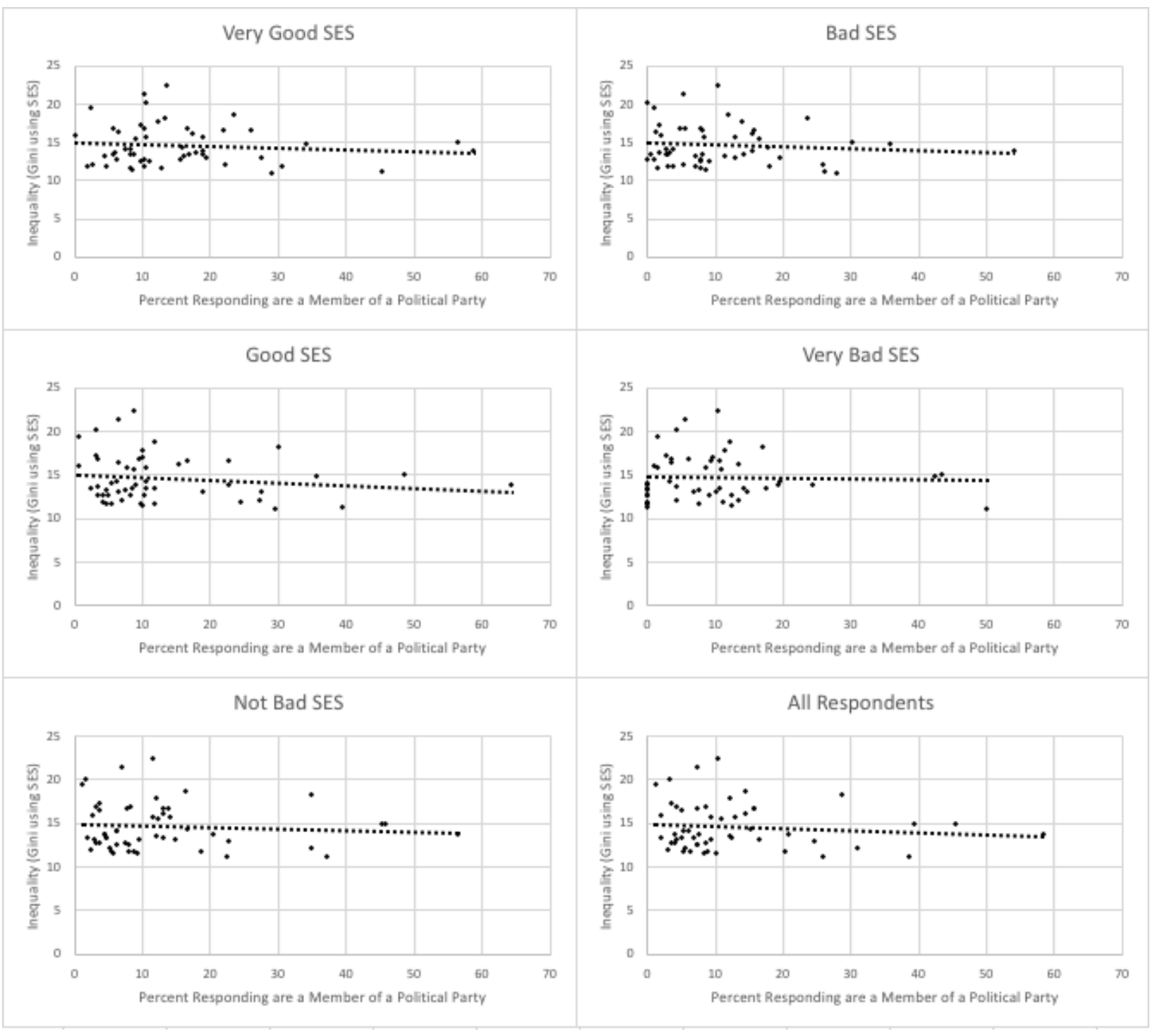




\section{Appendix 15: Percent of each SES category in each country in the Latinobarometer}

responding they belong to a labor union
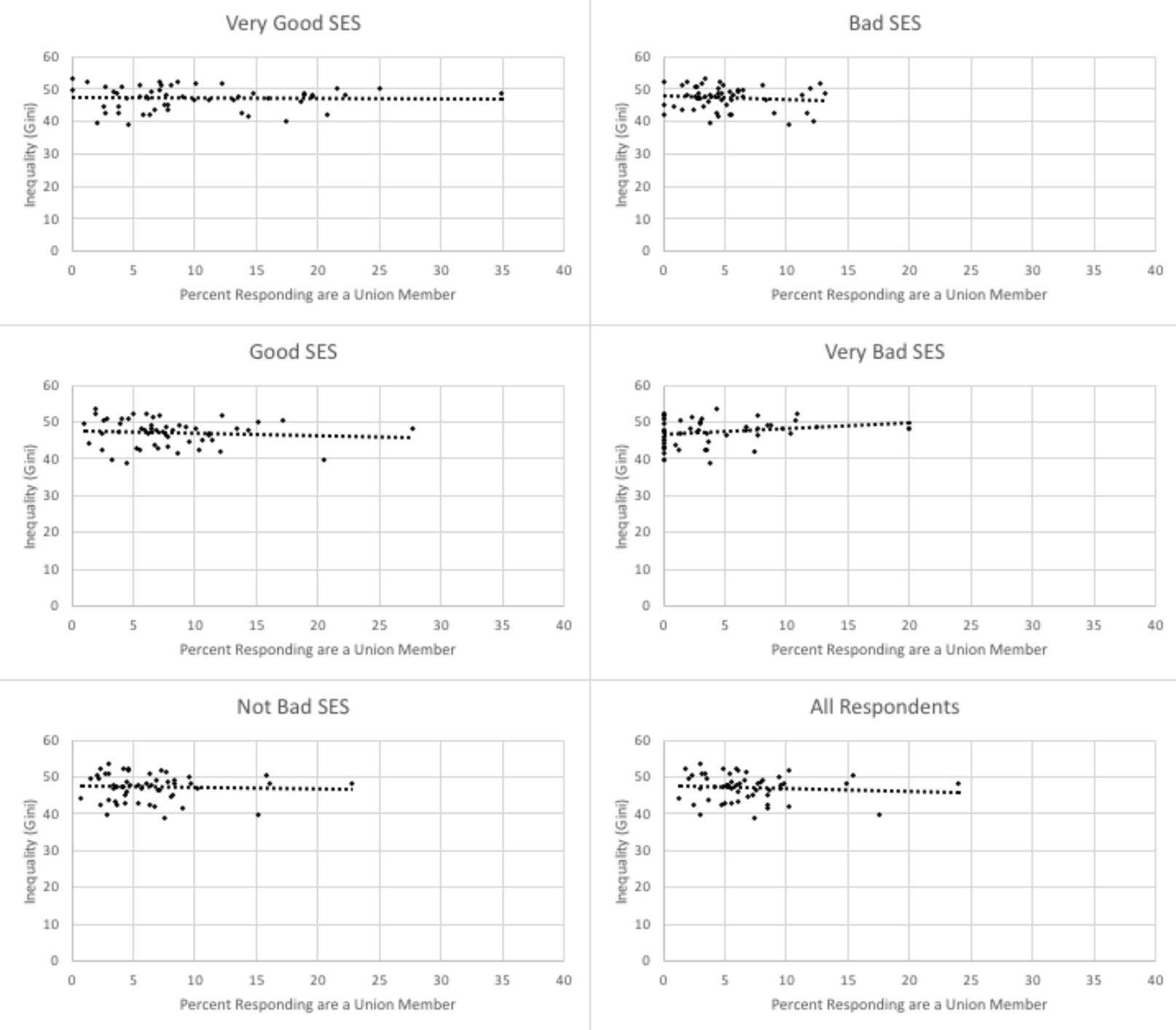


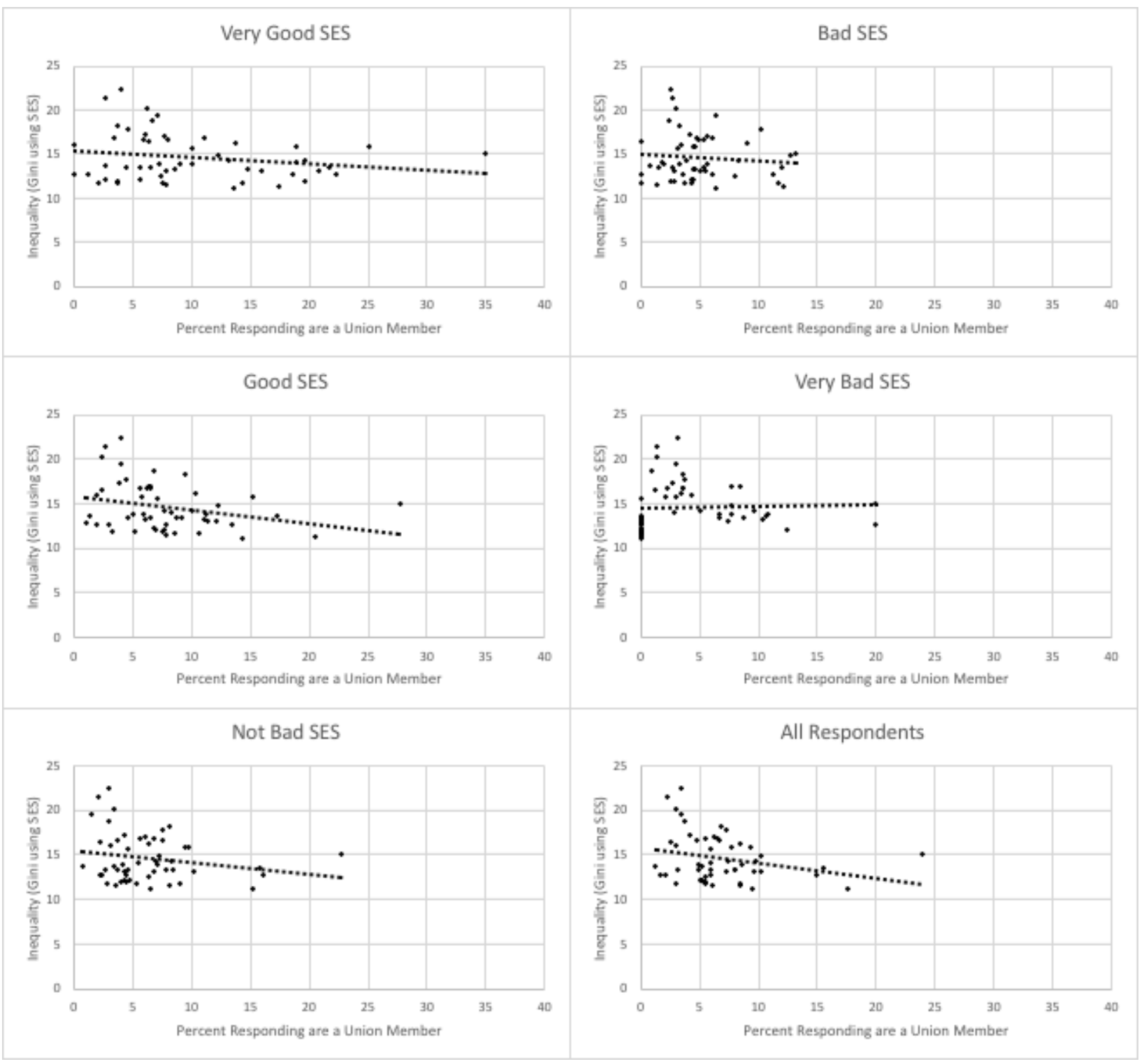


Appendix 16: Percent of each SES category in each country in the Latinobarometer responding they have signed a petition
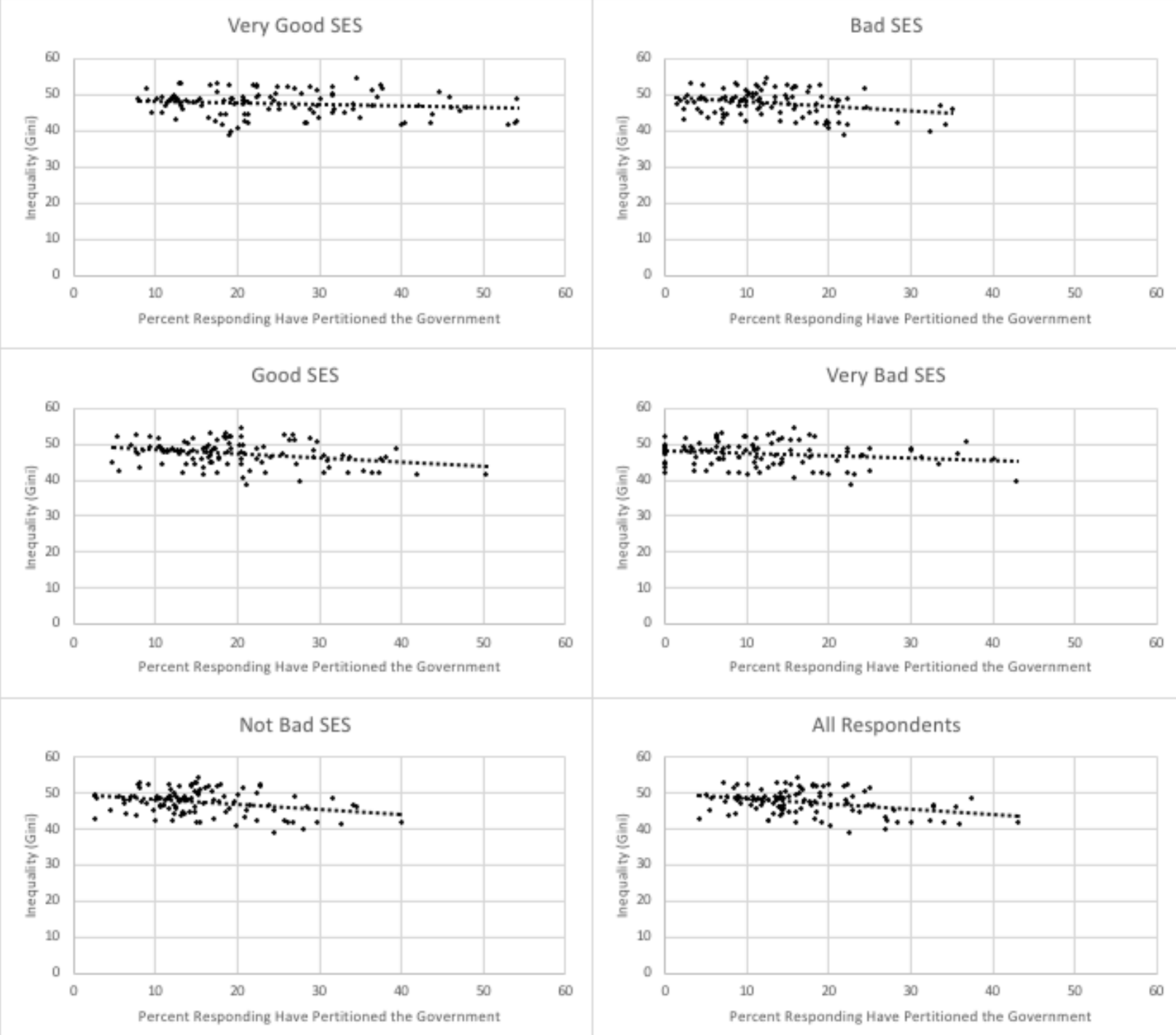


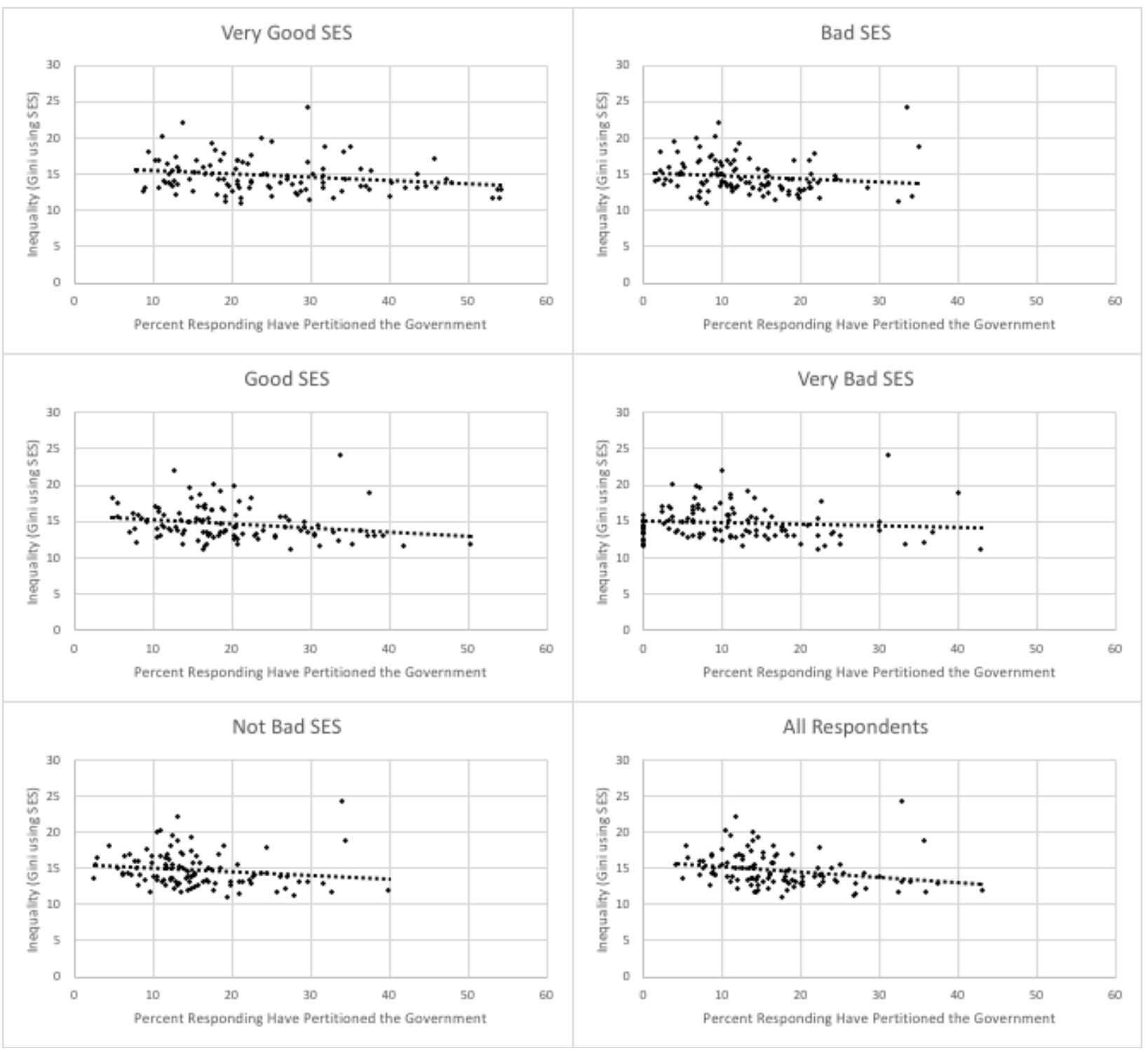




\section{Appendix 17: Percent of each SES category in each country in the Latinobarometer}

responding they have blocked traffic

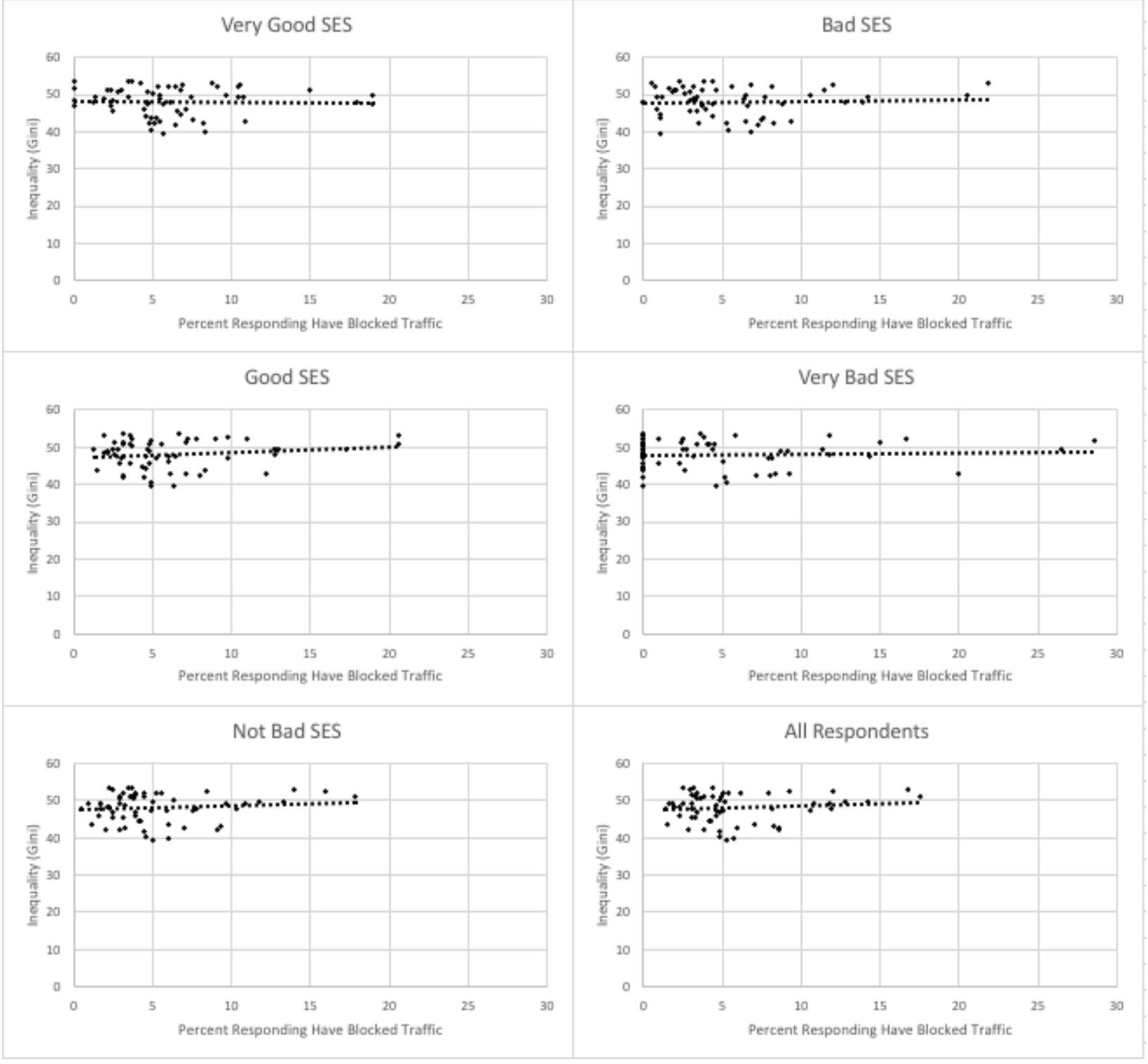




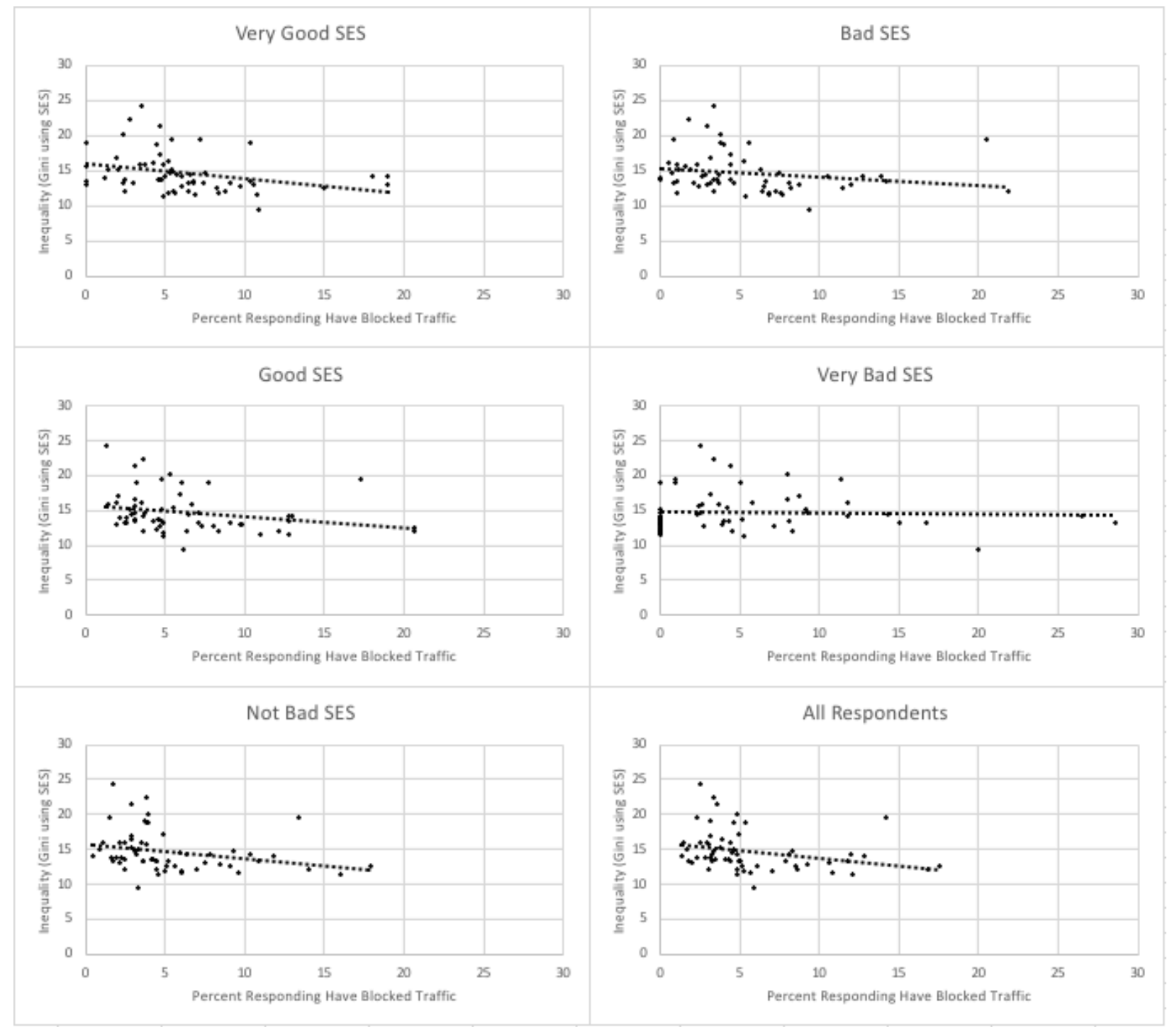


Appendix 18: Percent of each SES category in each country in the Latinobarometer responding they have rioted

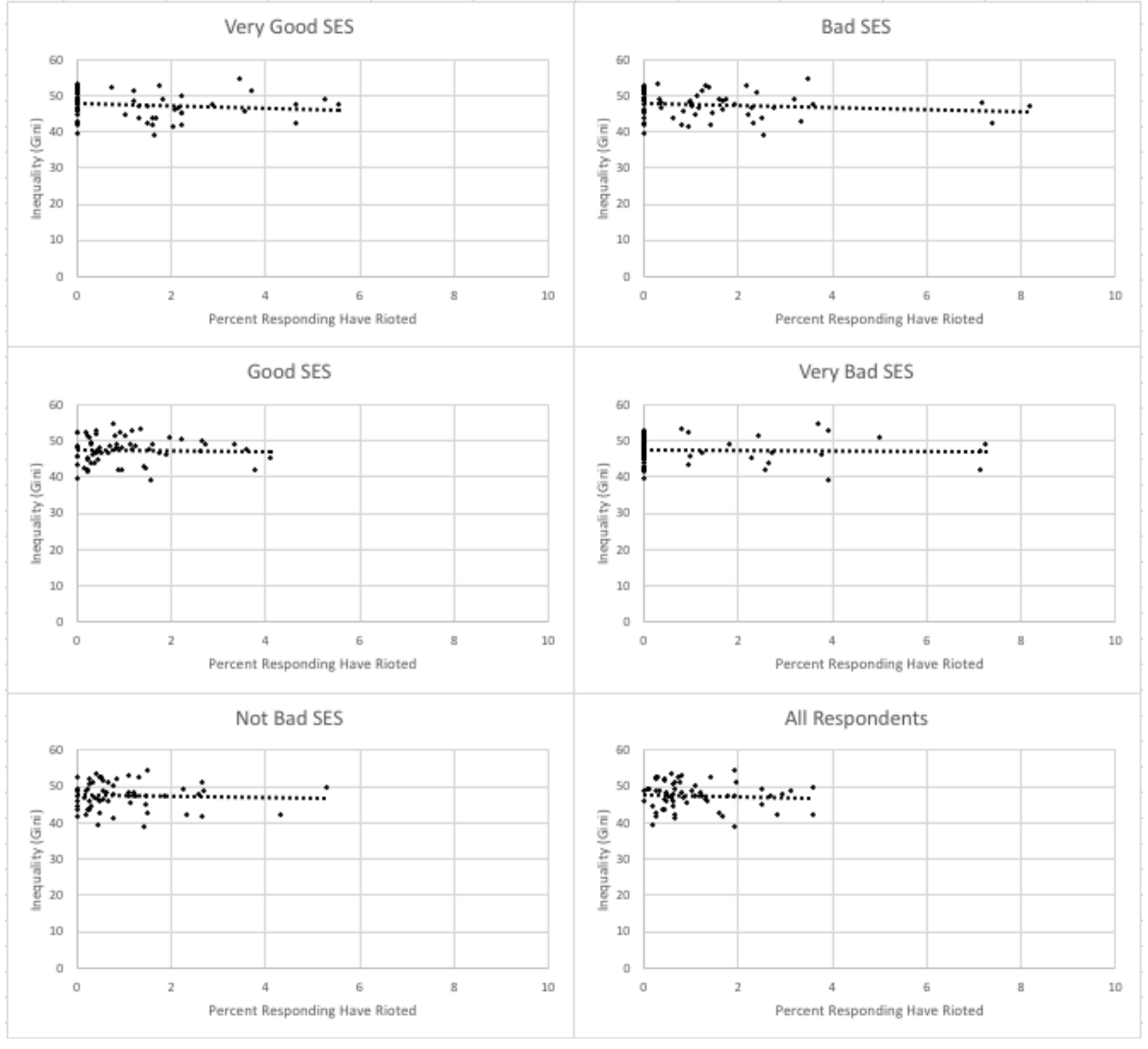



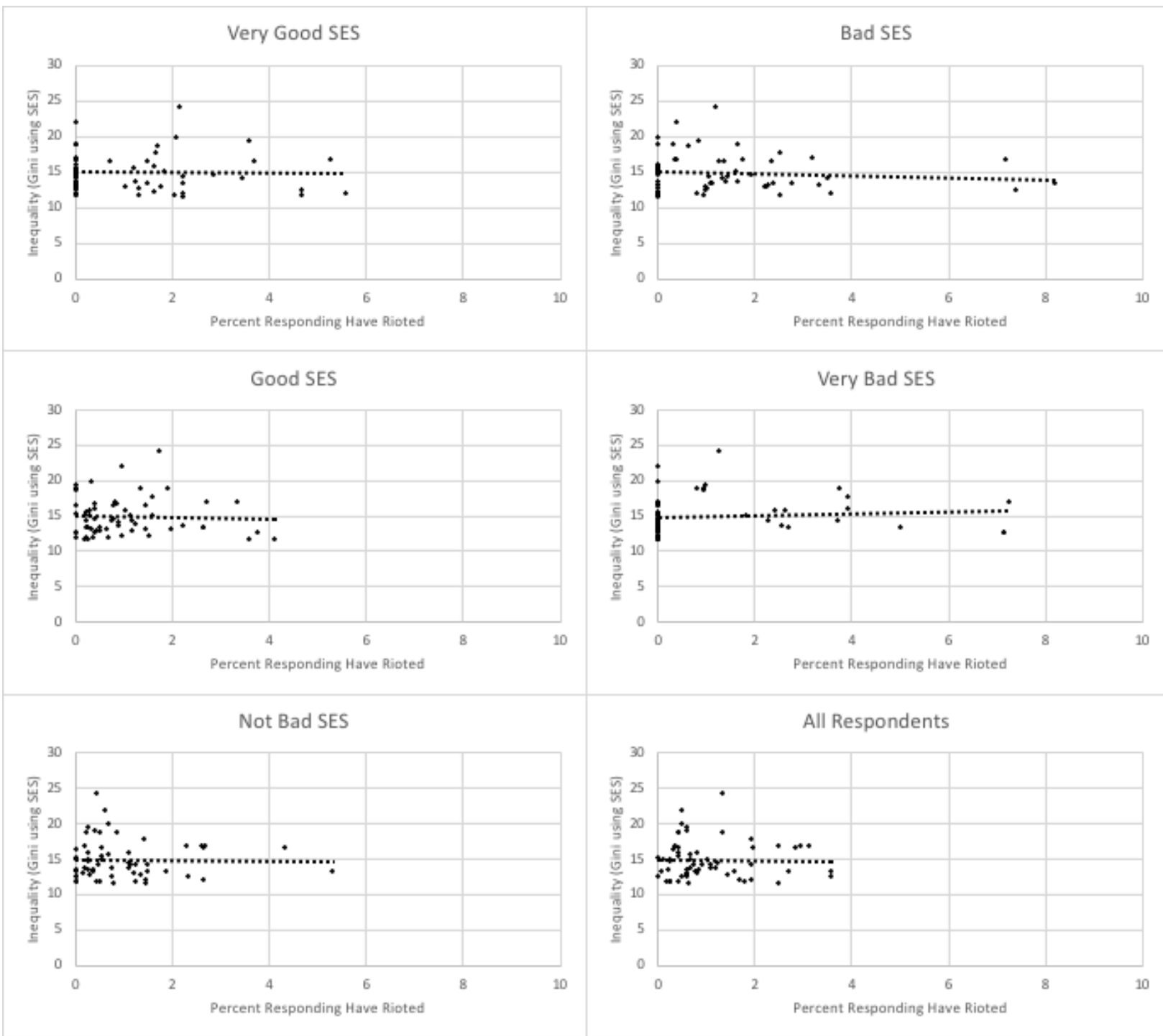
Appendix 19: Percent of each SES category in each country in the Latinobarometer responding they have occupied a building or factory

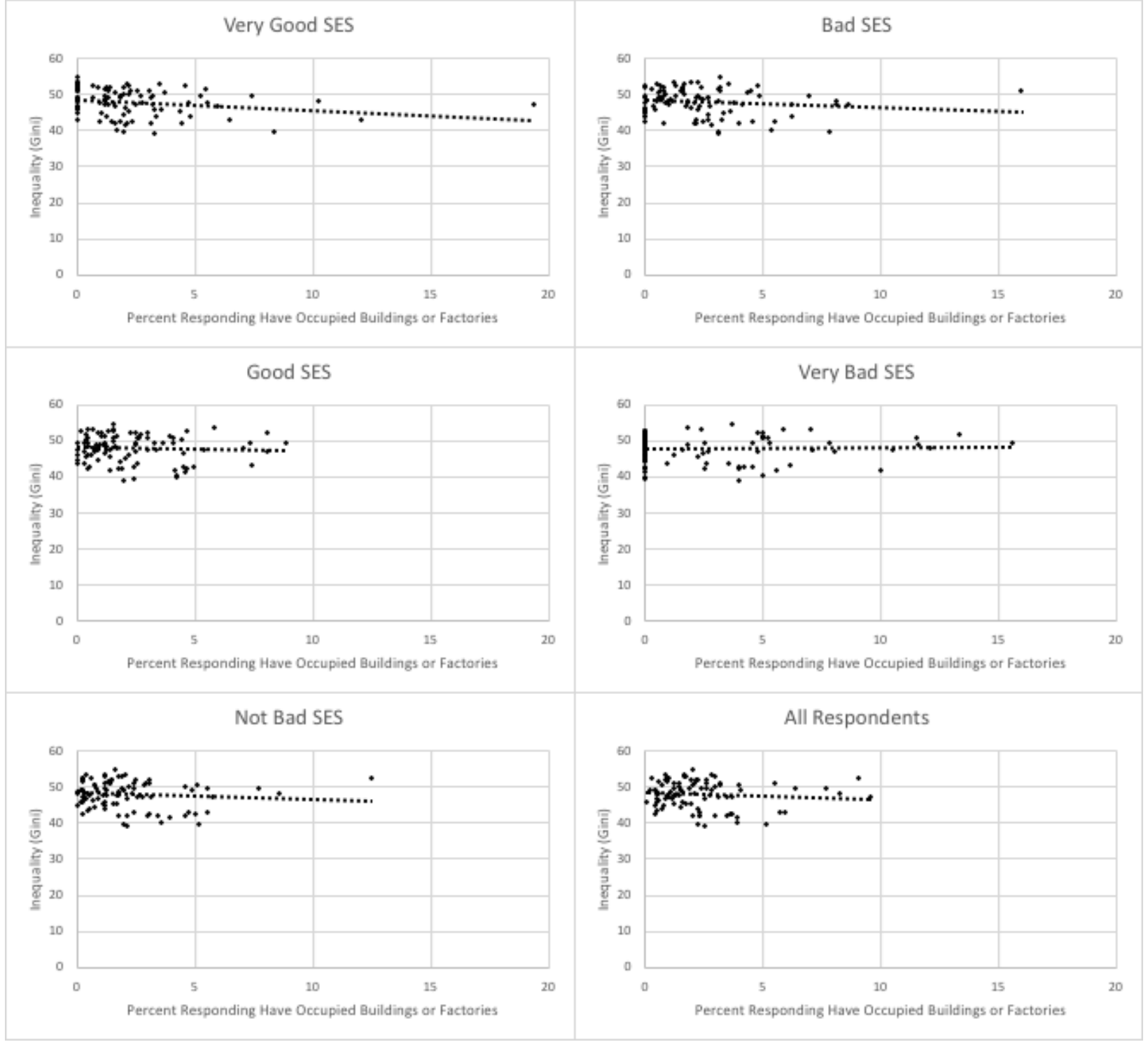




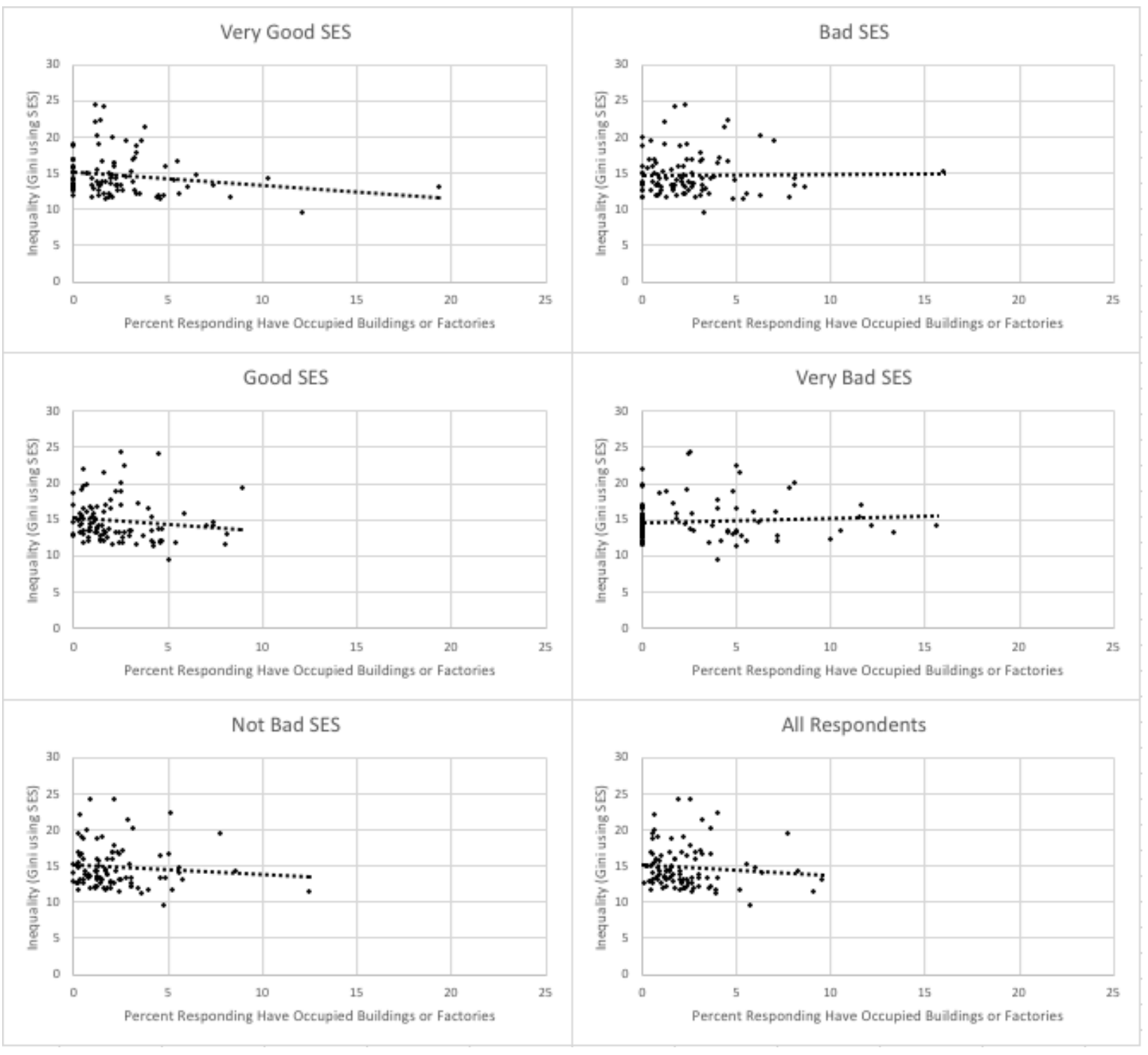


Appendix 20: Percent of each SES category in each country in the Latinobarometer responding unions are one of the three most powerful groups in their country by inequality using Gini using SES as the measure of inequality
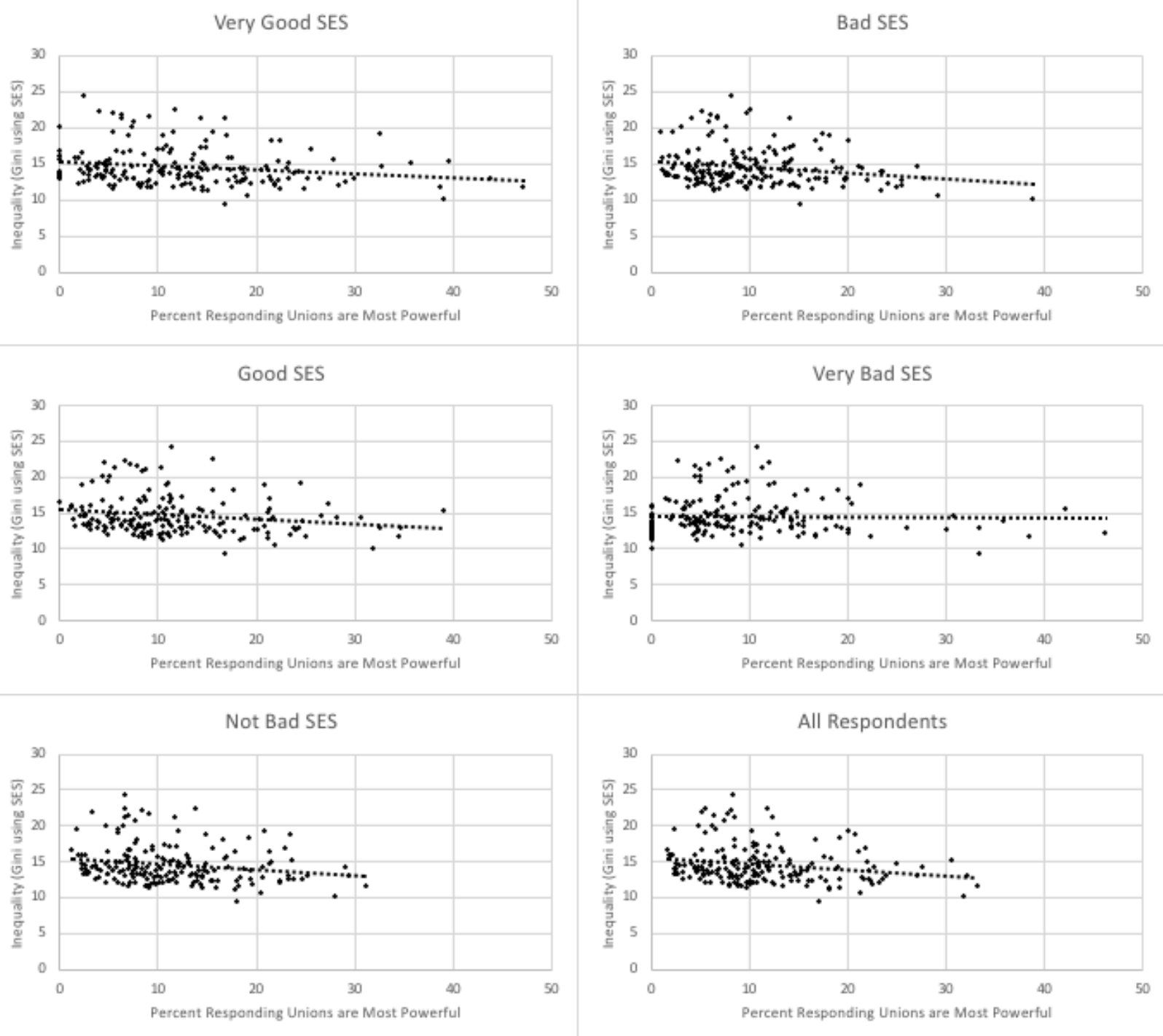
Appendix 21: Percent of each SES category in each country in the Latinobarometer responding businesses are one of the three most powerful groups in their country by inequality using Gini using SES as the measure of inequality
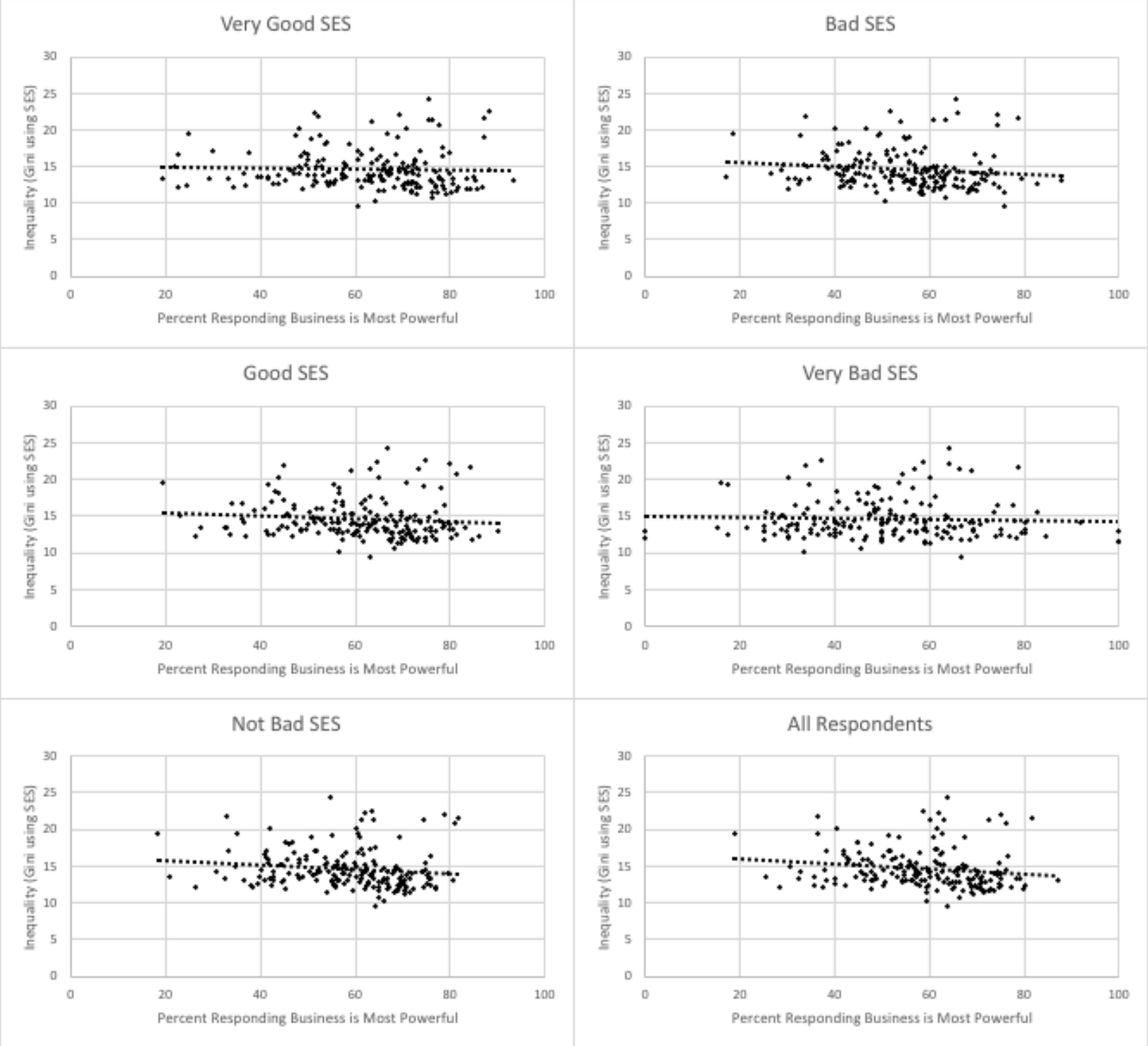


\section{Chapter 6}

\section{Conclusion: Expanding the Scope}

While the results of the two empirical chapters did provide some limited support for my theory, the results also contradicted my theory in places. In the US and Latin American cases, it appears the middle class may have the most influence over trade policy. While the Latin American case does point to those in the middle class having the most influence over policy, it seems as if politicians might actually go against the preferences of the upper middle class. Results are somewhat similar in the American case, the influence of the upper class group decreases with inequality, which was unexpected; also, unexpectedly the influence of the lower middle class increases with inequality. It may be that the middle class is able to have influence due to the combination of a large number of votes and the availability of resources needed to participate. Expectedly, in the American case, those in the lower class appear to have less influence when there is higher inequality, while the results from the Latin American case pointed to the lower class not having influence. It does appear that the lower class becomes more politically active in some ways when inequality increases, but this does not seem to lead to greater influence. The results from the American chapter are interesting, given that those lower down the SES scale appear to participate more in some activities as inequality increases. It could be that the results from the American chapter of the lower middle class having greater influence at higher levels of inequality are a result of them actually participating more in some activities as inequality increases, rather than less as was expected. Furthermore, the results for the wealthy not having influence leaves the possibility that the wealthy's preferences are captured within the preferences of business interest groups, the wealthy being more likely to control business interest groups. 
When it comes to interest groups, the American chapter points to interest groups in favor and against trade policy receiving support for their position from Senators, regardless of the level of inequality. This was not the case for Latin America where the regression results pointed to interest groups not having influence over trade policy. However, the public in Latin America does view the power of businesses increasing as inequality increases, and the power of unions decreasing as inequality increases. These results could be because of the nature of the Latin American interest group system. Many Latin American countries are still developing their interest group systems and therefore it is likely businesses are still able to largely drown out unions.

While these results do provide some information on how inequality effects the influence of interest groups and the public on policy, more exploration is needed to determine what this complex relationship is. This is particularly the case given that the results contradict themselves in places, leaving several questions. First, are the contradictory results due to a low N; second, what role does saliency play, do some groups not have influence because they are not seeking to influence policy; finally, how do the levels of participation of the different class groups and interest groups vary with inequality?

One way to remedy the issue of a low $\mathrm{N}$ is to apply the theory to a greater number of issues. Trade was originally chosen because it affects all people and businesses within a country, but the theory can be applied to other issues, both domestic and international. Doing this will allow for the $\mathrm{N}$ to be increased and provides the additional benefit of examining how the theory applies across multiple types of issues. It may be the case that the theory applies to some issues and does not apply to others, particularly when an issue is salient or not. 
While politicians do have an incentive to abide by the preferences of voters when an issue has low saliency, because of the possibility of the issue becoming salient, politicians have more of an incentive to focus on issues that are currently salient to voters. Politicians know these are the issues voters are likely to hold them accountable for. Measuring saliency will entail determining if voters know how their representatives acted on particular issues and whether or not the respondents' votes for or against their representatives were influenced by how their representatives acted. Expanding the number of issues examined and bringing in a measure of saliency will first be done for the US because of the availability of data from the CCES. Furthermore, there is the availability of data on interest group contributions to politicians, providing a direct measure of interest groups' actions.

Finally, my theory assumes that people's level of participation will change with inequality. The evidence from the Latin American chapter showed this is the case, but not always in the way I expected, with those at the bottom participating less in some activities, but more in others as inequality increases. There are two reasons why this might be the case. Because increasing inequality might not mean those at the bottom are getting poorer, they are only getting relatively poorer. This means those at the bottom still might participate at the same rate as inequality increases because they still have resources needed to participate in ways such as voting or protesting, although their relative ability to give campaign contributions would be diminished. Alternatively, those at the bottom could increasingly participate because they see themselves as becoming relatively more disadvantaged and they see participation in some activities as a way to reverse this. While they could also participate less in other activities because they do not see them as effective. Not only does the participation by those in the lower class change with inequality, so does the participation of other groups. This raises the question 
of how effective each class group is able to be as inequality changes; that is, does their participation actually lead to greater influence? Determining the answer to this question will mean first measuring how participation from each class group varies with inequality, this can also be done for interest groups, and then determining how much their participation is able to influence policy.

In a democracy, representation is, in theory, meant to be equal, with each citizen getting an equal amount; of course, in practice, this is never the case. The extent to which inequality impacts how much representation different people in society receive is the extent to which inequality can start to undermine democracy. When some groups receive outsized representation, they will be able to become entrenched and structure the system so others cannot effectively challenge their power. However, given the results from chapters IV and V it still seems like different class groups within the public compete, but some groups are less competitive than others. In the American case, the lower class appear to have less influence as inequality increases and, in the Latin American case, the public identifies unions as having less power as inequality increases. Influence certainly changes in some cases with inequality and these changes make a democratic government more or less representative. 


\section{References}

Acemoglu, D. 2002. “Technical Change, Inequality, and the Labor Market." Journal of Economic Literature 40: 7-72.

Acemoglu, Daron. 2003. "Patterns of Skill Premia." Review of Economic Studies 70 (2): 199230.

Alvaredo, Facundo, Lucas Chancel, Thomas Piketty, Emmanuel Saez, and Gabriel Zucman. 2018. World Inequality Report. World Inequality Lab.

Alves, Lise. "Presidential Campaign to Cost Nearly R\$1B in Brazil: Daily." The Rio Times 7 July 2014.

Ansolabehere, Stephen, John M. de Figueiredo, and James M. Snyder. 2003. "Why is There so Little Money in U.S. Politics?" The Journal of Economic Perspectives 17 (1): 105-130.

Ansolabehere, Stephen, COOPERATIVE CONGRESSIONAL ELECTION STUDY, 2012: COMMON CONTENT. [Computer File] Release 1: April 15, 2013. Cam- bridge, MA: Harvard University [producer] http://cces.gov.harvard.edu

Ansolabehere, Stephen, COOPERATIVE CONGRESSIONAL ELECTION STUDY, 2006: COMMON CONTENT. [Computer File] Release 3: August 20, 2010. Cambridge, MA: M.I.T. [producer] http://web.mit.edu/polisci/portl/cces/commoncontent.html

Ansolabehere, Stephen, COOPERATIVE CONGRESSIONAL ELECTION STUDY, 2008: COMMON CONTENT. [Computer File] Release 4: July 15, 2011. Cambridge, MA: Harvard University [producer] http://cces.gov.harvard.edu

Arnold, R. Douglas. 1990. The Logic of Congressional Action. New Haven: Yale University Press.

Bailey, Michael, and David W. Brady. 1998. "Heterogeneity and Representation: The Senate and Free Trade." American Journal of Political Science 42 (2): 524-544.

Baker, Andy. 2003. "Why is Trade Reform so Popular in Latin America?: A ConsumptionBased Theory of Trade Policy Preferences." World Politics 55 (3): 423-455.

Balla, Steven J. 2000. "Legislative Success and Failure and Participation in Rule Making." Journal of Public Administration Research and Theory. 10(July): 633-653.

Bartels, Larry M. 2005. "Homer Gets a Tax Cut: Inequality and Public Policy in the American Mind." Perspectives on Politics 3 (1): 15-31.

Bartels, Larry M. 2008. Unequal Democracy. Princeton: Princeton University Press. 
Bawn, Kathleen, Martin Cohen, David Karol, Seth Masket, Hans Noel and John Zaller. 2012. "A Theory of Political Parties: Groups, Policy Demands and Nominations in American Politics." Perspectives on Politics 10 (3): 571-597.

Beaulieu, Eugene, Michael Benarroch, and James D. Gaisford. 2011. "Intra-industry Trade Liberalization: Why Skilled Workers are More Likely to Support Free Trade." Review of International Economics 19 (3): 579-594.

Beaulieu, Eugene, Ravindra A. Yatawara, and Wei Guo Wang. 2005. "Who Supports Free Trade in Latin America." The World Economy 28 (7): 941-958.

Berman, Eli, John Bound, and Stephen Machin. 1998. "Implications of Skill-Biased Technological Change: International Evidence." The Quarterly Journal of Economics 113 (4): 1245-1279.

Boehmke, Frederick J., and Daniel C. Bowen. 2010. "Direct Democracy and Individual Interest Group Membership.” Journal of Politics 72 (3): 659-671.

Brady, Henry E. Sidney Verba, and Kay Lehman Scholzman. 1995. "Beyond SES: A Resource Model of Political Participation.” The American Political Science Review 89 (2): 271294.

Broadband Commission for Sustainable Development. 2016. "The State of Broadband: Broadband Catalyzing Sustainable Development." International Telecommunication Union and United Nations Educational, Scientific and Cultural Organization.

Broockman, David E., and Christopher Skovron. 2014. "What Politicians Believe About Their Constituents: Asymmetric Misperceptions and Prospects for Constituency Control." Prepared for presentation at "Political Representation: Fifty Years After Miller and Stokes," Vanderbilt University, March 1-2, 2013.

Bueno de Mesquita, Bruce, Alastair Smith, Randolph M. Siverson, and James D. Marrow. 2003. The Logic of Political Survival. Cambridge: MIT Press.

Bull, Benedicte. 2014. "The Development of Business Associations in Central America: The Role of International Actors and Economic Integration." Journal of Public Affairs 14 (3): 331-345.

Burkhauser, Richard V. 1996. Income Mobility \& the Middle Class. Washington DC: AEI Press.

Burris, Val. 2005. "Interlocking Directorates and Political Cohesion among Corporate Elites." American Journal of Sociology 111 (1): 249-283. 
Camerra-Rowe, Pamela G. 2004. "Germany, Austria, Switzerland, and the Benelux Countries." In Research Guide to U.S. and International Interest Groups, ed. Clive S. Thomas. Westport, CT: Praeger, 303-305.

Campbell, Andrea Louise. 2002. "Self-Interest, Social Security, and the Distinctive Participation Patterns of Senior Citizens." The American Political Science Review 96 (3): 565-574.

Campbell, David E and Christina Wolbrecht. 2006. "See Jane Run? Women Politicians as Role Models for Adolescents." The Journal of Politics 68 (2): 233-247.

Campos, Nauro F., and Francesco Giovannoni. "Lobbying, Corruption, and Political Influence." Public Choice 131: 1-21.

Carnes, Nicholas. 2012. "Does the Numerical Underrepresentation of the Working Class in Congress Matter?" Legislative Studies Quarterly 37 (1): 5-34.

Carnoy, Martin. 1984. The State and Political Theory. Princeton: Princeton University Press.

Cárdenas, Mauricio. 2010. "State Capacity in Latin America.” Economia 10 (2): 1-45.

Casas-Zamora, Kevin, and Daniel Zovatto. 2016. The Cost of Democracy: Essays on Political Finance in Latin America (Charles Roberts, Trans.). International Institute for Democracy and Electoral Assistance, Organization of American States, Inter-American Dialogue.

Cashell, B. W. (2007). Who are the "middle class"? (RS22627). Washington, DC: Congressional Research Service. http://digitalcommons.ilr.cornell.edu/crs/34/

Center for Responsive Politics. 2016. https://www.OpenSecrets.org/lobby/

Cogburn, Derrick L. and Fatima K. Espinoza-Vasques. 2011. "From Networked Nominee to Networked Nation: Examining the Impact of Web 2.0 and Social Media on Political Participation and Civic Engagement in the 2008 Obama Campaign. Journal of Political Marketing 10: 189-213.

Coleman, James S. 1988. "Social Capital in the Creation of Human Capital." American Journal of Sociology 94: S95-S120.

Cunningham, Jennifer, and Michael K. Moore. 1997. "Elite and Mass Foreign Policy Opinions: Who is Leading this Parade?" Social Science Quarterly 78 (3): 641-656.

Dagher, Veronica. 2016. "What are the Top Concerns Among the Ultra Wealthy." Wall Street Journal. http://www.wsj.com/podcasts/what-are-the-top-concerns-among-the-ultrawealthy/CC009599-D77F-4224-9637-4E718DEBC0B1.html) 
Davies, Hugh, and Heather Joshi. 2002. "Gender and Income Inequality in the UK 1968-90: The Feminization of Earning or of Poverty?" Journal of the Royal Statistical Society: Statistics in Society, Series A 161 (1): 33-61.

Djerdjian, Daron O. 2010. "Economics Versus Politics in Trade Policy." Review of World Economies 146 (2): 223-240.

Dodd, Lawrence. 1977. "Congress and the quest for power." In Congress Reconsidered, eds. Dodd and Bruce Oppenheimer. Washington: CQ Press.

Dos Santos, Luiz Alberto, and Paulo Mauricio Teixeira da Costa. 2014. "The Contribution of Lobby Regulation Initiatives in Addressing Political Corruption in Latin America." Journal of Public Affairs 14 (3): 379-391.

Downs, Anthony. 1957. An Economic Theory of Democracy. New York: HarperCollins Publishers.

Duch, Raymond M, and Randy Stevenson. 2010. "The Global Economy, Competency, and the Economic Vote." The Journal of Politics 72 (1): 105-123.

Dugan, Andrew. 2015. "Majority of Americans See Congress as Out of Touch, Corrupt." Gallup. http://www.gallup.com/poll/185918/majority-americans-congress-touchcorrupt.aspx. 2 March 2016.

Dutt, Pushan and Devashish Mitra. 2002. "Endogenous Trade Policy Through Majority Voting: An Empirical Investigation." Journal of International Economics 58: 107-133.

Dutt, Pushan and Devashish Mitra. 2006. "Labor Versus Capital in Trade-Policy: The Role of Ideology and Inequality." Journal of International Economics 69: 310-320.

Duvanova, Dinissa. 2007. "Bureaucratic Corruption and Collective Action: Business Associations in the Postcommunist Transition." Comparative Politics 39 (4): 441-461.

Edling, Christofer R., Gergei M Farkas, and Jens Rydgren. 2015. "Integration of the Swedish Local Elite: The Role of Professional and Private Networks." Scandinavian Political Studies 38 (1): 49-74.

Ehrlich, Sean D. 2007. "Access to Protection: Domestic Institutions and Trade Policy in Democracies." International Organization 61 (3): 571-605.

Ehrlich, Sean D. 2011. Access Points: An Institutional Theory of Policy Bias and Policy Complexity. Oxford: Oxford University Press.

Ehrlich, Sean D. 2018. The Politics of Fair Trade: Moving Beyond Free Trade \& Protection. New York: Oxford University Press. 
Eisenhauer, Joseph G. 2008. "An Economic Definition of the Middle Class." Forum for Social Economics 37 (2): 103-113.

Ellison, Nicole B, Charles Steinfield, and Cliff Lampe. 2007. "The Benefits of Facebook "Friends:" Social Capital and College Students' Use of Online Social Network Sites." Journal of Computer-Mediated Communication 12: 1143: 1168.

Eveland, W. P. Jr. 2004. "The Effect of Political Discussion in Producing Informed Citizens: The Roles of Motivation, Information, and Elaboration.” Political Communication 21 (2): 177-93.

Ezrow, Lawrence, and Timothy Hellwig. 2014. "Responding to Voters or Responding to Markets? Political Parties and Public Opinion in an Era of Globalization." International Studies Quarterly 58 (4): 816-827.

Fattore, Christina. 2012. "Interest Group Influence on WTO Dispute Behaviour: A Test of State Commitment." World Trade 46 (6): 1261-1280.

Field G. Lowell, and John Higley. 1980. Elitism. Boston: Routledge.

Fordham, Benjamin O., and Timothy J. McKeown. 2003. "Selection and Influence: Interest Groups and Congressional Voting on Trade Policy." International Organizations 55: 519-549.

Fulton, Sarah A. 2012. "Running Backwards and in High Heels" Political Research Quarterly 65(2): 303-314.

Gainous, Jason, Adam David Marlowe, and Kevin M. Wagner. "Traditional Cleavages or a New World: Does Online Social Networking Bridge the Political Participation Divide?" International Journal of Politics, Culture, and Society 26 (2): 145-158.

Gallego, Aina. 2010. "Understanding Unequal Turnout: Education and Voting in Comparative Perspective.” Electoral Studies 29: 239-248.

Garner, Bob. 2012. Bob Garner's Book of Barbecue: North Carolina's Favorite Food. Winston-Salem: John F. Blair Publisher.

Gerber, Alan S., Gregory A. Huber, David Doherty, Conor M Dowling. 2012. "Disagreement and the Avoidance of Political Discussion: Aggregate Relationships and Differences across Personality Traits." American Journal of Political Science 56 (4): 849-874.

Gilens, Martin. 2005. "Inequality and Democratic Responsiveness." Public Opinion Quarterly 69 (5): 778-796.

Gilens, Martin. 2009. "Preference Gaps and Inequality in Representation." Political Science and Politics 42 (2): 335-341. 
Gilens, Martin and Benjamin I. Page. 2014. "Testing Theories of American Politics: Elites, Interest Groups, and Average Citizens." Perspectives on Politics 12 (3): 564-581.

Gimpelson, Vladimir and Treisman, Daniel, Misperceiving Inequality. IZA Discussion Paper No. 9100 . Available at SSRN: https://ssrn.com/abstract=2655048.

Goodin, Robert, and John Dryzek. 1980. "Rational Participation: The Politics of Relative Power." The British Journal of Political Science 10 (3): 273-292.

Gerber, Alan S., Gregory A. Huber, David Doherty, Conor M. Dowling. 2012. "Disagreement and the Avoidance of Political Discussion: Aggregate Relationships and Differences across Personality Traits." American Journal of Political Science 56 (4): 849-874.

Gramsci, Antonio. 1989. Selections from the Prison Notebooks. Eds. and Trans. Quintin Hoare and Geoffrey Nowellsmith. International Publishers Co. (Original work

Published 1971)

Greenwood, Justin. 2004. "Interest Representation in the European Union." In Research Guide to U.S. and International Interest Groups, ed. Clive S. Thomas. Westport, CT: Praeger, 309-311.

Gregorio, José de, and Jong-Wha Lee. 2002. "Education and Income Inequality: New Evidence From Cross-Country Data." Review of Income and Wealth 48 (3): 395-416.

Grødeland, Åse. 2006. "Informality, Corruption and Public Procurement in the Czech Republic, Slovenia, Bulgaria and Romania." In Informal Networks and Political Corruption in Post-Socialist Societies, ed. J. Kusner. Koszalin Institute of Comparative European Studies: Koszalin, 25-36.

Grossman, Gene M. and Elhanan Helpman. 2001. Special Interest Politics. Cambridge, MA: The MIT Press.

Grossman, Gene M. and Elhanan Helpman. 2002. Interest Groups and Trade Policy. Princeton: Princeton University Press.

Guisinger, Alexandra. 2009. "Determining Trade Policy: Do Voters Hold Politicians Accountable?" International Organization 63 (3): 533-557.

Habib, Adam, and Hermien Kotzé. 2003. "Civil Society, Governance and Development in an Era of Globalization: The South African Case." In Governance in the New South Africa, eds. Guy Mhone, and Omano Edigheji. University of Cape Town Press: Cape Town.

Hacker, Jacob S. and Paul Pierson. 2005. "Abandoning the Middle: The Bush Tax Cuts and the Limits of Democratic Control. Perspectives on Politics 3 (1): 33-53. 
Hacker, Jacob S., and Paul Pierson. 2010. "Winner-Take-All Politics: Public Policy, Political Organization, and the Precipitous Rise of Top Incomes in the United States." Politics \& Society 38 (2): 152-204.

Hainmueller, Jens and Michael Hiscox. 2006. "Learning to Love Globalization: Education and Individual Attitudes Towards International Trade." International Organization 60 (2): 469-498.

Hellwig, Timothy T. 2001. "Interdependence, Government Constraints, and Economic Voting." The Journal of Politics 63 (4): 1141-1162.

Heinz, John P., Edward O. Laumann, Robert H. Salisbury, and Robert L. Nelson. 1990. "Inner Circles or Hollow Cores? Elite Networks in National Policy Systems." The Journal of Politics 52 (2): 356-390.

Hicks, Raymond, Helen V. Milner, and Dustin Tingley. 2014. "Trade Policy, Economic Interests, and Party Politics in a Developing Country: The Political Economy of CAFTADR.” International Studies Quarterly 58: 106-117.

Hillman, Arye L., Kfir Metsuyanim, and Niklas Potrafke. 2015. "Democracy with Group Identity." European Journal of Political Economy 40: 274-287.

Hisnanick, John J., and Annette L. Rogers. 2006. "Household Income Inequality Measures Based on the ACS Data: 2000-2005." Working Paper, Program Participation and Income Transfers Branch Housing and Household Economic Statistics Division, U.S. Census Bureau.

Hogenboom, Barbara, and Alex E. Fernández Jilberto. 2012. "Neo-liberalism, Big Business and the Evolution of Interest Group Activity in Latin America." Journal of Public Affairs 14 (3): 283-295.

Hrebenar, Ronald J. 2004. "Japan." In Research Guide to U.S. and International Interest Groups, ed. Clive S. Thomas. Westport, CT: Praeger, 317-319.

Huckfeldt Robert, and John Sprague. 1993. "Citizens, Contexts, and Politics." In A.W. Finifter (Ed.), Political Science: The State of the Discipline. Washington DC: American Political Science Association.

Ibarra, Herminia. 1995. "Race, Opportunity, and Diversity of Social Circles in Managerial Networks." The Academy of Management Journal 38 (3): 673-703.

Jacek, Henry J. 2004. "Canada.” In Research Guide to U.S. and International Interest Groups, ed. Clive S. Thomas. Westport, CT: Praeger, 314-315.

Jarosz, Lucy and Victoria Lawson. 2002. “'Sophisticated People Versus Rednecks': Economic 
Restructuring and Class Difference in America's West." Antipode 34 (1): 8-27.

Jaumotte, Florence, Subir Lall, and Chris Papageorgiou. 2013. "Rising Income Inequality:

Technology, or Trade and Financial Globalization?" IMF Economic Review 61 (2): 271309.

Jenkins, Craig, and Charles Perrow. 1977. "Insurgency of the Powerless: Farm Worker Movements." American Sociological Review 42 (2): 249-268.

Jones, Jeffrey M. 2017. "Worry About Hunger, Homelessness Up for Lower-Income in US." Gallup. http://www.gallup.com/poll/207521/worry-hunger-homelessness-lowerincome.apex

Kahn, Shamus Rahman. 2012. "The Sociology of Elites.” Annual Review of Sociology 38: 361-377.

Kapsos, Steven and Evangelia Bourmpoula. 2013. "Employment and Economic Class in the Developing World.” ILO Research Paper No. 6. International Labor Office.

Kenny, Christopher B. 1992. "Political Participation and Effects from the Social Environment." American Journal of Political Science 36 (1): 259-267.

Klandermans, Bert and Dirk Oegema. 1987. "Potentials, Networks, Motivations, and Barriers: Steps Towards Participation in Social Movements." American Sociological Review 52 (4): 519-531.

Knoke, David. 1990. "Networks of Political Action: Toward Theory Construction." Social Forces 68 (4): 1041-1063.

Kraul, Chris, “Can’t Buy Them Love,” Los Angeles Times, 05 July 2003.

Kurokawa, Yoshinori. 2011. "Variety-Skill Complementarity: A Simple Resolution of the Trade-Wage Inequality Anomaly." Economic Theory 46 (2): 297-325.

La Due Lake, Ronald, and Robert Huckfeldt. 1998. "Social Capital, Social Networks, and Political Participation.” Political Psychology 19 (3): 567-584.

Lareau, Annette. 1987. "Social Class Differences in Family-School Relationships: The Importance of Cultural Capital.” Sociological Education 60 (2): 73-85.

Lax, Jeffrey R. and Justin H. Phillips. 2012. "The Democratic Deficit in the States." American Journal of Political Science 56 (1): 148-166.

Lehman, Howard P. 2008. "The Emergence of Civil Society Organizations in South Africa." Journal of Public Affairs 8: 115-127.

Leighley, Jan E. 1990. "Social Interaction and Contextual Influences on Political Participation." 
American Politics Quarterly 18 (4): 459-75

Leighley, Jan and Jonathan Nagle. 1992. "Socioeconomic Class Bias in Turnout, 1964-1988: the Voters Remain the Same.” The American Political Science Review 86 (3): 725-736.

Lewis-Beck, Michael S., and Martin Paldam. 2000. "Economic Voting: An Introduction." Electoral Studies 19 (2-3): 113-121.

Lijphart, Arend. 1997. "Unequal Participation: Democracy’s Unresolved Dilemma." The American Political Science Review 91 (1): 1-14.

Lijphart, Arend. 1999. Patterns of Democracy: Government Forms and Performance in ThirtySix Countries. New Haven: Yale University Press.

Lim, Chaeyoon. 2008. "Social Networks and Political: Participation: How Do Networks Matter?" Social Forces 87 (2): 961-982.

Lin, Nan. 1999. "Building a Network Theory of Social Capital.” Connections 22 (1): 28-51.

MacKuen, Michael B., Robert S. Erikson, and James A. Stimson. 1992. "Peasants or Bankers? The American Electorate and the U.S. Economy." The American Political Science Review 86(3): 597-611.

Madison, James. 1787. Federalist No. 10.

Mahler, Vincent A. 2008. "Electoral Turnout and Income Redistribution by the State: A CrossNational Analysis of the Developed Democracies." European Journal of Political Research 47: 161-183.

Malcolm, Michael. 2017. "Do Local Exports Impact Congressional Voting on Free Trade Agreements?" Economic Letters 154: 31-34.

Mansfield, Edward D. and Helen V. Milner. 2012. Votes, Vetoes, and the Political Economy of International Trade Agreements. Princeton: Princeton University Press.

Manzetti, Luigi. And Charles H. Blake. 1996. "Market Reforms and Corruption in Latin America: New Means for Old Ways." Review of International Political Economic 3 (4): 662-697.

Martins, Pedro S. and Pedro T. Pereira. 2004. "Does Education Reduce Wage Inequality? Quantile Regression Evidence from 16 Countries.” Labour Economics 11: 355-371.

Mayer, Wolfgang. 1984. "Endogenous Tariff Formation." The American Economic Review 74 (5): 970-985.

Mayda, Anna M. and Dani Rodrik. 2005. "Why are Some People (and Countries) more Protectionist than Others?" European Economic Review 49: 1393-1430. 
Mayhew, David R. 2004. Congress: The Electoral Connection. 2nd Ed. New Haven, CT: Yale University Press.

McClurg, Scott D. 2003. "Social Networks and Political Participation: The Role of Social Interaction in Explaining Political Participation." Political Research Quarterly 56 (4): 449-464.

McClurg, Scott D. 2006. “The Electoral Relevance of Political Talk: Examining Disagreement and Expertise Effects in Social Networks on Political Participation." American Journal of Political Science 50 (3): 737-754.

McGrath, Conor. 2008. "The Development and Regulation of Lobbying in the New Member States of the European Union.” Journal of Public Affairs 8: 15-32.

Milanovic, Branko. 2012. "Global Inequality Recalculated and Updated: The Effect of new PPP Estimates on Global Inequality and 2005 Estimates." The Journal of Economic Inequality 10 (1): 1-18.

Milner, Helen V. 1999. “The Political Economy of International Trade.” Annual Review of Political Science 2: 91-114.

Milner, Helen V., and Keiko Kubota. 2005. "Why the Move to Free Trade? Democracy and Trade Policy in the Developing Countries." International Organization 59 (1): 107-143.

Moore, Gwen. 1979. "The Structure of a National Elite Network." American Sociological Review 44 (5): 673-692.

Moravcsik, Andrew. 1997. "Taking Preferences Seriously: A Liberal Theory of International Politics." International Organization 51 (4): 513-553.

Morris, Stephen D. 2008. "Editor's Note: Corruption in Latin America." The Latin Americanist 49 (2): 5-16.

Muir, Donal E. and Eugene A. Weinstein. 1962. "The Social Debt: An Investigation of LowerClass and Middle-Class Norms of Social Obligation." American Sociological Review 27 (4): 532-539.

Mutz, Diana C. 2002. "The Consequences of Cross-Cutting Networks for Political Participation.” American Journal of Political Science 46 (4): 838-855.

Nelsen, Brent F. 2004. "The Nordic Countries.” In Research Guide to U.S. and International Interest Groups, ed. Clive S. Thomas. Westport, CT: Praeger, 311-314.

Newport, Frank. 2015, March 2. “American Continue to Say U.S. Wealth Distribution is Unfair." Gallup. Retrieved from http://www.gallup.com/, 
Nir, Lilach. 2011. "Disagreement and Opposition in Social Networks: Does Disagreement Discourage Turnout?” Political Studies 59: 674-692.

Noenes, Anthony J., Frank R. Baumgartner, and Beth L. Leech. 2004. “The Interest Group Universe in Washington, D.C., and the States." In Research Guide to U.S. and

International Interest Groups, ed. Clive S. Thomas. Westport, CT: Praeger, 118-122.

Norton, Philip, ed. 1999. Parliaments and Pressure Groups in Western Europe. London: Frank Cass.

Olson, Mancur. 1965. The Logic of Collection Action: Public Goods and the Theory of Groups. Cambridge, MA: Harvard University Press.

O’Rourke, Kevin H., Richard Sinnott, J. David Richardson, and Dani Rodrik. 2001. “The Determinants of Individual Trade Policy Preferences: International Survey Evidence.” Brookings Trade Forum 157-206.

Ostrower, Francie. 1995. Why the Wealthy Give. Princeton: Princeton University Press.

Passy, Florence, and Marco Giugni. 2001. "Social Networks and Individual Perceptions: Explaining Differential Participation in Social Movements." Sociological Forum 16 (1): 123-153.

Prior, Markus. 2005. "News vs. Entertainment: How Increasing Media Choice Widens Gaps in Political Knowledge and Turnout.” American Journal of Political Science 49(3): 577-92.

Puga, Diego. 1999. "The Rise and Fall of Regional Inequalities.” European Economic Review 43: 303-334.

Putnam, Robert D. 2000. Bowling Alone. New York: Simon \& Schuster.

Putnam, Robert D. 1988. "Diplomacy and Domestic Politics: The Logic of Two-Level Games." International Organization 43 (3): 427-460.

Reed, John Shelton, "North Carolina and the Politics of Barbecue," New York Times, 14 March, 2016.

Richey, S. 2008. "The Autoregressive Influence of Social Network Political Knowledge on Voting Behaviour." British Journal of Political Science 38 (3): 527-42.

Rigby, Elizabeth, and Gerald C. Wright. 2013. "Political Parties and Representation of the Poor in the American States." American Journal of Political Science 57 (3): 552-565.

Robertson, Raymond. 2000. "Trade Liberalisation and Wage Inequality: Lessons from the Mexican Experience." The World Economy 23 (6): 827-859. 
Rosenstone, Seven J., John Mark Hansen. 1993. Mobilization, Participation, and Democracy in America. Macmillan Publishing Company: New York.

Schattschneider, E. E. 1960. The Semisovereign People: A Realist's View of Democracy in America. Boston: Wadsworth.

Scheufele, Dietram A. Matthew C. Nisbet, Dominique Brossard, and Erik C Nisbet. 2004. "Social Structure and Citizenship: Examining the Impacts of Social Setting, Network Heterogeneity, and Informational Variables on Political Participation." Political Communication 21: 315-338.

Shukla, Anshuman. 2015. "That Which Shall Not be Named: Questioning the Taboo of Lobbying in the Indian Policy: A prologue to Public Sphere Reforms." Journal of Law and Social Sciences 4 (2): 12-20.

Solt, Frederick. 2008. "Economic Inequality and Democratic Political Engagement." American Journal of Political Science 52 (1): 48-60.

Solt, Frederick. 2016. "The Standardized World Income Inequality Database.” Social Science Quarterly 97. SWIID Version 6.2, March 2018.

Steinfield, Charles, Nicole B. Ellison, Cliff Lampe. 2008. "Social Capital, Self-Esteem, and use of Online Social Network Sites: A Longitudinal Analysis.” Journal of Applied Developmental Psychology 29: 434-445.

Steven Ruggles, Katie Genadek, Ronald Goeken, Josiah Grover, and Matthew Sobek. Integrated Public Use Microdata Series: Version 6.0 [Machine-readable database]. Minneapolis: University of Minnesota, 2015.

Stolper, Wolfgang F., and Paul A. Samuelson. 1941. "Protection and Real Wages." The Review of Economic Studies 9 (1): 58-73.

Strolovitch, Dara Z. 2007. Affirmative Advocacy: Race, Class, and Gender in Interest Group Politics. Chicago: University of Chicago Press.

Stroud, Natalie Jomini. 2008. "Media Use and Political Predispositions: Revisiting the Concept of Selective Exposure.” Political Behavior 30 (3): 341-366.

Sudulich, Maria Laura, Matthew Wall, and David M. Farrell. 2013. "Why Bother Campaigning? Campaign Effectiveness in the 2009 European Parliament Elections." Electoral Studies 32 (4): 768-778.

Thomas, Clive S. 2004. "The "Recent Discovery" of Interest Groups." In Research Guide to U.S. and International Interest Groups, ed. Clive S. Thomas. Westport, CT: Praeger, 299-301. 
Thomas, Clive S., and Ronald J. Hrebenar. 2008. "Understanding Interest Groups, Lobbying and Lobbyists in Developing Democracies." Journal of Public Affairs 8: 1-14.

Thomas, Clive S. 2009. "Understanding the Development and Operation of Latin American Interests, Power Groups and Interest Groups." In Interest Groups and Lobbying in Latin America, Africa, the Middle East, and Asia, Conor McGrath (ed.). Lewiston-QueenstonLampeter: The Edwin Mellen Press. 3-30.

Thomas, Clive S., and Kristina Klimovich. 2014. "Interest Groups and Lobbying in Latin America: Theoretical and Practical Considerations." Journal of Public Affairs 14 (3): $165-182$.

Trefler, John. 1993. "Trade Liberalization and the Theory of Endogenous Protection: An Econometric Study of U.S. Import Policy.” Journal of Political Economy 101 (1): 138160.

U.S. Census Bureau (2017). American Community Survey. https://factfinder.census.gov/faces/nav/jsf/pages/download_center.xhtml

U.S. Senate: Select Committee on Presidential Campaign Activities. 2017. "Treaties." Retrieved July 3, 2018, from https://www.senate.gov/artandhistory/history/common/briefing/Treaties.htm

Useem, Michael, and Jerome Karabel. 1986. "Pathways to Top Corporate Management." American Sociological Review 51 (2): 184-200.

Verba, Sidney, Kay Lehman Schlozman, Henry Brady, and Norman H. Nie. 1993. "Race, Ethnicity and Political Resources: Participation in the United States. British Journal of Political Science 23 (4): 453-497.

Verba, Sidney, Kay Lehman Schlozman, and Henry Brady. 1995. Voice and Equality. Harvard University Press: Cambridge.

Warhurst, John. 2004. "Australia and New Zealand." In Research Guide to U.S. and International Interest Groups, ed. Clive S. Thomas. Westport, CT: Praeger, 315-316.

World Bank. 2016. World Development Indicators. Washington, D.C.: The World Bank. http://data.worldbank.org/data-catalog/world-development-indicators

Wellman, Barry, Anabel Quan Haase, James Witte, and Keith Hampton. 2001. "Does the Internet Increase, Decrease or Supplement Social Capital?" The American Behavioral Scientist 45 (3): 436-455.

Whitten, Guy D., and Harvey D. Palmer. "Cross-national Analyses of Economic Voting." Electoral Studies 18: 49-67. 
Winters, Jeffrey A. and Benjamin I. Page. 2009. "Oligarch in the United States.” Perspectives on Politics 7 (4): 731-751.

Winters, Jeffrey A. 2011. Oligarchy. New York: Cambridge University Press.

Wood, Adrian. 1997. "Openness and Wage Inequality in Developing Countries: The Latin American Challenge to East Asian Conventional Wisdom." The World Bank Economic Review 11 (1): 33-57.

World Trade Organization. 2016. Regional Trade Agreement Database. http://rtais.wto.org/UI/PublicMaintainRTAHome.aspx

World Trade Organization: Members and Observers. 2018. Retrieved from https://www.wto.org/english/thewto_e/whatis_e/tif_e/org6_e.htm.

Wright, Erik Olin. 1978. "Race, Class, and Income Inequality." American Journal of Sociology 83 (6): 1978. 